Portland State University

PDXScholar

1987

\title{
Explosion structures in Grande Ronde basalt of the Columbia Riverbasalt group, near Troy, Oregon
}

Leonard Lee Orzol

Portland State University

Follow this and additional works at: https://pdxscholar.library.pdx.edu/open_access_etds

Part of the Geology Commons, and the Volcanology Commons Let us know how access to this document benefits you.

\section{Recommended Citation}

Orzol, Leonard Lee, "Explosion structures in Grande Ronde basalt of the Columbia Riverbasalt group, near Troy, Oregon" (1987). Dissertations and Theses. Paper 3750.

https://doi.org/10.15760/etd.5634

This Thesis is brought to you for free and open access. It has been accepted for inclusion in Dissertations and Theses by an authorized administrator of PDXScholar. Please contact us if we can make this document more accessible: pdxscholar@pdx.edu. 
AN ABSTRAST OF THE THESIS OF Leonard Lee Orzol for the Master of Science in Geology presented June 12, 1987.

Title: Explosion Structures in Grande Ronde Basalt of the Columbia River Basalt Group, near Troy, Oregon.

APPROVED BY MEMBERS OF THE THESIS COMMITEE:
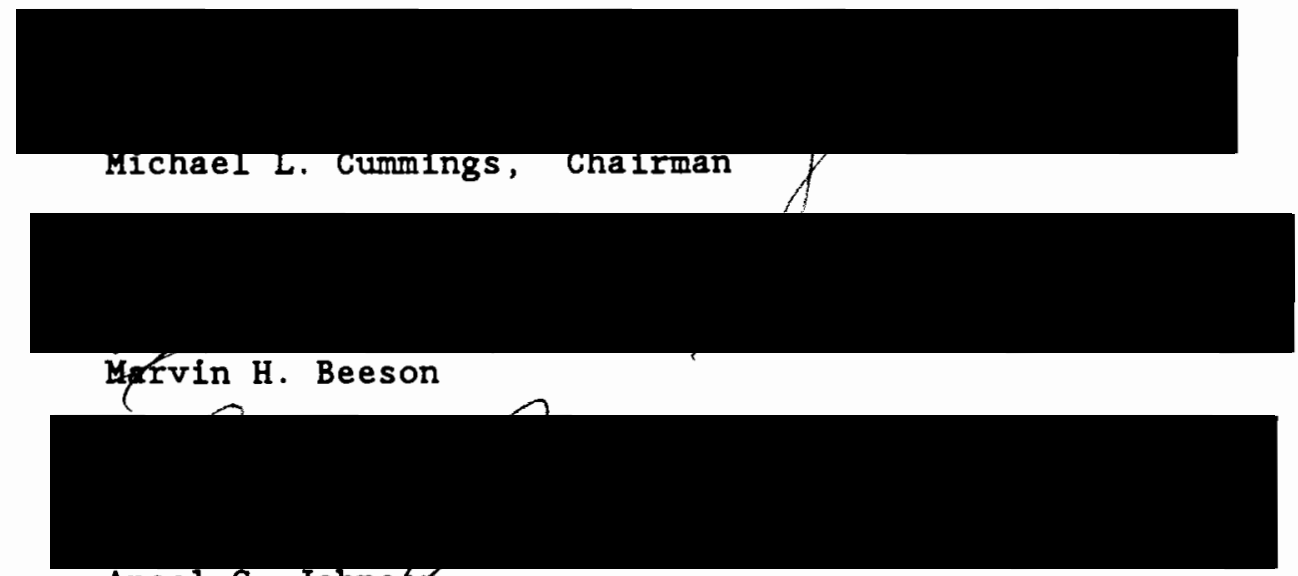

Ansel G. Johnson

Explosion structures occur in flows of Grande Ronde Basalt in the study area near Troy, oregon. Data from nineteen stratigraphic sites indicate that the maximum number of flows that contain explosion structures at any one site is six. In the informally named Troy flow, explosion structures are widespread.

Each flow that contains explosion structures can be divided into two cooling units. The first cooling units occupy troughs in the pre-eruption topography and are up to 10 meters thick. The second cooling units contain the explosion structures and are up to 100 meters thick. The thickness of flows that contain explosion 
structures range from 10 meters to 150 meters. A plot of the thickness of an explosion structure against the total thickness of the flow is linear with slope of approximately 0.5 . The breccias within explosion structures average 428 of the total thickness of a flow.

The overall shape of an explosion structures is similar to a three-dimensional nested arch with a central spine of breccia that cuts through the uppermost arches. Jointing patterns follow the shape of the arches. The linear trends of the central spines within explosion structures of the Troy flow parallel either the northeasttrending Grande Ronde (N $3^{\circ}$ E) fault system or the northwest-trending dike system in the area $\left(\mathrm{N} 15^{\circ} \mathrm{W}\right)$.

Two processes operate during the formation of explosion structures 1) mixing and 2) fragmentation. These two processes produce unique intraflow zones within the second cooling unit. Petrographic textures of these intraflow zones range from vitrophyric to intersertal to intergranular. All three textures can be observed in thin bands or layers in samples from the upper intraflow zones of the second cooling units. Individual bands or layers are twisted, pinched, and swirled due to mixing.

Fragmentation and mixing produce a vertically stratified central spine composed of three main types of clasts: vesicular to nonvesicular, scoriaceous, and pahoehoe types. Clast sizes range from lapilli in the outer matrix-supported margin to block in the inner clast-supported core.

Broad overall trends occur in geochemical data for the Troy 
flow and a flow stratigraphically above the Troy flow.

Concentrations of particular elements increase or decrease in samples towards the base of the flow relative to the uppermost sample. K, La, Eu, and Ta are enriched and Fe and Co depleted greater than 10 towards the base of a flow in areas away from explosion structures. Particular elements are enriched ( $\mathrm{Ce}, \mathrm{Hf}$ ) or depleted (Th) less than 108 towards the base. There explosions structures are present within the flow, these broad overall trends are less pronounced and few elements display these trends of enrichment or depletion. 
EXPLOSION STRUCTURES IN GRANDE RONDE BASALT OF THE COLUMBIA RIVER BASALT GROUP, NEAR TROY, OREGON.

by

LEONARD LEE ORZOL

A thesis submitted in partial fulfillment of the requirements for the degree of

\author{
MASTER OF SCIENCE \\ in \\ GEOLOGY
}

Portland State University

1987 
TO THE OFFICE OF GRADUATE STUDIES AND RESEARCH:

The members of the Committee approve the thesis of Leonard Lee Orzol presented June 12, 1987.

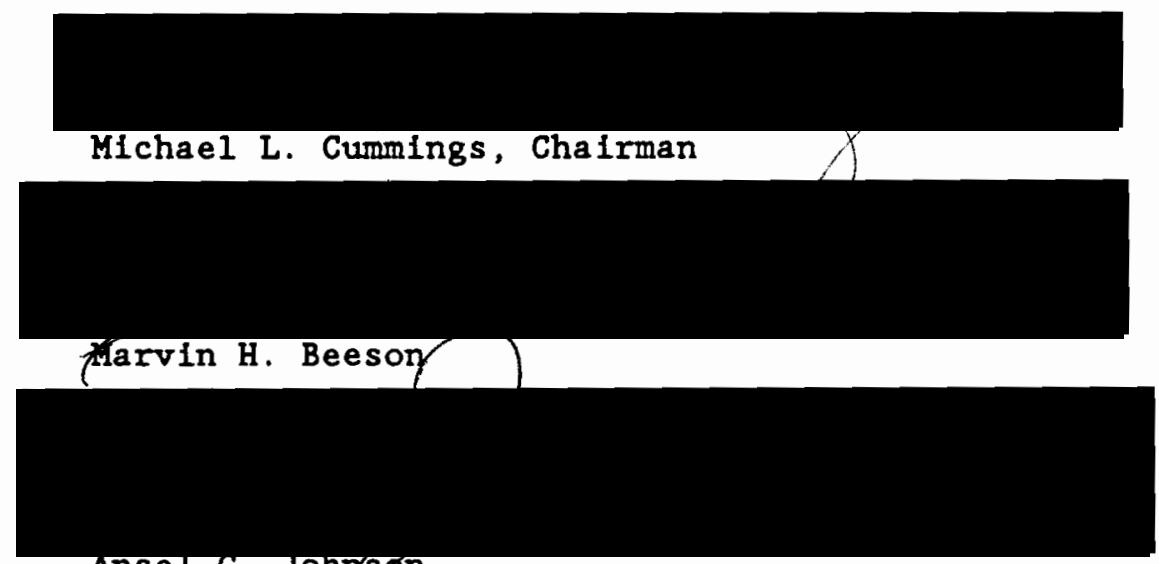

Anse1 G. Jonżson

\section{APPROVED :}

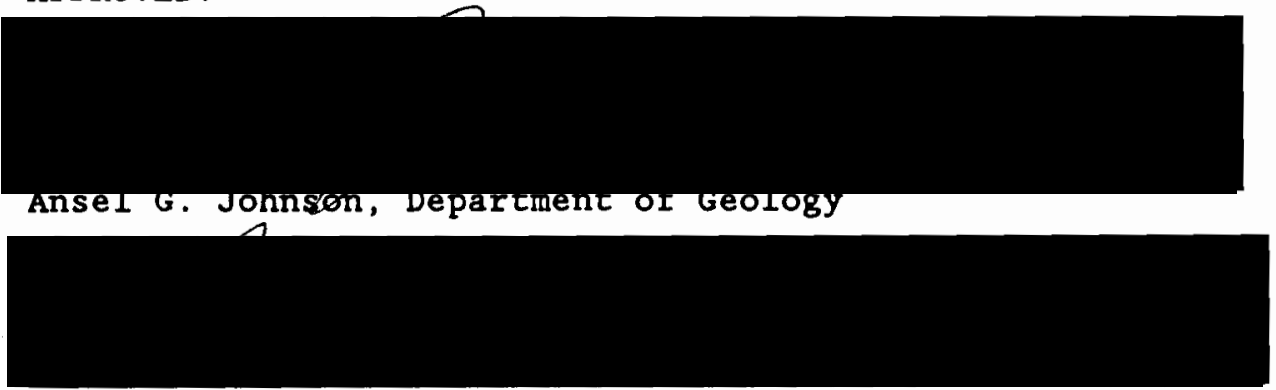

Bernard Ross, Vice Provost for Graduate Studies 


\section{ACKNOWLEDGEMENTS}

I would like to thank Lisa, my wife, for her patience and support and especially for her helpful editing of this thesis. My gratitude is extended to Michael Cummings, my advisor, for his contributions during the research and subsequent writing of my thesis. Thanks also goes to the remaining members of my committee, Marvin Beeson and Ansel Johnson, for their insight and direction. Donald Howard's research was very helpful in the determination of the iron oxidation states of my rock samples. I thank Terry Tolan for the thin sections of my rock samples. I appreciate the support from my friends and faculty at Portland State University and from my friends outside the university, and the U.S. Geological Survey. Finally, I wish to acknowledge the Orzol and Rosenthal families for their loving support. 
TABLE OF CONTENTS

PAGE

ACKNOWLEDGEMENTS . . . . . . . . . . . . . . . . . . . . .

LIST OF TABLES . . . . . . . . . . . . . . . . . . . . . . . iv

LIST OF FIGURES . . . . . . . . . . . . . . . . . . . . . $x$

CHAPTER

I INTRODUCTION . . . . . . . . . . . . . . . . . . . 1

Scope and Products . . . . . . . . . . . . . . . 2

Location and setting . . . . . . . . . . . 5

Nomenclature... . . . . . . . . . . . . . . . 5

Methods . . . . . . . . . . . . . . . . . 7

II PREVIOUS INVESTIGATIONS . . . . . . . . . . . . . 11

III STRATIGRAPHY AND PETROGRAPHY . . . . . . . . . . . 15

Geochemistry . . . . . . . . . . . . . . . 48

INAA

Mossbauer

XRF

IV DISCUSSION . . . . . . . . . . . . . . . . . 70

CONCLUSION . . . . . . . . . . . . . . . . . . . 104

REFERENCES CITED . . . . . . . . . . . . . . . . . 107

APPENDIX A: SUMMARY OF STRATIGRAPHIC AND

SAMPLE INFORMATION . . . . . . . . . . . . . . . . 115

APPENDIX B: SUMMARY OF PETROGRAPHIC

INFORMATION . . . . . . . . . . . . . . . . . 146

APPENDIX C: SUMMARY OF TRAVERSE INFORMATION . . . . . . . 179 
PAGE

APPENDIX D: SUMMARY OF GEOCHEMICAL INFORMATION . . . . . . 192 APPENDIX E : DEFINITIONS . . . . . . . . . . . . . . . . . 214 APPENDIX F: SUMMARY OF FIELD AND LABORATORY TECHNIQUES . . . . . . . . . . . . . . . . . . . . 216 APPENDIX G: SUMMARY OF STATISTICAL ANALYSIS OF GEOCHEMICAL DATA . . . . . . . . . . . . . . . 219 


\section{LIST OF TABLES}

TABLE

PAGE

I Summary of locations, map symbols, flow

types for each stratigraphic section . . . . .

II Thicknesses of the breccia top and

compact intervals for brecciated flows

at various locations . . . . . . . . . . . .

III Summary of field and petrographic

characteristics for the intrazones

within the first cooling unit . . . . . . .

IV Summary of field and petrographic

characteristics for the intraflow

zones within the second cooling unit . . . .

$\mathrm{V}$ Summary of percentages for clast types

encounter during counting traverses . . . . .

VI Summary of sample locations and sample

laboratory analytical methods . . . . . . .

VII Equivalent samples comparing relative

$$
\text { positions within a flow . . . . . . . . . }
$$

VIII Summary of enriched or depleted elements

for sample sets . . . . . . . . . . . . . . .

IX INAA concentrations, equivalent depths, depth in flow, elevation of samples from sample set Squaw Canyon \#l (SC\#1) . . . . 
$\mathrm{X}$ INAA concentrations, equivalent depths, depth in flow, elevation of samples from sample set Wenaha.B . . . . . . . . . .

XI Summary of the elements which changed across the interface from the special split sample to the immediate subjacent samples . . . . . . . . . . . . .

XII XRF data for certain elements . . . . . . . . .

XIII Summary of locations, map symbols, flow

types for each stratigraphic section . . . . .

XIV Definitions for symbols used in stratigraphic sections . . . . . . . . . . . .

XV Definitions of terms used for groundmass

terms . . . . . . . . . . . . . . . . .

XVI Definitions used for phenocrysts and microphenocrysts . . . . . . . . . . .

XVII Definitions of terms used for vesicles.......

XVIII Symbols and definitions for adjectives used . . . . . . . . . . . . . . . .

XIX-XLVI Thin section description for sample :

$M-8-21 \# 5 C$. . . . . . . . . . . . .

XLVII Definitions and symbols for horizontal

and vertical traverses . . . . . . . . . . .

XLVIII Horitzontal grid traverse 1 through

explosion structures 
XLIX Horitzontal traverse 2 through explosion structures . . . . . . . . . . . . .

L Horitzontal traverse 3 through explosion structures . . . . . . . . . . . .

LI Horitzontal traverse 4 through explosion structures . . . . . . . . . . . . .

LII Descriptions for clast types used during counting traverses . . . . . . . . . . . . .

LIII Clast counting grid for horitzontal

traverse 2 through a central spine . . . . .

LIV Horitzontal traverse 5 clast grid counting

through a steeply dipping breccia zone . . . .

LV Horitzontal line counting traverses 6 and 7

in a central spine . . . . . . . . . . . . .

LVI Horizontal grid traverse 8 through an

explosion structure. . . . . . . . . . . . .

LVII Vertical line traverse 9 through an

explosion structure... . . . . . . . . . .

LVIII Summary of breccia trends and locations . . . . . 190

LIX Summary of sample locations and sample

laboratory analytical methods . . . . . . . .

LX-LXV INAA values, equivalent depths, depth in flow,

elevation of samples fron sample set

ELLOIT FARM (EF) - WENAH RAVINE (WR) . . . 
LXVI INNA data from 1st count for certain

ELements followed by its error . . . . . . . 206

LXVII INNA data from 2nd count for certain

ELements followed by its error . . . . . . 209

LXVIII XRF data for certain elements . . . . . . . . . 213

LXIX Detailed summary of field techniques

and equipment... . . . . . . . . . . . 217

LXX Detailed summary of laboratory techniques

and equipment... . . . . . . . . . . . 218

LXXI Individual variances for each element . . . . . 220 
1. Generalized schematic of a brecclated flow showing a brecciated flow area and an explosion structure . . . . . . . . . . . . . .

2. Location map for the study area showing its relation to the states of Oregon and Washington . . . . . . . . . . . . . . . . . .

3. Generalized schematic showing the relationships between different flow areas within a single hypothetical flow . . . . . . . . . . . . . . . . . . .

4. The stratigraphy of the study area as determined by Ross (1978)

5. A map showing the maximum number of brecclated flows observed at locations within the study area

6. A graph showing the individual breccia

intervals plotted against the total thickness of that flow . . . . . . . . . . . . . 20

7. A map showing the trends of the central spine for brecclated flows . . . . . . . . . . . 
8. Generalized schmetic of a brecclated flow area

showing two cooling units . . . . . . . . . . . . 24

9. Samples from the chilled pahoehoe base of

the first and second cooling units of a

brecciated flow area of the Troy flow . . . . . . 26

10. Generalized schematic of the first cooling

unit parallel to the plane of the

central spine . . . . . . . . . . . . . . . . .

11. Generalized schematic of the second

cooling unit viewed perpendicular to the

plane of the central spine . . . . . . . . . . .

12. A vesicular sample of the base from

a non-brecciated flow area that shows a rough surface texture . . . . . . . . . . . . .

13. Samples from the confining walls zone

showing the ripple-1ike marks along the joint traces . . . . . . . . . . . . . . . . . .

14. A single plate composed of welded

$$
\text { fragments (the dark colored basalt) }
$$

15. A scoriaceous clast observed within

confining walls near the apex that

includes several less distinct

vesicular clasts . . . . . . . . . . . . . . . 
16. Petrographic textures in a sample from a basaltic arm that shows the twisting, pinching, swelling, and swirling of the individual bands or layers . . . . . . . . . . . . 40

17. Petrographic textures showing the reddish-colored intergranular bands and the black-colored vitrophyric to intersertal bands . . . . . . . . . . . . . . . .

18. Two samples from a trapped body of breccla . . . . . . . . . . . . . . . . . . .

19. Two samples from the confining walls of an explosion structure showing differnt colored layer of basalt . . . . . . . . .

20. A transition to larger diameter clasts

occur from the outer matrix-supported

breccia (left side) to the inner clast-

supported breccia (right side)

21. An assortment of three major clast types:

pahoehoe clast ( 6 ), scoriaceous clasts $(2,3)$, vesicular BVA $(1)$, and nonvesicular BVA $(4,5)$ 
22. Concentration trends in unbrecciated flow

areas for $\mathrm{La}, \mathrm{Ce}$, and $\mathrm{Sm}$ for sample

location site Elloit Farm showing

enrichment towards the base of the Troy

flow . . . . . . . . . . . . . . . . .

23. Concentration trends in brecciated flow

areas for $\mathrm{La}, \mathrm{Ce}$, and $\mathrm{Sm}$ for a sample

set from Wenaha Ravine showing less

pronounced enrichment towards the base

of the Troy flow . . . . . . . . . . . . . . . .

24. Concentration trends in brecciated flow

areas of the Troy flow ( ) and a

younger Grande Ronde Basalt flow ( )

shows similar patterns towards the base

of each flow . . . . . . . . . . . . . . . . . .

25. Concentration trends in the sample set

from Squaw Canyon (SC\#1) showing the

discrepancy caused by the special

sample 8-22-SC\#2B

26. A schematic showing the sample locations

for sample set Squaw Canyon $(S C \# 1)$ in a

younger Grande Ronde Basalt flow . . . . . . . . 
27. A schematic showing the sample locations for sample set Wenaha.B in the Troy flow collected at the interface between the confining walls and a trapped body of breccia . . . . . . . . . . . . . . . . . .

28. Concentration trends for the sample set

Wenaha. B that show the discrepancy

caused by the spectal sample

8-22-T1ALR . . . . . . . . . . . . . . . . .

29. Mgo data from XRF analysis plotted

against percent $\mathrm{SiO}_{2}$ for selected

samples from brecclated to nonbrecclated

flow areas . . . . . . . . . . . . . . . . . . 68

30. The crust fractures and the release of

pressure initiates degassing (1) . . . . . . . . .

31. During the formation process, material is

moved upward by the release of

steam/water . . . . . . . . . . . . . . . .

32. An episodic event process starts with an

intense explosion that produces lapil1i

size fragments

33. A single event process increases in

intensity as during the initial

moments (1 to 2) . . . . . . . . . . . . . . . . . 
34. A schematic summarizing the logical sequence of explosion processes involved in fuel-cooltant reactions . . . . . . . . . . 100 35-53. Stratigraphic sections : Eden Bench (EB) -

Cougar Creek (C) . . . . . . . . . . . . .

54. The position of each transverse are shown relative to the intraflow zones of the second cooling unit of the Troy flow. . . . . . . 180

55. Mossbauer spectrum of sample 8-22-T1Al. . . . . . . . 203

56. Mossbauer spectrum of sample 8-22-T1A3. . . . . . . . 204

57. Mossbauer spectrum of sample 8-22-T1C. . . . . . . . 205 
CHAPTER I

\section{INTRODUCTION}

Hydrovolcanic activity ranges from relatively minor phreatic events to catastrophic eruptions like the 1982 eruption of E1 Chichon (Sheridan and Wohletz, 1983). Hydrovolcanism refers to volcanic phenomena produced by interaction of magma or magmatic heat with an external source of water, such as a body of surface water or an aquifer (Macdonald, 1972; Sheridan and Wohletz, 1983). Variables controlling explosions related to hydrovolcanic processes are poorly understood, because not all water-lava interactions result in explosive activity. Sheridan and Wohletz (1983) argue the degree of explosivity is controlled primarily by the mass ratio of water to melt or lava. High mass ratios are related to low-energy or explosion-free interactions such as those that result in pillow formation in surface water. Low mass ratios are related to explosive activity such as in the formation of maars by interaction of magma with aquifers. Buchanan (1974), Witte and others (1970), and Board and others $(1974 ; 1975)$ have modeled hydroexplosions by comparison to fuel-coolant interaction (FCI) to simulate natural explosive processes that occur in melts or magmas that range in composition from rhyolite to basalt.

Interaction between surface or subsurface water and basaltic 
lavas of the Miocene Columbia River Basalt Group (CRB) have produced several hydrovolcanic features. These features include palagonite breccias, pillow-palagonite breccias, pillowed lavas, pipe vesicles, vesicle pipes, peperites, vesicle trains, and spiracles. Earlier investigators such as Fuller (1931) and Waters (1960) argue that these hydrovolcanic features were produced during minor explosive events. This study investigates features in basalt flows of the CRB that resulted from explosive water-lava interaction.

This water-lava interaction produced a structure of steeply dipping breccia by a violent upward release of subjacent steam through the still molten lava (hereafter called an explosion structure). Typically these structures are approximately $40 \mathrm{~m}$ across and occupy the upper $1 / 3$ to $1 / 2$ of a flow (Figure 1). The explosion structures were investigated within Grande Ronde Basalt of the Columbia River Basalt Group in northeastern Oregon and southeastern Washington in the steep canyons of the Wenaha and Grande Ronde Rivers near Troy, Oregon (Figure 2). The objectives of this study are 1) to describe and characterize these hydrovolcanic features, and 2) to examine the mechanisms of development of the explosion structures.

SCOPE AND PRODUCTS

The following five main tasks were completed.

1) Map the distribution and determine the characteristics of explosion structures within flow units and within the stratigraphic section of Grande Ronde Basalt in the Troy area, Oregon (Figure 2). 


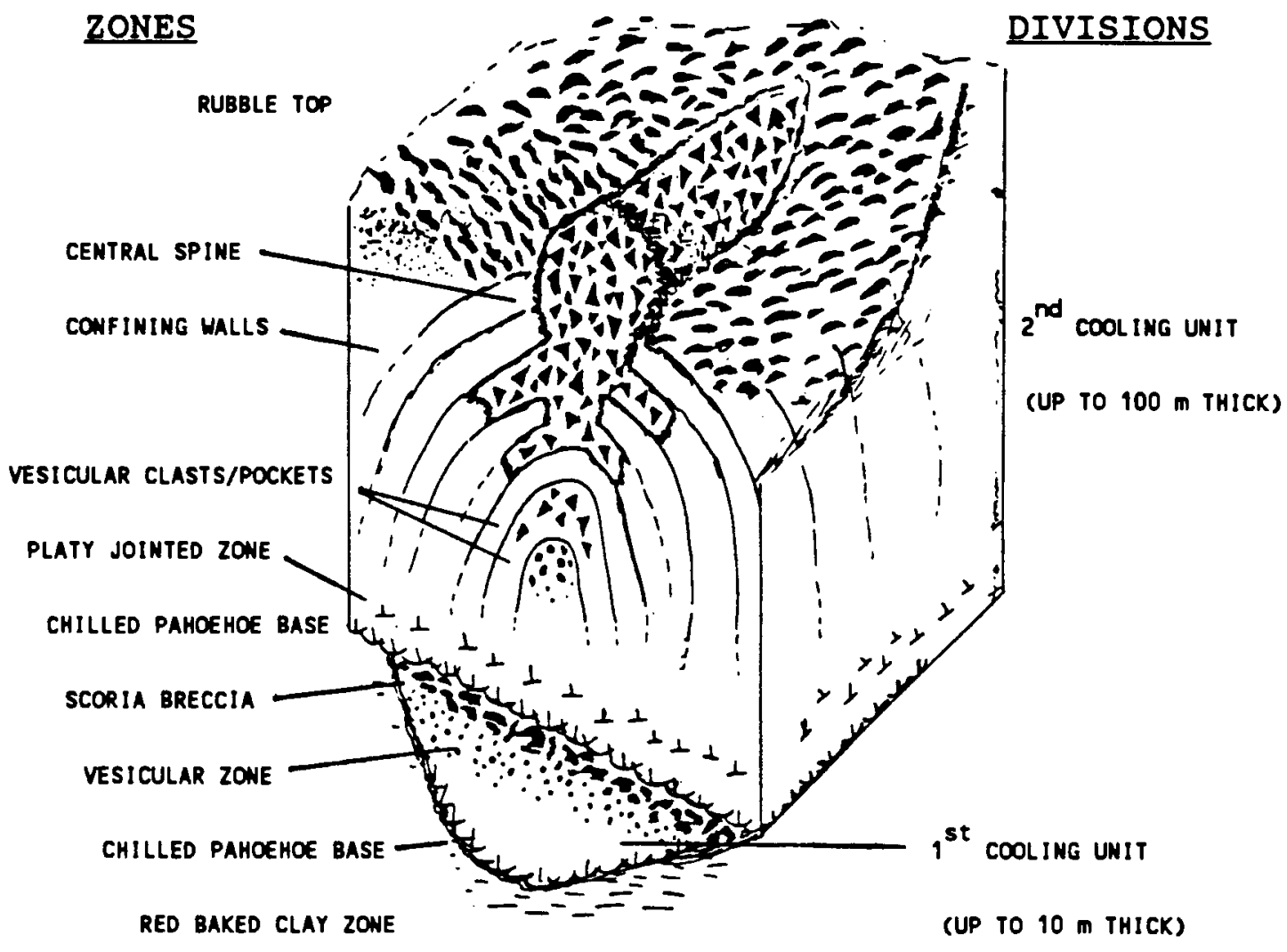

Figure 1. Generalized schematic of a brecciated flow showing a brecciated flow area and an explosion structure.

The study area covered portions of the Troy, Eden, and Flora $71 / 2$ minute quadrangles of Oregon and the Saddle Mountain, Mountain View, Diamond Peak, and Fields Spring $71 / 2$ minute quadrangles of Washington $(1: 24,00$ scale).

2) Determine the textures and fabrics produced during the formation of explosion structures.

3) Compare major and trace element geochemistry where explosion structures are present within the Troy flow and locations where the Troy flow is non-brecciated.

4) Determine iron oxidation states using Mossbauer 


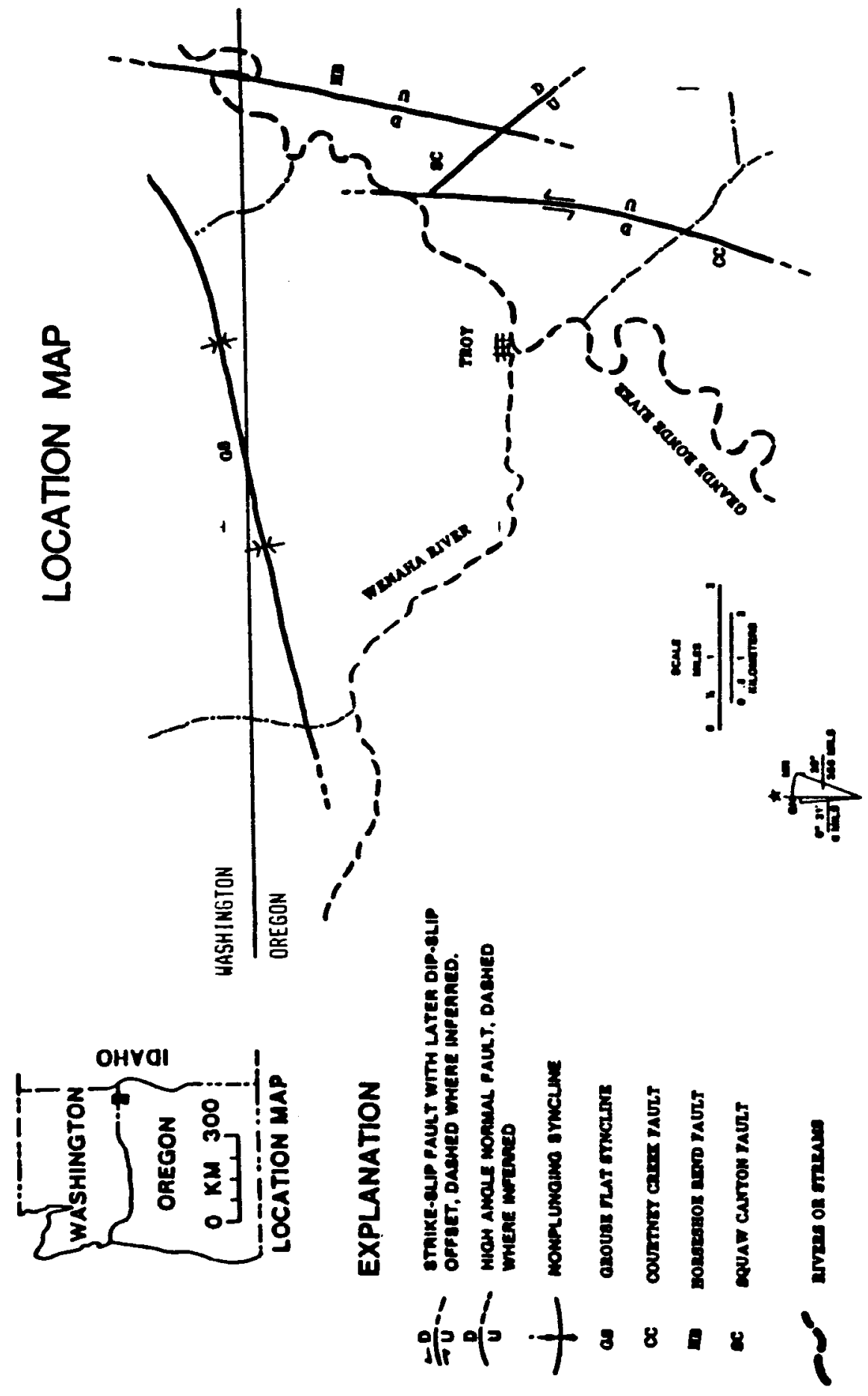

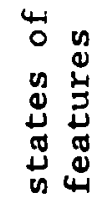

岳

운

ร

开 的

Ф

告是

$\infty \frac{1}{2}$

青势

起

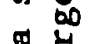

ஸे

* a

各选

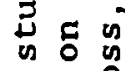

o 웅

过

곤

证岂

恖

E

넝

崩

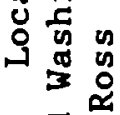

ㄱำ

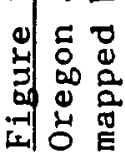


spectroscopy on samples from various textural zones within the structures.

5) Develop a model for the formation of the structures.

Products from this investigation are a geologic map of the study area that shows the distribution of the breccia structures within Grande Ronde Basalt, a model developed for the explosion structure formation in basaltic lava and the variables that constrain the behavior of the system.

\section{LOCATION AND SETTING}

The Grande Ronde and Wenaha Rivers have incised deep canyons into flows of the Columbia River Basalt Group and interflow sediments within the Grande Ronde River-Blue Mountain region of Oregon and Washington (Figure 2). The basalt flows are those of the Grande Ronde, Wanapum, and Saddle Mountains Basalts and interflow sediments are those of the Grouse Creek and Squaw Creek members of the Ellensburg Formation (Ross, 1978, 1980; Stoffe1 1981, 1984). The area of study centers on Troy, Oregon at the junction of the Wenaha and Grande Ronde Rivers (Figure 2). This study area encloses roughly six 7 1/2-minute quadrangles of northeast Oregon and southeast Washington and is approximately 200 square kilometers.

\section{NOMENCLATURE}

Several terms are used in this text and review of these terms will be helpful to the reader (see definitions in appendix $E$ ). The terms were developed to indicate a locality where explosion 
structures may or may not be present or to describe a particular type of clast found within the breccia of an explosion structure. Briefly, the Troy flow was singled out and named by Ross (1978) because of unusual lobes of dense basalt that penetrate into a thick flow-top breccia. These lobes form part of an explosion structure that occupies the upper $1 / 3$ to $1 / 2$ of a flow (Figure 1). A symmetrical collection of dense basalt lobes encloses a steeply dipping breccia in the center of an explosion structure and is called the confining walls. This steeply dipping breccia is called a central spine. An individual lobe is separated by a joint trace from the adjacent lobes and is called a basaltic arm. The confining walls form individual layers in the overall shape of an arch when viewed in cross-section perpendicular to the plane of the central spine (Figure 1).

A flow containing explosion structures is called a brecciated flow, whereas a flow lacking explosion structures is called a nonbrecciated flow. An explosion structure is formed by the interaction of water and basalt. The portions of a basalt flow containing explosion structures and the rocks immediately adjacent to an explosion structure within the same flow are called a brecciated flow area. Areas of basalt within a flow that contains explosion structures, but that are not immediately effected by the formation of explosion structures will be called unbrecciated flow areas. Areas of basalt within a flow that contain explosion structures but are not situated near explosion structures are called non-brecciated flow areas (Figure 3 ). 


\section{Scale $[\ldots \ldots \ldots \ldots .$.}

$1 / 4 \mathrm{~km}$

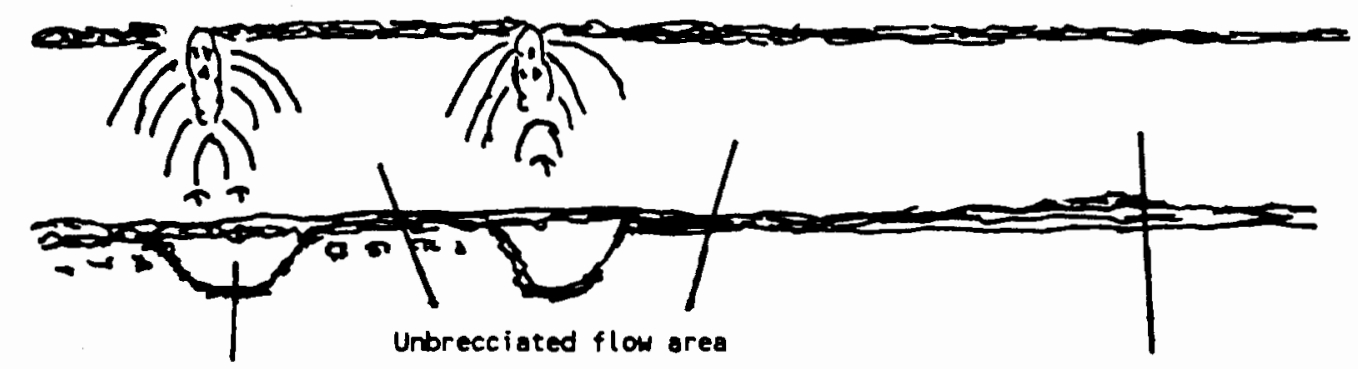

Brecciated flow area

Mon-brecciated flow area

Figure 3. Generalized schematic showing the relationships betwwen different flow areas within a single hyopethical flow. Brecciated flow areas are immediately affected by the process of formation, while unbrecciated to non-brecciated flow areas are not. Vertical features have been exaggerated approximately five times.

\section{METHODS}

\section{Field Studies}

All field work was conducted during a six-week period in the summer of 1985 and a one-week period during the fall of 1985.

Traverses were accomplished on foot and reconnaissance observations were conducted either by foot or from a truck. The following four tasks were accomplished:

1) Stratigraphic sections were measured at key localities along valley walls of the Wenaha and Grande Ronde Rivers near Troy, Oregon. Elevations of each flow were from readings using an M-1 altimeter. Stratigraphic sequence, thickness, and variations in textures within basalt flows that contained explosion structures were investigated. Thickness of various textural zones within each flow were noted or determined. The thickness of the portion containing steeply dipping breccias and the superjacent flow-top 
breccia within flows containing explosion structures were measured.

2) Samples of fresh basalt were collected from flows containing explosion structures for geochemical analysis. Data from geochemical analyses were used to infer formational processes of these structures.

3) The distribution of clast types, clast sizes, and widths of steeply dipping breccia zones were measured for flows with explosion structures by using either a 100 foot tape and/or a 2 foot by 2 foot square grid.

4) Trends of the central spines were measured. A search for fractures within the flows which underlie brecciated flow areas was made to determine whether the orientations of the central spines are related to such fractures.

A more detailed description of field techniques and equipment is presented in Appendix $F$.

\section{Laboratory Studies}

1) Fresh samples of basalt were analyzed by $x$-ray fluorescence (XRF) at Washington State University, Washington, instrumental neutron activation analysis (INAA) at Oregon State and Portland State Universities, and Mossbauer spectroscopy at Portland State University.

a) XRF was used to determine major oxide concentrations within various textural zones.

b) INAA was used to determine distribution of major and trace elements within explosion structures.

c) Mossbauer spectroscopy determined differences in 
oxidation states of iron within various textural zones produced during the formation of explosion structures and the iron-bearing oxide minerals present within these zones. Mossbauer spectroscopy and interpretation of the resulting spectrums were done by Donald L. Howard of Portland State University.

2) Petrogaphic analysis of various textural types within the flows determined the textural development of the samples and, in particular, features which indicate the dynamics of the processes by which explosion structures were developed.

A more detailed description of laboratory techniques and equipment is presented in Appendix F. 
CHAPTER II

\section{PREVIOUS INVESTIGATIONS}

The study area was mapped on a reconnaissance basis as part of a regional study by Russel (1897). Waters (1961) completed a stratigraphic section at the northern end of Powatka Ridge, south of the town of Troy, that was included in an early geochemical investigation of the stratigraphy of the Columbia River Basalt Group. Walker $(1973,1979)$ defined on a reconnaissance basis two major chemical types in the study area, the Yakima and Late Yakima chemical types. Swanson and others (1977) included portions of the study area in a regional reconnaissance map of southeastern Washington and adjacent Idaho.

Regional structural geology has been described by Ross (1975; 1978; 1980) (Figure 2) and Hooper and Camp (1981). An east-to-west regional tilting from isostatic rise of older rocks along the eastern margin of the Columbia Plateau, initiated before Miocene time, caused offlap of progressively younger basalt units. Faulting and folding through middle and late Miocene time occurred during a compressional stress regime with the primary compressive stress oriented in a northwest-southeast direction and reactivation of structural grain in the pre-Miocene basement. Within the study area, the Grande Ronde fault system, adjacent Grouse Flat syncline, 
and other structural features were produced during the compressional regime and a subsequent extensional period (Ross, 1978). Ross (1978) inferred that an initial subsidence of the Grouse Flat syncline, an initial uplift of the Saddle Butte anticline, and the subsequent strike-slip movement on the Grande Ronde fault system occurred during the compression regime and started before the Troy flow was erupted. Dip-slip movement on the Grande Ronde fault system developed during the extensional period and after the eruption of the Wenaha flow of the Saddle Mountains Basalt.

Ross (1978) mapped most of the study area at a scale of $1: 12000$ and determined the stratigraphy of the basalts in this area (Figure 4 modified with revisions by swanson and others 1979). The Troy flow of the Grande Ronde Basalt was informally named by Ross (1978). He described the Troy flow as a mappable unit that consistently was the thickest Grande Ronde Basalt flow exposed within the boundaries of his study area. At the best exposures of the Troy flow along the Wenaha River near the town of Troy, Ross (1978) measured a thickness of 84 meters and indicated thickening northward to 102 meters near Diamond Peak and thining southward from the Grande Ronde River.

Ross (1978) reported that at some localities, the Troy flow had an unusally thick flow-top breccla into which lobes of dense rock penetrate from below or occur as large isolated masses within the flow-top breccia. He sampled the Troy flow at localities where these unusual lobes or masses of dense rock were present and at other localities where these lobes were absent. The geochemical 


\begin{tabular}{|c|c|c|c|c|}
\hline \multicolumn{3}{|c|}{$\begin{array}{l}\text { Tright und } \\
\text { others. 1973 }\end{array}$} & \multirow{2}{*}{$\begin{array}{c}\begin{array}{c}\text { Centrel Portion of } \\
\text { Study Area }\end{array} \\
\text { Luford flow }\end{array}$} & \multirow{2}{*}{$\begin{array}{l}\begin{array}{c}\text { Southem Portion of } \\
\text { sewty Ares }\end{array} \\
\text { evfort now }\end{array}$} \\
\hline \multirow{15}{*}{ 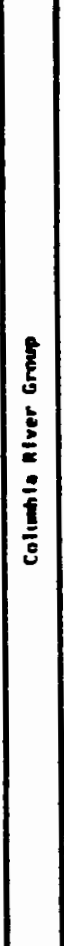 } & \multirow{14}{*}{ 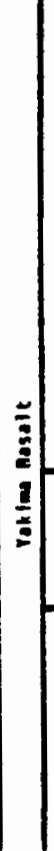 } & \multirow{7}{*}{ 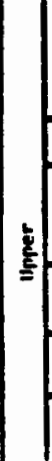 } & & \\
\hline & & & $\begin{array}{l}\text { Sediantary } \\
\text { Interbed }\end{array}$ & $\begin{array}{l}\text { Secimentury } \\
\text { Interter }\end{array}$ \\
\hline & & & Menthe Flow & Detuha Flow \\
\hline & & & $\begin{array}{l}\text { Groule }=5 \text { Ecen Flow } \\
\text { Enek } \\
\text { interpec }\end{array}$ & \multirow[t]{2}{*}{$\begin{array}{l}\text { Grouse Creek } \\
\text { Interbes" }\end{array}$} \\
\hline & & & Beer Croek Flow" & \\
\hline & & & tontilia flow & \multirow{2}{*}{$\begin{array}{l}\text { Uan:111. } \\
\text { Fion }\end{array}$} \\
\hline & & & & \\
\hline & & & Powtka flow. & Xuhn Ridge Flows" \\
\hline & & $\overline{\mathbf{x}}$ & Dodge Flow(s) & Dodge Flow (s) \\
\hline & & \multirow{5}{*}{ 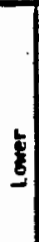 } & Undifferentia:ed & Undifferentiated \\
\hline & & & Troy flow & iroy flom \\
\hline & & & \multirow{3}{*}{ Undifferentfated } & Undifferontisesed \\
\hline & & & & ud Creve Flow \\
\hline & & & & Undifferentiated \\
\hline & & & $\begin{array}{l}\text { Inaha rasalt } \\
\text { exposed in study ares) }\end{array}$ & \\
\hline
\end{tabular}

Figure 4. The stratigraphy of the study area as determined by Ross (1978). Nomenclature has been revised by Swanson and others, (1979). The Troy flow occurs in the upper section of the Grande Ronde Basalt (Lower Yakima) followed by Wanapum Basalt (Middle Yakima) then Saddle Mountains Basalt (Upper Yakima). (after Ross, 1978)

data indicated that the Troy flow had the highest silica $\left(\mathrm{SiO}_{2}\right)$ concentration among the basalts within his study area with only 3 samples containing less than 548. Several other distinct chemical characteristics included low $\mathrm{MgO}$ and $\mathrm{CaO}$ and high $\mathrm{P}_{2} \mathrm{O}_{5}, \mathrm{~K}_{2} \mathrm{O}$, and $\mathrm{TiO}_{2}$ when compared to other Grande Ronde Basalts.

Features generated from interaction of water and flows of the Columbia River Basalt have been reported by many authors: Fuller 
(1931), Waters (1960), Schmincke (1967), Swanson (1967). These features include pillow bases of some flows (Fuller, 1931), pillowpalagonite breccia (Fuller, 1931), pipe vesicles (Waters, 1960), vesicle cylinders (Waters, 1960), and spiracles (Fuller, 1931; Waters, 1960; Swanson, 1967), and peperites (Fuller, 1931; Waters, 1955; Schmincke, 1967; Swanson, 1967). Al1 features except peperites are formed where surface flows trap pockets of air, gas from burnt vegetation, and steam expelled from soils and watersoaked sediments, or produced by advance of the flow into either relatively shallow or deep bodies of water (Fuller, 1931; Waters, 1960). Peperites, basalt-sediment breccias on the Columbia River Plateau, result from intrusion of fluid basaltic dikes and sills or burrowing of surface flows into moist, soft sediments (Schmincke, 1967).

Within the study area, Ross (1978) reported hyaloclastite deposits superjacent to the Troy flow at one stratigraphic location (Driveway Ridge secton) and subjacent at two locations (Bald Butte and Crooked Neck Creek sections). Typically these deposits are yellow brown to light gray in color, fine to coarse-grained, contain angular fragments, and are, in some localities, well-bedded. 
CHAPTER III

\section{STRATIGRAPHY AND PETROGRAPHY}

Stratigraphic sections in the study area were studied in order to examine the relation of regional scale features to the spatial distribution of explosion structures and the total number of flows that contain explosion structures (brecciated flows). The basalt flows in the study area are those of the Grande Ronde Basalt, Wanapum Basalt, and Saddle Mountains Basalt. Nineteen stratigraphic sections were measured at key locations (stratigraphic information is compiled in Appendix A, the site locations are shown on Plate 1 and the locations are listed in Table I). Stratigraphic locations were selected for exposure and location within the study area. Three types of measured sections were conducted. 1) Vertical sections were measured of all flows present at each stratigraphic site. 2) Partial vertical sections were measured for selected flows. 3) Lateral sections were measured to determine horizontal variations within a flow.

Results show explosion structures are only found within Grande Ronde Basalt and are not present in Wanapum and Saddle Mountains Basalt within the boundaries of this study area. The measuredsection sites contain one or more brecciated flows and the Troy flow is one of these brecciated flows (Table I). The maximum number of 
TABLE I

SUMMARY OF LOCATIONS, MAP SYMBOL, FLON TYPES FOR EACH STRATIGRAPHIC SECTION

\begin{tabular}{|c|c|c|c|c|c|c|}
\hline $\begin{array}{l}\text { Stratigraphic } \\
\text { site label }\end{array}$ & $\begin{array}{l}\text { ‡Map } \\
\text { symbol }\end{array}$ & $\begin{array}{l}\text { +Type } \\
\text { section }\end{array}$ & $\begin{array}{l}\text { STotal } \\
\text { Flows }\end{array}$ & $\begin{array}{c}\text { \&Troy } \\
\text { Brecciated }\end{array}$ & $\begin{array}{r}\text { Starting } \\
71 / 2 \text { minute }\end{array}$ & $\begin{array}{l}19 \text { Location } \\
\text { e quadrangles }\end{array}$ \\
\hline Eden Bench & EB & vc & 6 & $Y$ & $N E 1 / 4, N H 1 / 4$, SE $1 / 4$ & Sect 5 T5N R43E Troy \\
\hline Wenaha Camp & WC & $v$ & 1 & $Y$ & SE $1 / 4, \mathrm{NE} 1 / 4, \mathrm{NH} 1 / 4$ & Sect 5 T5N R43E Troy \\
\hline Wenaha Camp Road & NCR & $v$ & 3 & $Y$ & SE $1 / 4, \mathrm{NE} 1 / 4, \mathrm{NH} 1 / 4$ & Sect 5 TSN R43E Troy \\
\hline Umat il la & $\mathbf{u}$ & vc & 4 & $Y$ & SE $1 / 4, \operatorname{NE} 1 / 4, \mathrm{NE} 1 / 4$ & Sect 1 T6N R42E Eden \\
\hline Crooked Creek & cc & vc & 2 & $Y$ & $\mathrm{SH} 1 / 4, \mathrm{SH} 1 / 4, \mathrm{NE} 1 / 4$ & Sect 27 T6N R42E Eden \\
\hline South Wenaha & SW & v & 2 & $Y$ & SH1 $/ 4, \mathrm{NE} 1 / 4, \mathrm{NE} 1 / 4$ & Sect 5 T5N R43E Troy \\
\hline Wenaha Ravine & WR & $v$ & 1 & $\mathbf{Y}$ & $\mathrm{SE} 1 / 4, \mathrm{NH} 1 / 4, \mathrm{NE} 1 / 4$ & Sect 5 T5N R43E TrOY \\
\hline Elloit Bend & EF & B & $\geq 3$ & $Y$ & $\mathrm{NH} 1 / 4, \mathrm{NH} 1 / 4, \mathrm{SE} 1 / 4$ & Sect 9 T5N R43E Troy \\
\hline Grouse Creek & GC & vc & 0 & 0 & NE1 14, SH1 $/ 4$, SH1 $/ 4$ & Sect 24 T5N R43E Troy \\
\hline Hoodoo Trail & H & vC & 3 & $Y$ & SE 1/4, NE 1/4, SH 1/4 & Sect 29 T6N R42E Eden \\
\hline Maggie Canyon & $M C$ & B & $\geq 2$ & $Y$ & $\mathrm{NH} 1 / 4, \mathrm{SE} 1 / 4, \mathrm{NH} 1 / 4$ & Sect 3 T5N R43E Troy \\
\hline Lighte Flat & LF & B & $\geq 2$ & $Y$ & NHT $/ 4, \mathrm{SH} 1 / 4, \mathrm{NH} 1 / 4$ & Sect 3 T5N R43E Troy \\
\hline Squaw Canyon \#1 & sc1 & B & $\geq 4$ & $Y$ & NH1 $/ 4$, SE $1 / 4, N H 1 / 4$ & Sect 35 T6N R43E Troy \\
\hline Squaw Canyon \#2 & $\operatorname{sc2}$ & $\mathbf{B}$ & $\geq 2$ & $Y$ & NE 1/4, SH1/4, NE $1 / 4$ & Sect 35 T6N R43E Troy \\
\hline Floral Grade & $\mathbf{F}$ & v & $\geq 2$ & C & $\mathrm{SE} 1 / 4, \mathrm{SH} 1 / 4, \mathrm{NH} 1 / 4$ & Sect 1 T5N R43E Troy \\
\hline South Grande Ronde & SG & $\mathbf{B}$ & 3 & Y & NH1/4, SH1/4, NH1/4 & Sect 17 T5N R43E Troy \\
\hline Saddle Mountain & SM & B & $\geq 2$ & $Y$ & $\begin{array}{l}\text { SE1/4, SH1/4, NE1/4 } \\
\text { Saddle Butte }\end{array}$ & Sect 29 TTN R43E \\
\hline Wenaha River & $H$ & v & $\geq 1$ & $Y$ & SH1/4, SH1/4, NH1/4 & Sect 5 TSN R43E Troy \\
\hline Cougar Creek & $c$ & $\mathbf{v}$ & $\geq 1$ & $Y$ & $\begin{array}{r}\text { NE } 1 / 4, \text { NE } 1 / 4, \text { NH } 1 / 4 \\
\text { Mountain View }\end{array}$ & Sect 32 T7N R44E \\
\hline
\end{tabular}

- Map Symbols are used to indentify the stratigraphic sections on Plate 1 and used to indentify each section in Appendix $A$.

+ Type section indicates the method used to measure each stratigraphic section.

VC - vertical complete section through all flows present at the site.

$V$ - partial vertical section through selected flows.

B - lateral section to dtermine horizontal variations through one or more flows.

$\$$ The total number of brecciated flows present.

\& Troy Brecciated indicates if the Troy flow contained explosion structures ( $Y$ ) or lacks explosion structures $(0)$ or the Iroy flow was covered (C). 
brecciated flows in one section is six at the Eden Bench section (EB) near the town of Troy and west of the Grande Ronde fault system. The spatial distribution of the stratigraphic sites and the observed number of brecciated flows at each stratigraphic or reconnaissance site show brecciated flows occur on both sides of the Grande Ronde fault system (Figure 5).

At the Grouse Creek stratigraphic section (GC), brecciated flow areas are not present and do not occur within at least one km of this site (Figure 5). The Grouse Creek site (GC) is located northeast of the town of Troy, is near the junction of the northeast-trending Courtney Creek fault and the northwest-trending Squaw Canyon fault, and is west of the Horseshoe Bend fault (Figure 5; the Grouse Creek section is the only solid circle). These faults are part of the Grande Ronde fault system (Ross, 1978). Brecciated flows occur on either side of the axis of the Grouse Flat syncline and adjacent to the Saddle Butte anticline.

During the measurement of each stratigraphic section, intraflow characteristics were measured or noted (see appendix A for complete stratigraphic data). These intraflow characteristics include the total thickness of each flow determined by elevations of both upper and lower contacts, jointing patterns and the relative position of each pattern within the flow, morphological profile of each flow, occurrence of vesicular or scoriaceous zones, and subjacent clay zones. If an explosion structure was observed within a flow, two major vertical intervals within the flow and, if possible, the trend of the central spine (the bearing of the plane 


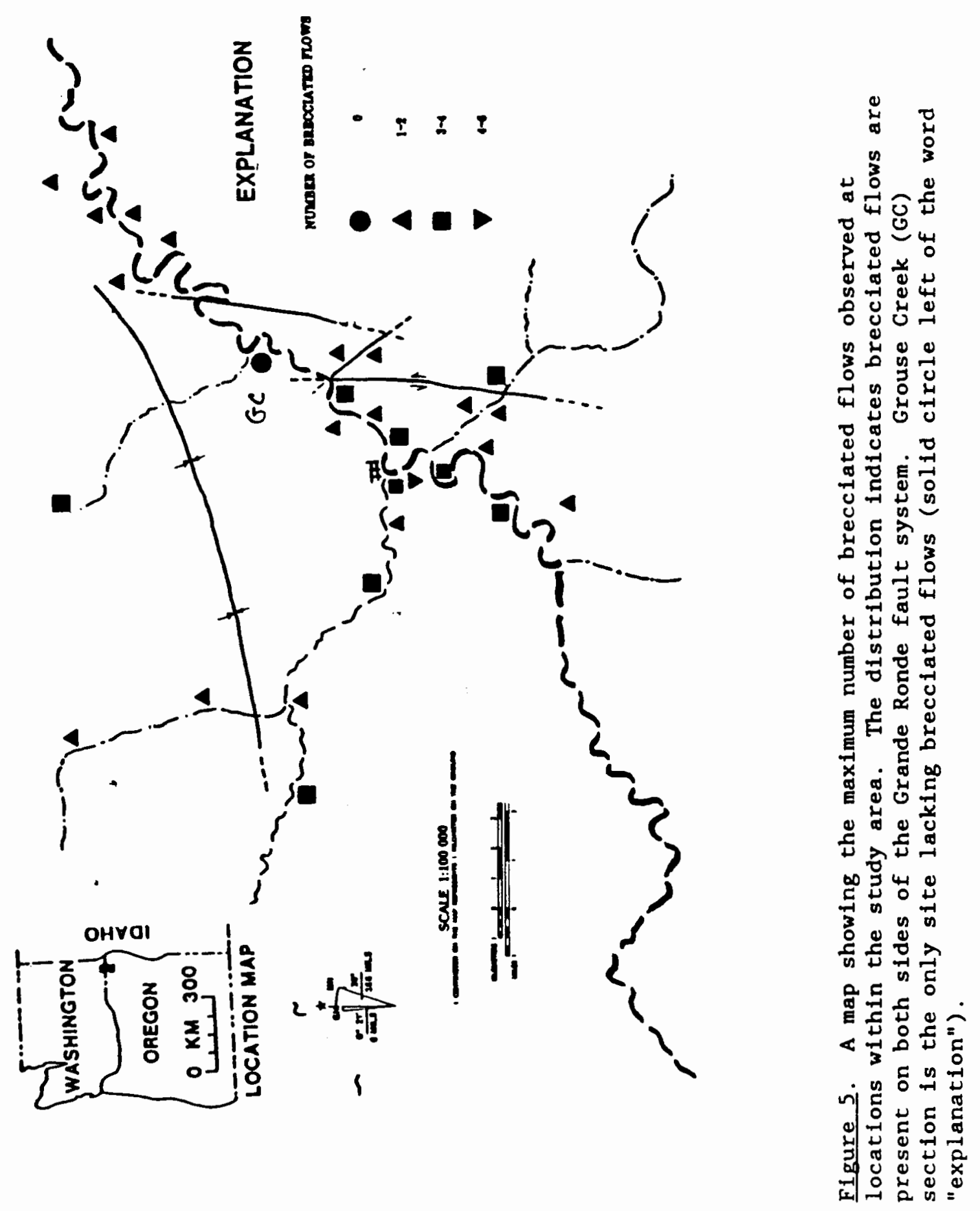


of the central spine) were measured. The two major vertical intervals are: 1) the breccia interval that consists of the vertical thickness between the first observation of breccia in an explosion structure to the upper contact with the overlying flow, and 2) the compact interval that consists of the remaining lower portion of the flow (Figure 6 and definitions section).

Data from the measurements from the two vertical intervals show that flows containing explosion structures range in thickness from thin flows ( $10 \mathrm{~m}$ ) to thicker flows ( $125 \mathrm{~m}$ ) (Table II). Although brecciated flows thinner than the Troy flow have similar explosion structures, these structures are less fully developed and are developed at a smaller scale than within the Troy flow. Figure 6 is a plot of the breccia interval against the total thickness of the brecciated flow. The graph indicates that thick brecciated flows greater than $30 \mathrm{~m}$ thick have a greater proportion of their thickness brecciated than thinner brecciated flows. For the thicker flows, 458 of the thickness is breccia whereas the average is less than 458 for thinner flows (Figure 6 ). The thinner brecciated flows are either younger or older than the Troy flow. The Troy flow data points plot towards the upper right hand of the graph, because they are generally thicker and have thicker breccia intervals than the thinner brecciated flows.

Trends of the central spine for the Troy flow are northeasterly at locations near the Grande Ronde fault system (Figure 7). To the west, away from the fault system, the preferred orientation is to the northwest. Northeast orientations within the 


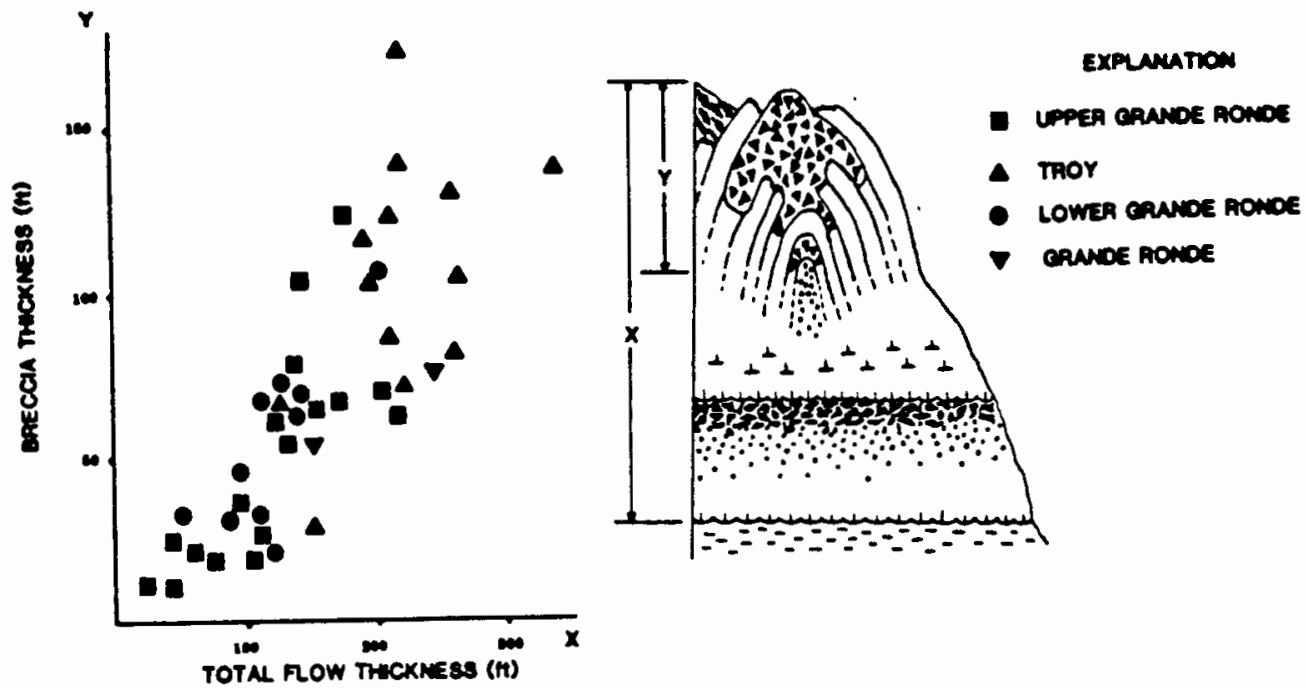

Figure 6. A graph showing the individual breccia intervals plotted against the total thickness of that flow. The collection of data points is grouped approximately along a line that has a slope of 0.5 . Troy flow data are grouped towards the upper right portion of the graph.

Troy flow nearly coincide with the northeast-trending faults of the Grande Ronde fault system; northwest orientations nearly coincide with the northwest-trending faults of the fault system and northwest orientation of the regional dikes. For flows above and below the Troy flow, orientations are both northwest and northeast.

The Troy flow was the primary flow studied, because within this flow explosion structures are large and widely distributed. Explosion structures within the Troy flow have been generalized to show only one central spine, but more than one spine may be present in some localities. Explosion structures locally occur in clusters with as little as 30 meters separating the structures. These 
TABLE II

THICKNESS OF BRECCIA TOP AND COMPACT INTERVALS FOR

BRECCIATED FLOWS AT VARIOUS LOCATIONS

\begin{tabular}{|c|c|c|c|c|c|}
\hline \&Location symbol & aflow type & $\begin{array}{l}\text { Thicknes } \\
\text { *Breccia interval }\end{array}$ & $\begin{array}{l}\text { s (feet) } \\
\text {-Compact interval }\end{array}$ & •TOTAL & $\begin{array}{l}\text { \&fraction } \\
\text { of breccia } \\
\text { interval }\end{array}$ \\
\hline EB & $\begin{array}{l}\text { UGR } \\
\text { UGR } \\
\text { UGR } \\
\text { TROY }\end{array}$ & $\begin{array}{r}60 \\
13 \\
125 \\
124\end{array}$ & $\begin{array}{r}69 \\
7 \\
48 \\
85\end{array}$ & $\begin{array}{r}129 \\
20 \\
173 \\
209\end{array}$ & $\begin{array}{l}.47 \\
.65 \\
.72 \\
.59\end{array}$ \\
\hline HC and WCR & $\begin{array}{l}\text { TROY } \\
\text { TROY } \\
\text { UGR } \\
\text { UGR }\end{array}$ & $\begin{array}{r}72 \\
157 \\
23 \\
28\end{array}$ & $\begin{array}{r}148 \\
181 \\
82 \\
80\end{array}$ & $\begin{array}{l}220 \\
338 \\
105 \\
108\end{array}$ & $\begin{array}{l}.49 \\
.46 \\
.28 \\
.26\end{array}$ \\
\hline$U$ & $\begin{array}{r}\text { LGR } \\
\text { TROY } \\
\text { UGR }\end{array}$ & $\begin{array}{r}70 \\
128 \\
26\end{array}$ & $\begin{array}{r}69 \\
130 \\
13\end{array}$ & $\begin{array}{r}139 \\
258 \\
39\end{array}$ & $\begin{array}{l}.50 \\
.50 \\
.67\end{array}$ \\
\hline CC & TROY & 68 & 55 & 123 & .55 \\
\hline WR & $\begin{array}{l}\text { TROY } \\
\text { TROY }\end{array}$ & $\begin{array}{l}138 \\
105\end{array}$ & $\begin{array}{l}200 \\
159\end{array}$ & $\begin{array}{l}338 \\
264\end{array}$ & $\begin{array}{l}.41 \\
.40\end{array}$ \\
\hline EF & $\begin{array}{l}\text { LGR } \\
\text { LGR } \\
\text { TROY } \\
\text { TROY }\end{array}$ & $\begin{array}{r}34 \\
85 \\
173 \\
139\end{array}$ & $\begin{array}{l}16 \\
16 \\
46 \\
80\end{array}$ & $\begin{array}{r}50 \\
101 \\
219 \\
219\end{array}$ & $\begin{array}{l}.68 \\
.84 \\
.79 \\
.63\end{array}$ \\
\hline$H$ & $\begin{array}{r}\text { UGR } \\
\text { UGR } \\
\text { TROY }\end{array}$ & $\begin{array}{l}22 \\
66 \\
39\end{array}$ & $\begin{array}{r}35 \\
136 \\
123\end{array}$ & $\begin{array}{r}57 \\
148 \\
152\end{array}$ & $\begin{array}{l}.39 \\
.45 \\
.26\end{array}$ \\
\hline LF & $\begin{array}{c}\text { LGR } \\
\text { LGR } \\
\text { LGR } \\
\text { TROY } \\
\text { TROY } \\
\text { TROY } \\
\text { TROY } \\
\text { UGR }\end{array}$ & $\begin{array}{r}107 \\
63 \\
46 \\
45 \\
93 \\
35 \\
90 \\
65\end{array}$ & $\begin{array}{r}89 \\
72 \\
49 \\
130 \\
164 \\
140 \\
154 \\
58\end{array}$ & $\begin{array}{r}196 \\
135 \\
95 \\
175 \\
257 \\
175 \\
244 \\
123\end{array}$ & $\begin{array}{l}.55 \\
.47 \\
.48 \\
.26 \\
.36 \\
.20 \\
.37 \\
.53\end{array}$ \\
\hline
\end{tabular}

\&Location symbol refers to the stratigraphic labels of Table $I$.

aflow type differentiates between the Troy flow (TROY), a Grande Ronde flow below the Troy flow (LGR), and a Grande Ronde above the Troy flow (UGR).

* Intervals used in Figure 6 .

\&he percentage of the flow that is brecciated. 
TABLE II CONTINNUED

THICKNESS OF BRECCIA TOP AND COMPACT INTERVALS FOR

BRECCIATED FLOWS AT VARIOUS LOCATIONS

\begin{tabular}{|c|c|c|c|c|c|}
\hline \&Location symbol & af low type & $\begin{array}{c}\text { Thickne } \\
\text { *Breccia interval }\end{array}$ & $\begin{array}{l}\text { s (feet) } \\
\text { *Compact interval }\end{array}$ & *TOTAL & $\begin{array}{l}\text { \&Fraction } \\
\text { of breccia } \\
\text { interval }\end{array}$ \\
\hline MC & $\begin{array}{r}\text { LGR } \\
\text { LGR } \\
\text { TROY } \\
\text { UGR }\end{array}$ & $\begin{array}{l}31 \\
42 \\
75 \\
65\end{array}$ & $\begin{array}{l}89 \\
42 \\
57 \\
61\end{array}$ & $\begin{array}{r}120 \\
84 \\
132 \\
126\end{array}$ & $\begin{array}{l}.26 \\
.50 \\
.57 \\
.52\end{array}$ \\
\hline sc1 & $\begin{array}{l}\text { UGR } \\
\text { UGR } \\
\text { UGR } \\
\text { UGR }\end{array}$ & $\begin{array}{r}83 \\
104 \\
134 \\
113\end{array}$ & $\begin{array}{l}52 \\
36 \\
44 \\
44\end{array}$ & $\begin{array}{l}135 \\
148 \\
178 \\
157\end{array}$ & $\begin{array}{l}.61 \\
.70 \\
.75 \\
.72\end{array}$ \\
\hline $\mathrm{SC2}$ & $\begin{array}{l}\text { UGR } \\
\text { UGR } \\
\text { UGR } \\
\text { UGR } \\
\text { UGR }\end{array}$ & $\begin{array}{l}70 \\
55 \\
21 \\
67 \\
11\end{array}$ & $\begin{array}{r}134 \\
75 \\
50 \\
102 \\
27\end{array}$ & $\begin{array}{r}214 \\
130 \\
71 \\
169 \\
38\end{array}$ & $\begin{array}{l}.34 \\
.42 \\
.30 \\
.40 \\
.29\end{array}$ \\
\hline $\mathbf{F}$ & $\begin{array}{l}\text { UGR } \\
\text { UGR }\end{array}$ & $\begin{array}{r}162 \\
86\end{array}$ & $\begin{array}{r}44 \\
282\end{array}$ & $\begin{array}{l}206 \\
368\end{array}$ & $\begin{array}{l}.79 \\
.23\end{array}$ \\
\hline SH & $\begin{array}{l}\text { TROY } \\
\text { TROY }\end{array}$ & $\begin{array}{l}138 \\
112\end{array}$ & $\begin{array}{l}200 \\
240\end{array}$ & $\begin{array}{l}338 \\
352\end{array}$ & $\begin{array}{l}.41 \\
.32\end{array}$ \\
\hline $\mathbf{w}$ & TROY & 105 & 159 & 264 & .40 \\
\hline GC & TROY & 0 & 172 & 172 & .00 \\
\hline SG & $\begin{array}{l}\text { LGR } \\
\text { LGR } \\
\text { TROY }\end{array}$ & $\begin{array}{r}72 \\
15 \\
104\end{array}$ & $\begin{array}{l}58 \\
49 \\
90\end{array}$ & $\begin{array}{r}130 \\
64 \\
194\end{array}$ & $\begin{array}{l}.55 \\
.23 \\
.54\end{array}$ \\
\hline SM & $\begin{array}{l}\text { GR } \\
\text { GR }\end{array}$ & $\begin{array}{l}77 \\
55\end{array}$ & $\begin{array}{r}170 \\
93\end{array}$ & $\begin{array}{l}247 \\
148\end{array}$ & $\begin{array}{l}.45 \\
.37\end{array}$ \\
\hline
\end{tabular}

\& Location symbol refers to the stratigraphic labels of Table 1.

aF low type differentiates between the Troy flow (TROY), a Grande Ronde flow below the Troy flow (LGR), and a Grande Ronde above the Troy flow (UGR).

*Intervals used in Figure 6.

\&The percentage of the flow that is brecciated. 


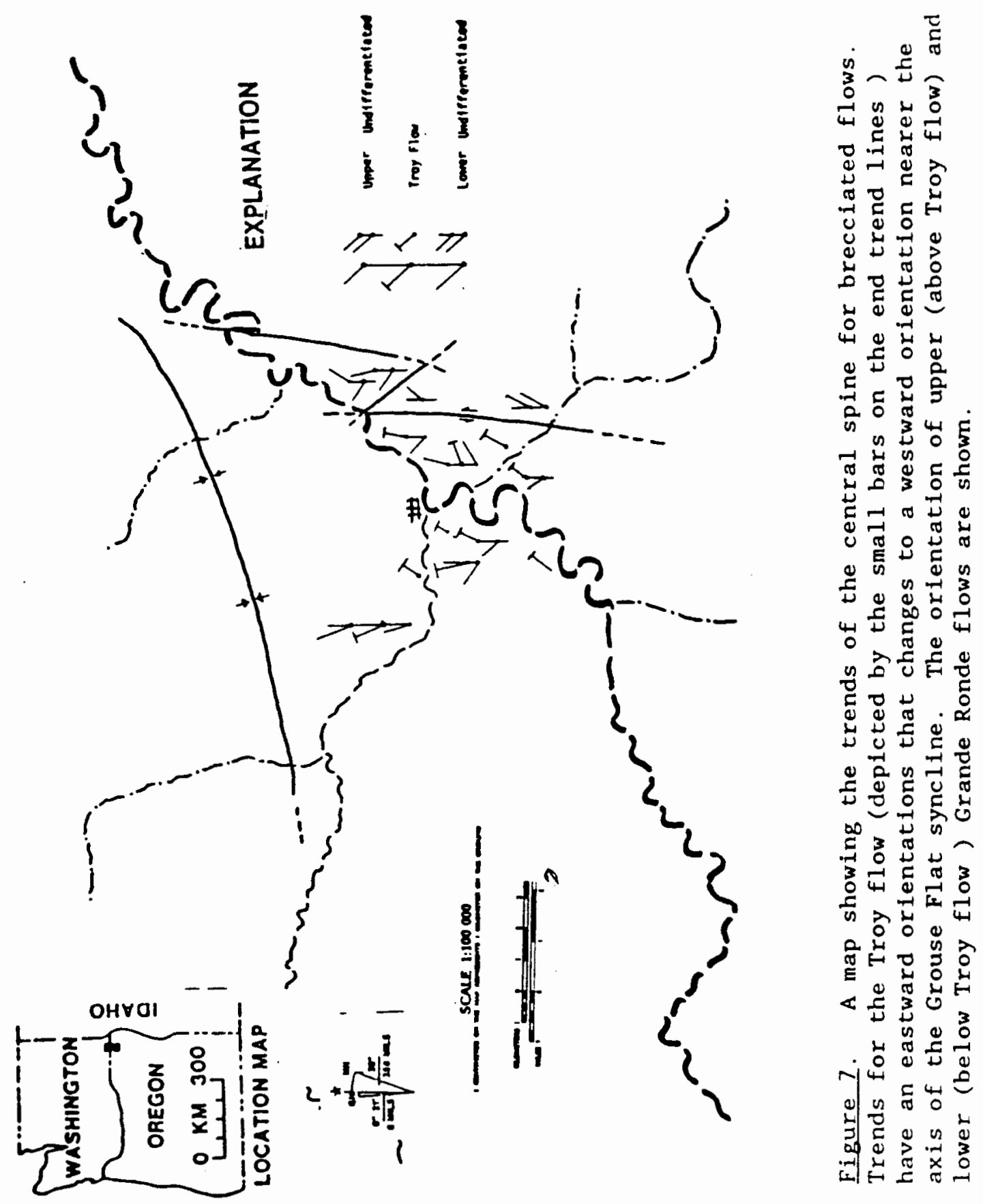




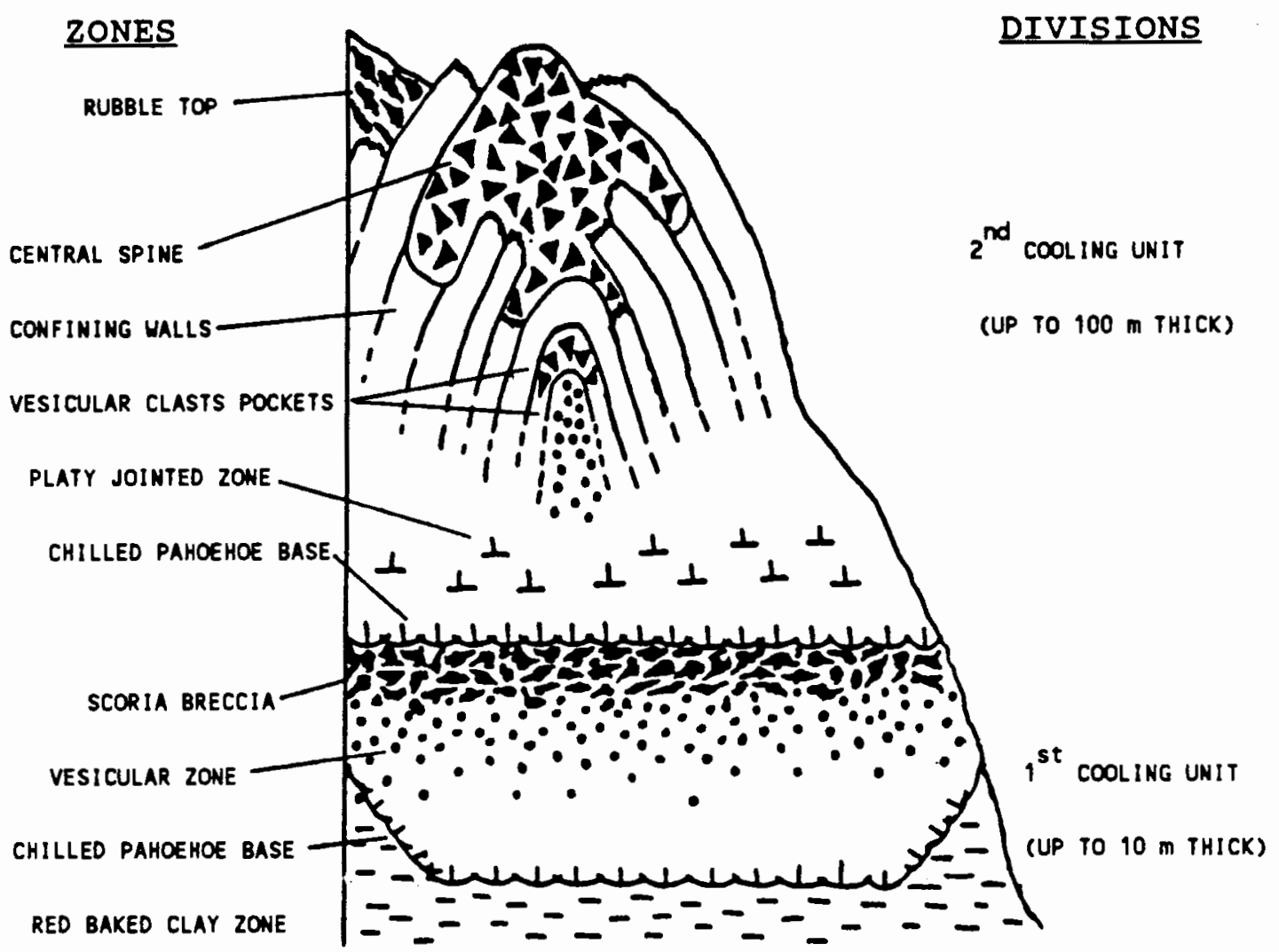

Figure 8. Generalized schmetic of a brecciated flow area showing two cooling units. The view is along the plane of the central spine. Intraflow zones are depicted for both units.

clusters may occur in close proximity to each other or may be widely spaced. The number of individual explosion structures in a cluster varies. Two well-exposed explosion structures were selected for vertical and horizontal traverse measurements.

The Troy flow at two stratigraphic locations, the Wenaha Ravine (WR) and the Elliot Farm (EF) sections, consists of two cooling units (Plate I). The term cooling unit is used as defined by Smith (1960), where a thinner precusor lobe of a flow represents the first cooling unit and is followed by a second lobe, the second cooling unit (Figure 8). For the Troy flow the first cooling unit 
is thin, up to $10 \mathrm{~m}$ in thickness whereas the second cooling unit is up to $100 \mathrm{~m}$ thick. A first cooling unit occupies a trough into the subjacent undulating pre-eruption topography. The amplitude of these undulation can be as great as $15 \mathrm{~m}$. A red, baked-clay zone up to a maximum of $2 \mathrm{~m}$ in thickness is present within the trough. This clay zone grades into the underlying, weathered flow-top breccia or scoriaceous top of the underlying flow. A Grande Ronde flow above the Troy flow shows similar cooling units within brecciated flow areas at the Squaw Canyon \#1 (SC1) and the Squaw Canyon \#2 (SC2) sections. At locations where flows were unbrecciated or nonbrecciated, only one cooling unit was found and a subjacent trough was absent.

The first and second cooling units in a brecciated flow area can be further subdivided into intraflow zones (Figure 8). Similar zones occur in the lower portions of the first and second cooling units. The zones are thinner in the second cooling unit than the first unit. These zones include a chilled pahoehoe base zone, inclined platy-jointed zone, sheared vesicular zone, banded vesicular zone, and, finally, a vesicular zone. The basal contact of both cooling units is marked by a chilled pahoehoe base (Figure 9). The chilled contacts have petrographic textures similar to textural zones found along the margin of a pillow of basalt (Bryan, 1972) (Table III). Samples from this chilled zone show quenched textures, including swallow-talled microphenocrysts of plagioclase and clinopyroxene in a matrix of non-vesicular brown glass, that grades inward to vesicular intersertal textures with black glass. 


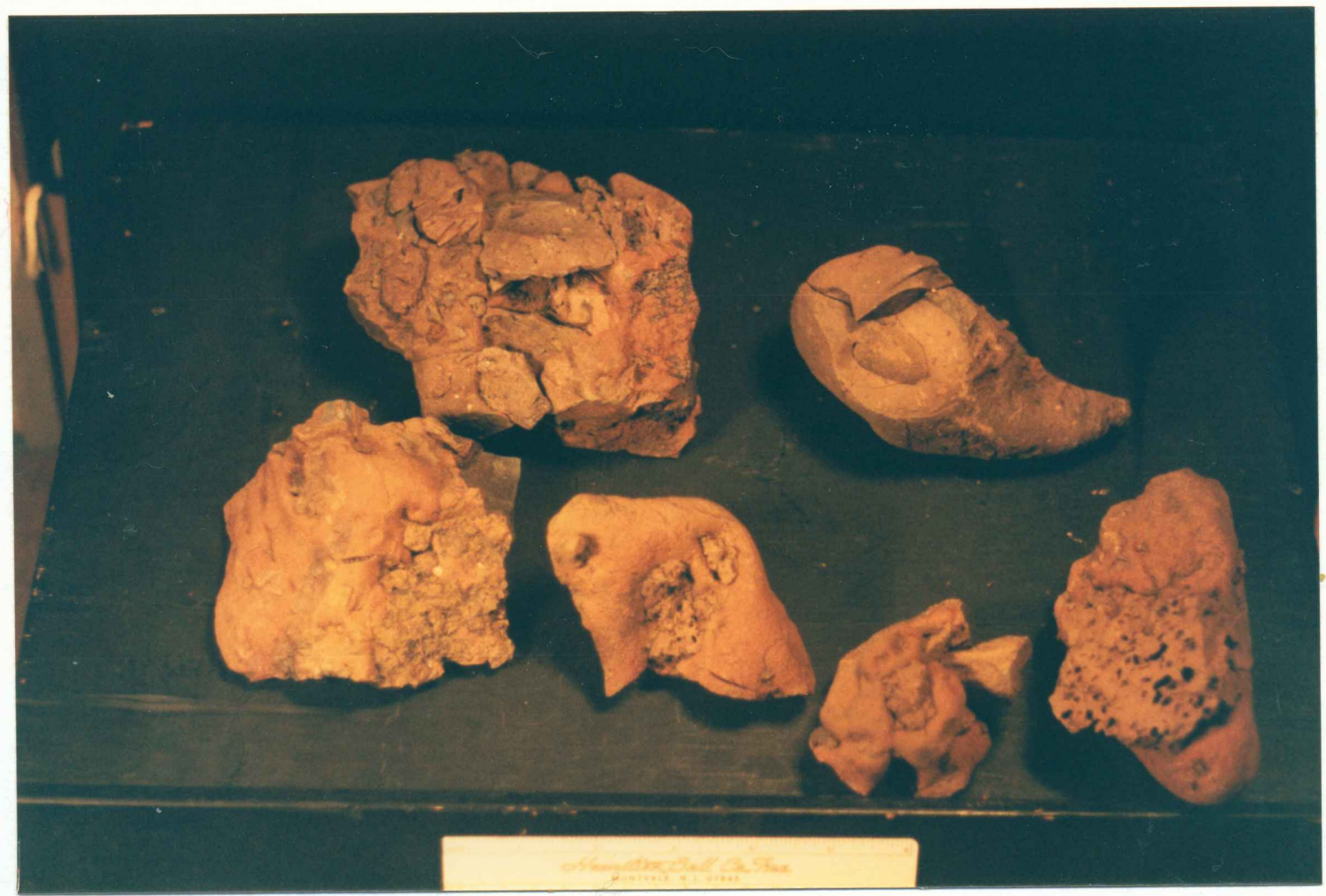

Figure 9. Samples from the chilled pahoehoe base of both the first and second cooling units of a brecciated flow area of the Troy flow. The three samples on the left side are from the base of the second unit, while the samples on the right are from the base of the first cooling unit. A pillow-like rind is visible on the upper right sample. Quench cracks are visible on the two lower left samples as dark lines on the surface of each sample. The ruler is approximately $15 \mathrm{~cm}$ long.

Rare cross-shaped microphenocrysts and microlites are found in thin sections and are composed of just one type of mineral in a cross shape. Cross-shape microphenocrysts and microlites can be found in most intraflow zones within both cooling units.

Another petrographic feature similar to a cross-shape grain is a skewed cross consisting of plagioclase and clinopyroxene. An 
TABLE III

SUMMARY OF FIELD AND PETROGRAPHIC CHARACTERISTICS FOR

THE ZONES OF A FIRST COOLING UNIT

Chilled Pahoehoe base Field: The rocks have an outer reddish-colored, coarse sandpaper textured

$\mathrm{rim}$, up to $15 \mathrm{~mm}$ thick. This outer surface is cut by quench fractures that are $v$-shaped, up to $15 \mathrm{~mm}$ deep, and are perpendicular to the surface of the sample. The undulating base consists of smooth lobate knobs of besalt that project into the underlying clay zone. These lobate knobs of basalt have wavelengths of $50 \mathrm{~mm}$ and ampitudes of $25 \mathrm{~mm}$. Commonly scoriaceous clasts from the flow project into the Pahoehoe base and are surrounded by projections from the base.

Thickness: $\leq 6 \mathrm{~cm}$

Jointing: none

Petrography: Textures: Vitrophyric textures grade inward from the contact surface. Quench cracks are observed to penetrate approximately $5 \mathrm{~mm}$.

Microphenocrysts: Rare microphenocrysts of plagioclase have quenched, swallow-tailed terminal ends. Microphenocrysts and microlites, where present, parallel the contact surface with the subjacent clay zone and grade inward to a subparallel alignment. Modal percent of microphenocrysts is $3.9 \%$; plagioclase (3.1\%) and clinopyroxene $(0.8 \%)$.

and away from the contact surface.

Vesicles: Vesicles occur towards the interior of the rock

Inclined platy zone Field: Wedge-shaped plates are up to $100 \mathrm{~mm}$ thick and up to $300 \mathrm{~mm}$ wide.

Plates consist of black-colored basalt that has sparse circular vesicles commonly filled with milkly white crystalline material or vesicules are coated with greenish-brown material. Grades upward into the overlying zone.

Thickness: $\leq 2.0 \mathrm{~m}$

Jointing: Joints of the individual plates are inclined upward 30 to 40 degrees and parallel to the subjacent contact base.

Petrography: Texture: Intersertal texture that generally lacks microphenocrysts of plagioclase or clinopyroxene.

$0.1 \%$.

Microphenocrysts: Modal percent of microphenocrysts is

randomly placed and filled.

Vesicles: Vesicles with a modal percent of $0.3 \%$ are

Sheared vesicular zone Field: Zone composed of vesicular basalt in which the vesicles are shaped similar to flattened diamond forms. The surfaces of the vesicles are marked by sharp jagged projections of basalt. Grades upward into the overlying zone.

Thickness: $\leq 1.0 \mathrm{~m}$

Jointing: None

Petrography: Textures: Intersertal texture and plagioclase and

clinopyroxene have increased in number from subjacent inclined platy zone.

Microphenocrysts: Microphenocrysts are parallel to the

plane of the flat crenulated vesicles. Modal percent of microphenocrysts is $11.2 \%$;

plagioclase (8.9\%) and clinopyroxene (2.2\%).

Vesicles: Vesicles are concentrated in zones when observed

in thin section. Modal percent of vesicles increased to $7.8 \%$.

Field characteristics were from vertical and horizontal traverses through an explosion structure described in appendix $C$ and field notes at the outcrops. Petrographic characteristics are from appendix $B$. 
TABLE III CONTINUED

SUMMARY OF FIELD AND PETROGRAPHIC CHARACTERISTICS FOR

THE ZONES OF A FIRST COOLING UNIT

Zone

Field characteristics followed by Petrographic characteristics

\begin{abstract}
Vesicular bands
Field: Zone composed of basalt containing planar bands of vesicles, that compose up to 60 percent of the rock and the bands are parallel to the joints of the inclined platey jointed zone. These vesicular bands have various thicknesses, but commonly up to $1 \mathrm{~cm}$ thick. Vesicles within the bands range from large (up to $10 \mathrm{~mm}$ in diameter) to small (2 $\mathrm{mm}$ in diameter), but are nearly circular in form. Large vugs, up to $50 \mathrm{~mm}$ long, are highly irregular to ellipsoidal in shape and the longest axis is parallel to the $t i l t$ of the subjacent inclined platy jointed zone. Grades upward into overlying zone.

Thickness: $1 \mathrm{~m}$

Jointing: None

Petrography: Textures: Very poorly to poorly developed intergranular-

textures in which vesicles are concentrated in bands.

clinopyroxene is observed in the thin section.

Microphenocrysts: Modal percent is $1.3 \%$ for plagioclase;

Vesicles: The mod
from the subjacent sheared vesicular zone.

Vesicular zone

Field: Zone consists of highly vesicular basalt and vesicles compose up to

$>60 \%$ of the rock. Vesicles range from circular (up to $2 \mathrm{~mm}$ in diameter)

to larger ragged vesicles (up to $7 \mathrm{~mm}$ in diameter). Small pockets of reddish-purple colored basalt are found as twisted/swirled forms towards the gradational contact with the superjacent zone.

Thickness: $2 \mathrm{~m}$

Jointing: None

Petrography: Not determined

Scoria breccia

Field: Scoriaceous breccia composed of a subjacent layer of matrix-

supported, reddish purple-colored clasts in black-colored basaltic matrix that grades into a superjacent layer of clasts-supported reddish purple-colored clasts. Clast shapes range from rounded to sharp and generally are larger, up to 50 $\mathrm{mm}$ in diameter, in the matrix-supported layer and decrease in diameter to $30 \mathrm{~mm}$ in the super jacent, clast-supported layer.

Thickness: $4 \mathrm{~m}$

Jointing: None

Petrography: Not determined
\end{abstract}

Field characteristics were from vertical and horizontal traverses through an explosion structure described in appendix $C$ and field notes at the outcrops. Petrographic characteristics are from appendix $B$. 
example of a skewed-cross grain consists of a single lath of plagioclase. Two grains of clinopyroxene project away from either side of the plagioclase grain at acute angles near the middle of the plagioclase lath. The two projecting grains lie in the same plane and often have similar optical extinction patterns. The reverse case also can be viewed in thin section, where the central lath is a clinopyroxene grain. These skewed crosses and glomeromicrophenocrysts of plagioclase and clinopyroxene have been observed in many of the intraflow zones in both cooling units (complete petrographical information in Appendix B).

Above the pahoehoe base, each successive zone grades upward into the overlying zone (Figure 10) (Table III). Intersertal textures are found in the inclined platy-jointed zone. Sparse vesicles occur within this zone, but the number of vesicles greatly increases in the overlying zones: sheared vesicular, banded vesicular, and vesicular zones. Vesicle shapes change from the inclined platy-jointed zone where sparse vesicles are small and spherical, to elongated vesicles in the three superjacent zones. The vesicles are not randomly distributed as in the inclined platy zone, but are grouped into layers or bands in sheared vesicular and vesicular bands zones. Vesicle shapes range from planar to crenulated in the sheared vesicular zone and range from spherical to irregular in the vesicular bands zone. Petrographic textures in the sheared vesicular and banded vesicular zones have that range from intersertal to very poorly to poorly developed intergranular. Microphenocrysts and microlites are arranged parallel to the 


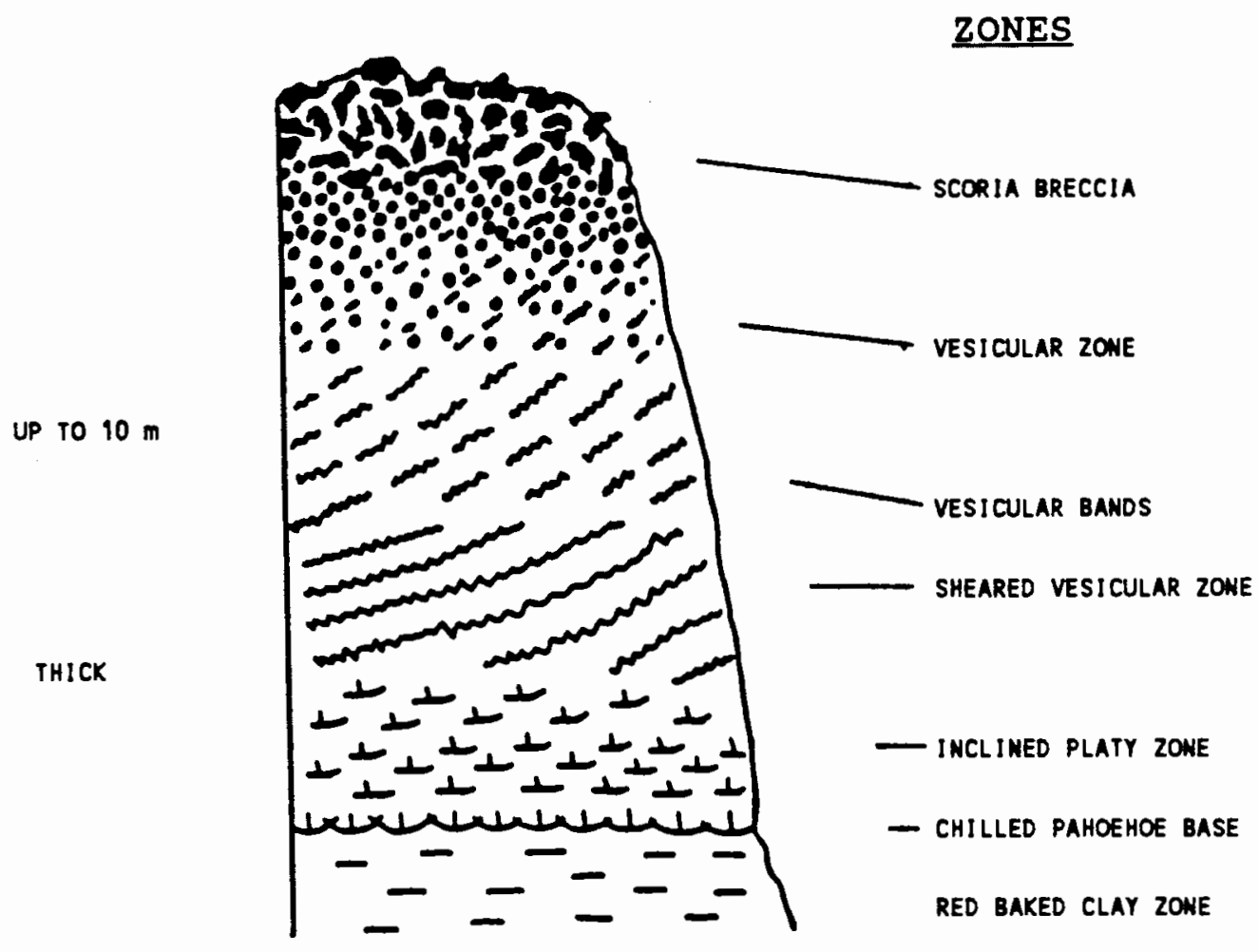

Figure 10. Generalized schematic of the first cooling unit parallel to the plane of the central spine.

Intraflow zones are shown in detail as each zones grades upward into the superjacent zones. The vertical thickness of each intraflow zone is generalized. The actual thicknesses are recorded in Table III.

alignment of the vesicles within the sheared vesicular zone.

In summary, a transition occurs at the base of the cooling units from the vitrophyric textures to poorly developed intergranular textures in the banded vesicular zone. The modal percentages of microphenocrysts of plagioclase and clinopyroxene decrease from the pahoehoe base, where microphenocrysts are the most abundant. The modal percentage of vesicles increases from sparse in the inclined platy-jointed zone to 238 in the vesicular bands zone. Distribution of vesicles is random only in the inclined platy zone, 
whereas in the other four zones, vesicles occur in distinct patterns.

A scoriaceous breccia caps the first cooling unit. The scorlaceous breccia grades from a lower matrix-supported breccia to an upper clast-supported breccia. Clast sizes decrease from the lower matrix-supported breccia to the upper clast-supported portion. This scorlaceous breccia zone is the thickest zone of the first cooling unit and is approximately twice the thickness of any of the subjacent zones.

The second cooling unit is also subdivided into zones; however markedly different zones occur in the upper portion of the unit (Figure 11 and Table IV). The lower zones of the second cooling

UP TO $100 \mathrm{~m}$ THICK

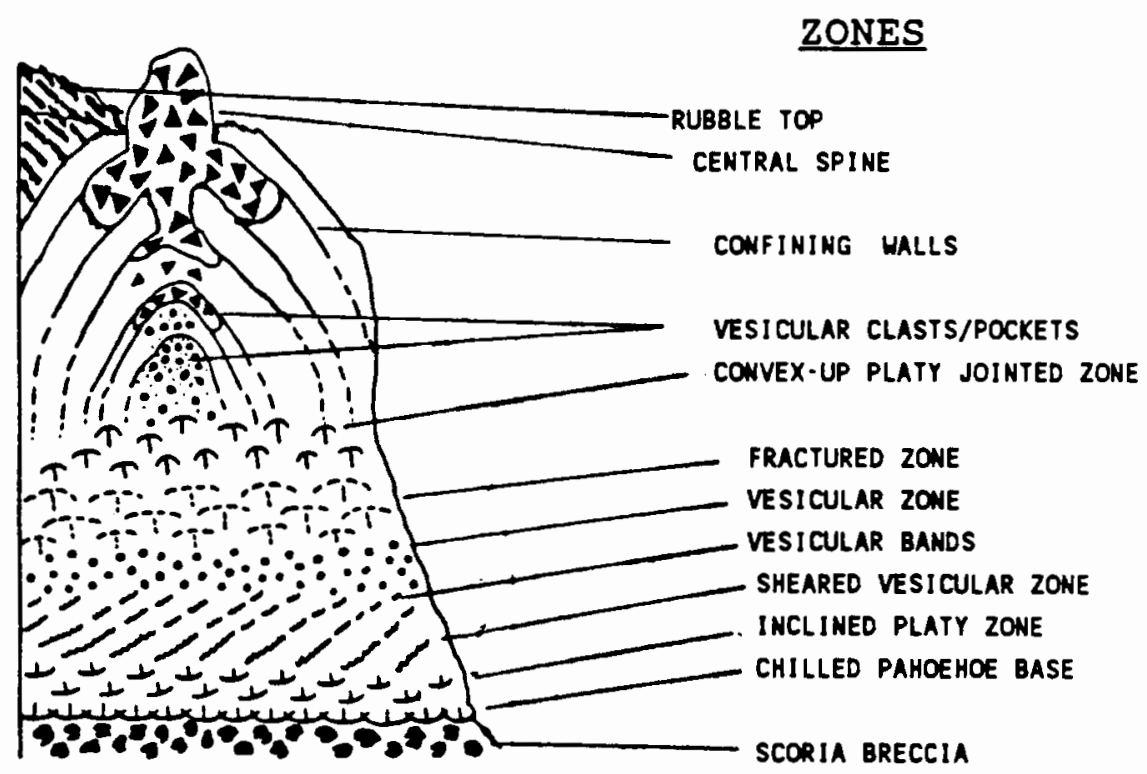

Figure 11. Generalized schematic of the second cooling unit viewed perpendicular to the plane of the central spine. Intraflow zones are shown in detail including similar basal zones to first cooling unit. The vertical thickness of each intraflow zone is generalized. The actual thicknesses are recorded in Table III. 
TABLE IV

SUMMARY OF FIELD AND PETROGRAPHIC CHARACTERISTICS FOR

THE INTRAFLON ZONES OF A SECOND COOLING UNIT

\begin{abstract}
Chilled Pahoehoe base field: Similar field characteristics to first cooling unit. Thickness: $6 \mathrm{~cm}$ Jointing: None

Petrography: Textures: similar to first cooling unit. Micropenocrysts: Modal percent is $0.5 \%$ Vesicles: Modal percentage is $1.6 \%$.

Inclined platy zone field: Similar field characteristics to first cooling unit. Thickness: $.2 \mathrm{~m}$ Jointing: None Petrography: Not determined

Sheared vesicular zone Field: Similar field characteristics to first cooling unit. Thickness: $.1 \mathrm{~m}$ Jointing: None Petrography: Hot determined

Vesicular bands Field: Similar field characteristics to first cooling unit. Thickness: $.1 \mathrm{~m}$ Jointing: None Petrography: Not determined

Vesicular zone Field: The vesicular zone consists of basalt containing vesicles which account for 40 to 60 percent of the rock. Vesicles are randomly distributed within this zone and are circular to slightly elongate with diameters from $2 \mathrm{~mm}$, generally circular, to $10 \mathrm{~mm}$, generally elongate.

Thickness: $\leq .3 \mathrm{~m}$

Jointing: None

Petrography: Not determined

Fracture zone Field: zone is composed of highly fractured undulating platy jointed basalt. Individual plates are up to $150 \mathrm{~mm}$ in thickness and cut by irregular vertical fractures. This zone grades upward into the superjacent zone. Thickness: $\leq 20 \mathrm{~m}$

Jointing: Joints are parallel to the unduating base of the second cooling unit.

Petrography: Not determined
\end{abstract}

Field characteristics were from vertical and horizontal traverses through an explosion structure described in appendix $C$ and field notes at the outcrops. Petrographic characteristics are from appendix $\mathbf{B}$. 
TABLE IV CONTINUED

SUMMARY OF FIELD AND PETROGRAPHIC CHARACTERISTICS FOR

THE INTRAFLON ZONES OF A SECOND COOLING UNIT zone. Individual plates have similar sizes as in the underlying zone, but are shaped with convex plane pointed upward. Away from an explosion structure, this zone grades and merges into a platy jointed zone in the unbrecciated flow areas.

Thickness: $7 \mathrm{~m}$

Jointing: Joints are convex-up.

Petrography: Textures: Black-colored bands or layers of different textured basalt that range from vitrophyric to very poorly developed intergranular textures. Bands or layers can twist, swirl, pinch, and swell.

Microphenocrysts: Modal percentages of microphenocrysts for plagioclase are $1.5 \%$ and $0.3 \%$ for clinopyroxene. Vesicles: None

Vesicular clasts/pockets and confining walls
Field: Dense glassy basalt forms arch-shaped limbs that enclose either pockets of vesicles or clasts containing vesicles. Vesicles are contained in either reddish purple-colored and or black colored basalt. Individual vesicular clasts or pockets can be up to $100 \mathrm{~mm} z$ one in diameter and have circular to elongated vesicles with diameters up to $5 \mathrm{~mm}$. Vesicles can be partially filled with yellowish. green material. The number of vesicular clasts or pockets increases upward towards the central spine. Initially, lower in this zone, few vesicular pockets cut across the confining walls, but are enclosed and concentrated in small bodies at the top the arch. Upward through this zone, vesicular clasts cut the confining walls in greater numbers at the area near the top of the arch, finally grading into enclosed bodies of breccia. The vesicular clasts or pockets zone grades upward into the central spine zone.

Thickness: Vesicular clasts/pockets zone can be up to $30 \mathrm{~m}$ thick, while the confining walls can continue upward to the overlying contact.

Jointing: Jointing patterns are vertical in the areas away from the center of the explosion structure, but each joint trace tilts to horizontal in the center of the explosion structure. At the center of the arch in the lower portion of this zone, the joints pinch and swell around a choatic arrangement of plates compose of welded fragments. Surface features resembling ripple-like marks are observed on the individual plates.

Petrography: Texture: In the black-colored confining walls, similar bands, layers, and spheres of different textured basalt as in the convex-up platy zone are repeated. Confining walls adjacent to the trapped body of vesicular clasts or breccia again have different textured basalt, bands or layers or spheres, but the individual textures can be colored either red or black. Red-colored textures are generally intergranular, wile black-colored textures are typically vitrophyric to intersertal. In the trapped bodies of vesicular clasts and breccia, similar differing textures are found, but distinct clasts occur interwoven in the different textures and the different textures can be either red or black in color. The intensity of the deformation of the individual textures is more pronounced.

Field characteristics were from vertical and horizontal traverses through an explosion structure described in appendix $C$ and field notes at the outcrops. Petrographic characteristics are from append $i x$ B. 
TABLE IV CONTINUED

SUMMARY OF FIELD AND PETROGRAPHIC CHARACTERISTICS FOR

THE INTRAFLON ZONES OF A SECOND COOLING UNIT

Zone

Field characteristics followed by Petrographic characteristics

\begin{abstract}
Microphenocrysts: Modal pecentage of microphenocrysts is highest in the confining walls typically above $1.5 \%$, wile in the enclosed bodies modal percentage is below $1.5 \%$.

Vesicles: Vesicle abundance is largest in the enclosed bodies of vesicular clasts/pockets or breccia (15.1\%). Vesicle shapes in the enclosed bodies form irregular tears, while in the confining walls adjacent to these trapped bodies, vesicles shapes are planar, and crenulated. Intraclast vesicles of the enclosed bodies are spherical to enlongate and sharply contrast with the vesicles tears surrounding the clasts.

Central spine

Field: Central spine is composed of an inner core of clast-supported breccia, wich grades outward into a matrix-supported breccia. clast sizes range from blocks up to $1.5 \mathrm{~m}$ across in clast-supported core to lapilli sizes in the outer matrix-supported breccia. Clast types range from predominantly brecciated types to vesicular or scoriaceous and rare Pahoehoe types. Jointing is predominantly horizontal or convex-up. A central spine can continue to the superjacent contact and project above the surrounding flow-top breccia at some localities (stratigraphic section Elloit farm (EF)). unit thickness.

Thickness: Vertical thickness varies from $1 / 2$ to $1 / 3$ of the second cooling Jointing: Convex-up to horizontal in the lower third of the central spine and massive in the upper portion of the central spine.

Petrography: Not determined

Rubble top

Field: A zone containing flow-top breccia clasts and clasts from the explosion structure. Flow-top breccia clasts are scoriaceous, reddishcolored basalt and generally less than block sized. Clasts from the explosion structure are similar to types found in a central spine or are broken and weatered fragments of the confining walls.

Thickness: This zone is typically thicker adjacent the explosion structure (15 m) grading laterally into the flow-top breccia.

Jointing: None

Petrography: Not determined
\end{abstract}

Field characteristics were from vertical and horizontal traverses through an explosion structure described in appendix $C$ and field notes at the outcrops. Petrographic characteristics are from appendix $B$.

unit grade laterally away from the explosion structure into a

vesicular base that underlies a non-vesicular, platy-jointed zone.

The textures at the lower contacts of unbrecciated and non-

brecciated flow areas are markedly different from the chilled 
pahoehoe base within brecciated flow areas. The surface textures are rough and vesicular rather than smooth and non-vesicular (Figure 12).

Intersertal textures are found in the basal contact zone of

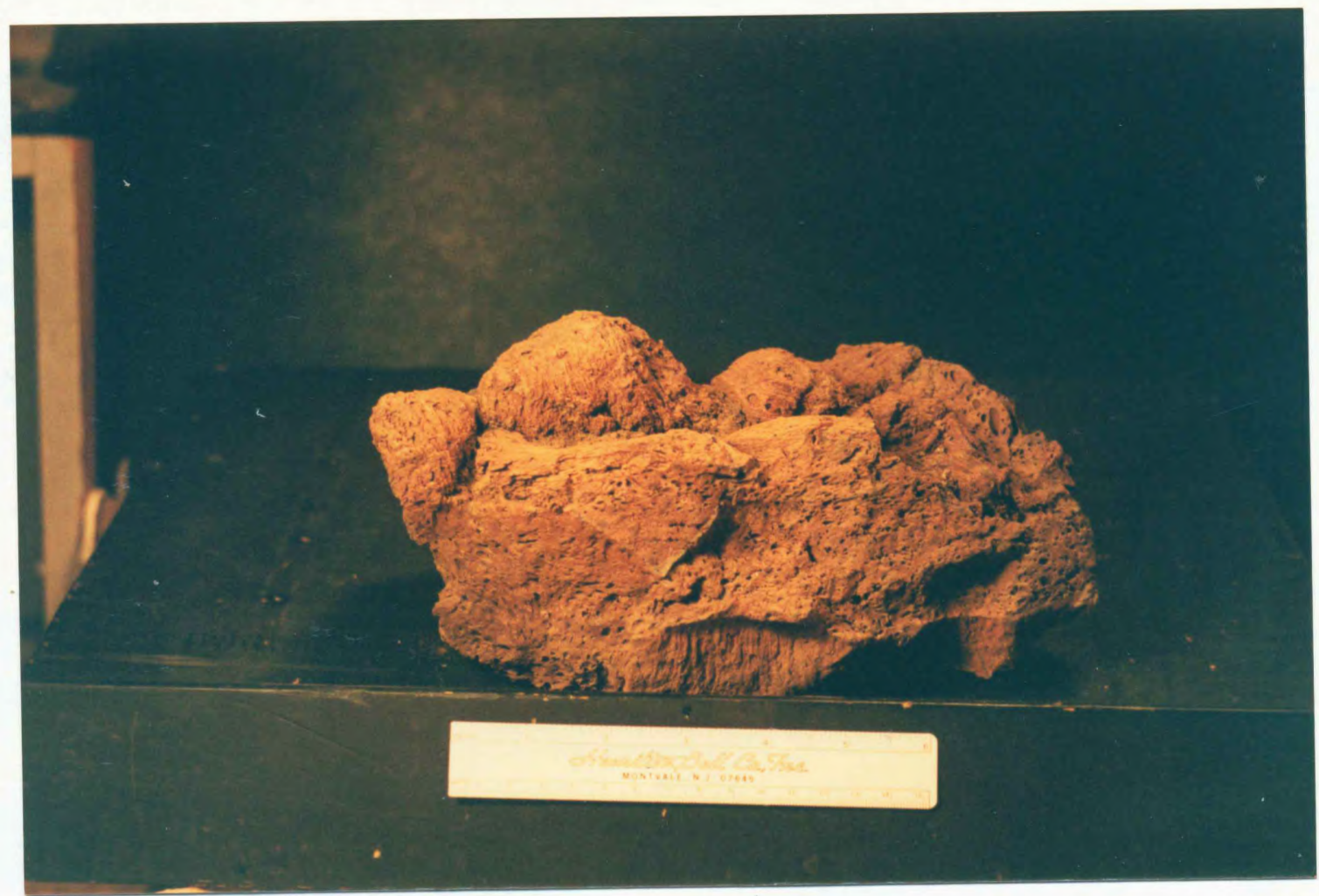

Figure 12. A vesicular sample of the base from a nonbrecciated flow area that shows a rough surface texture. This sample is quite different from the chilled Pahoehoe base in brecciated flow areas that are nonvesicular and have smooth surface textures. The ruler is approximately $15 \mathrm{~cm}$ long.

unbrecciated to non-brecciated flow areas and grade upward into the intergranular-textured interior of the flow. The intergranular texture is better developed within unbrecciated and non-brecciated flow areas than within the confining walls of an explosion structure where poorly intergranular-textured bands are present. The most 
we11-developed intergranular texture occurs in the non-brecciated flow areas. The abundance of microphenocrysts in unbrecciated flow areas is initially high within the basal contact zone (17.08), but decreases and remains fairly constant through the interior of the flow (averaging nearly 3.98). The abundance of microphenocrysts within non-brecciated flow areas is fairly constant at 3.58 while in brecciated flow areas the abundance of microphenocrysts, vesicles, and groundmass varies.

The zones that overlie the basal portion of the second cooling unit are varied and contain the most prominent breccia features in the flow. A highly fractured zone overlies the vesicular zone; this zone is platy jointed. Individual plates are cut by vertical fractures and the vertical fractures pinch and swell in irregular patterns. This fracture zone grades upward into another platyjointed zone, the convex-up platy zone, where individual plates have convex-upward shapes. The convex-up platy zone is laterally discontinuous, but grades laterally away from an explosion structure into a thick platy jointed zone.

The jointing pattern changes in the vesicular clasts/pockets and the confining walls zones from platy-jointing within the underlying convex-up platy zone to a foint pattern in the shape of an arch (Figure 11 and Table IV). The orientation of the joints is determined from the relative position within these two zones. Typically, joints are horizontal near the center of an explosion structure and vertical along the periphery. Surface features that resemble ripple marks are seen on the joint surfaces in each of 
these locations (Figure 13). The basaltic arms at the center of the arch and in the lower portion of these two zones are composed of

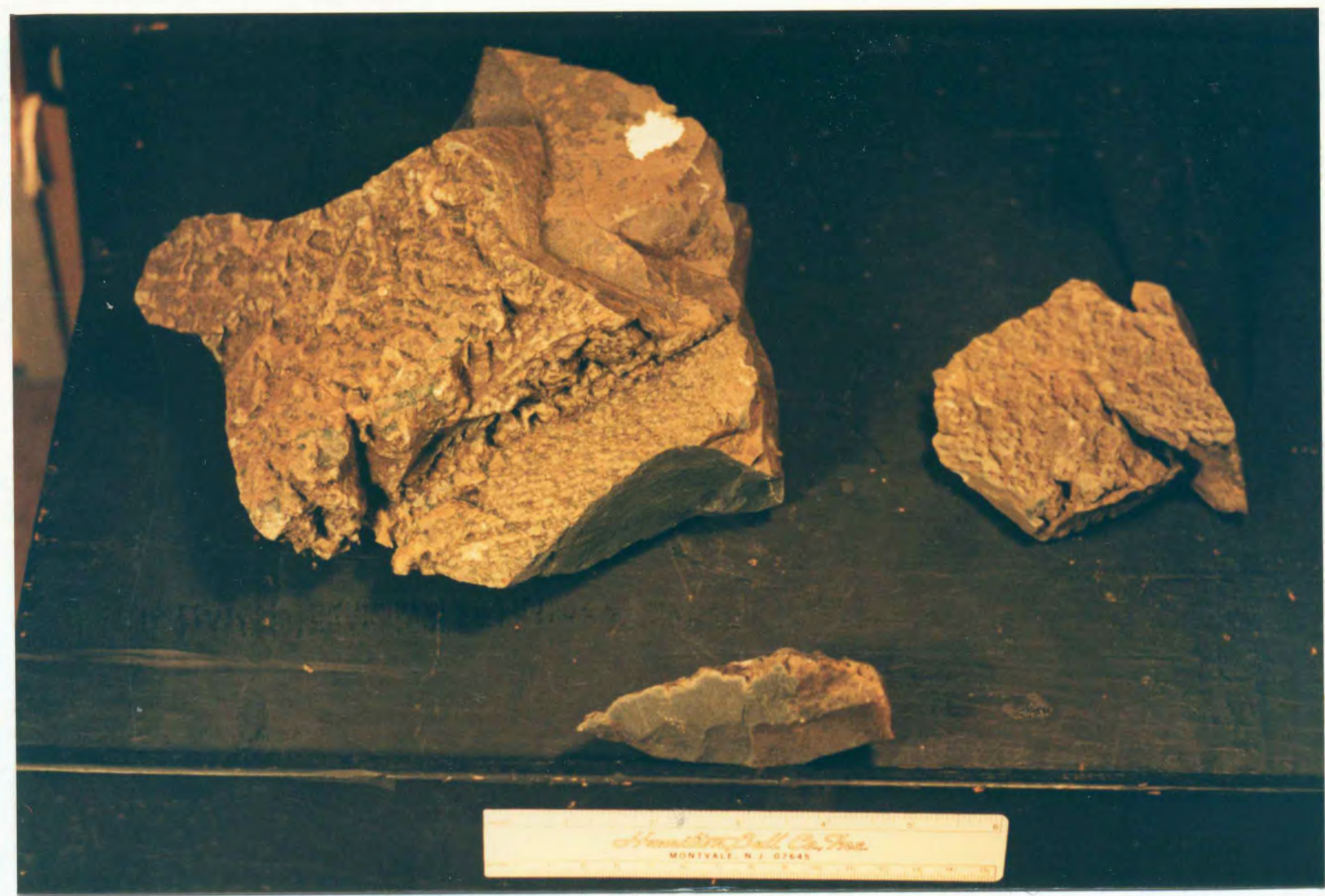

Figure 13. Samples from the confining walls zone showing the ripple-like marks along the joint traces. The two samples were collected from different locations with the Troy flow, but display similar patterns. The upper left sample has two parallel surfaces. A view parallel to the surface is seen in the center sample (a piece of the larger sample). The ruler is approximately $15 \mathrm{~cm}$ long.

plates consisting of welded fragments. These fragments are coated with clear-colorless, mammillary material and the individual surfaces of each plate have ripple-like textures (Table IV and Figure 14). These ripple-like marks are similar to ripple-like textures observed along the joint traces.

Vesicular pockets concentrate in bodies enclosed between 


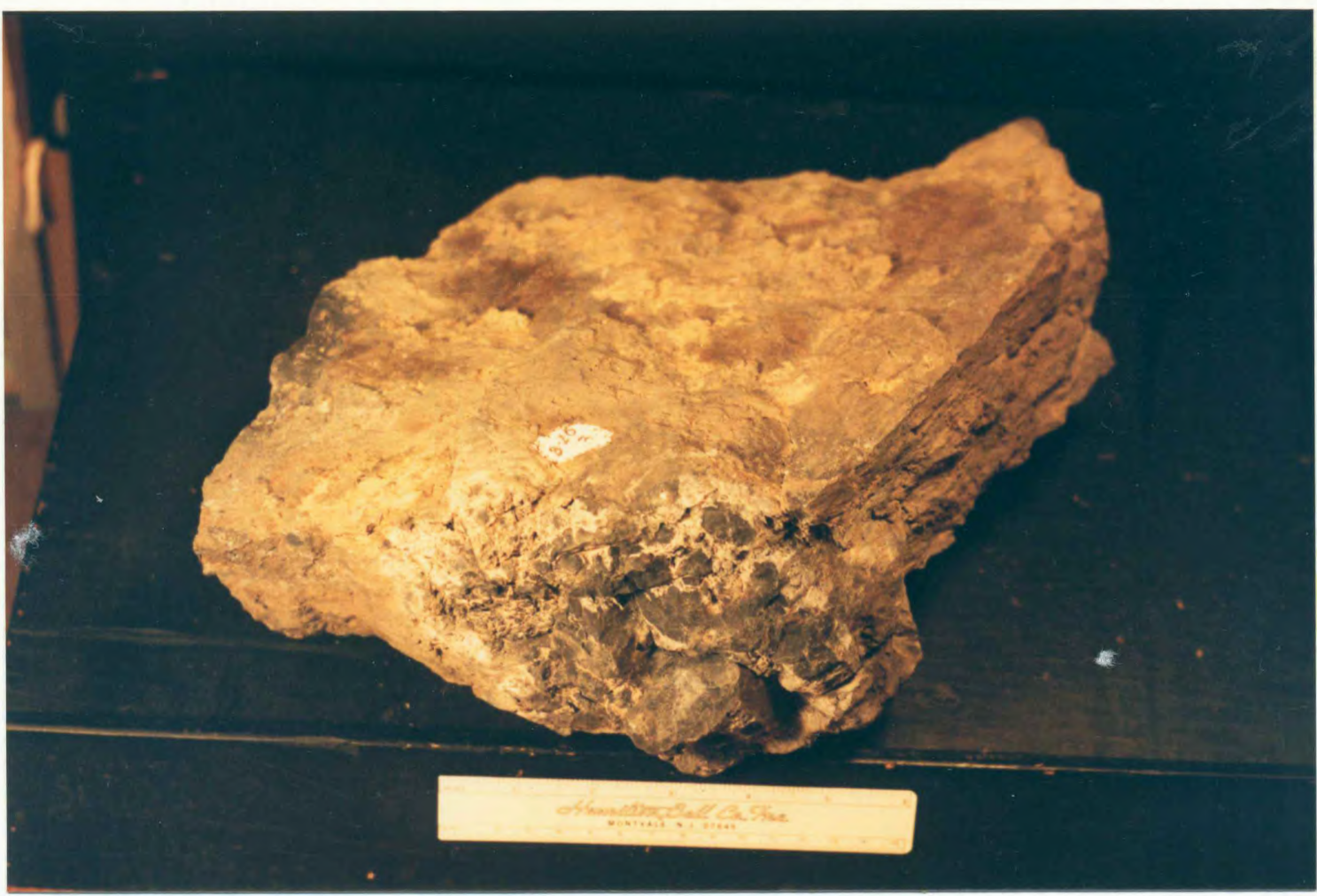

Figure 14. A single plate composed of welded fragments (the dark colored basalt). The plate was collected from the apex portion of the arch that is formed by the confining walls. Sample location is below the first appearances of vesicular clasts and pockets. Suface textures resembling ripple marks can be seen along the top surface as small ridges. The ruler is approximately $15 \mathrm{~cm}$ long.

black-colored basaltic arms near the center of an explosion structure (Figure 11). Vesicular pockets increase in number and size upward in an explosion structure and grade into vesicular clasts. Vesicular clasts are observed as a train of clasts cutting through the superjacent basaltic arms at the center of an arch and gathering in enclosed bodies of reddish-purple-colored breccia (Figure 15 and Figure 11). Reddish-colored basaltic arms enclose these bodies of breccia and grade into adjacent black-colored arms. 


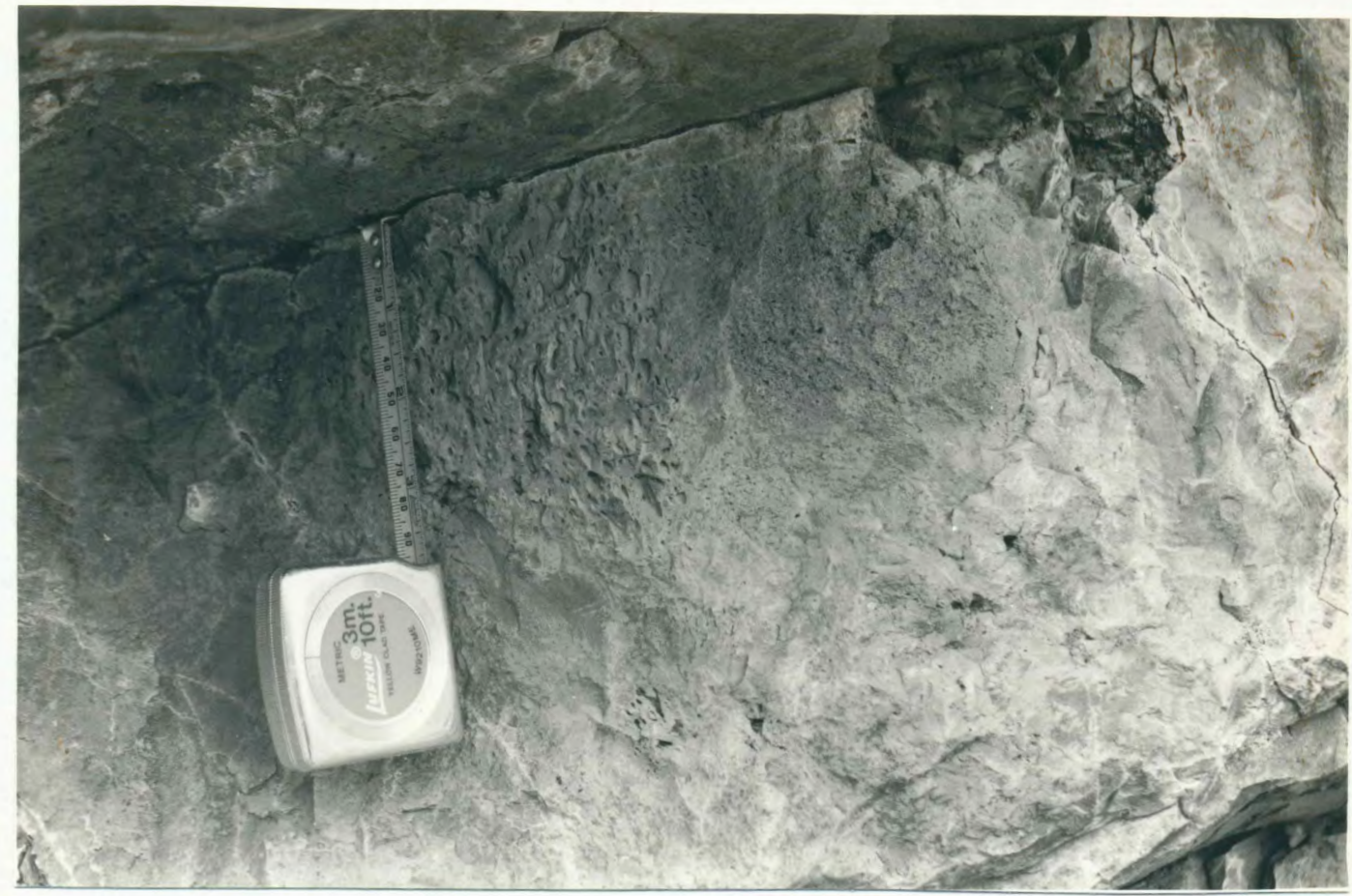

Figure 15. A scoriaceous clast observed within confining walls near the apex that includes several less distinct vesicular clasts. Collectively these vesicular clasts form a train between superjacent and subjacent enclosed bodies of vesicular clasts. Tape measure is approximately $11 \mathrm{~cm}$ long.

These differently colored basaltic arms are locally fragmented and become incorporated into the reddish-purple-colored breccia.

Petrographic evidence indicates a boundary occurs between a clast or a pocket and the surrounding basalt, but becomes evident in hand samples only in the upper portion of these zones as a dark reddish-colored rind. The black-colored basaltic arms enclosing vesicular pockets consist of vitrophyric to very poorly developed intergranular-textured basalt. The textures occur as thin intercalated bands or layers of poorly developed intergranulartextured basalt and vitrophyric-textured basalt. These bands or 
layers can have twisted, swirled, pinched and swelled patterns (Figure 16). The basaltic arms adjacent to the enclosed bodies of breccia consist of similar intercalated bands; however both types of bands are visibly reddish-purple.

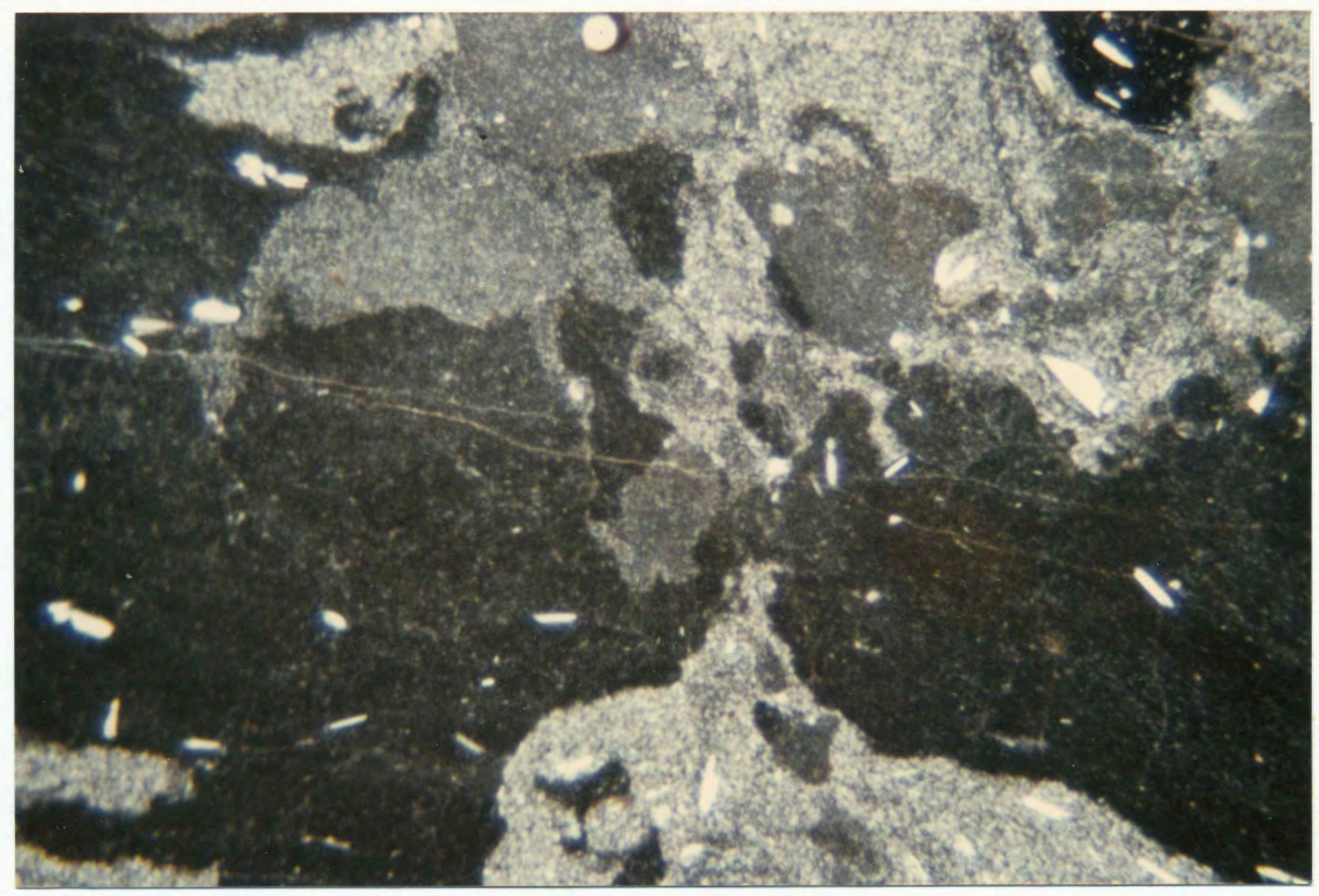

Figure 16. Petrographic textures in a sample from a basaltic arm that shows the twisting, pinching, swelling, and swirling of the individual bands or layers. Textures range from intergranular (lighter colored) to vitrophyric (dark colored). The view is approximately $1 \mathrm{~cm}$ across.

The transition from black-colored arms to reddish-colored arms is marked by planar bands of poorly developed intergranular-textured basalt, visible as reddish-colored bands, intercalated with blackcolored bands of vitrophyric-textured basalt (Figure 17). These bands can be less than $2 \mathrm{~mm}$ in thickness. Microphenocrysts of 
plagioclase are more abundant in reddish, intergranular-textured bands and are aligned parallel to the planar boundaries of the individual bands.

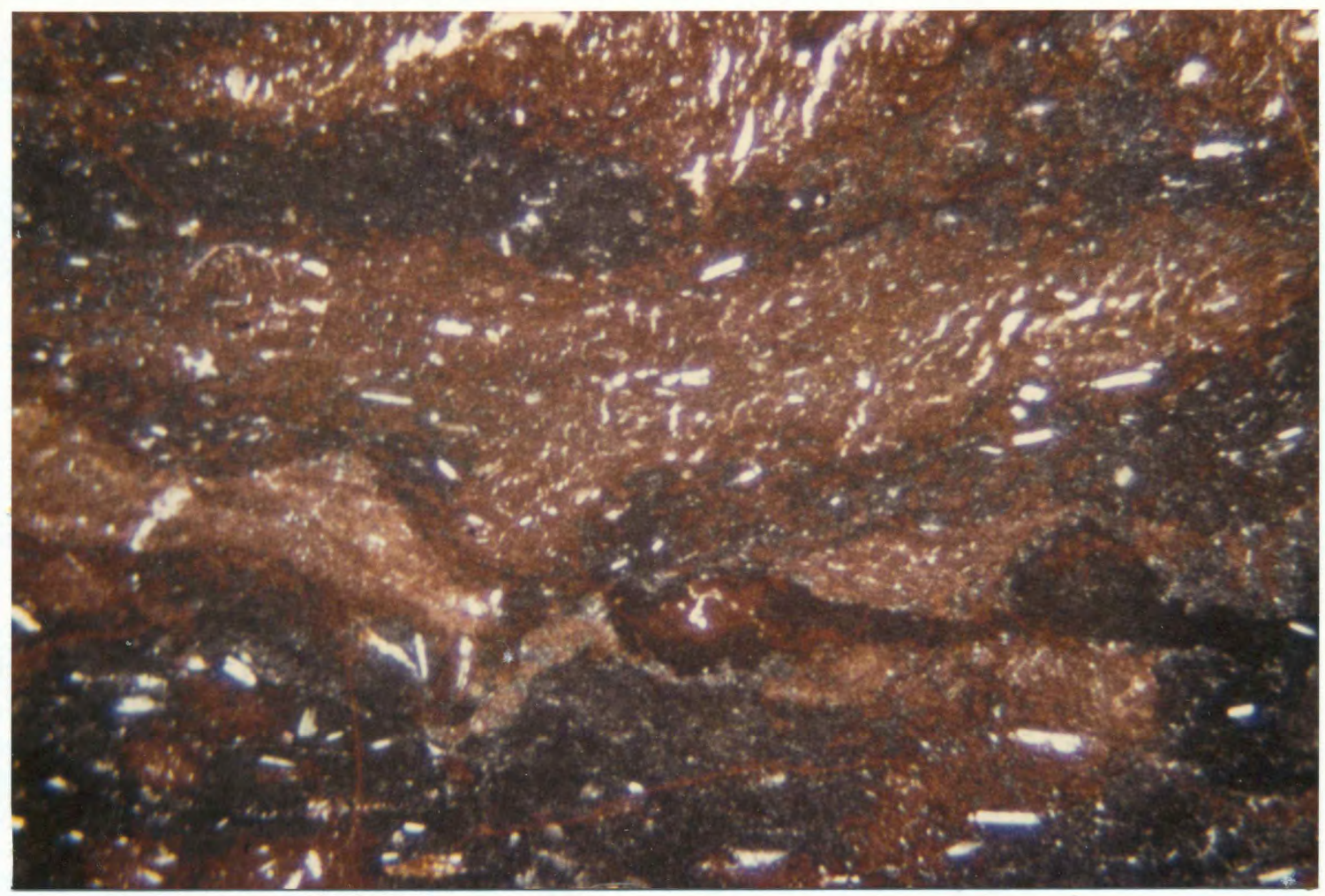

Figure 17. Petrographic textures showing the reddishcolored intergranular bands and the black-colored vitrophyric to intersertal bands. Vesicle tears (light colored) are evident in the intergranular bands as irregular wavy shapes especially in the center and upper reddish colored bands. The view is approximately $1 \mathrm{~cm}$ across.

The bodies of breccia in these settings are composed of matrix-supported clasts of reddish-purple-colored or black-colored, non-vesicular to vesicular to scoriaceous basalt in reddish-purplecolored basalt matrix (Figure 18). The size of the clasts varies from $30 \mathrm{~mm}$ in diameter to $2 \mathrm{~mm}$. The petrographic textures of the 
clasts within the breccia bodies range from textures similar to the black-colored basaltic arms to the reddish-colored arms. The abundance of vesicles within individual clasts varies. Vesicle shapes are spherical to elongated in the clasts; however vesicles within the matrix occur as irregular tears (similar to vesicle tears in Figure 18). The reddish-colored supporting matrix consists of bands or layers with vitrophyric to intergranular textures, but the chaotic patterns of these bands or layers is more pronounced than in the basaltic arms.

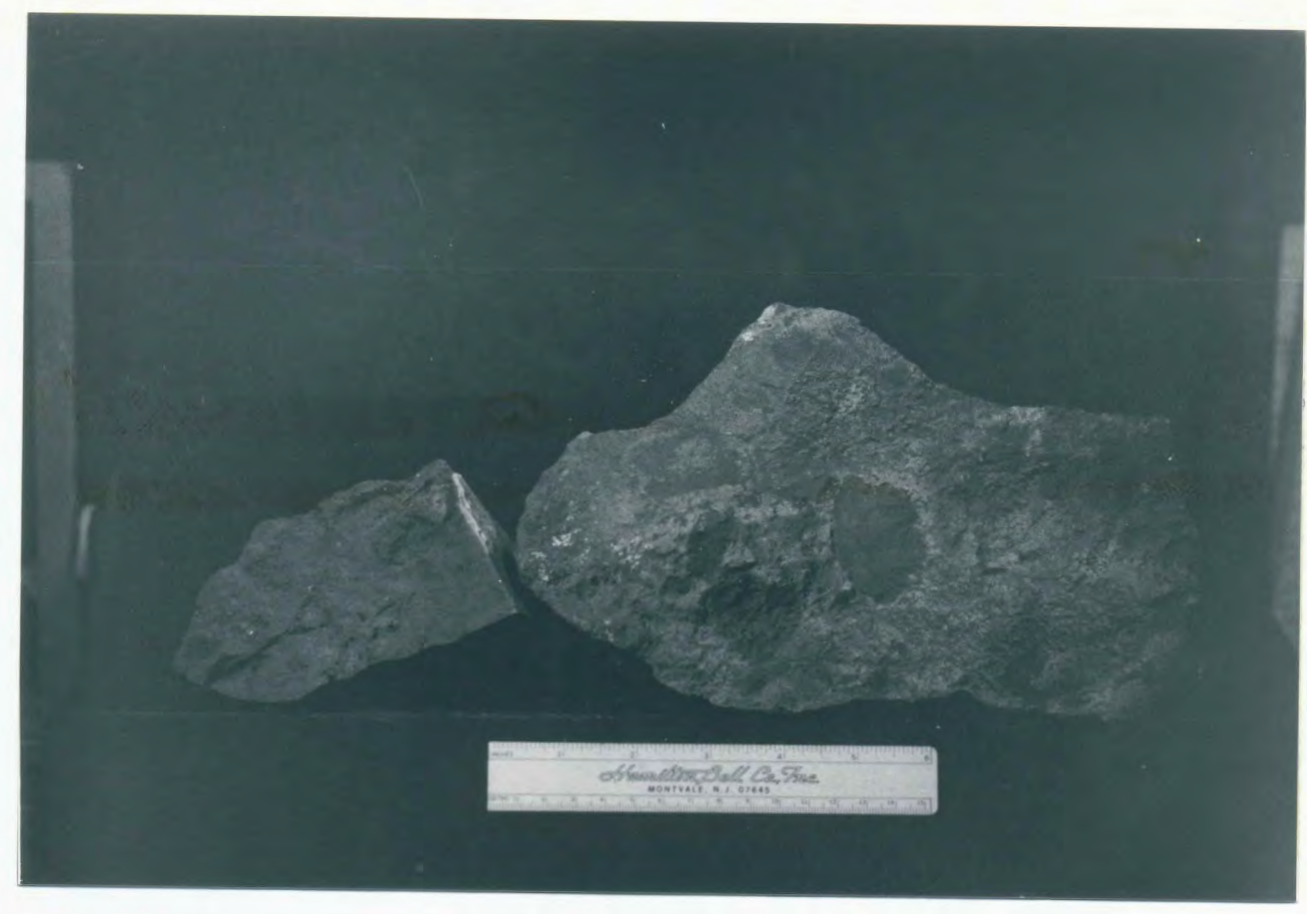

Figure 18. Two samples from a trapped body of breccia. The weathered surface of the right sample shows the outline of the individual clasts. The clasts in the center of this sample are non-vesicular, but a clast to the left of this one is vesicular. The matrix is better seen in the sample to the left and is reddish in color. The ruler is approximately $15 \mathrm{~cm}$ long. 
Farther upward, these enclosed bodies of breccla grade into a central spine zone of an explosion structure (Figure 11). The central spine in the lower portion of this zone may have confining walls or single basaltic arms that penetrate into the spine (Table IV). These projections terminate into fragments and are incorporated into the breccia along the peripheral margin of a central spine. The confining walls or arms typically contain vesicular clasts adjacent to the spine and then grade laterally into black dense basalt that lacks vesicular clasts or pockets.

Confining walls may extend upward to the contact with the overlyed basalt flow. The confined walls in this upper portion of an explosion structure become fragmented into small spheroids with diameters up to $10 \mathrm{~mm}$. The fragments are surrounded by a distinctly black-colored matrix and weathering accentuates the color differences in the field (Table IV and Figure 19).

Petrographic differences show a textural change from the spheroids to the darker matrix. Textures range from vitrophyric to intersertal in the black-colored matrix and very poorly developed intergranular in the spheroids. The color change observed in the field is related to these different textures. The vitrophyric to intersertal textures occur in alternating crenulated bands or layers that terminate in a swirled pattern. The intergranular textures occur as distinct spherolds within the other two textures. The abundance of microphenocrysts of plagloclase changes between the dark colored matrix and the spheroids, increasing abruptly in the intergranular textures. This rock is easily weathered into 


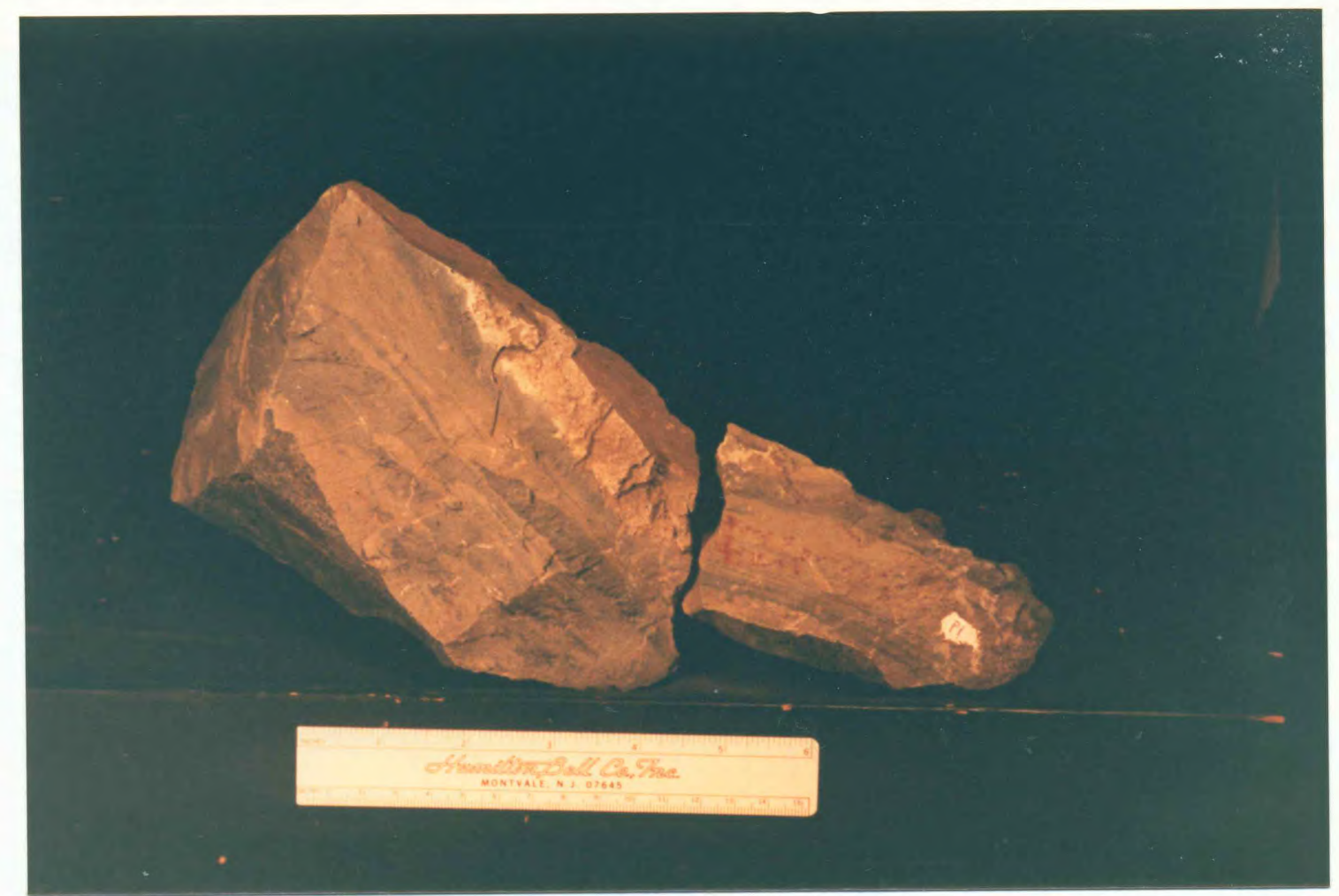

Figure 19. Two samples from the confining walls of an explosion structure showing differnt colored layer of basalt. These samples were collected near the contact with the overlying flow. The darker colored layers or streaks have greater proportions of glass, while the lighter basalt is more crystalline. The ruler is approximately $15 \mathrm{~cm}$ long.

fragments and these fragments occur within the sloped rubble top of an explosion structure.

A central spine is matrix-supported along the peripheral margins and within the lower portion of a spine. Individual clasts are elongate parallel to the sharp contact trace between the central spine and the adjacent confining walls. The resistant matrixsupported margin grades into a less resistant inner core of clastsupported breccia (Figure 20). Typically the inner core of breccia 
has been removed by erosion leaving a "v-shaped" notch in a central spine. Generally, field textures of the clasts are non-vesicular, aphyric basalt that may be red to black in color in the outer matrix-supported margin. In the inner clast-supported core, vesicular to scoriaceous-textured clasts increase in abundance. Clasts range from rare vesicular to scoriaceous blocks, up to $.63 \mathrm{~m}$ across, in the clast-supported breccia core to lapilli-sized clasts in the outer matrix-supported breccia.

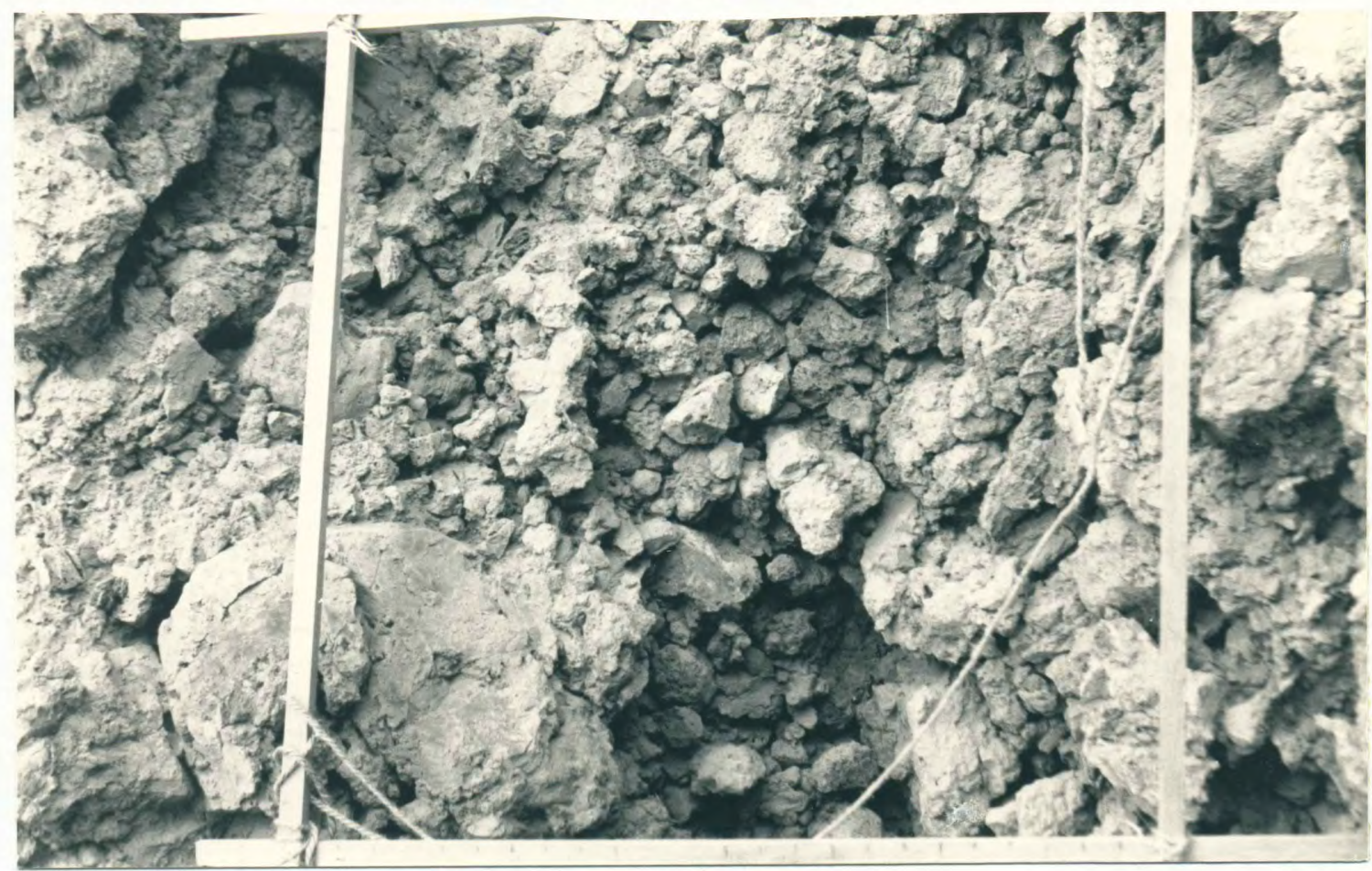

Figure 20. A transition to larger diameter clasts occurs from the outer matrix-supported breccia (left side) to the inner clast-supported breccia (right side). The largest clasts (bottom left) are composite type clasts. The wooden frame is $2 \times 2$ feet square.

Clast types were separated into two size categories, less than $64 \mathrm{~mm}$ and greater than $64 \mathrm{~mm}$. Lapilli-sized clasts were more difficult to count, because of the lichen cover on the outcrop 
surface. Three major types of clasts were used in the three counted traverses through both matrix and clast-supported breccias in a central spine (Figure 21). 1) A composite-type clast of welded fragments of non-vesicular to vesicular basalt in a reddish-purplecolored basalt matrix occurring as a single clast (BVA) (Table V).

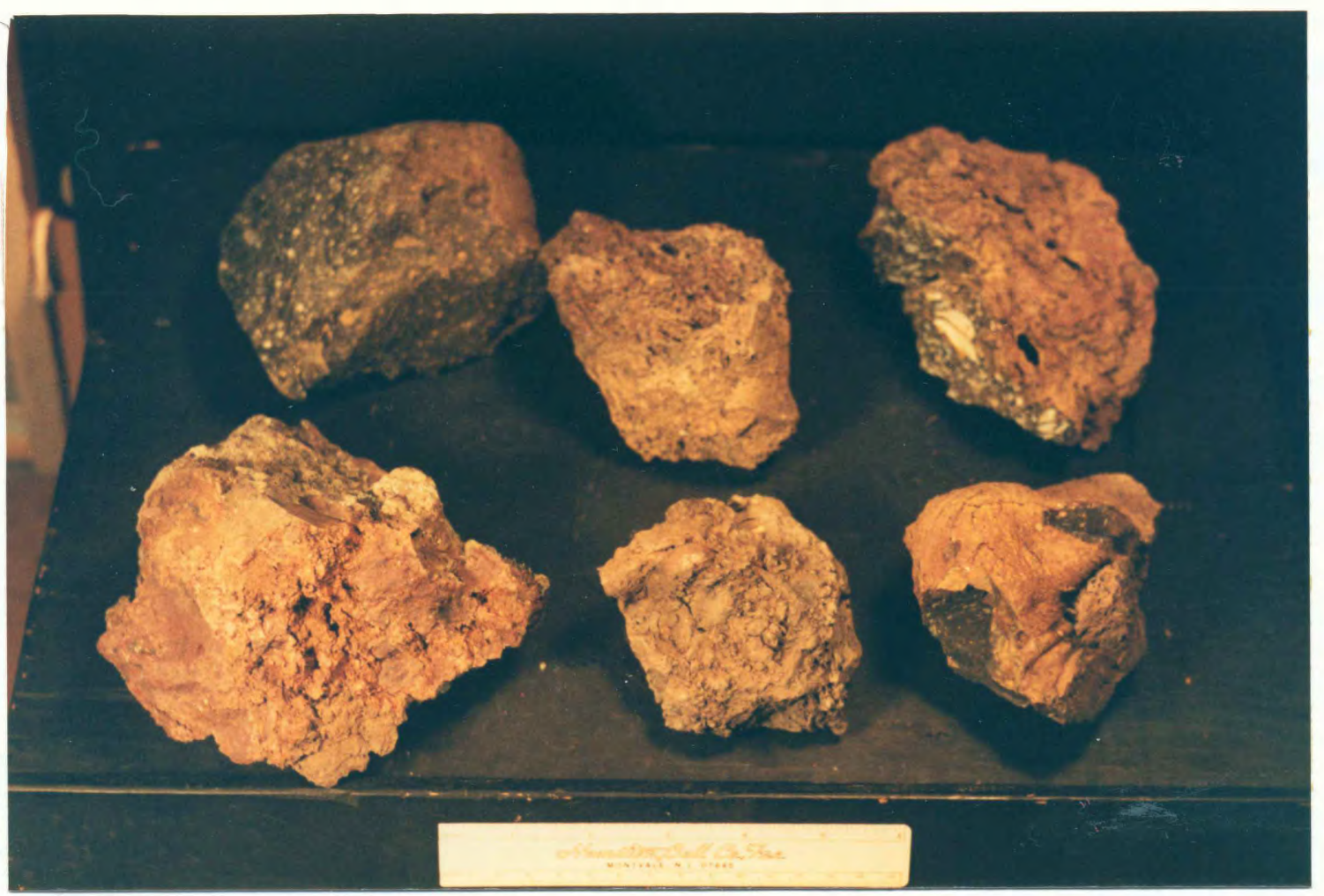

Figure 21. An assortment of three major clast types: pahoehoe clast $(6)$, scoriaceous clasts $(2,3)$, vesicular BVA (1), and nonvesicular BVA $(4,5)$. Clast (4) shows intraclast cracks and fractures and clasts (5) has a rind of finely brecciated fragments. The ruler is approximately $15 \mathrm{~cm}$ long.

The reddish matrix can be twisted, swirled, or stretched around the black to reddish-colored fragments. Intraclast cracks and fractures are often filled with fused finely brecciated fragments of basalt. 
A rind of finely brecciated fragments of black aphyric basalt and reddish-purple-colored matrix can be found on some of the blocksized clasts. 2) Scoriaceous-type clasts composed of black or reddish-colored scoriaceous basalt. 3) Pahoehoe-type clasts with ropey surfaces similar to Hawaiian pahoehoe flow-tops (Wentworth and others, 1953).

TABLE $V$

SUMMARY OF PERCENTAGES FOR CLAST TYPES ENCOUNTED DURING COUNTING TRANSVERSES

\begin{tabular}{|c|c|c|c|c|c|c|c|c|c|c|c|c|}
\hline$!$ & & & & pe of & & & & & & & $!$ & \\
\hline $\begin{array}{ll}\text { Type } & 1 \\
\text { of } & !\end{array}$ & & & $!$ & & - & $!$ & & 4 & $!$ & s & $\cdots$ & 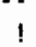 \\
\hline Support! & $<64 \mathrm{~mm}$ & $>64 \mathrm{~mm}$ & $!$ & $<64 \mathrm{~mm}$ & $>64 m$ & ! & $<64 \mathrm{~mm}$ & $>64 \mathrm{~mm}$ & $!$ & $<64 \mathrm{~mm}$ & $>64 \pi m$ & $!$ \\
\hline $\begin{array}{l}\text { Matrix } \\
\text { * Matrix } \\
\text { clast }\end{array}$ & $\begin{array}{l}86 \\
89 \\
62\end{array}$ & $\begin{array}{r}4 \\
11 \\
9\end{array}$ & & 19 & 4 & & 0 & 1 & & $\cdots$ & $\cdots$ & \\
\hline
\end{tabular}

\section{CLAST DESCRIPTIONS :}

BVA - Clast is a composite of clasts or fragments of black vesicular or non-vesicular, vitrophyric to intergranular-textured basalt with a reddish purple colored basaltic matrix. The matrix can be twisted, swirled, or stretched into layers that can be cracked or fractured. The cracks can contain very small fragments of rock, $\leq 1 \mathrm{~mm}$ in size. Some block-sized clasts are coated with a fused layer, up to $1 \mathrm{~mm}$ thick, of finely brecciated black-colored basalt and reddish-purple-colored matrix. Shapes of clasts range from sharp angular to planar to agglutinated froms. Rare empty interclast voids.

S - Clast composed of black or reddish colored scoriaceous basalt. Scoriaceous clasts show two types of either randomly placed vesicles through the clast or vesicles are concentrated in inflated vesicular margins. Shapes of clasts range from subrounded forms for the random vesicle type to plate-shaped forms for the inflated type of clast.

PAH - Clast composed of vesicular basalt with vesicles that are elongated and twisted parallel to the surface shape of the clast. Vesicles are up to $50 \mathrm{~mm}$ long, 2 to $3 \mathrm{~mm}$ thick, and up to 20 $\mathrm{mm}$ wide with vesicles often filled along the peripheral surface by dark green material. Clasts are colored blue gray internally and grade outward from yellow green to an orangebrown rim. Clasts have ropy surface texture. Clast shapes have generally plate-like forms. SP - Measurement of void space difficult to measure with 100 foot line method.

*Clasts were differentiated by size and not type.

The percentage of clasts from highest to lowest within a central spine are the composite-type (BVA), scoriaceous clasts, and pahoehoe clasts. Commonly, the size of the clasts is in the lapilli range $(\leq 64 \mathrm{~mm})$. The size of intraclast voids were measured, 
however, since voids in the breccia are three-dimensional features and irregular in shape, the void space was difficult to measure. A change in the distribution of clast-types occurs from the outer matrix-supported breccia to the inner clast-supported core. Composite-type clasts are predominant in both breccias, but the abundances of scoriaceous and pahoehoe-type clasts increase in the inner clast-supported core (Table V).

A central spine widens upward, the walls become less defined, and the breccia merges into a rubbly flow-top (Figure 11). Within the rubbly flow-top, clasts of composite (BVA), vesicular and nonvesicular clasts, scoriaceous clasts, and basaltic bombs are present. Clasts of the composite type (BVA) greatly increase in number within the upper portion of a central spine. Away from an explosion structure, a thick flow-top breccia is present and grades downward into the main body of the flow through scoriaceous and vesicular zones. The base of the flow-top breccia undulates and is at its lowest level within the flow adjacent to an explosion structure.

\section{GEOCHEMISTRY}

Samples were collected in conjunction with stratigrahic measurements or were collected from different textural zones during horizontal and vertical traverses (Appendix A for stratigraphic samples and Appendix D for traverse samples). Various samples were analyzed by three methods: INAA, Mossbauer spectroscopy, and XRF (Table VI and Appendix $E$ for preparation). All analyzed samples 
were analyzed by INAA; XRF was used on selected sets of brecciated, unbrecclated, and non-brecciated flow areas from the total sample set. Mossbauer spectroscopy was applied to a sample set at the interface of a trapped body of reddish-colored breccia and the adjacent confining walls.

Thirty-two samples were collected in five sample sets. Each sample set represents a complete or partial traverse within the three types of flow areas, brecciated, unbrecciated, or nonbrecciated. Twenty-two samples were collected through portions of either brecciated, unbrecciated, or non-brecciated flow areas, in the Troy flow. A special six sample set from these twenty-two samples was collected across an interface between a central spine and the adjacent confining walls of the Troy flow. A set of six samples, Squaw Canyon (SCl), was collected from a brecciated flow area of a Grande Ronde flow above the Troy flow. The position of each sample was recorded by the sample elevation within the flow and the textural features at that point. Since the Troy flow in the study area varies in thickness, each sample was given a relative position within a generalized model of the Troy flow; thus, comparisons were made between these corresponding sets of samples (Table VII). Each sample from the Squaw Canyon sample set was assigned a relative position based on similar textural characteristics with the brecciated flow area. 
TABLE VI

SUMMARY OF SAMPLE LOCATION AND SAMPLE LABORATORY ANALYTICAL METHOOS

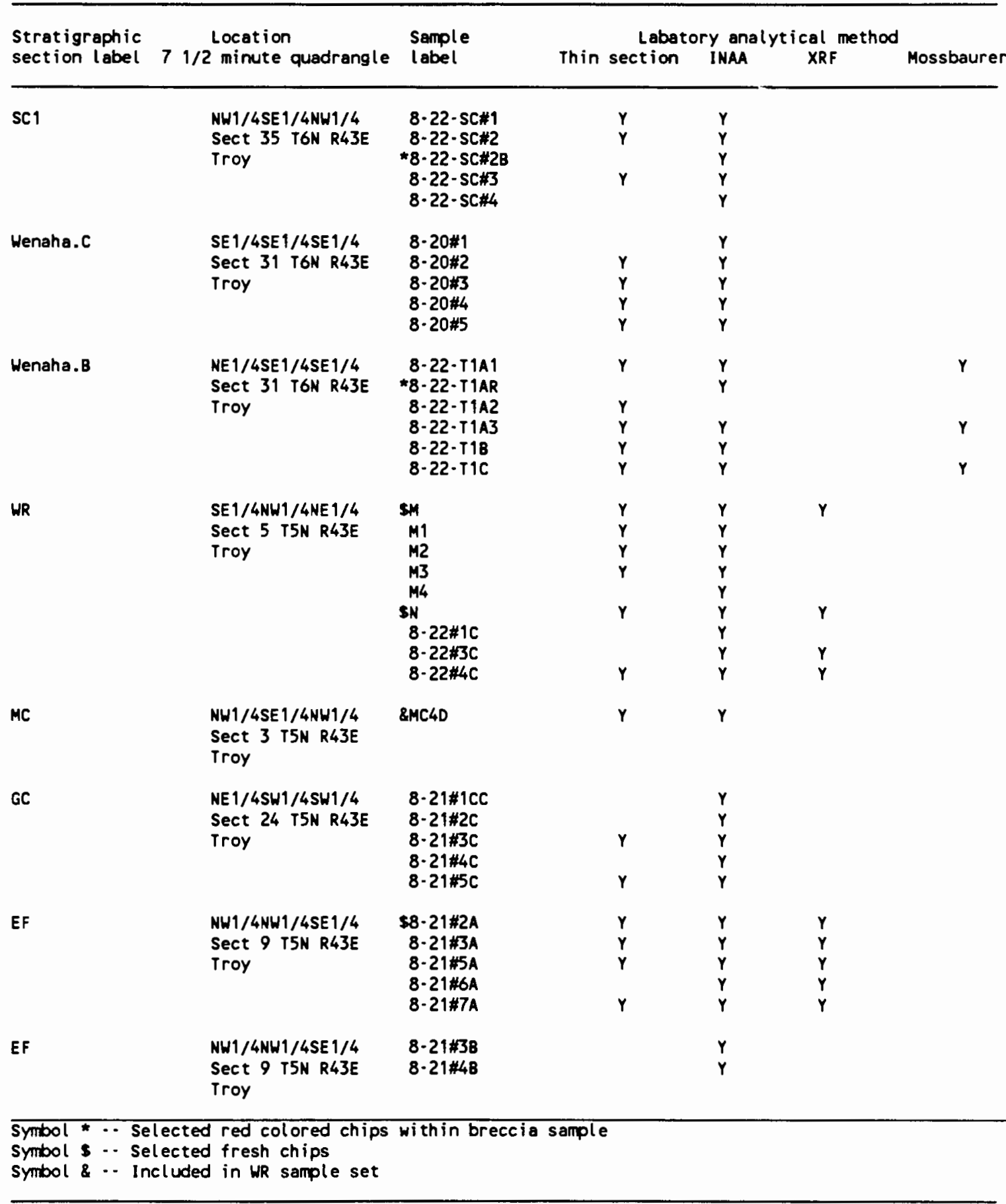


TABLE VII

EQUIVALENT SAMPLES COMPARING RELATIVE POSITIONS WITHIN A FLOW

\begin{tabular}{llllllll}
\hline Location label & Location label & Location label & Location label & Location label Intra- \\
Sample Flow & Sample Flow & Sample Flow & Sample Flow & Sample Flow flow \\
labels type & labels type labels type & labels type & labels type Zones \\
\hline
\end{tabular}

Wenaha Ravine(WR) Elloit Farm(EF) Grouse Creek(GC)

Wenaha.c Squaw Canyon(SC\#1)

MC4D

B

8-20\#1 B

8-22-SCH4 B

$\mathrm{CW}$

$8-20 \# 2$

B

$8 \cdot 20 \# 5$

8-20\#4

$8 \cdot 22 \cdot \mathrm{SCH}$

8-22-SC\#2B

$8-20 \# 3$

B

8-22-SCH2

$8 \cdot 22 \cdot S C \# 1$

$\begin{array}{ll}8 \cdot 22 \# 3 C & B \\ \text { N } & B \\ \text { M4 } & B \\ \text { M3 } & B \\ \text { M2 } & B \\ \text { M1 } & B \\ \text { M } & B \\ 8-22 \# 1 C & B\end{array}$

8-21\#7A

$8-21 \div 5 \mathrm{C}$

$8 \cdot 21 \# 4 C$

N

$8-21 \# 6 A$

$8 \cdot 21 \# 3 C$

H

$8 \cdot 2145 A$

$8-21 \# 2 C$

N

$8-21 \not 3 A$

$8-21 \mathrm{HCC}$

$8-21 \# 2 A$

$8 \cdot 21 \# 1 C C$

N

CW

$\mathrm{CW}$

EB

$\mathrm{CW}$

$\mathrm{CW}$

$\mathrm{CW}$

Positions were established by the sample's relative position to either the corresponding cooling (first or second) and the field textural zone within that particular cooling unit. Sample elevations are shown in the stratigraphic measured section figures.

Symbols used in the above table

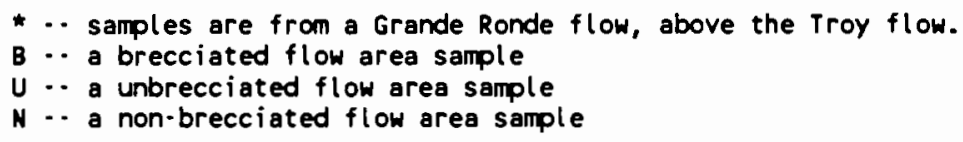

Symbols used in intraflow zones

$$
\begin{aligned}
& \text { CH .- confining walls } \\
& \text { EB -. enclosed breccia } \\
& \text { CP -. convex-up platey jointed } \\
& \text { VZ .. vesicular } \\
& \text { VB .. vesicular bands } \\
& \text { SV - sheared vesicular } \\
& \text { IP . . inclined platy jointed } \\
& \text { BB -. basal chilled pohoehoe }
\end{aligned}
$$


INAA

Broad overall trends in INAA data were indentified between brecciated flow areas and unbrecciated to non-brecciated flow areas. If the concentration of an element within a sample set for any of the seventeen elements analyzed increases towards the base of the flow, the element was considered to be enriched. The element was considered to be depleted if the concentration decreases in the sample set towards the base of the flow. Certain elements were either enriched or depleted from the top of the Troy flow through the base of the flow. Generally, the unbrecciated and nonbrecciated flow areas have similar enrichment or depletion trends towards the base of the Troy flow (Figure 22). In brecciated flow areas, the trends of enrichment or depletion are less pronounced than the trends in unbrecciated or non-brecciated flow areas (Figure 23). A statistical comparison bewteen a brecciated flow area (WR) and a non-brecciated flow area (GC) revealed seven elements have $F$ values equal or greater than the critical value. Ten elements in unbrecciated and non-brecciated flow areas have higher variances than elements in brecciated flow areas (Appendix G).

Non-brecciated and unbrecciated flow areas (GC and EF) have similar transitions towards the base of the Troy flow for particular elements. K, La, Eu, and $\mathrm{Ta}$ are enriched and $\mathrm{Fe}$ and Co are depleted greater than 108 within the Troy flow. Sm is enriched less than 108 (Table VIII). The elements $H f$ and $C e$ are enriched and $T h$ is depleted towards the base the Troy flow, but the overall differences between the concentrations from upper and lower samples within the 


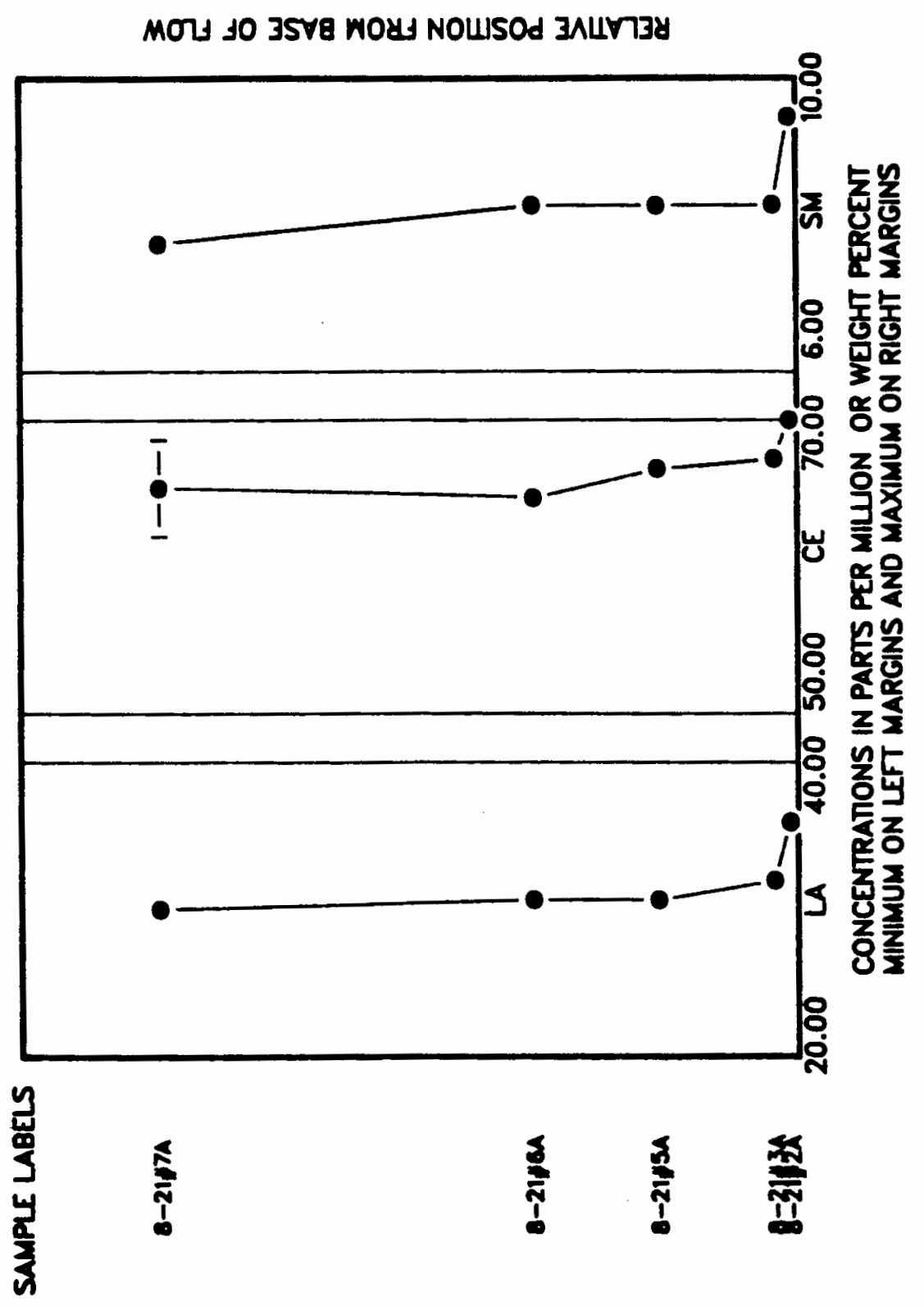

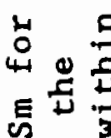

on

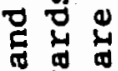

هั

焉

穿要

4 범

ง

웅

40

त

3 엉

-1 54

计

D果的

总 分

- 0 已

() $0^{-1}$ 电

4 更

-

I ${ }^{3}$ \%

त $\frac{2}{4}$

光

点

나요

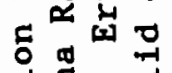

点

๑ 3

㝳息号

(1) 51

용

डु 4 H

40

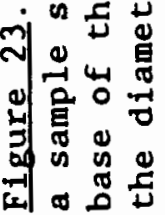




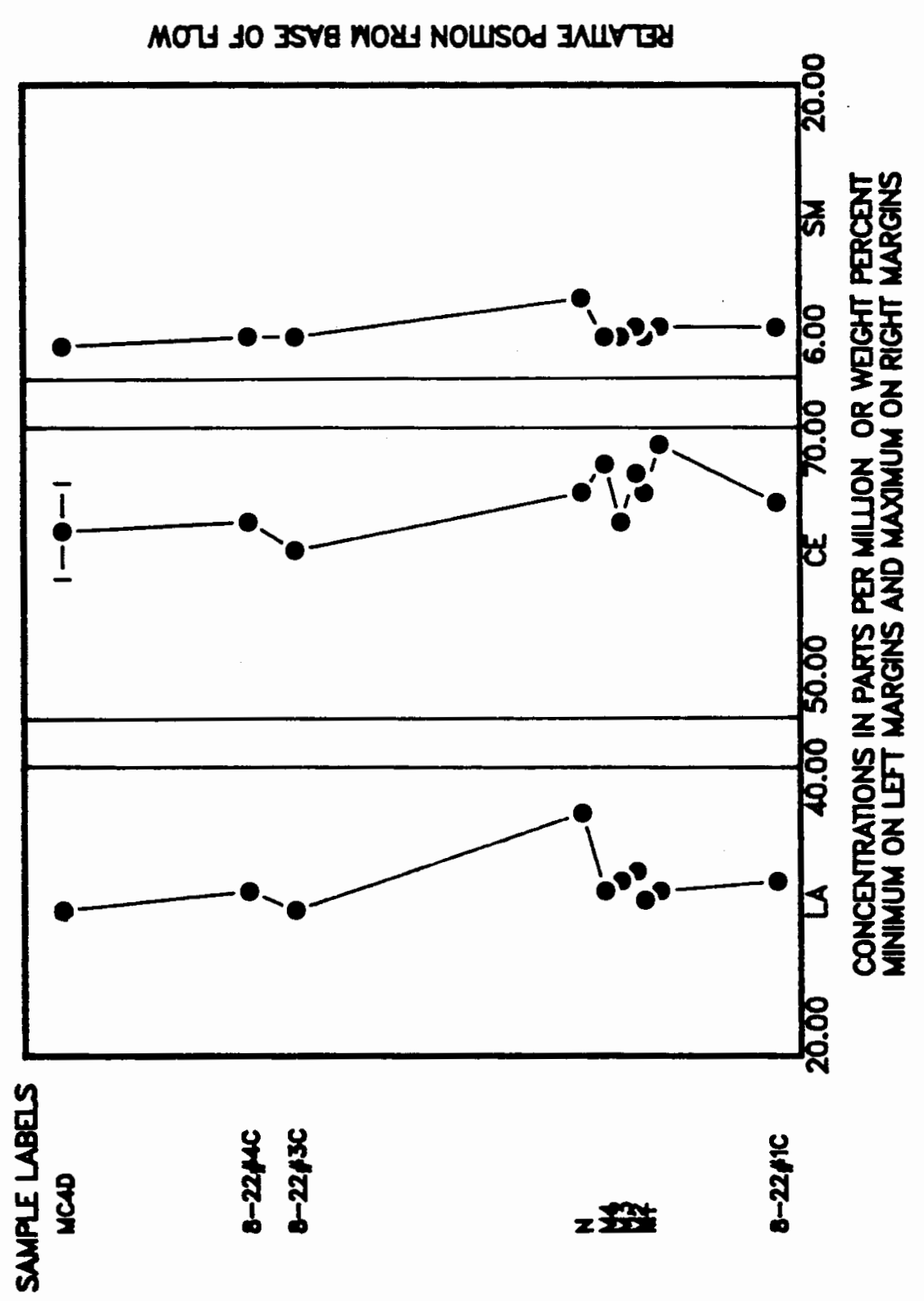

E

可㟧

- Q

\& क स

0 -

욜 들

능 3

4.

$\Rightarrow$ क

(1)

UL

㝳上

。

넝 당

- 보

号

of

o

$0 \stackrel{10}{0}$

03

톡 옹

툐

-

눙

E

부교

$c$ 뇌

언

ज मे

电

E 0

넝 엉

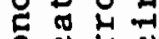

O O 에 0

임

궁

일

光 至

and 40

데 언 분 
TABLE VIII

SUMMARY OF ENRICHED OR DEPLETED ELEMENTS FOR SAMPLE SETS

\begin{tabular}{|c|c|c|c|c|c|}
\hline \multirow[t]{2}{*}{ E lements } & \multicolumn{5}{|c|}{ Sample set label } \\
\hline & GC & EF & UR & Wenaha.C & SC\#1 \\
\hline k & $\mathbf{E}$ & $\mathbf{E}$ & D & $\mathbf{E}$ & \\
\hline La & $\mathbf{E}$ & $\mathbf{E}$ & & d & \\
\hline EU & $\mathbf{E}$ & $\mathbf{E}$ & e & & \\
\hline Ta & $\mathbf{E}$ & $\mathbf{E}$ & & $\mathrm{D}^{\mathrm{B}}$ & \\
\hline $\mathrm{Rb}$ & $\mathbf{E}$ & & D & & \\
\hline Sm & e & $\mathbf{E}$ & & & e \\
\hline $\mathrm{Ba}$ & & $\ddot{\mathbf{E}}$ & D & & \\
\hline $\mathrm{Na}$ & d & e & $d$ & e & $\mathbf{E}$ \\
\hline $\mathrm{Tb}$ & & & $\mathbf{E}$ & & $\mathbf{E}$ \\
\hline Ce & e & $e^{-B^{\circ}}$ & e & d & \\
\hline Hf & $e^{B}$ & e & & & \\
\hline sc & & e & e & & \\
\hline $\mathrm{Fe}$ & D & $\dddot{D}$ & d & & e \\
\hline Lu & D & & & & \\
\hline co & D & D & D & D & \\
\hline Th & d & $d^{B}$ & & & \\
\hline
\end{tabular}

* Enrichment and depletion were calculated by substracting the concentration of an element of the lower sample from the concentration of the upper sample then dividing by the larger of the two sample concentrations. If the lower sample concentration was larger then the trend is considered enrichment and if the upper sample concentration was larger then the trend is considered a depletion.

B The element has a quotient equal to the maximum error of the entire sample set from the INAA analysis.

Symbols:
Enrichment
$>10 \% \cdots \mathrm{E}$
$\leq 10 \% \cdots e$

Depletion

$>10 \% \cdots D$

$\leq 10 \% \cdots d$ 
flow are equal to the maximum error of the entire sample set. In equivalent brecciated flow areas (WR) within the Troy flow, Tb is enriched and $\mathrm{Co}, \mathrm{Ba}, \mathrm{Rb}$, and $\mathrm{K}$ are depleted more than 108 . $\mathrm{Ce}, \mathrm{Sc}$, and $\mathrm{Eu}$ are enriched and $\mathrm{Na}$ and $\mathrm{Fe}$ are depleted less than 10z. Fe, Co, Ce, and Eu have similar transitions in all three types of flow areas towards the base of the Troy flow. The remaining six elements have contrasting transitions of enrichment or depletion towards the base between brecciated and unbrecciated to non-brecciated flow areas (Table VIII).

The sample set Squaw Canyon ( $\mathrm{SC \# 1)}$ from a Grande Ronde flow stratigraphically above the Troy flow was collected within the upper portion of a breciated flow area. The set occurs at an interface between an enclosed body of breccia and the surrounding confining walls. An equivalent set of samples was collected in the upper portion of a brecciated Troy flow, Wenaha.B sample set. Comparisons between these data sets are not as conclusive as in the above three sample sets, because the geochemistry of the Troy flow differs from that of the upper Grande Ronde flow (Figure 24). Generally, few elements show enrichment or depletion greater than 108 towards the base of the flow, which matches the above trend of a brecciated flow area in the Troy flow.

A special sample, 8-22-SC\#2B, was separated from the chips of sample 8-22-SC\#2 that was collected at the interface of the enclosed bodies of breccia within a younger Grande Ronde flow above the troy flow (Squaw Canyon SC\#1 sample set). Reddish-purple-colored chips were selected and analyzed. Concentrations in this special sample 


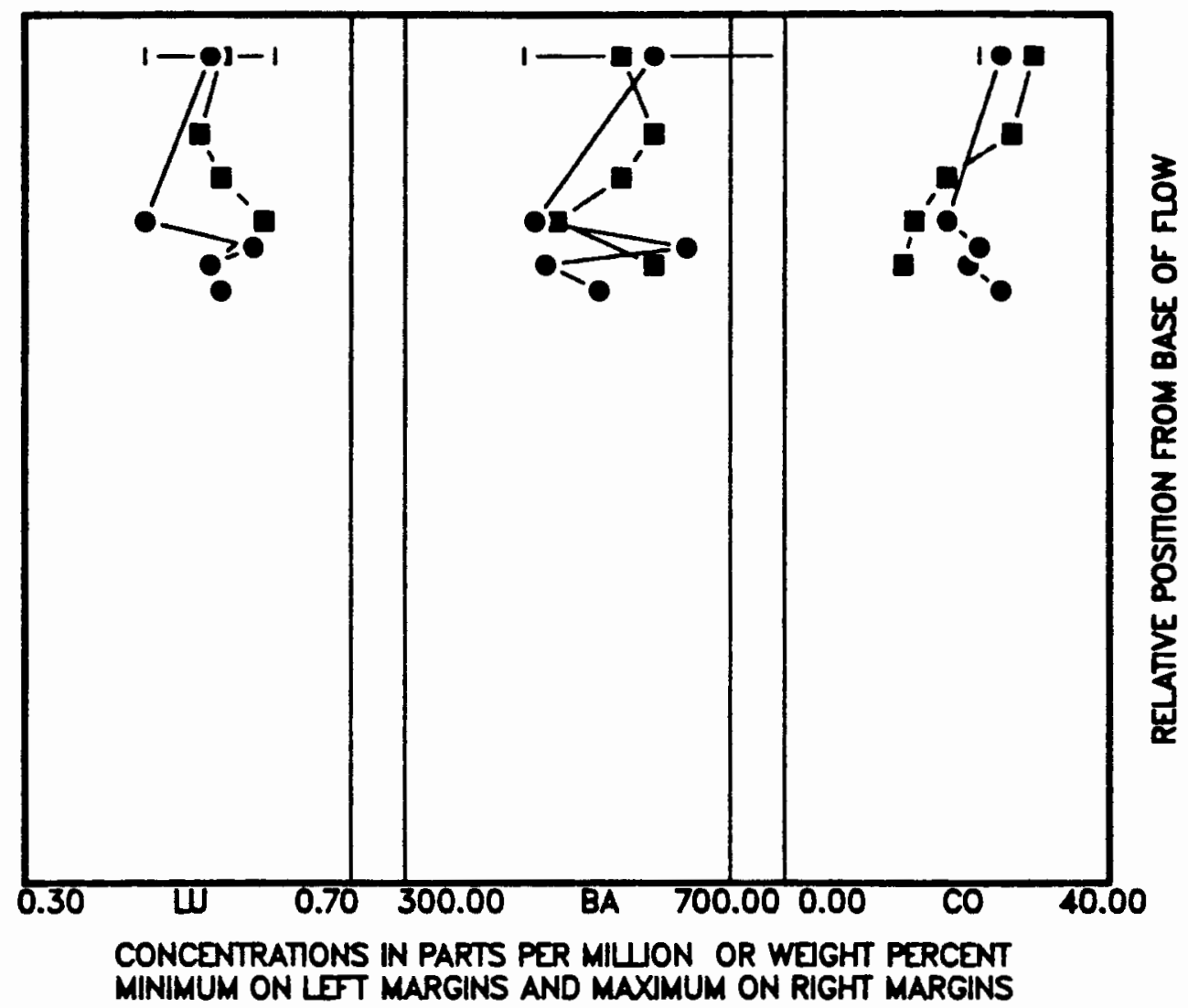

Figure 24. Concentration trends in brecciated flow areas for

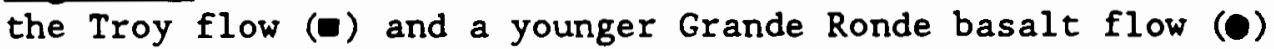
shows similar patterns towards the base of each flow. Error bars are included for each element.

do not conform to the trends established by the surrounding samples (Figure 25). Comparisons within this sample set SC\#l show the special sample has abrupt changes in concentration greater than the maximum error within the sample set (Table IX). In seven out of the seventeen elements, the special sample has either the highest or lowest concentration for that element within the entire sample set. Furthermore, one sample, 8-22-SC\#3, was collected from the enclosed body of breccia immediately above this special sample (Figure 26). 


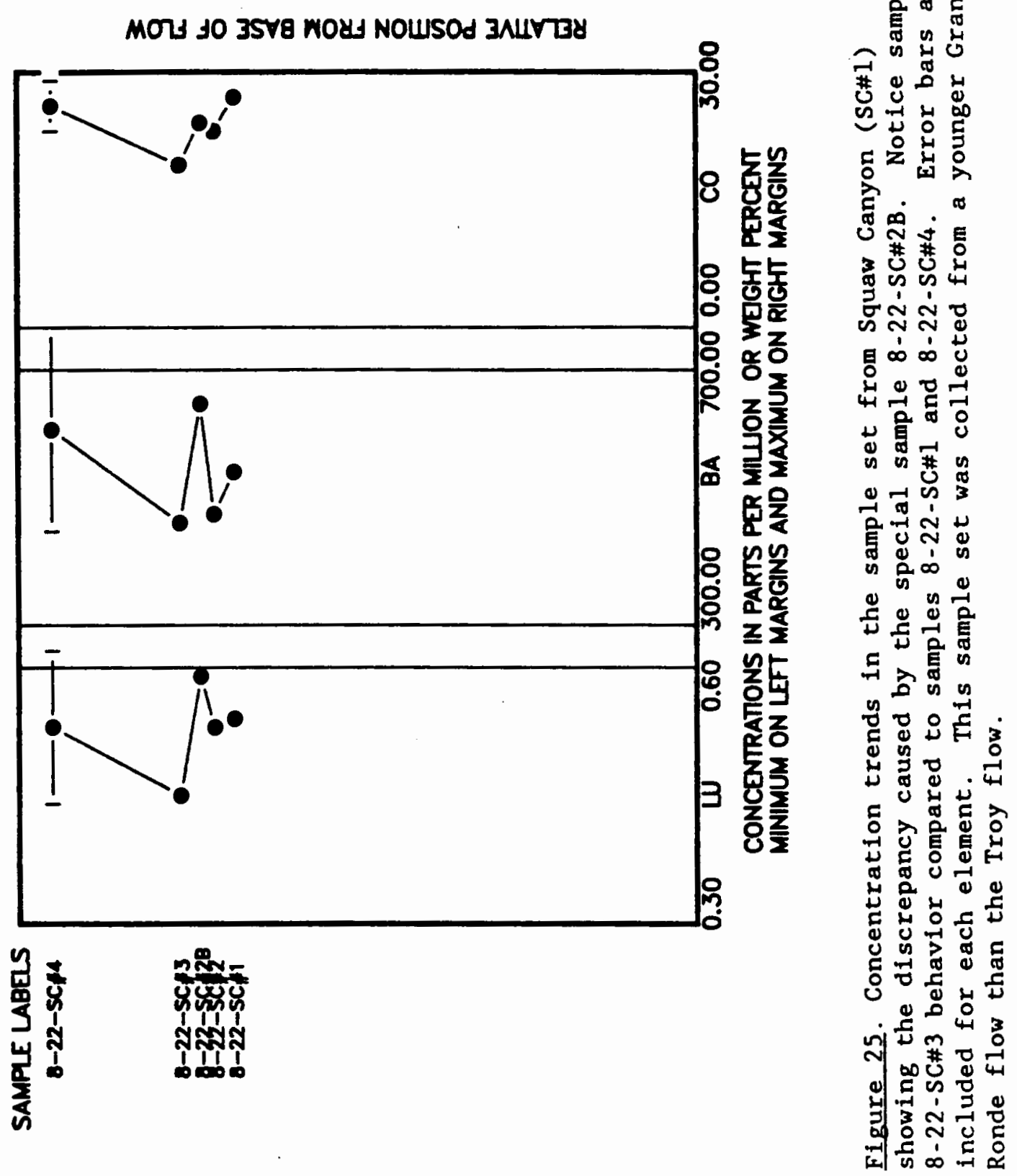


TABLE IX

INAA CONCENTRATIONS, EQUIVALENT DEPTHS, DEPTH IN FION, ELEVATION OF

SAMPLES FROM SAMPLE SET SOUAH CANYON \#1 (SC\#1)

\begin{tabular}{|c|c|c|c|c|c|}
\hline $\begin{array}{l}\overline{\text { SAMPLE }} \\
\text { LABELS }\end{array}$ & $\begin{array}{l}\text { *DEPTH } \\
\text { IN FLOW }\end{array}$ & $\begin{array}{l}\text { SELEVAATION } \\
\text { IN FLON }\end{array}$ & LA & CE & SM \\
\hline $\begin{array}{l}8 \cdot 22 \cdot S C \# 1 \\
8 \cdot 22 \cdot S C \# 2 \\
8 \cdot 22 \cdot S C \# 2 B \\
8 \cdot 22 \cdot S C \# 3 \\
8 \cdot 20 \cdot S C \# 4\end{array}$ & $\begin{array}{r}8(33) 82.00 \\
(30) 72.00 \\
(28) 71.50 \\
(25) 71.00 \\
(6) 0.00\end{array}$ & $\begin{array}{l}2087 \\
2097 \\
2097.5 \\
2098 \\
2169\end{array}$ & $\begin{array}{l}26.90 \\
26.60 \\
25.80 \\
24.00 \\
26.40\end{array}$ & $\begin{array}{l}58.00 \\
56.00 \\
52.00 \\
50.00 \\
56.00\end{array}$ & $\begin{array}{l}7.18 \\
6.83 \\
7.08 \\
6.38 \\
7.10\end{array}$ \\
\hline LABELS & & & EU & TB & YB \\
\hline $\begin{array}{l}8 \cdot 22-S C \# 1 \\
8-22-S C \# 2 \\
8 \cdot 22 \cdot S C \# 2 B \\
8 \cdot 22-S C \# 3 \\
8 \cdot 20 \cdot S C \# 4\end{array}$ & & & $\begin{array}{l}2.32 \\
2.24 \\
2.30 \\
2.01 \\
2.38\end{array}$ & $\begin{array}{l}1.50 \\
1.40 \\
1.20 \\
1.20 \\
1.30\end{array}$ & $\begin{array}{l}5.00 \\
6.10 \\
4.70 \\
4.20 \\
4.90\end{array}$ \\
\hline LABELSS & & & LU & $B A$ & CO \\
\hline $\begin{array}{l}8 \cdot 22 \cdot S C \# 1 \\
8 \cdot 22 \cdot S C \# 2 \\
8 \cdot 22-S C \# 2 B \\
8 \cdot 22-S C \# 3 \\
8 \cdot 20 \cdot S C \# 4\end{array}$ & & & $\begin{array}{l}0.54 \\
0.53 \\
0.59 \\
0.45 \\
0.53\end{array}$ & $\begin{array}{l}550.00 \\
480.00 \\
660.00 \\
470.00 \\
610.00\end{array}$ & $\begin{array}{l}28.00 \\
24.00 \\
25.00 \\
20.00 \\
27.00\end{array}$ \\
\hline LABELS & & & +FEO & $+K_{2} \mathrm{O}$ & HF \\
\hline $\begin{array}{l}8 \cdot 22-S C \# 1 \\
8 \cdot 22-S C \# 2 \\
8 \cdot 22 \cdot S C \# 2 B \\
8 \cdot 22 \cdot S C \# 3 \\
8 \cdot 20 \cdot S C \# 4\end{array}$ & & & $\begin{array}{l}12.45 \\
12.12 \\
12.73 \\
10.89 \\
11.77\end{array}$ & $\begin{array}{l}1.80 \\
1.80 \\
1.70 \\
1.80 \\
2.00\end{array}$ & $\begin{array}{l}5.20 \\
5.20 \\
5.20 \\
5.10 \\
5.40\end{array}$ \\
\hline LABELS & & & $+\mathrm{NA}_{2} \mathrm{O}$ & RB & sc \\
\hline $\begin{array}{l}8 \cdot 22 \cdot s C \# 1 \\
8 \cdot 22-s C \# 2 \\
8 \cdot 22 \cdot S C \# 2 B \\
8 \cdot 22 \cdot S C \# 3 \\
8 \cdot 20 \cdot s C \# 4\end{array}$ & & & $\begin{array}{l}3.44 \\
4.21 \\
3.07 \\
3.09 \\
2.98\end{array}$ & $\begin{array}{l}47.00 \\
47.00 \\
32.00 \\
42.00 \\
60.00\end{array}$ & $\begin{array}{l}36.32 \\
33.19 \\
34.98 \\
31.76 \\
34.71\end{array}$ \\
\hline LABELS & & & TA & $T H$ & \\
\hline $\begin{array}{l}8 \cdot 22 \cdot S C \# 1 \\
8 \cdot 22 \cdot S C \# 2 \\
8 \cdot 22 \cdot S C \# 2 B \\
8 \cdot 22 \cdot S C \# 3 \\
8 \cdot 20 \cdot S C \# 4\end{array}$ & & & $\begin{array}{l}0.49 \\
0.44 \\
0.51 \\
0.29 \\
0.51\end{array}$ & $\begin{array}{l}5.70 \\
5.20 \\
5.30 \\
5.40 \\
5.60\end{array}$ & \\
\hline \multicolumn{6}{|c|}{$\begin{array}{l}8(x x) \text { enclose equivalent depths used to compare concentrations against another sample se } \\
\text { in a hypothetical flow of } 100 \text { feet thick. } \\
\text { * Depth in flow is calculated from field elevations during measurement of stratigraphic } \\
\text { section } \\
\text { s Elevation of the sample within the flow was measured during stratigraphic section or } \\
\text { traverse measurements } \\
+ \text { Oxides concentrations in weight percent (iron is in total } F(0) \text { and remaining } \\
\text { concentrations in part per million }\end{array}$} \\
\hline
\end{tabular}




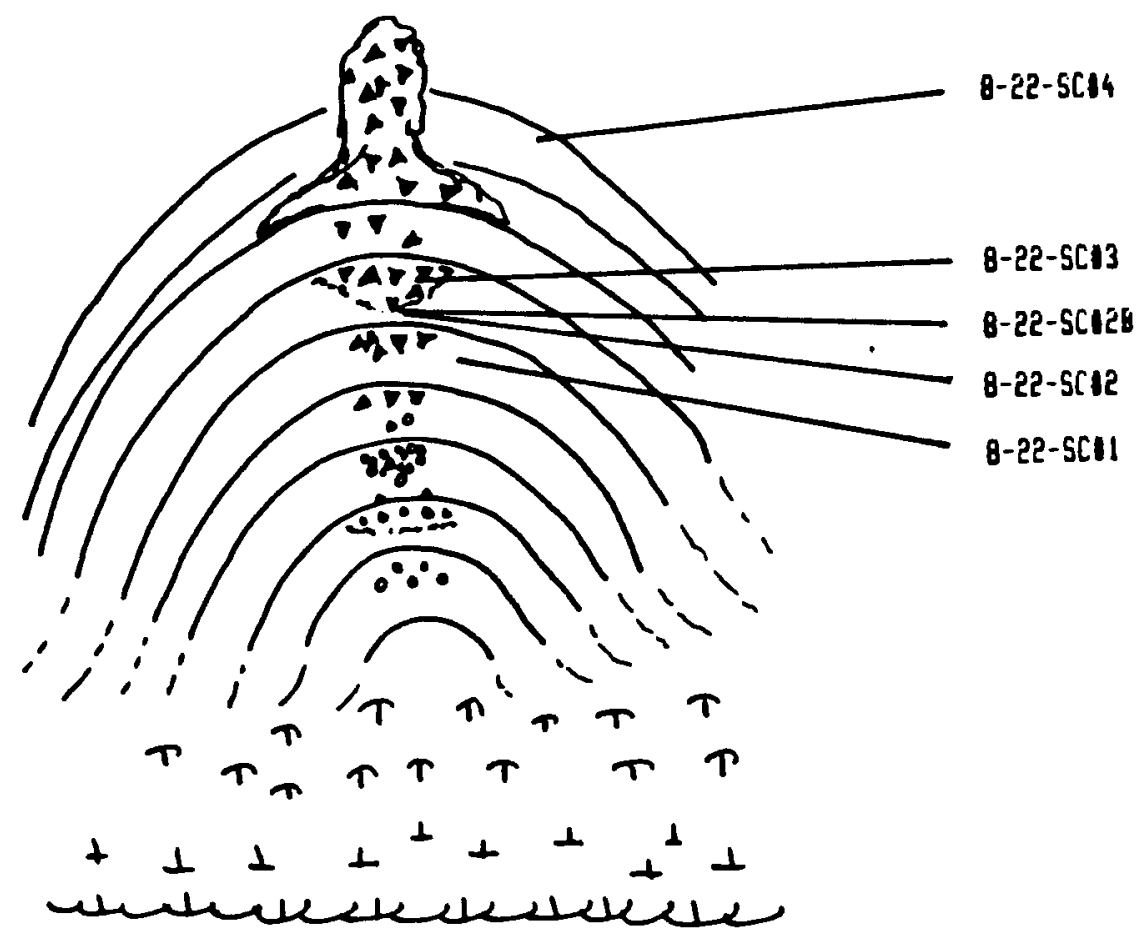

Figure 26. A schematic showing the sample locations for sample set Squaw Canyon (SC\#1) in a younger Grande Ronde basalt flow. Notice the position of samples 8-22-SC\#1 and 8-22-SC\#4 relative to sample 8-22-SC\#3 in the breccia.

Sample 8-22-SC\#3 has the lowest concentration within the entire set for thirteen of the seventeen elements (Table IX). A sample, 8-22SC\#1, was collected in the confining walls immediately below the special sample 8-22-SC\#2B. Sixteen of the seventeen elements, except $\mathrm{Fe}$, have higher concentrations within the confining walls than in the sample collected from the trapped body of breccia. Sample 8-22-SC\#4 was collected from the confining walls near the superjacent contact with the overlying flow and above the special sample 8-22-SC\#2B. Sixteen of the seventeen elements except $\mathrm{Na}$, again have higher concentrations than the concentrations of the 
sample 8-22-SC\#3 (Tab1e IX).

Another sample set, Wenaha.B, was similarily collected across an interface between an enclosed body of breccia and the confining walls in an explosion structure of the Troy flow (Figure 27). The

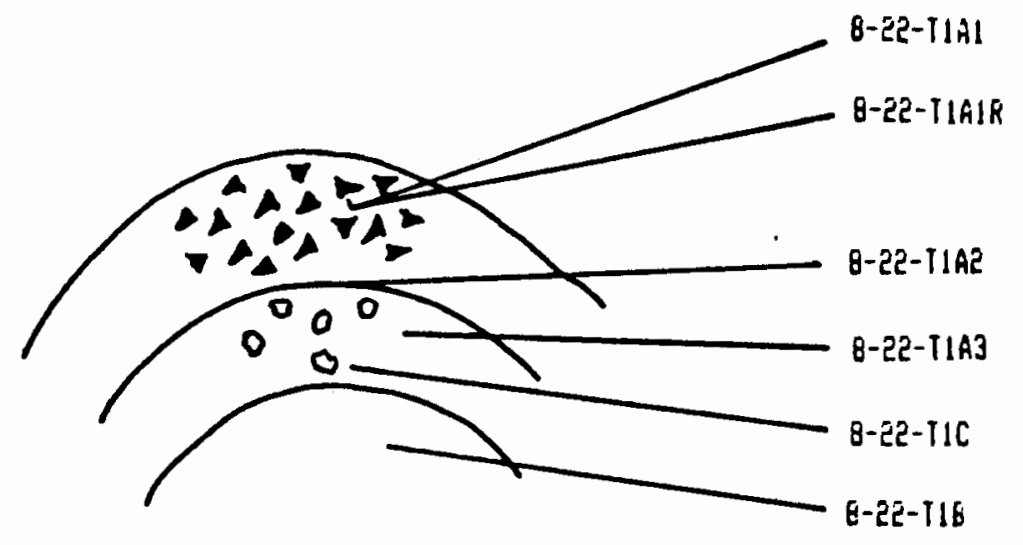

Figure 27. A schematic showing the sample locations for sample set Wenaha. B in the Troy flow collected at the interface between the confining walls and a trapped body of breccia. Notice the positions of each sample relative the breccia sample 8-22-TLAl.

collection site is at the center of an arch formed by the confining walls. At this site, the confining walls contain vesicular clasts. Another special split sample was made from reddish-purple-colored chips of the breccia sample, 8-22-TlAl. This sample, 8-22-TlAlR, has either the highest or lowest concentrations for seven of the seventeen elements: $\mathrm{La}, \mathrm{Sm}, \mathrm{Tb}, \mathrm{Yb}, \mathrm{Hf}, \mathrm{Na}$, and Th (Table X). Comparisons within this entire sample set show an abrupt change in the trends of elements, caused by this special sample (Figure 28). This abrupt change is similar to the those noted in sample set SC\#1. 
TABLE $X$

inAa CONCENTRATIONS, EQUiVALENT DEPTHS, DEPTH IN FLOW, ELEVATION OF

SAMPLES FROM SAMPLE SET WENAHA.B

\begin{tabular}{|c|c|c|c|c|c|}
\hline $\begin{array}{l}\text { SAMPLES } \\
\text { LABEL }\end{array}$ & $\begin{array}{l}\text { *DEPTH } \\
\text { IN FLOW }\end{array}$ & $\begin{array}{l}\text { SELEVATION } \\
\text { IN FLOW }\end{array}$ & La & $\mathrm{Ce}$ & Sm \\
\hline $\begin{array}{l}8-22-T 1 A 1 \\
8-22-T 1 A 1 R \\
8-22-T 1 A 2 \\
8-22-T 1 A 3 \\
8-22-T 1 B \\
8-22-T 1 C\end{array}$ & $\begin{array}{l}1.00 \\
2.00 \\
3.00 \\
4.00 \\
5.00 \\
6.00\end{array}$ & $\begin{array}{l}2200 \\
2199 \\
2198 \\
2197 \\
2196 \\
2195\end{array}$ & $\begin{array}{l}30.40 \\
31.40 \\
30.90 \\
31.40 \\
30.20 \\
30.50\end{array}$ & $\begin{array}{l}62.00 \\
63.00 \\
65.00 \\
61.00 \\
65.00 \\
62.00\end{array}$ & $\begin{array}{l}7.71 \\
7.80 \\
7.97 \\
8.04 \\
7.87 \\
7.77\end{array}$ \\
\hline
\end{tabular}

\section{LABELS}

\section{Eu}

Tb

$\mathrm{Yb}$
8-22-T1A1
8-22-TIAIR
8-22-T1A2
8-22-T1A3
$8 \cdot 22 \cdot \mathrm{T} 1 \mathrm{~B}$
$8 \cdot 22 \cdot \mathrm{T} 1 \mathrm{C}$

2.31
2.33
2.45
2.39
2.45

2.44

1.60

4.50

1.40

1.80

1.60

1.40

1.60

4.50

5.20

5.20

5.10

4.90

LABELS

Lu

Ba

Co
8-22-T1A1
$8 \cdot 22 \cdot$ TIAIR
8.22-T1A2
8-22-T1A3
$8 \cdot 22 \cdot T_{1 B}$
8-22-T1C

$\begin{array}{lll}0.56 & 500.00 & 19.00 \\ 0.63 & 640.00 & 20.00 \\ 0.54 & 630.00 & 23.00 \\ 0.60 & 720.00 & 30.00 \\ 0.68 & 660.00 & 17.00 \\ 0.56 & 550.00 & 24.00\end{array}$

\section{LABELS}

$+\mathrm{FeO}$

$+\mathrm{K}_{2} \mathrm{O}$

Hf
8-22-TIAT
8-22-T1A1R
8.22-T1A2
8-22-TIA3
8-22-T1B
8.22-T1C

11.52

11.39

11.78

11.01

11.27

10.56

$\begin{array}{ll}2.60 & 5.80 \\ 2.40 & 5.70 \\ 2.20 & 6.40 \\ 2.60 & 5.80 \\ 2.00 & 6.00 \\ 2.10 & 5.70\end{array}$

$\bar{Z}(x x)$ enclose equivalent depths used to compare concentrations against another sample set in a hypothetical flow of 100 feet thick.

* Depth in flow is calculated from field elevations during measurement of stratigraphic section

S Elevation of the sample within the flow was measured during stratigraphic section or traverse measurements

+ Oxides concentrations in weight percent (iron is in total Feo) and remaining concentrations in part per million 
TABLE $\times$ CONTINUED

inAN CONCENTRATIONS, EQUiVALENT DEPTHS, DEPTH IN FLOH, ELEVATION OF SAMPLES FROM SAMPLE SET WENAHA.B

\begin{tabular}{|c|c|c|c|}
\hline LABELS & $+\mathrm{Na}_{2} \mathrm{O}$ & $\mathbf{R b}$ & Sc \\
\hline $\begin{array}{l}\text { 8-22-TIA1 } \\
8-22-T 1 A 1 R \\
8-22-T_{1 A 2} \\
8-22-T 1 A 3 \\
8-22-T 1 B \\
8-22-T 1 C\end{array}$ & $\begin{array}{l}3.48 \\
3.75 \\
3.45 \\
3.47 \\
3.47 \\
3.32\end{array}$ & $\begin{array}{l}59.00 \\
54.00 \\
66.00 \\
56.00 \\
66.00 \\
39.00\end{array}$ & $\begin{array}{l}30.07 \\
30.20 \\
31.80 \\
25.05 \\
31.18 \\
30.19\end{array}$ \\
\hline LABELS & $\mathrm{Ta}$ & Th & \\
\hline $\begin{array}{l}8-22-T_{1 A 1} \\
8-22-T_{A} 1 \mathrm{R} \\
8-22-T_{1 A 2} \\
8-22-T_{1 A 3} \\
8-22-T_{1 B} \\
8-22-T_{1}\end{array}$ & $\begin{array}{l}0.46 \\
0.52 \\
0.51 \\
0.37 \\
0.48 \\
0.47\end{array}$ & $\begin{array}{l}6.60 \\
6.20 \\
7.10 \\
6.40 \\
6.80 \\
6.50\end{array}$ & \\
\hline
\end{tabular}

$\bar{Q}(x x)$ enclose equivalent depths used to compare concentrations against another sample set in a hypothetical $\mathrm{flow}$ of 100 feet thick.

- Depth in flow is calculated from field elevations during measurement of stratigraphic section

5 Elevation of the sample within the flow was measured during stratigraphic section or traverse measurements

+ Oxides concentrations in weight percent (iron is in total Feo) and remaining concentrations in part per million

Sample 8-22-T1A2 collected in the confining walls immediately at the interface has the highest concentrations for ten of the seventeen elements. When compared to sample 8-22-TlAl, sample 8-22-TlA2 had higher concentrations for fourteen of the elements, except $\mathrm{Na}, \mathrm{K}$, and Lu.

Within the Squaw Canyon (SC\#1) sample set, samples collected from the confining walls generally increase in concentration for most elements when compared to samples collected from the enclosed body of breccia or the interface bewteen the breccia and the confining walls. Within the Wenaha.B set, similar results were repeated, but for fewer elements. Vesicular pockets or clasts are 


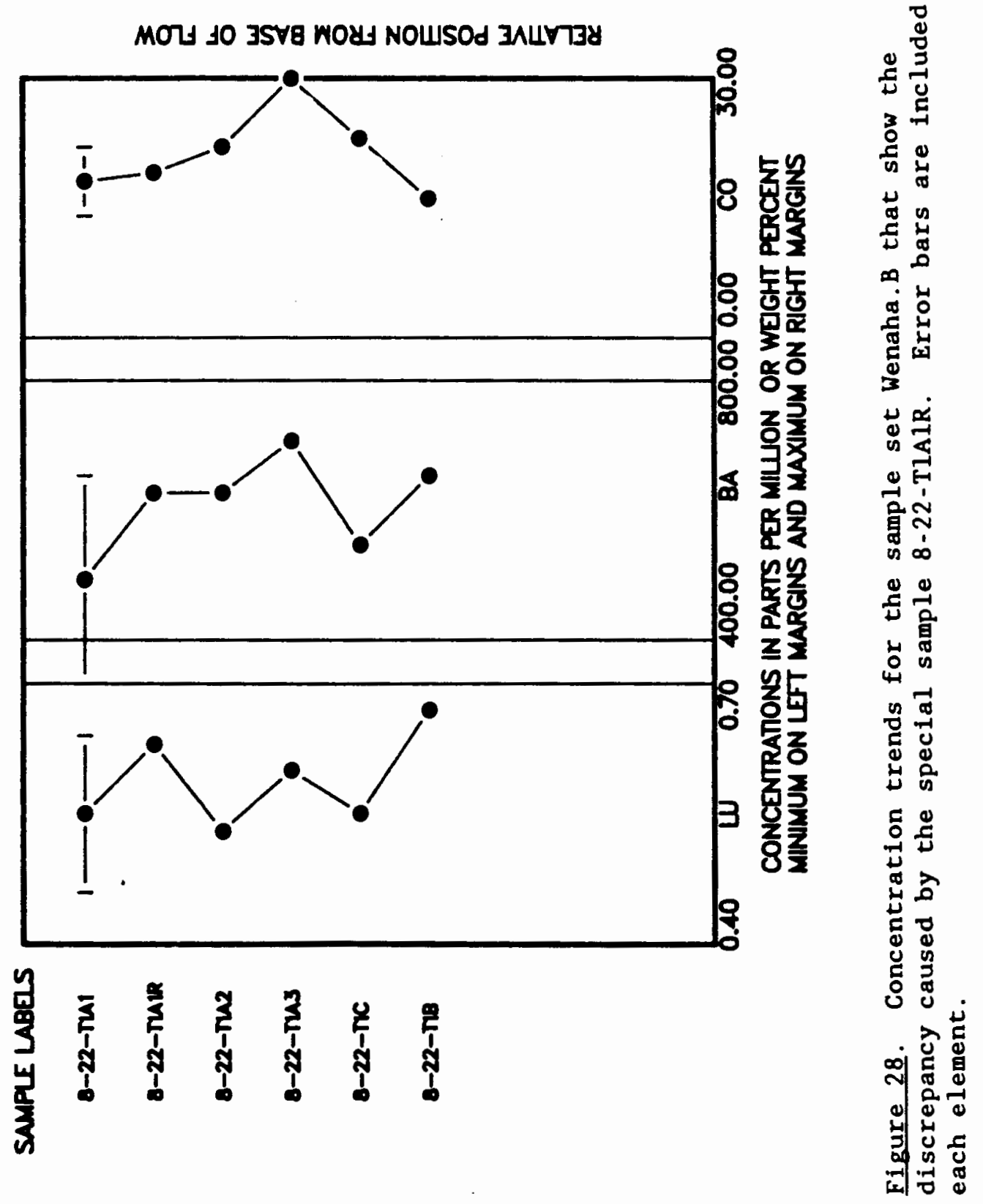


absent from samples collected within the confining walls for the Squaw Canyon (SC\#1) sample set. Vesicular pockets or clasts occur within the samples collected within the confining walls for the Wenaha.B set. The overall geochemistry is slightly different between these two sample sets. The Wenaha.B sample set was collected in the Troy flow, while Squaw Canyon SC\#1 sample set is from an overlying Grande Ronde flow. However, elements La, Ce, Sm, $\mathrm{Tb}, \mathrm{Fe}, \mathrm{Na}$, and $\mathrm{Sc}$ show abrupt changes for both sample sets across or at the interface between the confining walls and the enclosed body of breccia (Table XI).

TABLE XI

SUMMARY OF THE ELEMENTS WHICH CHANGED ACROSS THE INTERFACE FROM THE SPECIAL SPLIT SAMPLE TO THE IMAEDIATE SUBJACENT SAMPLES

\begin{tabular}{cc}
\hline Sample set label & Elements \\
\hline Wenaha.B & La Sm Tb Fe Ma Sc Hf Eu \\
SC\#1 & La Sm Tb Fe Na Sc C Ce Ba \\
\hline
\end{tabular}

\section{Mossbauer}

A sample set from the Wenaha.B site was analyzed by Mossbauer spectroscopy. Mossbauer spectroscopy allowed determination of the oxidation state of iron, $\mathrm{Fe}^{+3}$ or $\mathrm{Fe}^{+2}$, and the mineralogy of the iron-bearing phases in three samples from sample set Wenaha.B. The iron-bearing phases in the Troy flow are pyroxenes (hypersthene, pigeonite, subcalcic, and augite) and opaques (titanomagnetite and 
ilemnite) (Ross, 1978). Sample 8-22-T1Al was collected from an enclosed body of breccia, while samples 8-22-T1A3 and 8-22-T1C were collected in the immediate subjacent confining walls of the explosion structure (Figure 27). Sample 8-22-T1A3 was collected from confining walls that contain vesicular clasts. Results of the Mossbauer spectrum of sample 8-22-TlAl indicate that 708 of the iron present within sample occurs as $\mathrm{Fe}^{+3}$ and $\mathrm{Fe}^{+3}$ is present in hematite (Howard, D.F., personal communication, 1987). Magnetite was indentified in the two samples, 8-22-TIA3 and 8-22-T1C, from the confining walls. Thus the oxidation state of iron changed from $\mathrm{Fe}^{+2}$ in the black confining walls to $\mathrm{Fe}^{+3}$ in the reddish-purple-colored breccia.

$\underline{\mathrm{XRF}}$

Selected samples from brecciated, unbrecciated, and nonbrecciated flow areas within the Troy flow were analyzed by XRF. Samples M, M4, and N (WR sample set) were collected within a brecciated flow area. Samples labelled 8-21\#?A (EF sample set) were collected within an unbrecciated flow area and samples labelled 8-22\#?C (GC sample set) were collected within a non-brecciated flow area. Results indicate samples within the Troy flow have $\mathrm{SiO}_{2}$ concentrations greater than 558 (Table XII). Plots of oxide concentrations versus $\mathrm{SiO}_{2}$ for samples from brecciated, unbrecciated, and non-brecciated flow areas indicate that three samples plot differently from the other samples (Figure 29). Two samples were collected from the basal contacts of first and second cooling units of the Troy flow, $M$ and $N$ respectively, and one 
TABLE XII

XRF DATA FOR CERTAIN ELEMENTS

\begin{tabular}{|c|c|c|c|c|c|c|c|}
\hline SAMPLE & $\mathrm{SiO}_{2}$ & $\mathrm{Al}_{2} \mathrm{O}_{3}$ & $\mathrm{TiO}_{2}$ & $\mathrm{Fe}_{2} \mathrm{O}_{3}$ & Feo & Mno & $\mathrm{CaO}$ \\
\hline $\begin{array}{l}\text { N } \\
\text { M4 } \\
\text { M }\end{array}$ & $\begin{array}{l}56.90 \\
56.22 \\
57.02\end{array}$ & $\begin{array}{l}15.90 \\
15.29 \\
15.76\end{array}$ & $\begin{array}{l}2.69 \\
2.55 \\
2.63\end{array}$ & $\begin{array}{l}2.00 \\
2.00 \\
2.00\end{array}$ & $\begin{array}{r}10.39 \\
10.98 \\
9.49\end{array}$ & $\begin{array}{l}0.14 \\
0.18 \\
0.19\end{array}$ & $\begin{array}{l}5.25 \\
5.37 \\
5.55\end{array}$ \\
\hline $\begin{array}{l}8-21 \# 7 A \\
8-21 \# 6 A \\
8-21 \# 5 A \\
8-21 \# 3 A \\
8-21 \# 2 A\end{array}$ & $\begin{array}{l}55.63 \\
55.67 \\
56.25 \\
55.78 \\
58.55\end{array}$ & $\begin{array}{l}15.08 \\
15.25 \\
15.30 \\
15.08 \\
16.55\end{array}$ & $\begin{array}{l}2.46 \\
2.57 \\
2.61 \\
2.52 \\
2.87\end{array}$ & $\begin{array}{l}2.00 \\
2.00 \\
2.00 \\
2.00 \\
2.00\end{array}$ & $\begin{array}{r}10.26 \\
9.84 \\
10.06 \\
10.25 \\
7.94\end{array}$ & $\begin{array}{l}0.17 \\
0.18 \\
0.18 \\
0.21 \\
0.31\end{array}$ & $\begin{array}{l}6.14 \\
6.40 \\
5.75 \\
6.10 \\
4.56\end{array}$ \\
\hline $\begin{array}{l}8-22 \# 4 c \\
8-22 \# 3 c\end{array}$ & $\begin{array}{l}56.34 \\
55.84\end{array}$ & $\begin{array}{l}15.15 \\
15.16\end{array}$ & $\begin{array}{l}2.48 \\
2.49\end{array}$ & $\begin{array}{l}2.00 \\
2.00\end{array}$ & $\begin{array}{l}9.96 \\
9.94\end{array}$ & $\begin{array}{l}0.23 \\
0.24\end{array}$ & $\begin{array}{l}6.01 \\
6.39\end{array}$ \\
\hline
\end{tabular}

\begin{tabular}{|c|c|c|c|c|}
\hline SAMPLE & Mgo & $\mathrm{K}_{2} \mathrm{O}$ & $\mathrm{Na}_{2} \mathrm{O}$ & $\mathrm{P}_{2} \mathrm{O}_{5}$ \\
\hline $\begin{array}{l}\text { N } \\
\text { M4 } \\
\text { M }\end{array}$ & $\begin{array}{l}1.93 \\
2.56 \\
2.35\end{array}$ & $\begin{array}{l}2.07 \\
2.04 \\
2.04\end{array}$ & $\begin{array}{l}2.22 \\
2.39 \\
2.48\end{array}$ & $\begin{array}{l}0.51 \\
0.43 \\
0.49\end{array}$ \\
\hline $\begin{array}{l}8 \cdot 21 \# 7 A \\
8-21 \# 6 A \\
8 \cdot 21 \# 5 A \\
8 \cdot 21 \# 3 A \\
8 \cdot 21 \# 2 A\end{array}$ & $\begin{array}{l}3.48 \\
3.08 \\
2.84 \\
3.36 \\
1.29\end{array}$ & $\begin{array}{l}1.79 \\
1.94 \\
2.10 \\
1.80 \\
2.90\end{array}$ & $\begin{array}{l}2.54 \\
2.59 \\
2.41 \\
2.45 \\
2.49\end{array}$ & $\begin{array}{l}0.44 \\
0.48 \\
0.48 \\
0.47 \\
0.57\end{array}$ \\
\hline $\begin{array}{l}8-22 \# 4 c \\
8-22 \# 3 c\end{array}$ & $\begin{array}{l}2.64 \\
3.19\end{array}$ & $\begin{array}{l}2.20 \\
1.85\end{array}$ & $\begin{array}{l}2.51 \\
2.48\end{array}$ & $\begin{array}{l}0.48 \\
0.42\end{array}$ \\
\hline
\end{tabular}

Analyzed at Washington State University by P. R. Hooper, 1986.

sample, 8-21-2A, was collected from the basal contact of an

unbrecciated flow area within the Troy flow. These three samples are separate from the remaining sample concentrations in six of ten oxides (Table XII).

Enrichment or depletion trends observed in INAA concentrations from the top of the Troy flow to the base can be applied to the concentrations determined by XRF. Similar behavior is noticed for sample sets EF and WR for both INAA and XRF concentrations. Within 


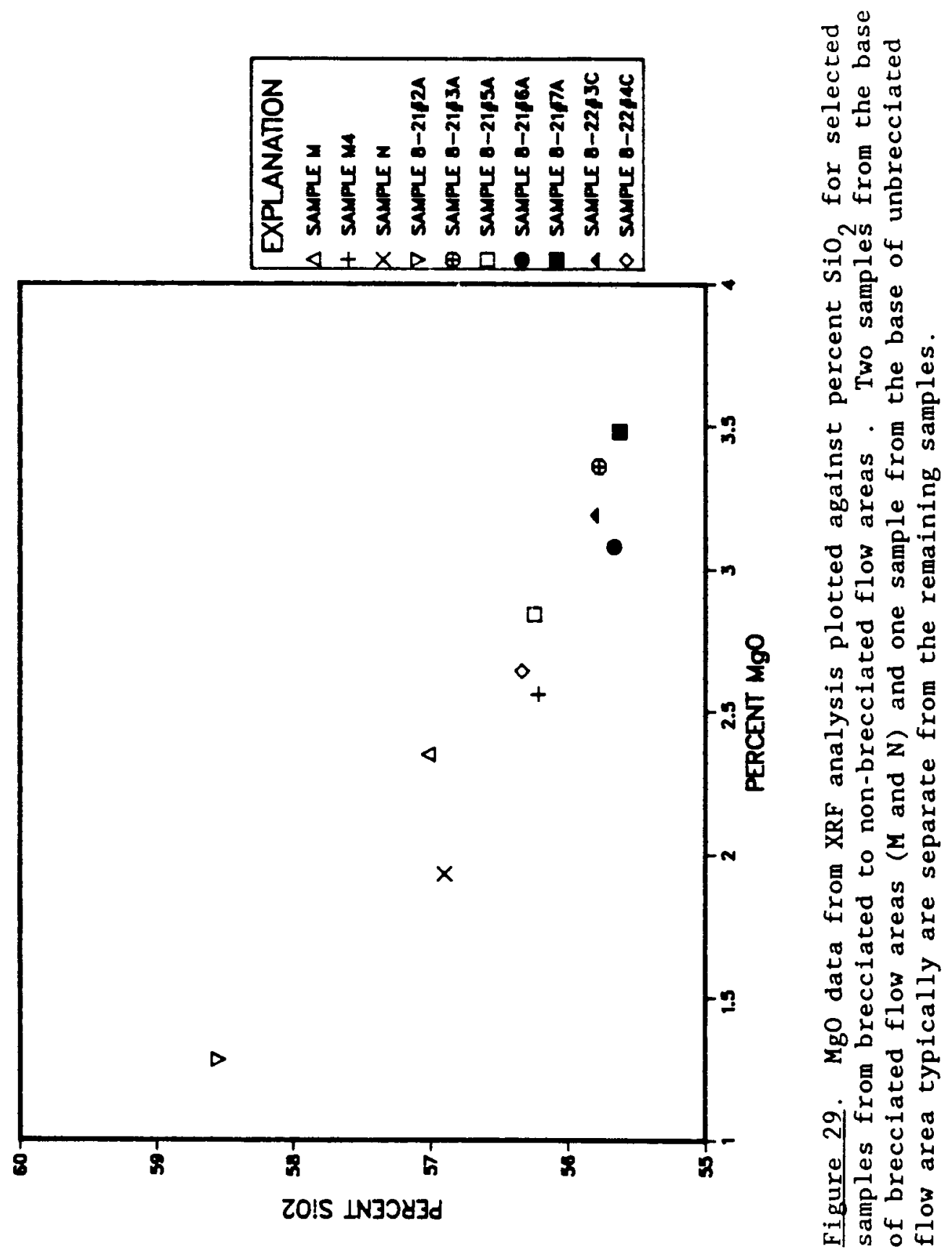


sample set EF, oxides $\mathrm{SiO}_{2}, \mathrm{Al}_{2} \mathrm{O}_{3}, \mathrm{TiO}_{2}, \mathrm{MnO}, \mathrm{K}_{2} \mathrm{O}$, and $\mathrm{P}_{2} \mathrm{O}_{5}$ show enrichment towards the base for an unbrecciated flow area in the Troy flow. Oxides $\mathrm{CaO}, \mathrm{MgO}, \mathrm{Na}_{2} \mathrm{O}$, and $\mathrm{FeO}$ show a depletion trend towards the base. Within sample set (WR), the trends of the XRF data are similar to the trends of the INAA data in brecciated flow areas. However, XRF concentrations for sample set WR are less conclusive since only three samples were analyzed. 
CHAPTER IV

\section{DISCUSSION}

The objectives of this study were to describe and characterize the explosion structures and determine the mechanisms of development of these features. Explosion structures within brecciated flow areas of the Troy flow are characterized by differences in 1) intraflow petrographic textures, 2) jointing patterns, 3) geochemical trends, and 4) stratigraphic relationships from unbrecciated to non-brecciated flow areas. The mechanism of development of explosion structures are related to these four differences. This discussion will first deal with the development of the petrographic textures within the intraflow zones between brecciated to non-brecciated flow areas. The timing and development of the jointing patterns within an explosion structure will be discussed next followed by the geochemical trends. Stratigraphic relations and mechanisms of development of explosion structures will be discussed together, because of their interdependence.

The textures within brecciated flow areas are complicated by the intraflow zones developed in the two cooling units. Intraflow petrographic textures vary considerably between unbrecciated to nonbrecciated flow areas to brecciated flow areas. Generally, unbrecciated and non-brecciated flow areas have predominantly 
intergranular textures in flow interior zones, whereas brecciated flow areas have textures ranging from vitrophyric to intersertal to poorly developed intergranular. The textures of the groundmass in unbrecciated or non-brecciated flow areas indicate that during crystallization microlites of plagioclase and clinopyroxene and intersertal opaques were formed. In brecciated flow areas, crystal growth was inhibited and the proportion of glass is high.

Development of textures containing glass have been described as an effect of rapid cooling or supercooling (Cox and others, 1984; Williams and others, 1982). Two sets of physical controls operate during the crystallization process: 1) externally imposed variables governing the cooling process are time and temperature, and 2) thermodynamic properties of participating phases. Thermodynamic properties include characteristics involving the composition of the melt, degree of consolidation (viscosity), and chemical kinetic processes such as chemical reactions, crystal growth, and nucleation.

Gibb (1974) investigated factors controlling the crystallization of plagioclase from a sample of Picture Gorge Basalt. He reported the ability of the melt to crystalize plagioclase depended upon the degree of supercooling and the duration of the experiment. Supercooling is dependent largely on the composition and the nature of the liquidus phases. Lofgren (1983) argued that textures comparable to those produced by varying cooling rates can be produced by varying the kind and density of nuclei in a melt. These nuclei are trapped in cavities of 
refractory impurities. He concluded that plagioclase crystallization was preceded by heterogeneous nucleation. Rock textures are defined by the plagioclase growth habits and are, in turn, controlled by heterogeneous nucleation. The abundance of plagioclase crystals in the experiments was controlled by 1) the composition and density of the nuclei, and 2) the cooling rate.

Kirkpatrick (1977) investigated nucleation and growth of plagioclase during crystallization in two Hawaiian lava lakes. He determined nucleation occurred heterogeneously on previously existing crystals and was primarly controlled by the rate of cooling. Rapid cooling rates produced glomero-microphenocrysts to microlites and interpenetrating crystals. Glomero-microphenocrysts and interpenetrating crystals (cross-shaped and skewed crosses of plagioclase and clinopyroxene) occur within the intraflow zones of brecciated to non-brecciated flow areas in the Troy flow. The Grande Ronde flow above the Troy flow contains similar crystals. This Grande Ronde flow was sampled ( $\mathrm{SC \# 1}$ sample set) and was approximately $50 \mathrm{~m}$ thick. Thus the rate of cooling was rapid within the Troy flow and the Grande Ronde flow above the Troy flow.

The rate of cooling controls the composition and the size of groundmass plagioclase and the amount of associated glass (Hoffer, $1966 ; 1970)$. The An contents of the microlitic plagioclase within brecciated to non-brecciated flow areas of the Troy flow do not significantly differ from each other. The amount of glass and the size of microlites change between the intraflow zones within brecciated flow areas and between brecciated to non-brecciated flow 
areas. The abundance of glass is high within the basal chilled pahoehoe zone of both cooling units and upward from the convex-up platy jointed zone within the second cooling unit of the Troy flow. Overall, the amount of glass increases and the size of microlitic plagioclase decreases from non-brecciated to brecclated flow areas.

Crystal size is determined by both growth rate and nucleation density (Dowty and others, 1974). If the growth rate is constant and nucleation rate is rapid, crystals are smaller; if the nucleation occurs continuously at a constant rate and the growth rate is rapid, crystals are smaller. The rates of nucleation and growth must be greater in brecciated flow areas than in unbrecciated to non-brecciated flow areas, since the size of microlitic plagioclase decreases in brecciated flow areas. Therefore, various stages of crystallization can be related by the size and the composition of the groundmass plagioclase and the amount of associated glass.

Walker and others (1976) investigated the crystallization history of a sample of lunar picritic basalt. They reported the phases crystallized in the order olivine, chromium spinel, pyroxene, plagioclase, and ilmenite during equilibrium crystallization.

Ilmenite and plagioclase reversed their order of appearances and silica crystallizes in the groundmass during controlled cooling experiments. Cooling rates greater than $10^{4} \mathrm{C} /$ hour produce vitrophyric textures in experimental samples.

The proportion of glass in unbrecciated and non-brecciated flow areas is lower than in brecciated flow areas within the Troy 
flow. The lower amount of glass suggests the Troy flow in unbrecclated and non-brecclated flow areas crystallized under quasiequilibrium conditions, while crystallization in brecciated flow areas crystallized under non-equilibriun (supercooled) conditions. Ross (1978) plotted the abundance of plagioclase against opaques plus glass and the abundance of clinopyroxene against opaques plus glass for the Troy flow. Plagioclase and clinopryoxene curves when projected to 0.08 intersect the glass plus opaques axis at $100 \%$ and 968 respectively. He concluded that both plagioclase and clinopyroxene began crystallizing early and plagioclase began slightly earilier. Similar plots have been prepared by Swanson (1967) for Grande Ronde Basalt and he reported near simultaneous crystallization of clinopyroxene and plagioclase in these flows.

Ross (1978) argued that the oscillatory zoning of the microphenocrysts and phenocrysts of plagioclase was produced during crystallization just prior or during eruption of the Troy flow. Vance (1962) concluded oscillatory zoning within plagioclase crystals occurs when plagioclase crystallizes before or after the release of volatiles from a flow. Microphenocrysts are more abundant near the basal contacts of brecciated, unbrecciated, and non-brecciated flow areas than within the overlying intraflow zones. This greater abundance supports early crystallization of plagioclase and subsequent clinopryoxene. Ross (1978) concluded the formation of the groundmass occurred following the extrusion of the Troy flow. Crystallization within basalt is affected by stirring within the basalt during flow and by the cooling rate (Kouchi and others, 
1986). Stirring greatly increases the nucleation rate and changes the morphology of crystals when the undercooling is greater than $45^{\circ}$ c. Under these conditions, crystals of plagioclase and clinopyroxene are small and adopt acicular morphologies in hyalopilitic textures. The intergranular textures in unbrecciated and non-brecciated flow areas would not result from the influence of stirring from flow or mixing and a high cooling rate. However, the textures in the intraflow zones of an explosion structure within the Troy flow may have resulted from mixing during the upward release of water/steam and/or volatiles and possibly a higher cooling rate.

In this study, primarily the Troy flow of the Grande Ronde Basalt was investigated. The physical properties within the flow should be fairly similar from one location within the study area to another location. Iateral chemical variations within flows of Grande Ronde Basalt are slight (Meyers and Price, 1979). The initial emplacement temperature of the Troy flow should be similar for all locations. Lava temperatures varied little for $10 \mathrm{~km}$ downstream from the vent during the 1984 eruption of Mauna Loa (Lipman and Banks, 1987). The cooling rates and overall composition of the Troy flow should be the same unless the system is perturbed such as in brecciated flow areas. Therefore, cooling rates and/or composition properties must have differed to produce the textures observed in brecciated, unbrecciated, and non-brecciated flow areas.

Vitrophyric and intersertal textures occur in the basal intraflow zones of the Troy flow, in brecciated to non-brecciated flow areas. These textures are probably due to the rapid cooling 
rate adjacent to the relatively cold subjacent topography. A lack of nuclei in the base of the flow did not influence the nucleation process that resulted in these textures. The abundance of nuclei is related to the composition. Geochemical differences do exist through the vertical profile of the Troy flow within unbrecciated to non-brecciated flow areas. These differences should be present at all locations. The number and denisty of nuclei should be similar at each of the three kinds of flow areas. The composition of the Troy flow would have to rapidly change at each location for the number and denisty of nuclei to play a deciding role influencing where explosion structures are located. Rapid composition changes are unlikely from one location to another location within the Troy flow.

The modal abundance of microphenocrysts of clinopyroxene and particularly plagioclase differ sharply from brecciated to nonbrecciated flow areas. Modal abundances of microphenocrysts have been linked to pre-eruption water content of the magma (Anderson, 1973). Desai and Anderson (1974) have suggested that the size, shape, number, and volume of plagioclase microphenocrysts in the crust of a basaltic lava change very little, while the flow is near the source. However, the distribution of microphenocrysts in brecciated flow areas fluctuates strongly among the intraflow zones. While in unbrecciated to non-brecciated flow areas, the abundances of microphenocrysts remains fairly constant. The discrepancy of modal abundances of microphenocrysts in brecciated flow areas may be related to the formation of an explosion structure and the intraflow 
textures.

Textures within the intraflow zones of an explosion structure can be grouped into three major catagories: vitrophyric, intersertal, and banded. Vitrophyric textures are observed in the basal chilled pahoehoe base, of both the first and second cooling units. Intersertal textures occur in the other zones of the first cooling unit and in similar zones of the second cooling unit.

Banded textures are observed in the convex-up platy zone, in the basaltic arms of the confining walls, and in the enclosed bodies of vesicular clasts and pockets and in the eclosed bodies of breccia of an explosion structure. Banded textures can consist of alternating bands to swirled layers of differently textured basalt. Individual bands or layers are composed of textures that range from vitrophyric through intergranular.

These contrasting but intimately interlayered textures within the bands or layers indicate an abrupt difference in the crystal growth behavior from a vitrophyric-type band or layer to an intergranular-type layer. These contrasting types of texturedbasalt could have 1 ) resulted from stirring during the formation of an explosion structure, 2) resulted from a rapid change in cooling rates, 3) rapid degassing of the volatiles within the flow or 4) been brought together and mixed from separate source areas within the flow during formation.

Stirring of basalt and high cooling rates cause small crystals of plagioclase and clinoproxene to form in a hyalopilitic texture (Kouchi and others, 1986). The vitrophyric to intersertal bands or 
layers in an explosion structure could have resulted from these conditions. However, the intergranular bands or layers would need slightly different conditions to produce the more crystalline groundmass. These bands or layers of different textured basalt are extremely thin. The stirring process and cooling rates would have to operate on an extremely small scale to produce these different textured bands or layers immediately adjacent to each other.

Microphenocrysts and microlites within the different textures are aligned parallel to the boundaries between each band or layer. This alignment suggests these crystals were formed earlier than the movement and then aligned by shear movement. Vesicle tears within the intergranular textures are aligned nearly perpendicular to the boundaries. These vesicle tears probably resulted from movement between the different bands or layers and a higher viscosity within the intergranular-textured band or layer, since vesicle tears are not present in other textured bands or layers. Viscosity is a function of temperature, composition, and crystal content (Shaw and others, 1968; Shaw, 1969; 1972). A higher viscosity within the intergranular bands or layers may have been affected by the greater crystalline content of the intergranular bands or layers. Thus the stirring process is not a reasonable explanation for the crystalization of these interlayered bands.

However, the crystallization process operated differently within each contrasting type of band or layer. The transition from a vitrophyric-type of basalt to a intergranular-type, for example, would have to have occurred often in less than a millimeter. The 
transition would have involved an abrupt change of cooling rates or a sudden increase or decrease in the number of nuclei present in the flow. The probability of sudden transition in cooling rates does not seem very likely, since unbrecciated and non-brecciated flow areas show a gradational transition of textures from the base to top of the Troy flow.

Furthermore, the swirled, twisted, pinched and swelled nature of some contrasting bands or layers implies a transition in cooling rates from vitrophyric-type to intergranular-type. The transition in cooling rates would have to be parallel to the pattern of the bands or layers. Bands can occur in patterns where the individual bands are bent back on each other which would imply the transition in cooling rates does the same.

Rapid degassing of the volatiles within the Troy flow could have caused an upward movement of basalt if the upper crust of the flow were to break (Figure 30). The release of pressure, from fracturing of the crust may initiate degassing and an upward movement of volatiles towards this fracture. With depressurization of the flow at the vicinity of the fracture, the separation of gas undercooled the lava without actually lowering the lava temperatures, but initiated crystallization. Similar depressurization from the small volatile loss and subsequent rapid crystallization have been argued to cause vitrophyric textures within Hawaiian lavas (Lipman and Banks, 1987).

The abundance of vesicles on the first cooling unit of the Troy flow may have been caused by the presence of volatiles within 

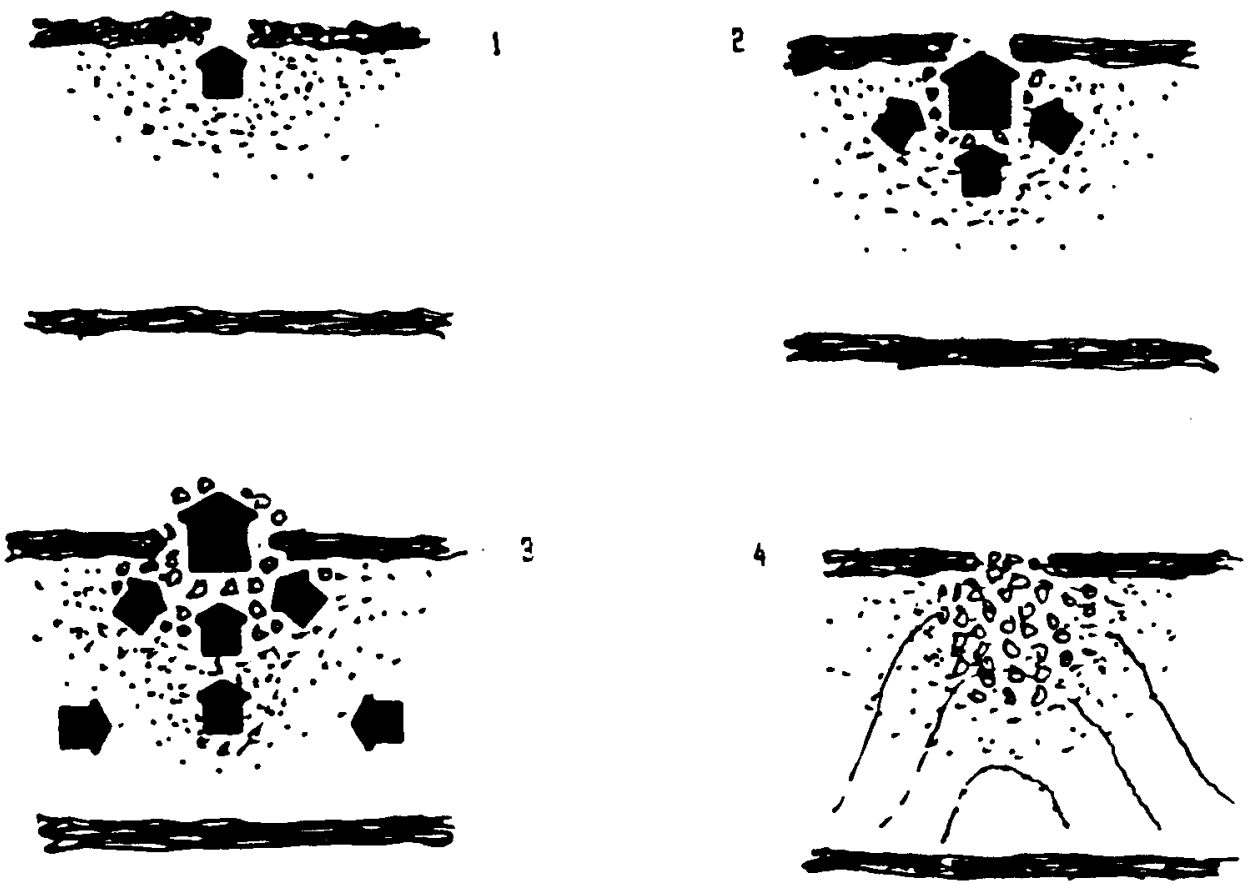

Figure 30. The crust fractures and the release of pressure initiates degassing (1). Degassing increases and movement of volatiles towards the fracture from adjacent areas (2). Crystallization is initiated from the loss of volatiles and fragmentation results from the rapid degassing of volatiles (3). An explosion structure is formed surrounded by a halo of vesicles (4).

the flow. If these volatiles occurred in the second cooling unit as well and fractures occur in the upper crust, the upward release of volatiles may be sufficient to cause rapid crystallization resulting in vitrophyric textures. However, the entire area adjacent to the fracture would be affected similarly by the release of volatiles. The subsequent rapid crystallization from volatile loss should result in vitrophyric textures near the fracture and these textures should grade into more crystalline textures away from the fracture. The banded vitrophyric and intergranular textures that occur within 
the confining walls of the Troy have typically sharp abrupt boundaries. Vesiculation should gradually increase towards the fracture, because the volatiles would move towards the fracture (Figure 30). Vesicles tears occur within the intergranular bands or layers of the confining walls of the Troy flow and are probably the result of movement rather than release of volatiles.

The most reasonable explanation of the bands or layers of vitrophyric and intergranular-textured basalt infers a mixing process that involves a transfer upward of viscous vitrophyric to intersertal-textured basalt during the formation of an explosion structure. Possible source areas for vitrophyric and intersertaltextured basalt during the formation are the subjacent and lateral basal zones of the second cooling unit. Additional transfer involves movement inward of more crystalline material from the adjacent basalt during formation of explosion structures. Textures of several samples from the confining walls or basaltic arms indicate movement of material, because microphenocrysts and microlites of plagioclase and clinopyroxene are arranged parallel to the boundaries between the contrasting textured-types of basalt. Pilotaxitic textures are indicative of movement parallel to the alignment of the crystals (Williams and others, 1982).

Formation of an explosion structure would occur after the initial crystallization of the basalt, but before the basalt was solidified completely. Vesicles were trapped in place in the growing crust of Makaopuhi Lava Lake, Hawaii at temperatures of less than $1,070^{\circ} \mathrm{C}$ (Wright and Okamura, 1977). Similarly vesicular 
clasts and pockets in an explosion structure could have stopped rising upward at approximately this same temperature, $1,070^{\circ} \mathrm{C}$. Initial crystallization of basalt already had begun, because of the bands or layers of intersertal to poorly developed intergranular textures observed in thin sections.

Sample 8-22-SC\#1 contains the vitrophyric to intergranular textures, but was collected from a steeply dipping enclosing basaltic arm. Microphenocrysts and microlites are arranged parallel to the boundaries of the bands or layers. The path of movement within the flow inferred from the textures of this sample observed in thin section would be very steeply dipping to vertical. Thus the textures were not formed by the normal movement parallel to the base of a flow, but by upward movement within the flow. Sample MC-4D was collected even farther upward in a brecciated flow area near the superjacent contact with the overlying flow. Textures from this sample indicate, by the swirling nature of the contrasting vitrophyric to intergranular textured-layers of basalt, that mixing occurred in the upper portion of the Troy flow.

Sample 8-20\#4 has textures that dramatically emphasize the mixing and fragmentation process during formation of explosion structures. Sample 8-20\#4 was collected from an enclosed body of breccia in the vesicular clasts/pockets zone. Petrographic textures range from vitrophyric to intergranular. Vesiculation within each texture type is different and the vesiculation is also different between areas of similar texture types as well. Within the individual bands or layers, vesicle tears are observed adjacent to 
the boundaries between different textural types. Orientation of the vesicle tears suggest the band in which the vesicles are found was slightly more viscous than the adjacent band during development of the bands. Some bands of intergranular texture grade inward to a fine brecciated core that includes millimeter sized fragments.

In conclusion, the contrasting bands or layers can not be reasonably explained by a change in cooling rates or stirring (insitu) on a millimeter scale. A difference in the composition and density of nuclei that influenced crystallization seems more likely. Movement of material can be inferred from the parallel alignment of the microphenocrysts and microlites found within samples of an explosion structure. A mixing process brought the contrasting types of textures together. Fragmentation processes can be observed in samples from the vesicular clasts/pockets zone in the second cooling unit of the Troy flow.

Overall jointing patterns of an explosion structure has been compared to an arch consisting of concentric layers surrounding a central spine (Orzol and Cummings, 1986a; 1986b). A single joint trace can be followed from the peripheral margin of an explosion structure to the center of an arch. The joint trace is nearly vertical at this point and tilts to horizontal at the center of the arch. Petrographic textures within the confining walls indicate the direction of movement was parallel to these joint traces. The alignment of the boundaries of contrasting textures, where present, and the alignment of the microphenocrysts and microlites within the textures are also parallel to these joint traces. 
In the lower portion of an explosion structure, surface textures resembling small ripples were observed on joint traces. The locations of these ripple-like textured rocks occur within the confining walls where the rock consists of multiple layers. These surfaces may have formed from differential movement between individual layers in the lava as each was sliding past the other during the formation process of an explosion structure. The surfaces of each layer would have been viscous in order for the deformation to occur along the surface. Inclination of these layers is parallel to the joint system within an explosion structure. Joints in the vesicular clasts/pockets zone and at the center of the arch, pinch and swell around a chaotic arrangement of plates. Plates are not arranged in a uniform pattern, but vary in size and ordering. Each plate is composed of welded fragments. If the basalt was still viscous during the formation, this fragmention could have occurred from differential movement with later welding of fragments into plates. The pinching and swelling of the joints may be another indication of continued movement during the formation process after the fragments were welded into plates. Each plate has surface textures resembling small ripple-like marks. The surface ripples may have resulted from differential movement between adjacent plates. These surface features suggest that movement continued after the fragments were welded into plates during the formation of an explosion structure.

The basal zones of the second cooling unit are platy jointed, but jointing grades upward to form convex-upward plates. The 
convex-upward jointing is situated directly below the central spine of an explosion structure. Away from the central spine area, joints are no longer convex-up. Myers and Price (1979) argued that the origin of platy joints is related to emplacement and primary cooling and perhaps enhanced by later deformation. Clearly, if deformation enhances platy jointing, a reasonable mechanism for the development of convex-up plates occurred during the formation of an explosion structure. Platy jointing has been proposed to occur after the major vertical cooling joints have formed (Holmgren, 1968). The major vertical joints in brecciated flow areas are in the form of an arch. The arch shape of this joint pattern clearly contrast to the form of an entablature or colonnade (Myers and Price, 1979).

Since the cooling fronts influence the joint location, the orientation of a single joint trace would imply the direction towards the cooling fronts for a hypothetical flow (Degraff and Audin, 1987). Cooling fronts are generally parallel to the upper and lower surfaces of a flow when entablature and colonnade jointing are formed. If the cooling fronts moving through an explosion structure parallel the joint traces, then the cooling fronts would have the arch shape of the confining walls. A reasonable alternative would be the joints formed as the basalt was still slightly moving upward. This upward movement of the basaltic material, greatest at the center of the arch could explain the arch shape of the joint traces. Deformation that caused the ripplemarks on the surfaces of the joint traces occurred during the latest upward movement of basalt. 
Clearly, the jointing pattern of an explosion structure suggests movement of basalt upward during formation. Possible shearing and fragmentation occurred at the center of the concentric layers of the confining walls, because plates consist of welded fragments. Movement between still viscous plates and layers caused deformation that resulted in ripple marks on surfaces of the plates and joint traces. Joints formed before final movement in the formation process and resulted in the arch shape of an explosion structure.

Movement and mixing during the formation of explosion structures may explain the vertical profile of the concentration of major and trace elements within the Troy flow. The vertical profile of geochemical concentrations within brecciated flow areas differ from those that occur within unbrecciated and non-brecciated flow areas (Cummings and others, 1987). Unbrecciated and non-brecciated flow areas have similar profiles towards the base of the Troy flow. Concentration of certain elements increase (enrichment) or decrease (depletion) towards the base of the Troy flow. The trends of enrichment or depletion towards the base of the Troy flow within brecciated flow areas are less pronounced than within the other flow areas.

The factor influencing trends may be the mixing of basalt of different textures. As the explosion structure is formed, basalt is drawn inward and moved upward then mixed within the different intraflow zones of the explosion structure (Figure 31). This mixing process could lead to weakening of the vertical patterns of 

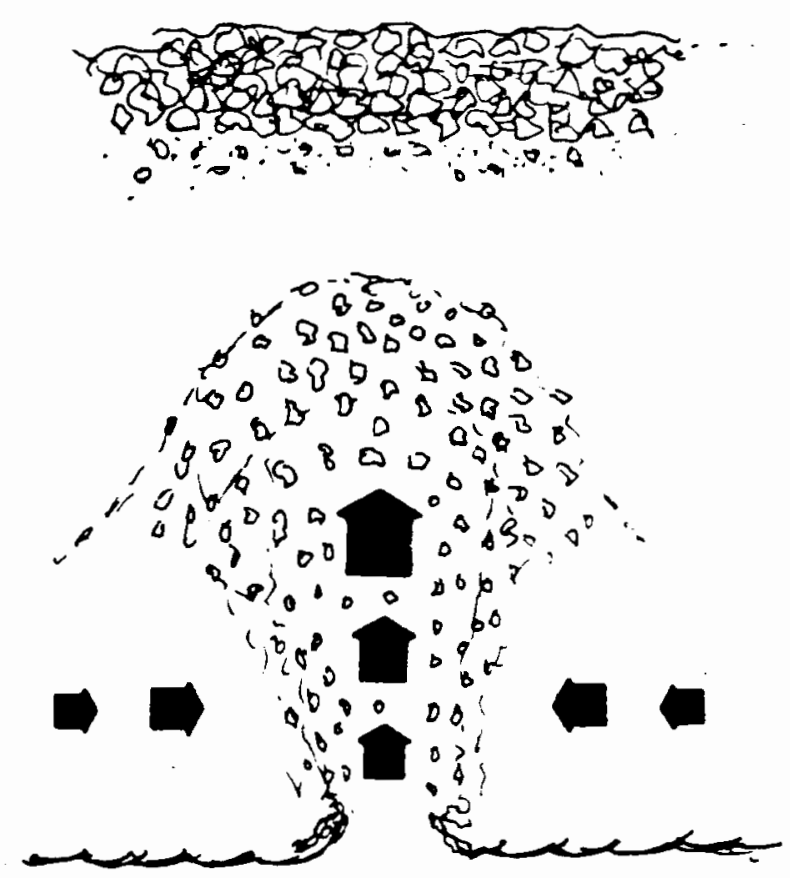

Figure 31. During the formation process, material is moved upward by the release of steam/water. Material is drawn in from the adjacent areas and moved upward. Thus depleted and enriched material can be mixed.

concentrations found in the geochemical data in brecciated flow areas. Most of the elements which significantly displayed the patterns of enrichment or depletion can be found in the plagioclase, clinopyroxene, and opaque minerals (Vlasov, 1966).

Similarly the distribution of the remaining elements could be explained by the same mixing manner. Overall, the petrographic textures, jointing patterns and geochemical trends reflect a mixing process during the formation of an explosion structure. The mechanisms that drive the process of formation must involve movement of basalt by vertical movement from immediate subjacent intraflow zones of an explosion structure and by material drawn in from the 
areas surrounding an explosion structure.

Additionally, the process of formation causes fragmentation. Basaltic arms within the lower portion of the confining walls zone of an explosion structure have ripple-like surfaces along joint traces and are fointed into plates. The plates consist of welded fragments. The ripple-like marks and the fragments imply shearing and fragmentation of the lava. After formation of the fragments, sufficient heat was still available to weld the fragments into plates. Similar fragmentation is observed where basaltic arms penetrate into the edges of the central spine. The basaltic arms are fragmented into black-colored pieces and these pieces are, in turn, incorporated into the matrix-supported breccia of the spine. Sufficient heat still remained so that the breccia was welded together. These black-colored fragments are one source of the composite-type clasts in the spine.

Distribution of the clast types reflect the process of formation of an explosion structure. The black-colored basalt, vesicular to non-vesicular composite-type clast (BVA) have greater abundance than the other types of clasts. This type of clast could have been generated from shearing and fragmentation of the confining walls or basaltic arms. The more vigorous the process of formation or the longer the explosion process lasted, the more clasts would be produced. The distribution of clast sizes indicates lapilli-sized clasts are produced in greater abundance during the formation process than block-sized clasts.

However, the size distribution is misleading, because the 
lapilli-sized clasts are generally found in greater abundance in the outer matrix-supported breccia of the central spine. Block-sized clasts increase in abundance in the inner clast-supported breccia core. This difference in size distribution would be reasonably explained by two different formation processes: 1) episodic explosions and 2) single event explosion. An episodic process consists of multiple pulses of intense activity followed by waning pulses. Different pulses produce clast types and sizes in different proportions. A single event process would distribute the strength of the explosion in time and across an explosion structure. This distribution influences size and abundance of the clast types.

The distribution of types of clasts changes slightly from the outer matrix-supported breccia to inner core of clast-supported breccia within the central spine. The abundance of scoriaceous or vesicular type of clasts increases in the core. This trend may indicate that during the formation process, the composite blackcolored clasts (BVA) are fragmented from the peripheral, but are not incorporated as easily into the clast-supported core. Clasts of the inner core of the spine may be generated along the center of the arch of the confining walls, where the vesicular clasts and pockets are observed. The vesicular clasts and pockets that are now observed represent the dying stage of the formation process. During the height of the explosion process, the center of the arch served as a point of generation for the clasts of the inner core of a central spine. The boundaries of vesicular clasts and pockets are not visible in the field in the lower portion of an explosion 
structure, but become apparent farther upward towards the central spine. If indeed this is true, then these vesicular clasts and pockets represent incipient clasts that during the height of the brecciation process form the majority of the type of clasts found in the inner core of the spine.

clast sizes and types have been analyzed for natural systems and modeled in experimental systems for hydromagmatic or hydrovolcanic explosions (Wohletz and Sheridan, 1983, Wohletz and McQueen, 1984; Wohletz, 1983, 1986; Sheridan and Wohletz, 1983). Clast sizes are dependent on the strength of the explosion. The strength of explosion is determined by the ratio of the mass of water to the mass of lava. Smaller clast sizes are indicative of stronger more violent reactions and low mass ratios. Larger-sized clasts indicate weaker intereactions and high mass ratios. An explosion structure in the Troy flow has both lapilli and block sizes. Thus the process producing an explosion structure 1) involves separate explosions of different intensities or 2 ) the force of the explosions are distributed through a volume of lava. One possible explanation for the size discrepancy could be that the process of formation is episodic. The lapilli size fragments are produced during each period of intense activity; block sizes are produced during periods of lower activity and high ratios of water to lava. An alternative process, a single event, distributes the energy across the explosion structure and through time. The distribution of energy release controls sizes and types of clasts as indicated in the traverse measurements of a central 
spine that show an inner clast-supported breccia surrounded by matrix-supported breccia.

If the process of formation were episodic, then this process would produce a horizontally stratified breccia rather than the observed vertically stratified central spine. The lapilli size fragments would be produced during the intense explostons and these fragments are forced upward (Figure 32). A less intense explosion could follow and produce block size fragments. These fragments are forced upward and add another layer to the bottom of the central spine. If more explosions follow, the central spine may appear horizontally layered.
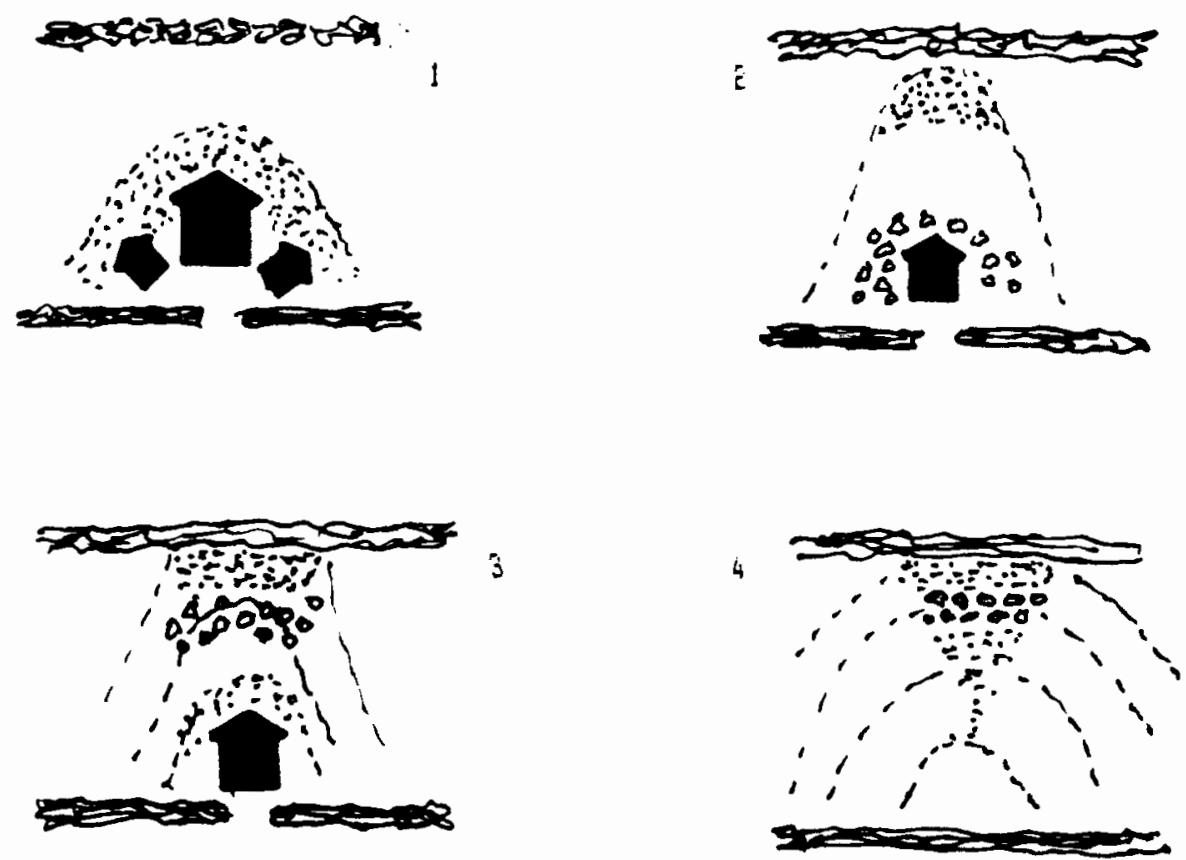

Figure 32. An episodic event process starts with an intense explosion that produces lapilli size fragments. less violent explosion follows that produces block size fragments and these fragments add another layer to the breccia of the central spine. The cycle is repeated. These explosions wane and result in a horizontally stratified central spine. 
The single event process may be more reasonable. During the initial moments, low mass ratios cause extremely intense explosions that produced lapilli-sized clasts (Figure 33). Fragmentation processes were dominant over vesiculation. Lapilli-sized clasts were forced upward and formed the outer matrix-supported breccia. Energy waned when more steam/water interacted with the molten basalt. Vesiculation became dominant. Block-sized clasts were generated and carried upward by a greater proportion of steam/water then produced the clast-supported core.
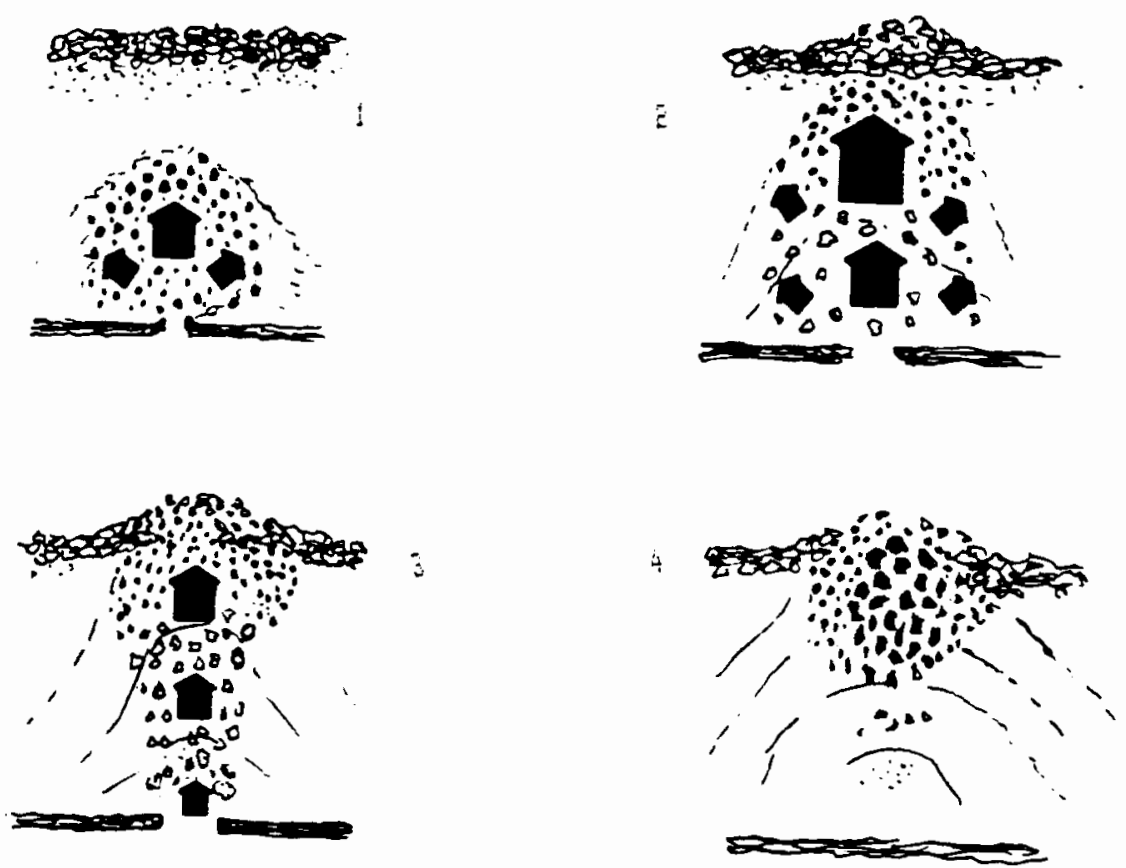

Figure 33. A single event process increases in intensity as during the initial moments ( 1 to 2). During these two steps, the finer breccia clasts are formed, because the mass ratio of water to melt is low. As more water is incorporated in the process, the mass ratio increases and the strength of the release of steam/water wanes. Larger clasts are formed during this step (3). The final stage shows the stratification within the central spine and the jointing formed. 
The formation of an explosion involves mixing of basalt from either the subjacent intraflow zones of the second cooling unit or basalt drawn from the basal portion of the flow. The mixing process occurred after initial crystallization of the Troy flow as indicated by the formation of contrasting bands or layers of different textures of basalt (vitrphyric to intergranular) within the confining walls. The aligned microphenocrysts and microlites within these bands or layers of basalt indicate movement. That movement was upward through the Troy flow is indicated by the banded nature of different textural features, the alignment of microphenocrysts and microlites found within these features, and deformation along joint traces that resulted in ripple-1ike surfaces. The location of the explosion within the flow could be 1) within the body of the flow above the lower zones of the second cooling unit or 2) at the base of the second cooling unit.

A model for the formation of explosion structures depends on 1) water being present and available to interact with the basalt, 2) physical variables such as the transfer of heat from the flow to the trapped water, and 3) a mechanism to trigger and fragment the basalt so an explosion can take place. The presence of water at the time of the eruption of the Troy flow is indicated by the red clay zone below the first cooling unit and possible influence of water in the crystallization sequences within the intraflow zones of the second cooling unit.

The timing of the emplacement of the second cooling unit in relation to the first cooling unit is unclear from field 
observations. The first cooling unit contains a greater portion of vesicles within the basal intraflow zones than the second cooling unit. The vesicles within the first unit are probably due to a high abundance of volatiles. High volatile contents within Hawailan lavas reduce viscosity and increase fluidity within the flows (Lipman and Banks, 1987). The initial volume erupting at the vents produced the thinner first cooling unit and a greater subsequent volume produced the thicker second cooling unit. The lava of the first cooling unit was highly fluid and flowed rapidly from the vents following topographical lows. The thicker second unit followed and covered the topography that included the first unit. The second unit could influence the crystallization sequence within the first cooling unit, if crystallization within the first unit was not complete within this unit. The heat from the second unit may have slowed the cooling of the first unit.

The crystallization of the first unit, if influenced by sufficient heat transferred from the second unit, should have resulted in well-developed intergranular textures. Vesicles within the still molten first cooling unit should have risen upward and concentrated within the upper portion of the first unit, thereby producing a vesicle-free interior. Vesicles, if present within the interior of the first unit, should occur randomly and be spherical in shape. However, vesicles occur within the interior of the first unit and concentrate within bands or layers parallel to the base of the first unit. Vesicles are elongated parallel to the boundaries of the bands or layers. The elongated shape of the vesicles 
indicates that movement parallel to the base of the first unit occurred as the lava crystallized. Thus, the crystallization of the first cooling unit was not influenced by the heat from the second cooling unit, because sufficient time (couple of days) may have passed before the second unit arrived.

An explosion structure is typically symmetrical, as illustrated by the symmetry of the jointing pattern forming an arch of concentric layers. Along the axis of symmetry of an explosion structure is the first cooling unit that occupies a trough in the subjacent topography (Orzol and Cummings, 1987). A red baked clay is present in the trough and the superjacent chilled pahoehoe base has quenched vitrophyric textures. Microphenocrysts of plagioclase and clinopyroxene show swallow-tailed crystal morphology similar to quenched textures found in pillow rinds of basalt described by Bryan (1972). This quenched texture implies that the red clay zone was saturated and/or surface water was present.

Since the second cooling unit also has a similar chilled pahoehoe base, water must have interacted to quench the base of this unit. A reasonable explanation could involve the first cooling unit flowing along a stream channel forcing channel water to ramp up and override the first unit. The second cooling unit followed, trapping the water between the separating cooling units. The much thicker second cooling unit would not allow ramping of water as did the much thinner first unit. The water could have been forced into the voids of the clast-supported scoriaceous top of the first cooling unit. 
the Troy. Ross (1978) found hyaloclastite beds above and below the Troy flow that suggest water interacted with flows of Grande Ronde Basalt. He suggested that the Grouse Flat syncline was active at the time of eruption of the Troy flow. The Grouse Flat syncline could have served as a basin for a body of water, or, together with the Saddle Butte anticline, acted to develop relief upon which stream drainages developed. Furthermore, colonnade jointing occurs within the Troy flow and within other flows above and before the Troy flow locally. Long (1987) has reported the development of entablatures and colonnades in Columbia River Basalt depends upon quenching of partially crystallized basalt from lakes and streams Inundating the Columbia Plateau. Thus water in streams or lakes was present at the time of the eruption the Troy flow.

Water is soluble in basaltic melts and solublity increases steadly with increasing pressures over 1,000 bars (Burnham, 1975; Hamilton and others, 1964; Khitarov and Kadik, 1973; Silver and Stolper, 1985). The mixing of water into a basaltic melt causes dramatic effects on crystallization and on such physical properties of the lava such as viscosity (Burnham, 1975; Loomis, 1979; Drake, 1976). The introduced water reacts with the silica tetrahedra resulting in an exchange of a proton from water with a cation within the tetrahedra thereby breaking the tetrahedra. Crystallization sequences and textures would change (Hamilton and others, 1964). The intraflow textures in brecciated flow areas indicate a different crystallization sequence than unbrecciated to non-brecciated flow areas. If water was forced into the base of the second cooling unit 
of the Troy flow during the explosion process, silica tetrahedra within the basalt would break apart from interaction with water molecules. Thus this interaction would hinder the formation of plagioclase and pyroxene microlites and result in a greater portion of glass forming. This basal portion could be a source for the bands or layers of vitrophyric textures within the confining walls that were transported upward and mixed during the formation process of an explosion structure.

Oxygen fugacity in a melt can be influenced by the introduction of water (Hamilton and others, 1964; Osborn, 1959). Water would increase $\mathrm{fo}_{2}$ in the melt and determine the course of the crystallization sequence. Hamilton and others (1964) reported that melts at high $\mathrm{fo}_{2}$ and temperatures, when quenched, result in high proportion of glass. At lower $\mathrm{fo}_{2}$, the quenched charges include clinopyroxene and plagioclase crystals. Thus high oxygen fugacity decreases the temperatures at which clinopyroxene and plagioclase begin to crystallize. These conditions may explain the black colored vitrophyric textures in the confining walls.

The enclosed bodies of breccia adjacent to the confining walls within an explosion structure have reddish-color. Results from Mossbauer analysis show hematite is present within these breccias, while results show magnetite is present within the adjacent blackcolored confining walls. The steam/water may have reacted during the formation process 1) to alter magnetite grains to hematite or 2) to cause hematite to crystallize directly. Thus water was available to interact during the formation of an explosion structure within 
the Troy flow.

Transfer of heat can be accomplished from the molten Troy flow to the water trapped between the first and second cooling units. Features in the bases of basaltic flows in Columbia River basalt resulting from interaction with water or gas have been reported by many authors: Fuller (1931), Waters (1960), Schminke (1967), and Swanson (1967). Features ranging from pillowed bases to peperites are generated from the contact of molten lava and water or watersaturated sediments or burnt vegetation. Phreatic-explosion pits near Mount St. Helens, Washington were generated when hot pyroclastic flows and debris flows covered water in streams, ponds, and springs (Rowley and others, 1981). The water flashed to steam and formed explosion pits. Minor steam explosions occurred where the 1801 Huehue lava flow, Hawail, overran water-soaked ground (Moore, 1970). Similar explosion spatter rings and craters are observed in Iceland after water either entered or was trapped below a lava flow and exploded (Walker, 1971).

Lava flows entering the sea off the Hawaiian Islands can transfer sufficient energy to elevate seawater temperatures or have caused explosions that form littoral cones (Wentworth and others, 1953; MacDonald, 1949; Moore and others, 1973; Fisher and Schminke, 1984). The type of lava flow, aa or pahoehoe, influence the dynamics, because pahoehoe flows often form pillowed lavas and aa flows form littoral cones. A pahoehoe flow forms an insulating crust inhibiting the transfer of heat from the interior to the surroundings, while an aa flow has open fractures conducive to 
transfer of heat by air or water.

Pahoehoe flows in Hawailan Islands can form pillows, but not all flows do so (Moore and others, 1973). Some flows maintain coherence and extend along the sea bottom as lava tongues. If slopes are gentle, flows into the sea will not produce pillows; where slopes are steep, pillows to breccias will form (Moore and others, 1971). Slopes in the study area at the time of the eruption of the Troy flow were gentle. This is suggested by the maximum dips of the Grouse Flat syncline of only a maximum $3^{\circ}$ (Ross, 1978). Neither the first nor the second cooling units of the Troy flow formed pillows.

The temperature of the Troy flow was probably maintained by rapid flowage and by processes similar to those acting during the flow of a Hawaiian lava. The temperatures of Hawaiian lavas are sustained by the heat of crystallization (Lipman and Banks, 1987) and by the heat derived from frictional deformation of the melt (Shaw, 1969). Shaw and Swanson (1970) calculated heat loss during flow was mainly by radiation and a typical flow cooled an average of $50^{\circ} \mathrm{C}$ over a distance of $200 \mathrm{~km}$ in approximately 10 hours. Cooling rates for a lava lake in Hawaii with a maximum depth of less than 30 meters took nearly four years from the initial temperature of $1190^{\circ}$ $\mathrm{C}$ to reach temperatures below $1000^{\circ} \mathrm{C}$ at the base of the lava lake (Wright and Okamura, 1977). An estimate for the Troy flow, which is more than three times thicker, would be about 12 to 15 years.

Estimates for the temperatures of erupting Hawaiian basalt range from $1225^{\circ} \mathrm{C}$ to $1050^{\circ} \mathrm{C}$ (Peck and others, 1964; 1966; Shaw and 
others, 1968; Wright and others, 1977; MacDonald, 1963; and Shaw and others, 1977). Thermoconductivities are initially high for the cooling of a Columbia River Basalt sample at $1200^{\circ} \mathrm{C}$, then are slightly influenced by the presence of crytals (Murase and McBirney, 1973). Thermoconductivities begin to climb again after cooling to approximately $1000^{\circ} \mathrm{C}$.

Transfer of the heat occurs downward across the basal contact of the second cooling unit and possibly sufficient heat will turn the water trapped between the cooling units to steam. The pressure from the weight of the second cooling unit would act on the water trapped in the voids of the clast-supported breccia of the first cooling unit. Once the steam pressure reached a critical value, the basal contact would crack; the pressure release would cause remaining water to turn to steam and explode upward through the crack.

An alternate mechanism for fracturing the basal crust could be the result of tectonic activity. Trends of the central spines of explosion structures have either an orientation similar to the northeasterly trending Grande Ronde fault system or the northwesterly trending dike system in the study area. A northwesttrending fault, the Squaw Canyon fault, is also part of the fault system. Movement along these faults after the eruption of the Troy flow could fracture the base of the second cooling unit at various locations. These favorable locations could coincide with presence of the first cooling unit and subjacent troughs occupied by the first unit. Another explanation for the orientations of the central 
spines is that the faulting of the Grande Ronde and folding of both Grouse Flat syncline and Saddle Butte anticline could have controlled the topography in the study area. Drainages developed on the topography could have developed orientations in northeast and northwest directions.

Another alternative to heating the water to produce sufficient pressure to crack the basal crust involved fuel-coolant reactions. Fuel-coolant reactions have been studied as analogs to natural systems producing hydroexplosions. A chain of processes has been advanced as a pathway model for a thermal explosion resulting from contact of molten material and coolant (Figure 34) (Buchanan, 1974; Board and others, 1974). The chain of processes has a feedback

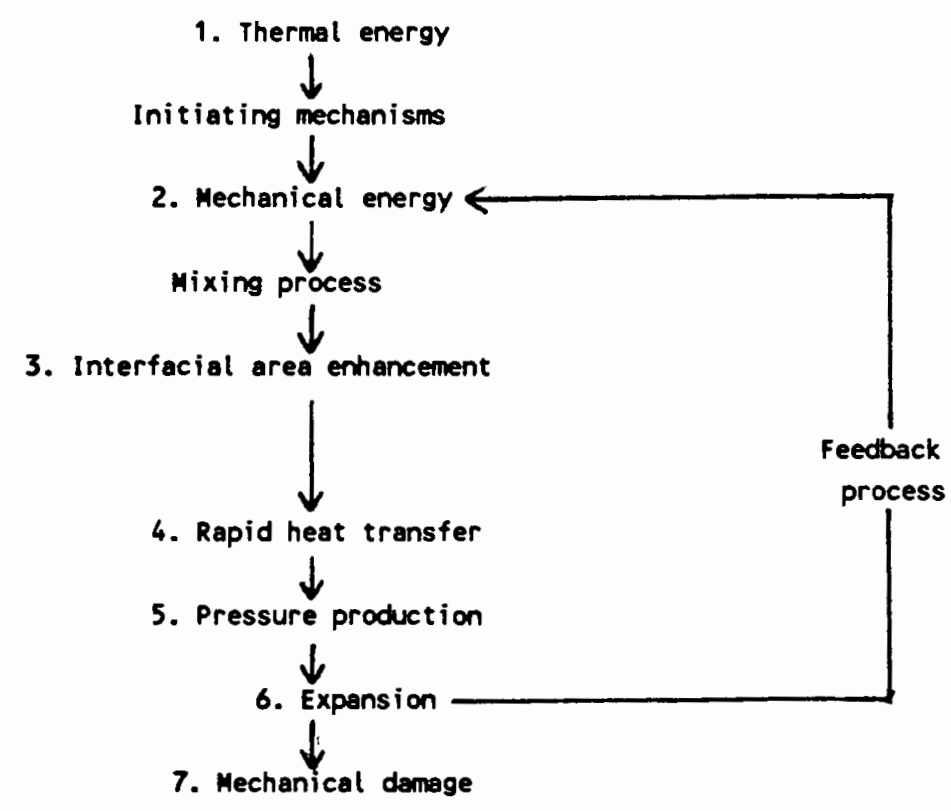

Figure 34. A schematic summarizing the logical sequence of explosion processes involved in fuel-coolant reactions. (after Board and others, 1974). 
mechanism. The initiating mechanisms are not well understood, but a variety of proposed mechanisms exist. Witte and others (1970) proposed four triggering mechanisms: entrapment, violent boiling, shell theory, and Weber number effect. All four mechanisms produce fragmentation and thereby transfer the heat needed for an explosion, but do not fully explain recent experimental or field findings (Board and others, 1971; Wohletz, 1983; Wohletz and Sheridan, 1983; Wohletz and McQueen, 1984; Sheridan and Wohletz, 1983).

Kokelaar (1986) proposed four mechanisms: 1) magmatic explosivity caused by the explosive release of magmatic volatiles, 2) contact-surface steam explosivity from the explosive expansion and collapse of steam formed at magma-water contact surfaces, 3) bulk interaction steam explosivity produced by explosive expansion following enclosure of water in magma, or entrapment of water close to magma, and 4) cooling-contraction granulation from cooling and contraction of molten material. In the case of the Troy flow, the latter three mechanisms appear applicable.

Wohletz (1986) describes two models requiring film boiling prior to explosion (mechanism 2 from Kokelaar): the superheating model and the thermal detonation model. Film boiling permit the two processes to operate simultaneously: partial thermal insulation of the molten material from the water and gradual fragmention and mixing of the molten material by the instabilities from film boiling. The transfer of heat is accomplished by the increased area from mixing, thereby causing rapid vaporization followed by an explosion. This scenario will only happen if the water is 
superheated to temperatures at or above the spontaneous vapor nucleation temperature of water and secondly if a pressure wave (thermal detonation) causes finer fragmentation and subsequent collapse of an insulating film surrounding the fragments. This cycle is repeated until an explosion is generated.

Superheating of a liquid involves raising the temperature of this liquid above the normal boiling point for any given pressure while still remaining a liquid. Wohletz (1986) reported the requirement of superheating is not easily met by the initial conditions of basalt-water contact. Several types of instabilities may cause oscillation of the layer of film boiling. These instabilities cause the surface of the magma or lava to distort into waves. The chilled pahoehoe base has unusual surface digitations which may be a result of oscillations that failed during the waning stages of formation. A thermal detonation causes differential acceleration of the melt particles relative to the water. Thermal detonation may not be likely, but volcanic systems satisfy detonation requirements (Wohletz, 1986).

Several triggering mechanisms of formation have been advanced that would result in formation of an explosion structure. Triggering mechanisms are 1) tectonic in origin from faulting or folding, 2) sufficient pressure to fracture the base, and 3) fuelcoolant type interactions. Triggering mechanisms must fracture and fragment the base and basal portion of the second cooling unit and transfer sufficient heat for steam/water to explode upward into the flow. After the explosion is triggered, the process may develop 
episodically or as a single event. As steam/water exploded upward through the flow, superheating of the steam/water could operate during the transition towards the top.

Reid (1976) successfully demonstrated a model using a column of heated liquid. The column of liquid was heated greater at the top than the bottom; thus, convection did not operate within the column. Next, he injected a drop of lower density liquid from the bottom of the column. The drop formed a rising bubble that superheated and exploded. The situation involving the Troy flow is similar in that the steam/water will move upward through the flow towards the hotter molten interior. This superheating could cause further expansion of steam/water and possibly additional fragmentation. This additional fragmentation may have resulted in finer clast sizes such as the extremely small sizes observed in thin section of the textural bands in samples from trapped bodies of breccia. The finely brecciated rind on some breccia clasts from the central spine may have been produced by the additional fragmentation from superheating.

Upward movement of steam/water caused 1) fragments to be incorporated into a breccia of the central spine, 2) development of the intraflow zones and their petrographic textures from mixing of the basalt, and 3 ) the overall shape of an explosion feature in an arch delinearated by the joint pattern. 


\section{CHAPTER V}

\section{CONCLUSION}

1) Explosion structures in the study area are restricted to Grande Ronde Basalt and are absent in Wanapum and Saddle Mountains Basalts. The distribution within Grande Ronde Basalts is not controlled by the Grande Ronde fault system, because brecciated flows are observed on both sides of the faults of the system. The regional structural features, the Grande Ronde fault system, Grouse Flat syncline, and the Saddle Butte anticline, probably controlled the pre-eruption topography and thereby influenced the orientations of the central spines within brecciated flows. Brecciated flows are composed of two cooling units. The first unit occupying troughs in the pre-eruption topography and the second unit containing the explosion structure. The maximum number of brecciated flows at any one stratigraphic site is six flows. Only one stratigraphic site, Grouse Creek, lacked brecciated flows, the remaining sites contained commonly at least two brecciated flows. Typically, the Troy flow was one of these brecciated flows. The Troy flow is usually the thickest flow measured and explosion structures are better developed within this flow. The collection of measurements from explosion structures indicates a definite relationship between the total thickness of the flow and the vertical breccia interval. 
availablity of water and b) a mechanism(s) to trigger interaction of this water with the molten basalt. Water was avallable at favorable locations in troughs of the pre-eruption topography. These favored locations are reflected in the parallel trends of the central spine of the explosion structures. Sufficient water existed in the troughs that both bases of the first and second cooling units were quenched. Water was trapped between units in the scoriaceous top of the first cooling unit.

3) Models for mechanisms triggering the violent interaction of water with molten basalt are: a) tectonic in origin, b) excessive pressure mechanism from heating, and c) fuel-coolant reactions. Tectonic mechanisms include either fracture of the base of the second unit directly from movement caused by faulting and folding or favorable troughs cut by drainage networks into pre-eruption topography that are controlled by faulting and folding. A pressure mechanism fractures the base of the second cooling unit from excessive water/steam pressure that resulted from the transfer of heat from the flow. Finally, a fuel-coolant mechanism triggered an explosion from instabilities and fragmentation along the waterbasalt interface.

4) The violent explosions can act either episodically or as a single event. Episodic formation is less reasonable, because pulses would not produce the vertical stratification in the central spine. Single event formation is more reasonable and can produce the vertical stratification. Violent upward release of steam/water causes mixing and fragmentation during formation of explosion 
structures. These two processes produced the unique intraflow zones that are reflected in the petrographic textures, geochemical characteristics and jointing patterns observed within explosion structures. 


\section{REFERENCES CITED}

Anderson, A. T., 1973, The before-eruption water content of some high-alumina magmas: Bulletin of Volcanology, v. 37, pp. 530552 .

Anderson, A. T., Friedman, J. O., Wood, T. V., and Wyszynski, J., 1982, The fractional crystallization of plagioclase in the Hat Creek Basalt: observations and theory: Journal of Geology, $v$. 90 , pp. $545-558$.

Board, S. J., Clarke, A. J., Duffey, R. B., Hall, R. S., and Poole, D. H., 1971, An experimental study of energy transfer processes relevant to thermal explosions: International Journal of Heat and Mass Transfer, v. 14, pp. 1631-1641.

Board, S. J., Hall, R. W., and Ha11, R. S., 1975, Detonation of fue1 coolant explosions: Nature, v.254, pp. 319-321.

Board, S. J., Farmer, C. L., and Poole, D. H., 1974, Fragmentation in thermal explosions: International Journal of Heat and Mass Transfer, v. 17, pp. 331-339.

Bryan, W. B., 1972, Morphology of quenched crystals in submarine basalts: Journal of Geophysical Research, v. 77, pp. 5812-5819.

Buchanan, D. J., 1974, A model for fuel-coolant interactions: Journal of Physics, Applied Physics, v. 7, pp. 1441-1457.

Buchanan, D. J., and Dullforce, T. A., 1973, Mechanisms for vapor explosions: Nature, v. 245, pp. 32-34.

Burnham, C. W., 1975, Water and magmas: a mixing model: Geochimica et Cosmochimica Acta, v. 39, pp. 1077-1084.

Cox, K. G., Bell, J. D., and Pankhurst, R. J., 1984, The interpretation of igneous rocks: London, George Allen and Unwin, $450 \mathrm{p}$.

Cummings, M. L., Orzo1, L. L., and Trone, P. M., 1987, Characteristic of the Troy flow, Grande Ronde Basalt in the area of thickened flow-top breccias, northeastern Oregon: evidence for mixing [abs.]: Geological Society of America Bulletin, Abstrasts with Programs, v. 19, pp. 369. 
Degraff, J .M., and Aydin, A., 1987, Fracture growth directions and inferred thermal regime during solidification of basaltic lava flows [abs.]: Geological Society of America Bulletin, Abstrasts with Programs, v. 19, pp. 371.

Desai, P. J. and Anderson, A. T., 1974, Nature and Origin of microphenocrysts in a basalt: Bulletin of Volcanclogy, v. 38 , pp. 65-72.

Dowty, E., Keil, K., and Prinz, M., 1974, Lunar pyroxene-phyric basalts: crystallization under supercooled conditions: Journal of Petrology, v. 15, pp. 419-453.

Drake, M. J.,1976, Plagioclase-melt equilibria: Geochimica et Cosmochimica Acta, v. 40, pp. 457-465.

Fisher, R. V., and Schmincke, H. U., 1984, Pyroclastic rocks: Berlin, Germany, Springer-Verlag, 472 p.

Fuller, R. F., 1931, The aqueous chilling of basaltic lava on the Columbia River Plateau: American Journal of Science, v. 21, pp. $281-300$.

Gibb, F. G., 1974, Supercooling and the crystallization of plagioclase from a basaltic magma: Mineralogical Magazine, v. 39, pp. 641-653.

Hamilton, D. L., Burnham, C. W., and Osborn, E. F., 1964, The solubility of water and effects of oxygen fugacity and water content on crystallization in mafic magmas: Journal of Petrology, v. 5, pp. 21-39.

Hoffer, J. M., 1966, Compositional variations of plagioclase feldspar from a basaltic lava flow: The American Mineralogist, v. 51, pp. 807-813.

Hoffer, J. M., 1970, Plagioclase mineralogy of the Rock Creek flow, Columbia River Basalt: in, Gilmour, E.H., and Stradling, D., eds., Proceedings of the second Columbia River Basalt symposium, Cheney, Washington, EWSC Press, pp. 51-54.

Holmgren, D .A., 1968, Origin of subhorizontal platey jointing in the Yakima basalt: Northwest Science, v. 42, p. 35.

Hooper, P.R., and Camp, V. E., 1981, Deformation of the southeast part of the Columbia Plateau: Geology, v. 9, pp. 323-328.

Khitarov, N. I. and Kadik, A. A., 1973, Water and carbon dioxide in magmatic melts and peculiarities of the melting process: Contribution to Mineralogy and Petrology, v. 41, pp. 205-215. 
Kirkpatrick, J. R., 1977, Nucleation and growth of plagioclase, Makaopuhi and Alae lava lakes, Kilauea Volcanco, Hawaii: Geological Society of America Bulletin, v. 88, pp. 78-84.

Kokelaar, P., 1986, Magma-water interactions in subaqueous and emergent basaltic volcanism: Bulletin of volcanology, v. 48, pp. 275-289.

Kouchi, A., Tsuchiyama, A., and Sunagawa, I., 1986, Effect of stirring on crystallization kinetics of basalt: texture and element partitioning: Contribution to Mineralogy and Petrology, v. 93, pp. 429-438.

Lipman, P. W., and Banks, N. G., 1987, AA flow dynamics, Mauna Loa 1984: in Decker, R. W., Wright, T. L., and Stauffer, P. H., eds., United States Geological Survey Professional Paper 1350, pp. $1527-1568$.

Lofgren, G. E., 1983, Effect of heterogeneous nucleation on basaltic textures: a dynamic crystallization study: Journal of Petrology, v. 24, pp. 229-255.

Long, P. E., 1987, Review of evidence for quenching origin of entablatures in Columbia River Basalt flows [abs.]: Geological Society of America Bulletin, Abstrasts with Programs, v. 19, pp. 399.

Loomis, T. P., 1979, An empirical model for plagioclase equilibrium in hydrous melts: Geochimica et Cosmochimica Acta, v. 43, pp. 1753-1759.

MacDonald, G. A., 1949, Petrography of the Island of Hawaii: United States Geological Survey Professional Paper 214-D, 95 p.

MacDonald, G. A., 1953, Pahoehoe, aa, and block lava: American Journal of Science, v. 251, pp. 169-191.

MacDonald, G. A., 1963, Physical properties of erupting Hawailan magmas: Geological Society of America Bulletin, v. 74., pp. 1071-1078.

MacDonald, G. A., 1972, Volcanoes: New Jersey, Prentice-Hall, Inc., $510 \mathrm{p}$.

Moore, J. G., 1970, Pillow lava in a historic lava flow from Hualallai Volcano, Hawail: Journal of Geology, v. 78, pp. 239243.

Moore, J. G., Cristofolini, R., and Lo Giudice, A., 1971, Development of pillows on the submarine extension of recent lava flows, Mount Etna, Sicily: United States Geological Survey Professional Paper 750-C, Pp. 89-97. 
Moore, J. G., Phillips, R. L., Grigg, R. W., Peterson, D. W., and Swanson, D. A., 1973, Flow of lava into the sea: Geological Society of America Bulletin, v. 84, pp. 537-546.

Murase, T., and McBirney, A. R., 1973, Properties of some common igneous rocks and their melts at high temperatures: Geological Society of America Bulletin, v. 84, pp. 3563-3592.

Myers, C. W. and Price, S. M., 1979, Geologic studies of the Columbia Plateau: a status report: Rockwell Hanford Operations, Richland, Washington, RHO-BWI-ST-4, 454 p.

Orzol, L. L., and Cummings, M. L., 1986, Phreatic structures in flows of the Grande Ronde Basalt, Columbia River Basalt Group, near Troy, Oregon [abs.]: Abstrasts with Programs, Geological Society of America, v. 18, pp. 167-168.

Orzol, L. L., and Cummings, M. L., 1986, Phreatic explosion features in Grande Ronde Basalt near Troy, Oregon [abs.]: Oregon Academy of Science, In Press

Orzol, L. L., and Cummings, M. L., 1987, Distribution of phreatic eruption structures in the Troy flow, Grande Ronde basalt, near Troy, Oregon [abs.]: Oregon Academy of Science, In Press

Osborn, E. F., 1959, Role of oxygen pressure in the crystallization and differentiation of basaltic magmas: American Journal of Science, v. 257, pp. 609-647.

Peck, D. L., Moore, J. G., and Kojima, G., 1964, Temperatures in the crust and melt of Alae Lava Lake, Hawaii, after the August 1963 eruption of Kilauea Volcano-a preliminary report: United States Geological Survey Professional Paper 501-D, Pp. 1-7.

Peck, D. L., Wright, T. L., and Moore. J. G., 1966, Crystallization of tholeific basalt in Alae Lava Lake, Hawaii: Bulletin of Volcanology, v. 29, pp. 629-656.

Peck, D. L., Hamilton, M. S., and Shaw, H. R., 1977, Numerical analysis lava lake cooling models: part II, application to Alae Lava Lake, Hawa11: American Journal of Science, v. 277, pp. 415-437.

Reid, R. C., 1976, Superheated liquids: American Scientist: v. 64, pp. $146-156$.

Reidel, S. P., Tolan, T. L., Anderson, J. L., Beeson, M. H., and Fecht, K. R., 1987, Regional stratigraphy of the Grande Ronde Basalt (GRB) and its tectonic and petrogenetic implications [abs.]: Geological Society of America Bulletin, Abstrasts with Programs, v. 19 , pp. 442. 
Rowley, P. D., Kuntz, M. A., and MacLeod, N. S., 1981, Pyroclasticflow deposits, in, Lipman, P. W., and Mullineaux, D. R., eds., The 1980 eruptions of Mount St. Helens, Washington, United States Geological Survey Professional Paper 1250, pp. 489-512.

Ross, M. E., 1975, The structure of Yakima basalts in a portion of the Grande Ronde River region of northeastern Oregon and southeastern Washington: Geological Society of America Abstrasts with Programs, v. 3, pp. 51.

Ross, M. E., 1978, Stratigraphy, structure, and petrology of Columbia River Basalt in a portion of the Grande Ronde RiverBlue Mountains area of Oregon and Washington: Richland, Washington, Rockwell Hanford Operations, RHO-SA-58, 460 p.

Ross, M. E., 1980, Tectonic controls of topographic development within Columbla River basalts in a portion of the Grande Ronde River-Blue Mountains region, Oregon and Washington: Oregon Geology, v. 42, pp. 167-174.

Russel, I.C., 1897, A reconnaissance in southeastern Washington: United States Geological Survey Water Supply Paper, pp. 1-76.

Schmincke, H. U., 1967, Stratigraphy and petrography of four upper Yakima basalt flows in south-central Washington: Geological Society of American Bulletin, v. 78, pp. 1385-1422.

Shaw, H. R., Wright, T. L., Peck, D. L., and Okamura, R., 1968, The viscosity of basaltic magma: an analysis of field measurements in Makaopuhi Lava Lake, Hawail: American Journal of Science, v. 266, pp. 225-264.

Shaw, H. R., 1969, Rheology of basalt in the melting range: Journal of Petrology, v. 10, pp. 510-535.

Shaw, H. R., 1972, Viscosities of magmatic silicate liquids: an empirical method of prediction: American Journal of Science, v. 272, PP. 870-893.

Shaw, H. R., and Swanson, D. A., 1970, Eruption and flow rates of flood basalts: In, Gilmour, E.H., and Stradling, D., eds., Proceedings of the second Columbia River Basalt Symposium, Cheney, Washington, EWSC Press, pp. 271-300.

Shaw, H. R., Hamilton, M. S., and Peck, D. L., 1977, Numerical analysis of lava lake cooling models: part I, Description of the method: American Journal of Science, v. 277, p. 384-414.

Sheridan, M. F., and Wohletz, K. H., 1983, Hydrovolcanism: Basic considerations and review: Journal of Volcanology and Geothermal Research, v. 17, pp. 1-29. 
Silver, L., and Stolper, E., 1985, A thermodynamic model for hydrous silicate melts: Journal of Geology, v. 93, pp. 161-178.

Smith, R. L., 1960, Ash flows: Geological Society of American Bulletin, v. 71, pp. 795-842.

Stoffel, K. L., 1981, Preliminary report on the geology of the Grande Ronde lignite field, Asotin County, Washington: State of Washington, Division of Geology and Earth Resources, OpenFile Report 81-6, $30 \mathrm{p}$.

Stoffe1, K. L., 1984, Geology of the Grande Ronde lignite field Asotin County, Washington: State of Washington, Division of Geology and Earth Resources, Report of Investigations 27, 79 p.

Swanson, D. A., 1967, Yakima basalt of the Tieton River area, southcentral Washington: Geological Society of America Bulletin, v. 78, pp. $1077-1110$.

Swanson, D. A., and Wright, T. L., and Helz, R. T., 1975, Linear vent systems and estimated rates of magma production and eruption for the Yakima Basalt on the Columbia Plateau: American Journal of Science, v. 275, pp. 877-905.

Swanson, D. A., and Wright, T. L., Hooper, P. R., and Bently, R. D., 1979, Revisions in stratigraphic nomenclature of the Columbia River Basalt Group: United States Geological Survey Bulletin $1457-\mathrm{C}, 59 \mathrm{p}$.

Swanson, D. A., and Wright, T. L., Camp, V. E., Gardner, J. N., Helz, R. T., Price, S. A., and Ross, M. E., 1977, Reconnaissance geologic map of the Columbia River Basalt Group, Pullman and Walla Walla quadrangles, southeast Washington and adjacent Idaho: United States Geological Survey Open File Map, 77-100.

Swanson, D. A., and Wright, T. L., 1981, Guide to geologic field trip between Lewiston, Idaho, and Kimberly, Oregon, emphasizing the Columbia River Basalt Group, in, Johnston, D. A. and Nolan-Donnelly, eds., Guides to some volcanic terranes in Washington, Idaho, Oregon, and Northern California: United States Geological Survey Circular 838, pp. 1-15.

Tolan, T. L., Reidel, S. P., Beeson, M. H., Anderson, J. L., Fecht, K. R., and Swanson, D. A., 1987, Revisions to the areal extent and volume of the Columbia River Basalt Group (CRBG) [abs.]: Geological Society of America Bulletin, Abstrasts with Programs, v. 19 , pp. 458 
Walker, D., Kirkpatrick, R. J., Longhi, J., and Hays, J. F., 1976, Crystallization history of lunar picritic basalt sample 12002: phase-equilibrium and cooling rates studies: Geological Society of America Bulletin, v. 87, Pp. 646-656.

Walker, G. P., 1971, Characteristics of some basaltic pyoclastics: Bulletin of Volcanology, v. 35, pp. 305-317.

Walker, G. W., 1973, Contrasting compositions of the youngest Columbia River basalt flows in Union and Wallowa Counties, northeastern Oregon: Geological Society of American Bulletin, v. 84 , Pp. $425-430$.

Walker, G. W., 1979, Reconnaissance geologic map of the Oregon part of the Grangeville quadrangle, Baker, Union, Umatilla, and Wallowa Counties, Oregon: United States Geological Survey Miscellaneous Investigations Series, Map I-1116, scale $1: 250,000$.

Waters, A. C., 1955, Volcanic rocks and the tectonic cycle: Geological Society of American, Special Paper 62, pp. 703-722.

Waters, A. C., 1960, Determining direction of flow in basalts: American Journal of Science, v. 258-A, PP. 350-366.

Waters, A. C., 1961, Stratigraphic and 1ithologic variations in the Columbia River basalt: American Journal of Science, v. 259, pp. 583-611.

Wentworth, C. K., and MacDonald, G. A., 1953, Structures and forms of basaltic rocks in Hawaii: United States Geological Survey Bulletin $994,98 \mathrm{p}$.

Williams, H., Turner, F. J., and Gilbert, C. M., 1982, Petrography: an introduction to the study of rocks in thin sections: San Francisco, W.H. Freeman and Company, 626 p.

Witte, L. C., Cox, J. E., and Bouvier, 1970, The vapor explosion: Journal of Metals, v. 22, Pp. 39-44.

Wohletz, K. H., 1983, Mechanisms of hydrovolcanic pyroclast formation: grain-size, scanning electron microscopy, and experimental studies: Journal of Volcanology and Geothermal Research, v. 17, pp. 31-63.

Wohletz, K. H., and Sheridan, M. F., 1983, Hydrovolcanic explosions II. Evolution of basaltic tuff rings and tuff cones: American Journal of Science, v. 283, pp. 385-413. 
Wohletz, K. H., and McQueen, R. G., 1984b, Experimental studies of hydromagmatic volcanism: in, Explosive volcanism: Inception, evolution, and hazards, Studies in geophysics: National Academy Press, Washington, DC, Pp. 158-169.

Wohletz, K. H., 1986, Explosive magma-water interactions: thermodynamics, explosion mechanisms, and field studies: Bulletin of Volcanology, v. 48, pp. 245-264.

Wright, T. L, and Okamura, R. T., 1977, Cooling and crystallization of tholeiitic basalt, 1965 Makaopuhi Lava Lake, Hawail: United States Geological Survey Professional Paper 1004, $78 \mathrm{p}$.

Vlasov, K. A., 1966, Geochemistry of rare elements Volume I: ed., Jerusalem, Israel, S. Monson, 688 p. 
APPENDIX A

SUMMARY OF STRATIGRAPHIC AND SAMPLE INFORMATION 
TABLE XIII

SUMMARY OF LOCATIONS, MAP SYMBOL, FLOU TYPES FOR EACH STRATIGRAPHIC SECTION

\begin{tabular}{|c|c|c|c|c|c|c|}
\hline $\begin{array}{l}\text { Stratigraphic } \\
\text { site label }\end{array}$ & $\begin{array}{l}\text { *Map } \\
\text { symbol }\end{array}$ & $\begin{array}{l}\text { +Type } \\
\text { section }\end{array}$ & $\begin{array}{l}\text { STotal } \\
\text { Flows }\end{array}$ & $\begin{array}{l}\text { \&Troy } \\
\text { Brecciated }\end{array}$ & $\begin{array}{r}\text { Starting } \\
71 / 2 \text { minute }\end{array}$ & $\begin{array}{l}\text { g Location } \\
\text { e quadrangles }\end{array}$ \\
\hline Eden Bench & EB & ve & 6 & $Y$ & $\mathrm{NE} 1 / 4, \mathrm{NH} 1 / 4, \mathrm{SE} 1 / 4$ & Sect 5 T5N R43E Troy \\
\hline Wenaha Camp & WC & v & 1 & $Y$ & $\mathrm{SE} 1 / 4, \mathrm{NE} 1 / 4, \mathrm{NH} 1 / 4$ & Sect 5 TSN R43E Troy \\
\hline Wenaha Camp Road & WCR & v & 3 & $Y$ & SE1/4, NE 1/4, NH1/4 & Sect 5 TSN R43E Troy \\
\hline Umat illa & $\mathrm{U}$ & vc & 4 & $\mathbf{Y}$ & $\mathrm{SE} 1 / 4, \mathrm{NE} 1 / 4, \mathrm{NE} 1 / 4$ & Sect 1 T6N R42E Eden \\
\hline Crooked Creek & $\mathrm{cc}$ & vc & 2 & $\mathbf{Y}$ & SH1/4, SW1/4, NE $1 / 4$ & Sect 27 T6N R42E Eden \\
\hline South Wenaha & SH & v & 2 & $Y$ & $\mathrm{SW} 1 / 4, \mathrm{NE} 1 / 4, \mathrm{NE} 1 / 4$ & Sect 5 T5N R43E Troy \\
\hline Wenaha Ravine & WR & v & 1 & 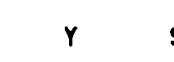 & SE1 $/ 4, N H 1 / 4, N E 1 / 4$ & Sect 5 T5N R43E Troy \\
\hline Elloit Bend & EF & B & $\geq 3$ & $\mathbf{Y}$ & $\mathrm{NH} 1 / 4, \mathrm{NH} 1 / 4, \mathrm{SE} 1 / 4$ & Sect 9 T5N R43E Troy \\
\hline Grouse Creek & GC & vc & 0 & 0 & $\mathrm{NE} 1 / 4, \mathrm{SH} 1 / 4, \mathrm{SH} 1 / 4$ & Sect 24 T5N R43E Troy \\
\hline Hoodoo Trail & $H$ & vc & 3 & $\mathbf{Y}$ & $\mathrm{SE} 1 / 4, \mathrm{NE} 1 / 4, \mathrm{SH} 1 / 4$ & Sect 29 T6N R42E Eden \\
\hline Maggie Canyon & MC & B & $\geq 2$ & $Y$ & NH1/4, SE $1 / 4$, NH1/4 & Sect 3 T5N R43E Troy \\
\hline Lighte Flat & LF & B & $\geq 2$ & $r$ & NH1 $/ 4$, SW1 $/ 4, N H 1 / 4$ & Sect 3 T5N R43E Troy \\
\hline Squaw Canyon \#1 & sc1 & B & $\geq 4$ & $\mathbf{Y}$ & NH1/4, SE1/4, NH1/4 & Sect 35 T6N R43E Troy \\
\hline Squaw Canyon \#2 & $\mathrm{sc} 2$ & $\mathbf{B}$ & $\geq 2$ & $\mathbf{Y}$ & NE1/4, SH1/4, NE $1 / 4$ & Sect 35 T6N R43E TroY \\
\hline Floral Grade & $\mathbf{F}$ & $\mathbf{v}$ & $\geq 2$ & $c$ & SE $1 / 4, \mathrm{SH} 1 / 4, \mathrm{NH} 1 / 4$ & Sect 1 T5N R43E Troy \\
\hline South Grande Ronde & SG & $\mathbf{B}$ & 3 & $\mathbf{Y}$ & $\mathrm{NH} 1 / 4, \mathrm{SH} 1 / 4, \mathrm{NH} 1 / 4$ & Sect 17 T5N R43E Troy \\
\hline Saddle Mountain & SM & B & $\geq 2$ & $\mathbf{Y}$ & $\begin{array}{l}\text { SE1/4, SH1/4,NE1/4 } \\
\text { Saddle Butte }\end{array}$ & Sect 29 T7N R43E \\
\hline Wenaha River & $H$ & v & $\geq 1$ & $\mathbf{Y}$ & SH1/4, SH1/4, NH1/4 & Sect 5 T5N R43E Troy \\
\hline Cougar Creek & c & $\mathbf{v}$ & $\geq 1$ & $Y$ & $\begin{array}{r}\mathrm{NE} 1 / 4, \mathrm{NE} 1 / 4, \mathrm{NH} 1 / 4 \\
\text { Mountain View }\end{array}$ & Sect 32 TTN R44E \\
\hline
\end{tabular}

* Map Symbols are used to indentify the stratigraphic sections on Plate 1 and used to indentify each section in Appendix $A$.

+ Type section indicates the method used to measure each stratigraphic section. VC - vertical complete section through all flows present at the site.

$V$ - partial vertical section through selected flows.

B - lateral section to dtermine horizontal variations through one or more flows.

$\$$ The total number of brecciated flows present.

\& Troy Brecciated indicates if the Troy flow contained explosion structures ( $Y$ ) or lacks explosion structures $(0)$ or the Troy flow was covered $(C)$. 
Table XIV

DEFINITIONS FOR SYMBOLS USED IN STRATIGRAPHIC SECTIONS

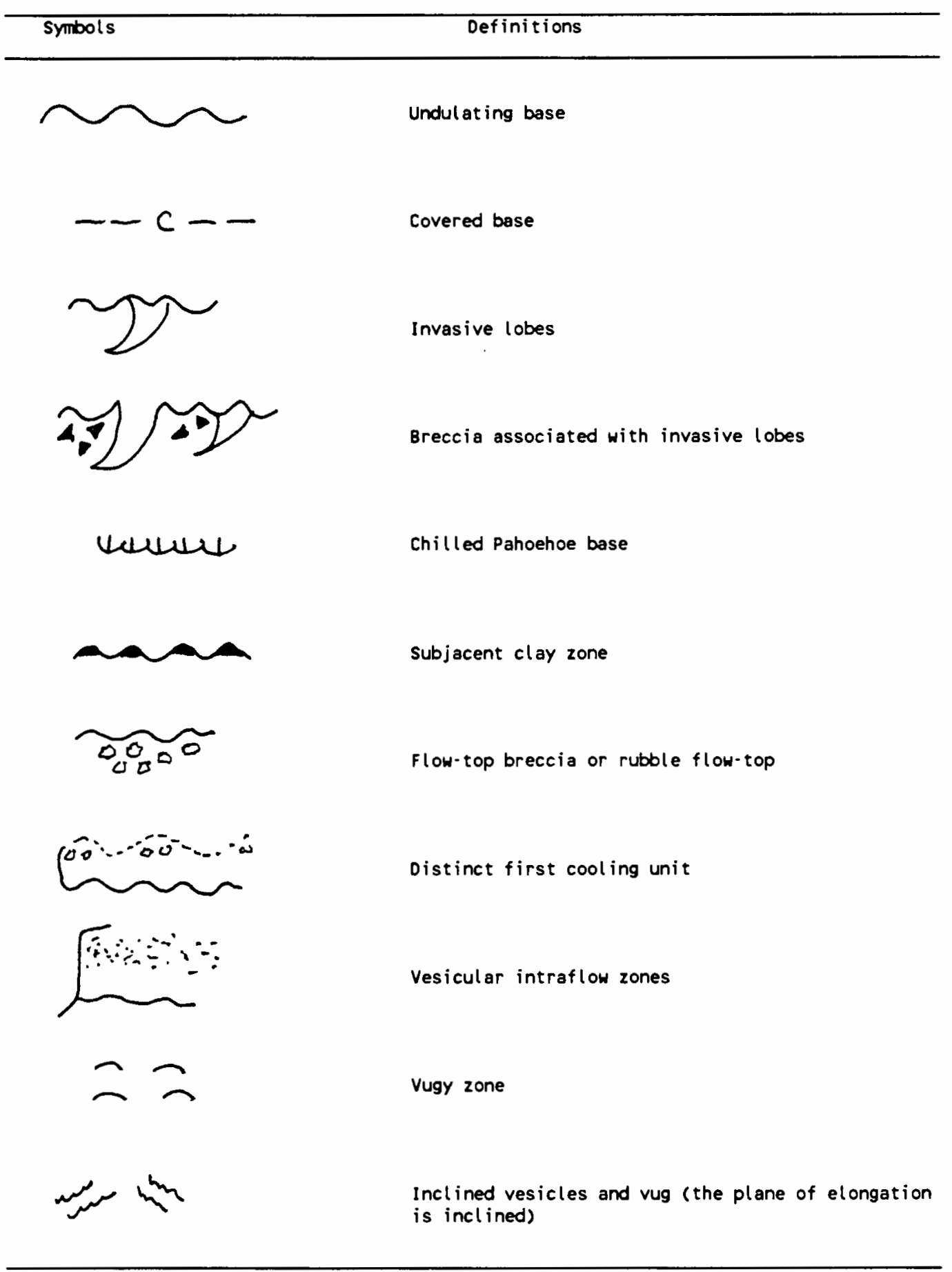


Table XIV CONTINUED

OEFINITIONS FOR SYMBOLS USED IN STRATIGRAPHIC SECTIONS

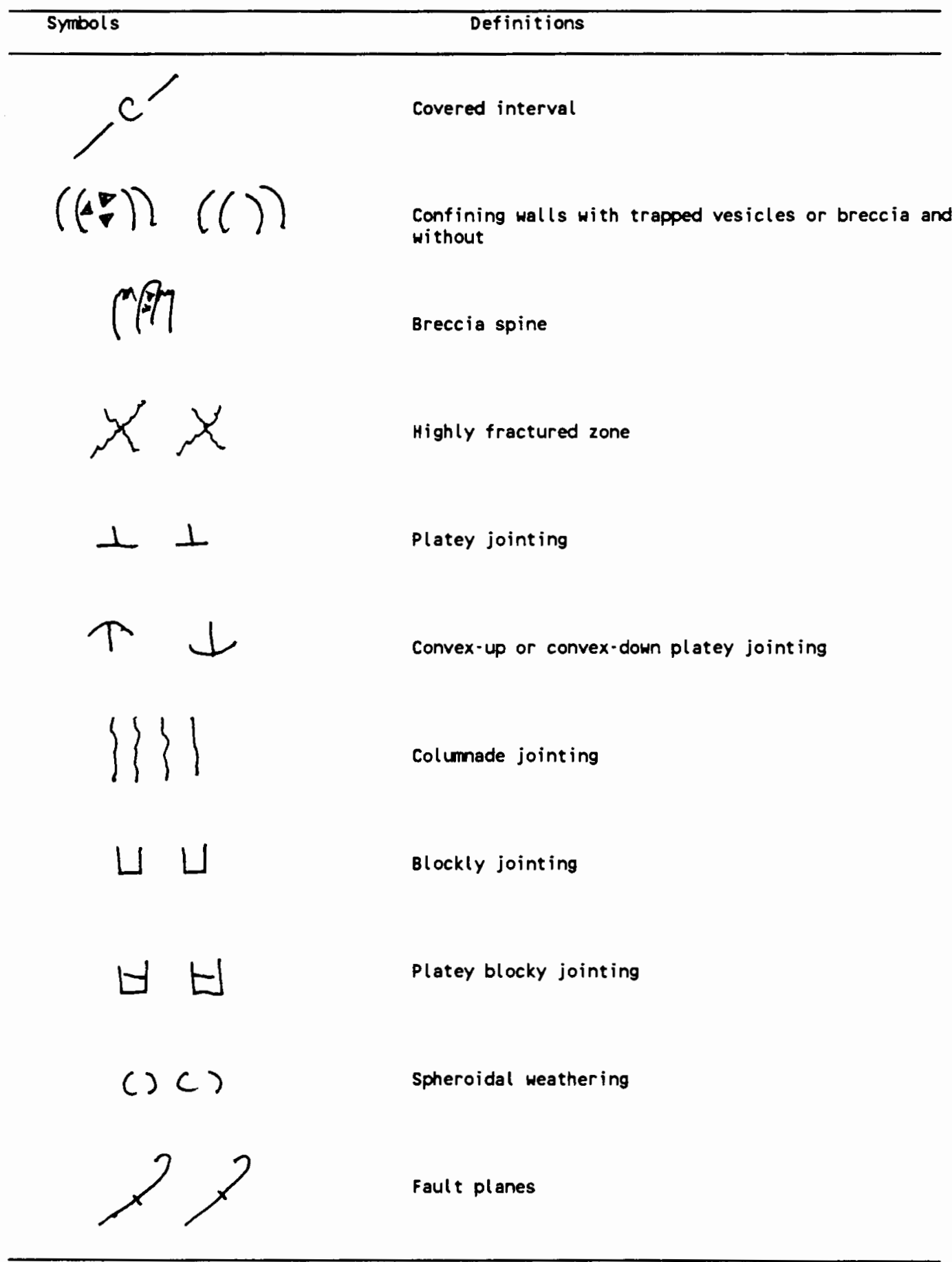


Table XIV CONTINUED

DEFINITIONS FOR SYMBOLS USED IN STRATIGRAPHIC SECTIONS

\begin{tabular}{cl}
\hline Symbols & Definitions \\
\hline SU & Stratigraphic formation \\
UN & Flow name \\
GR & Grand Ronde Basalt \\
T & Troy flow \\
W & Wanapum Basalt \\
SM & Saddle Mountains Basalt \\
\hline
\end{tabular}




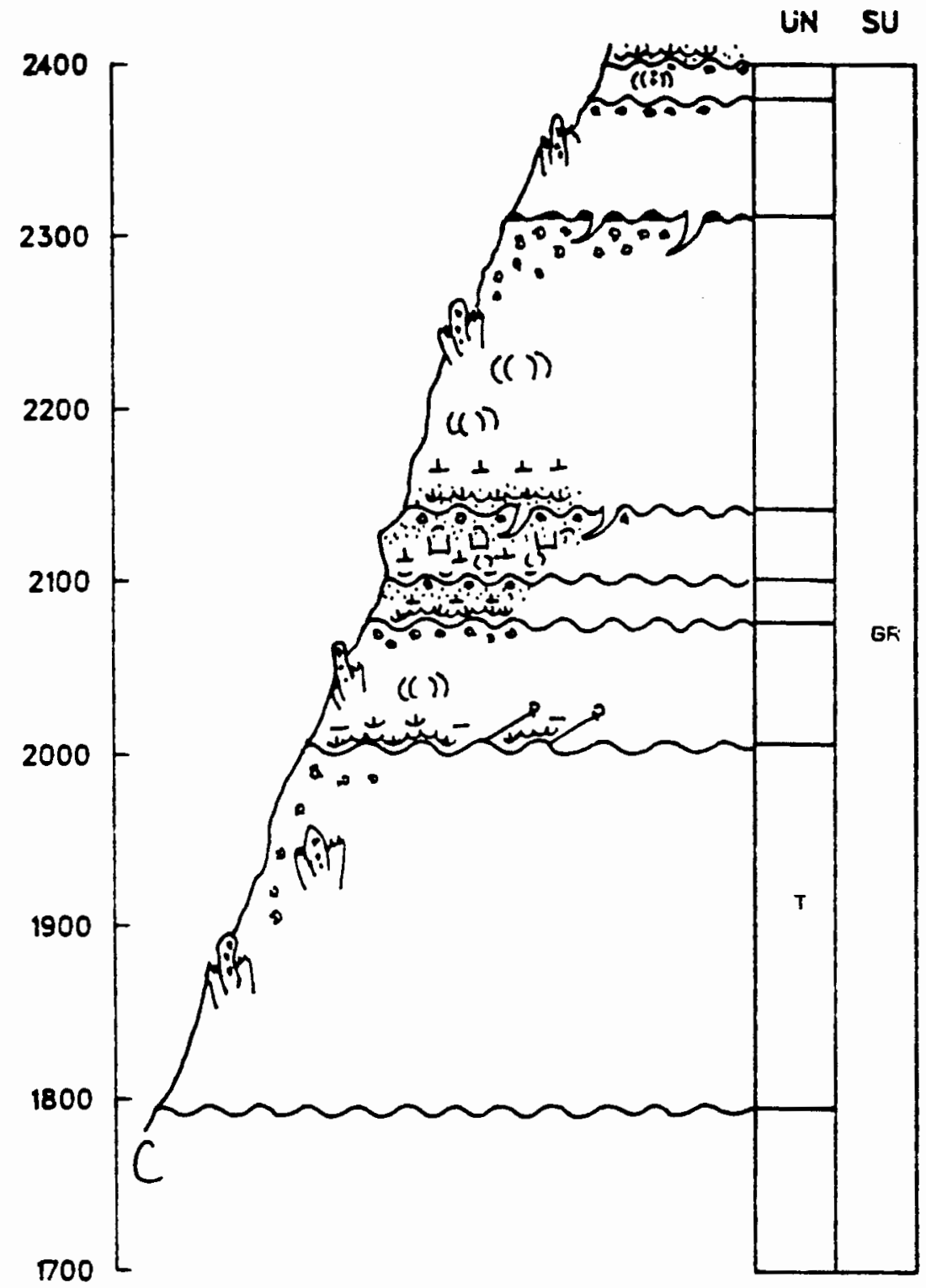

Figure 35. Eden Bench section (EB). 


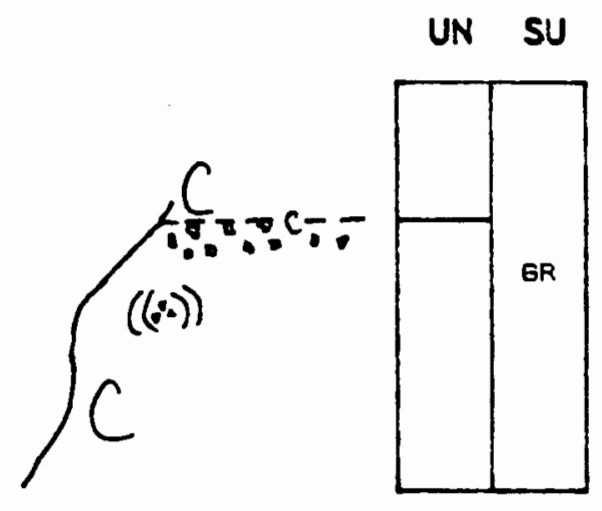

Figure 35. Eden Bench section (EB) continued. 


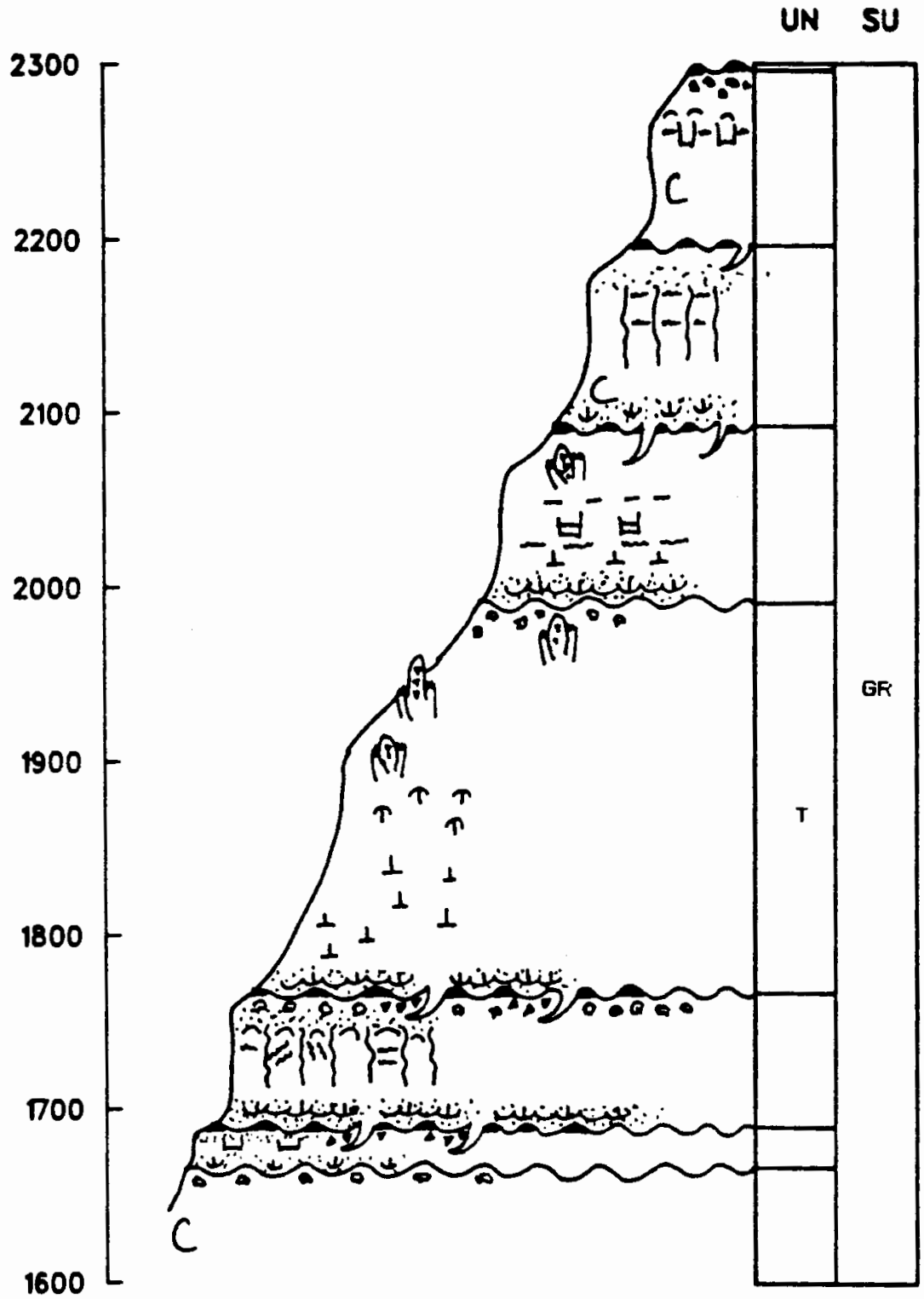

Figure 36. Wenaha Camp section (WC). 


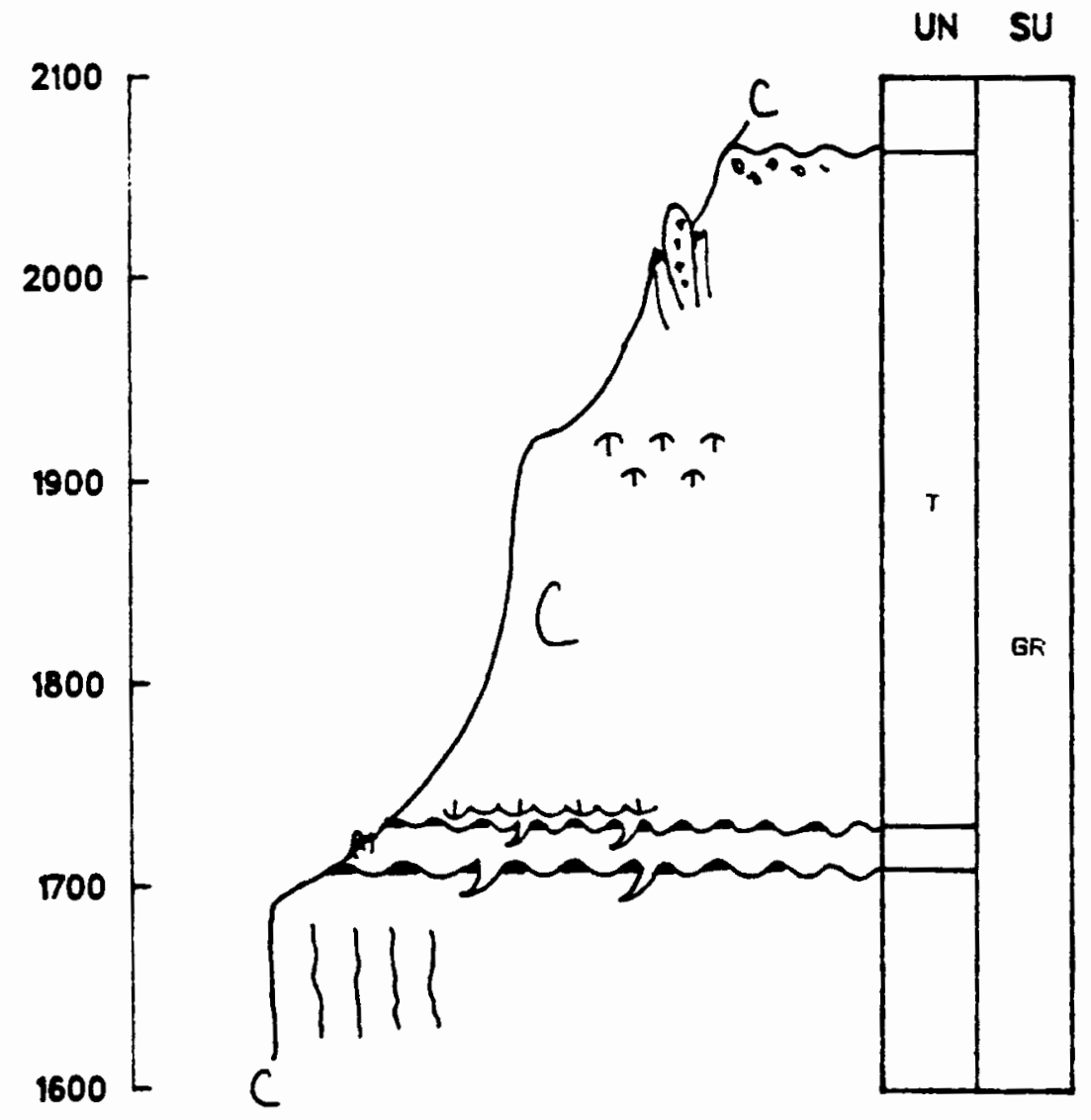

Figure 37. Wenaha Camp Road section (WCR). 


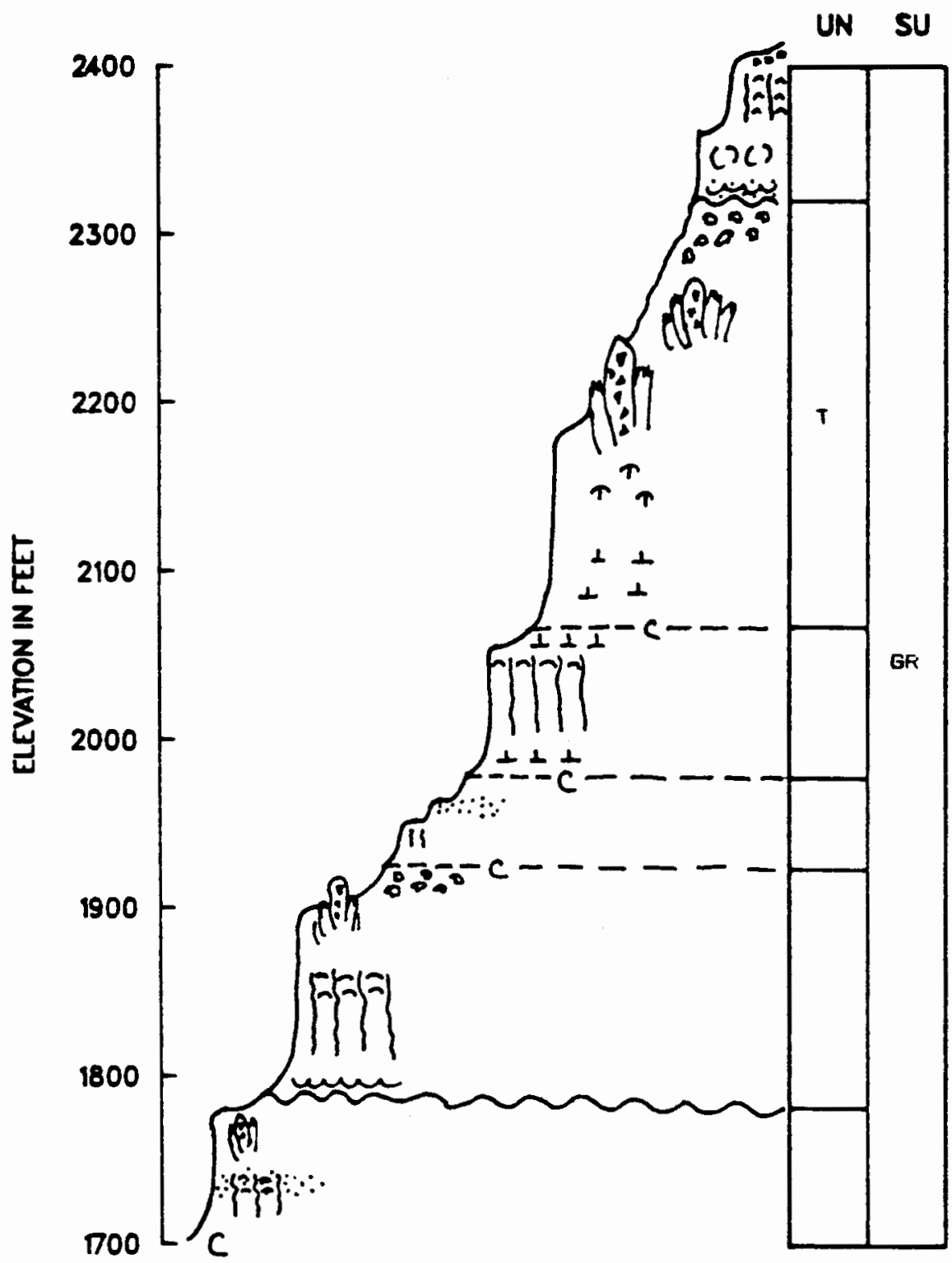

Figure 38. Umatilla section (U). 


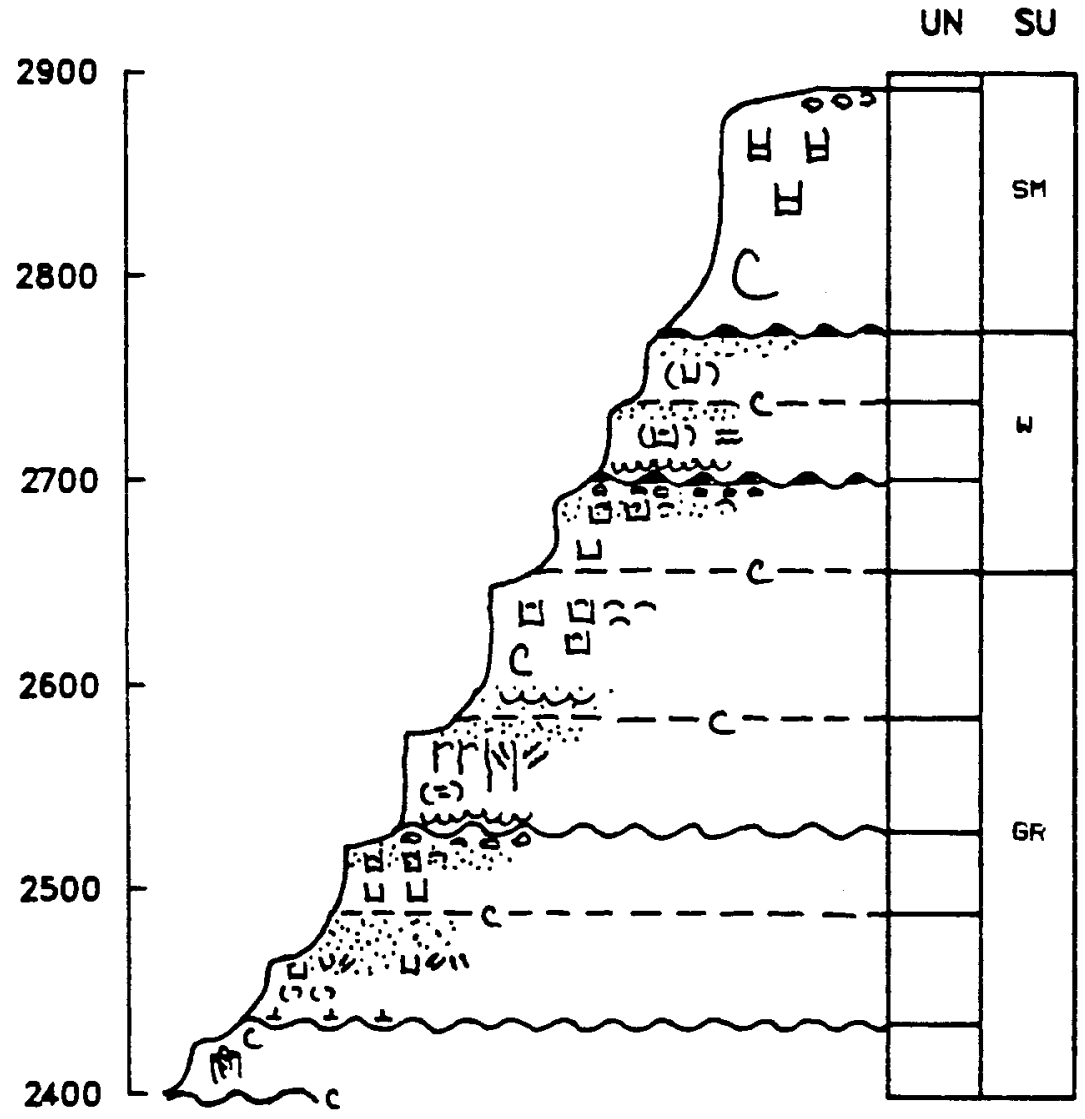

Figure 38. Umatilla section (U) continued. 


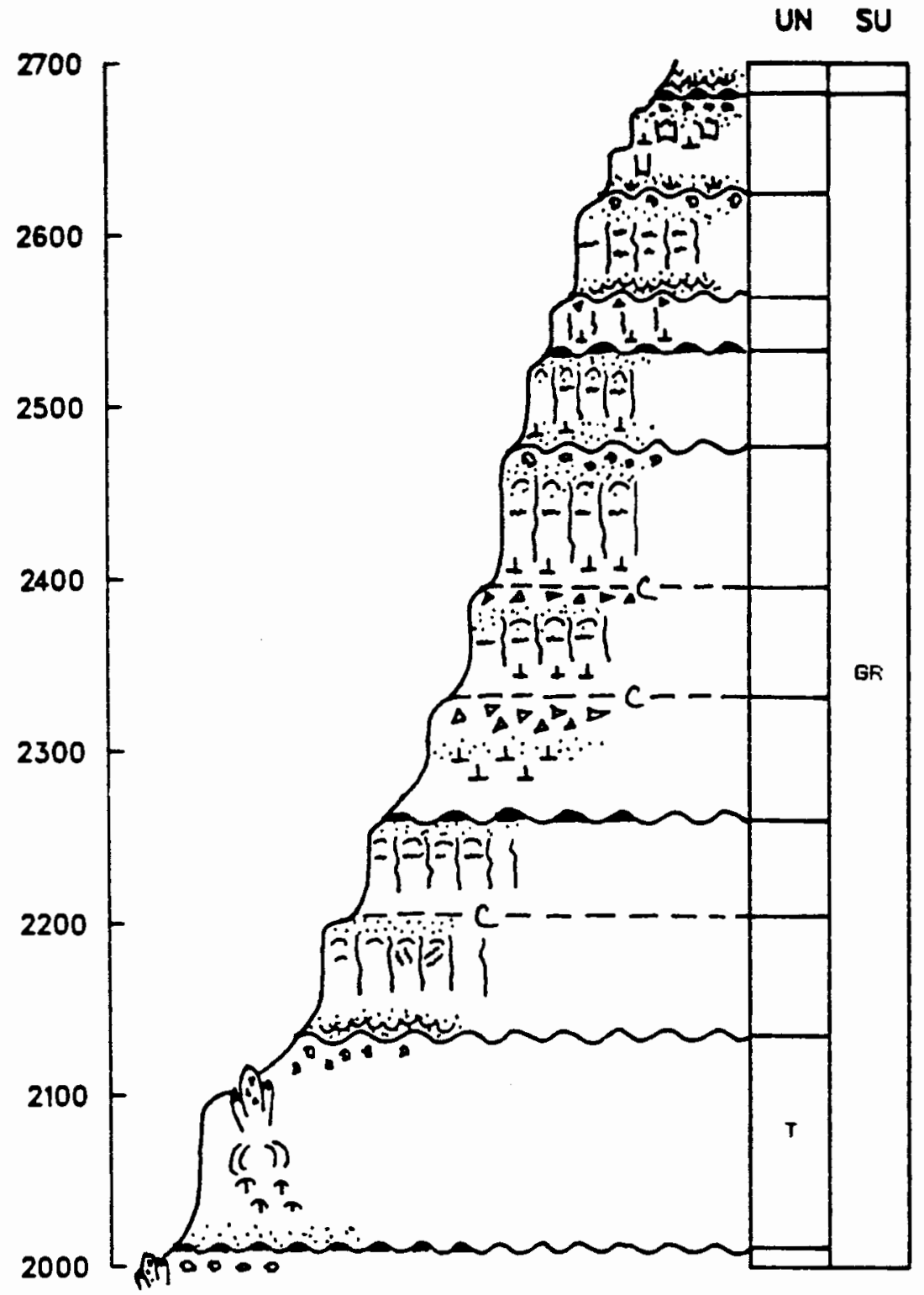

Figure 39. Crooked Creek section (CC). 


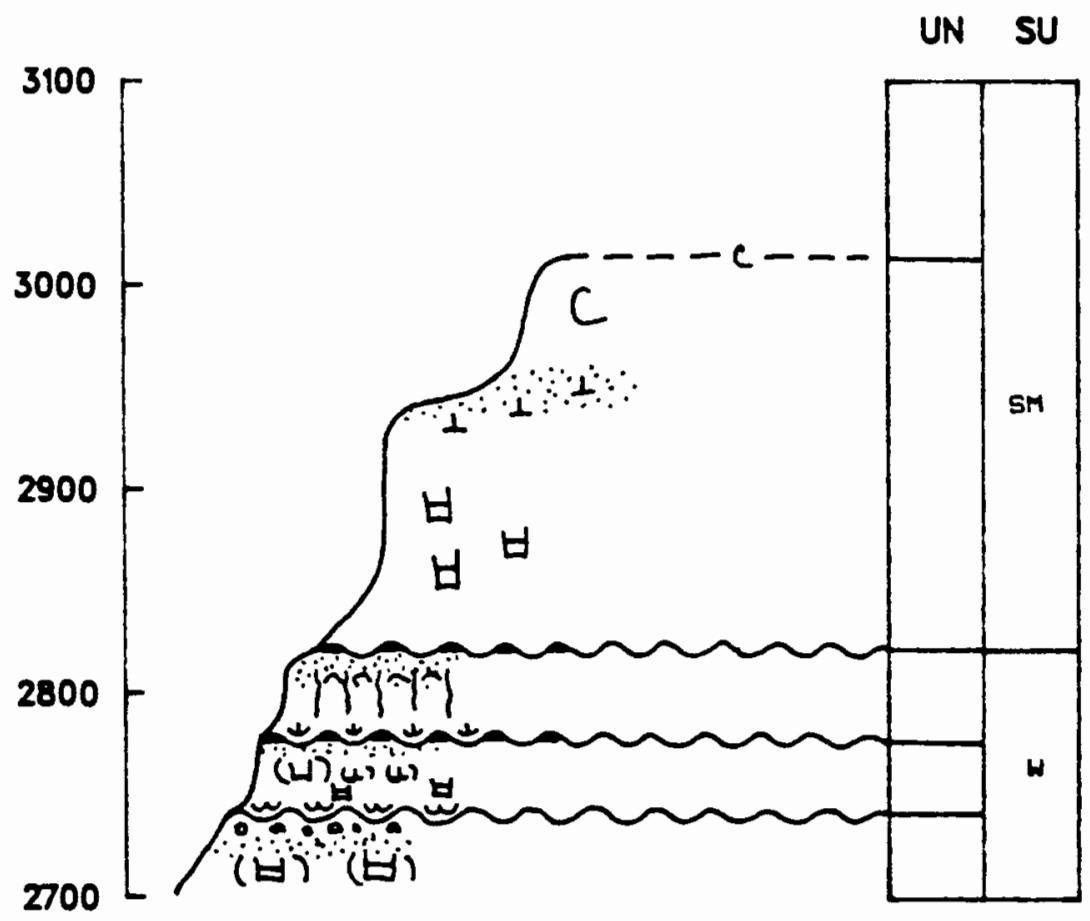

Figure 39. Crooked Creek section (CC) continued. 


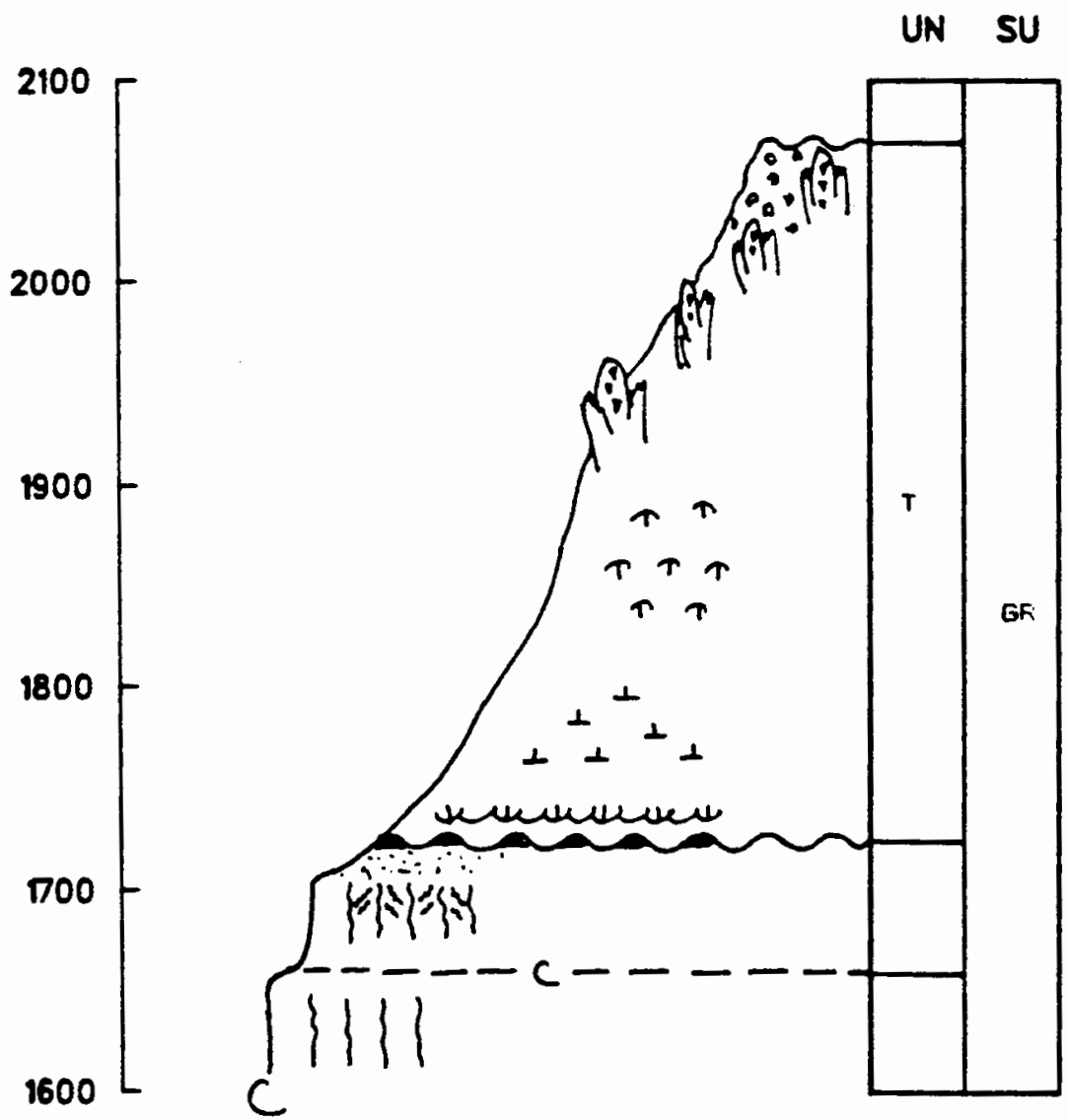

Figure 40. South Wenaha section (SW). 


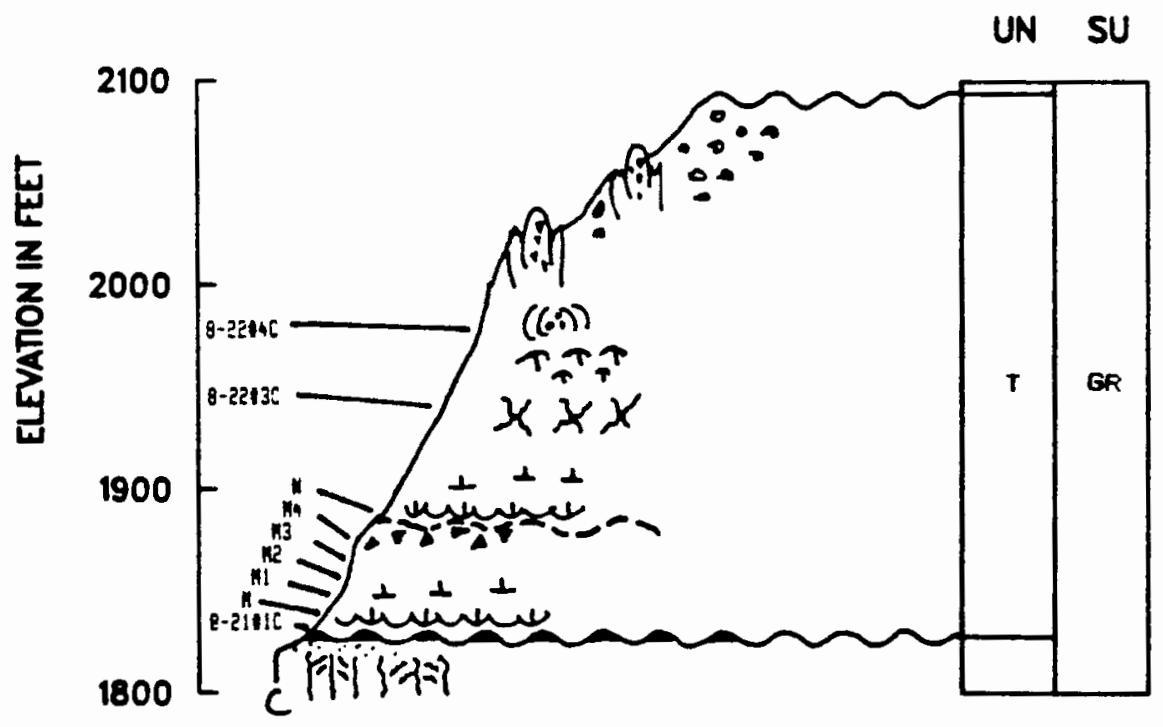

Figure 41. Wenaha Ravine section (W). 


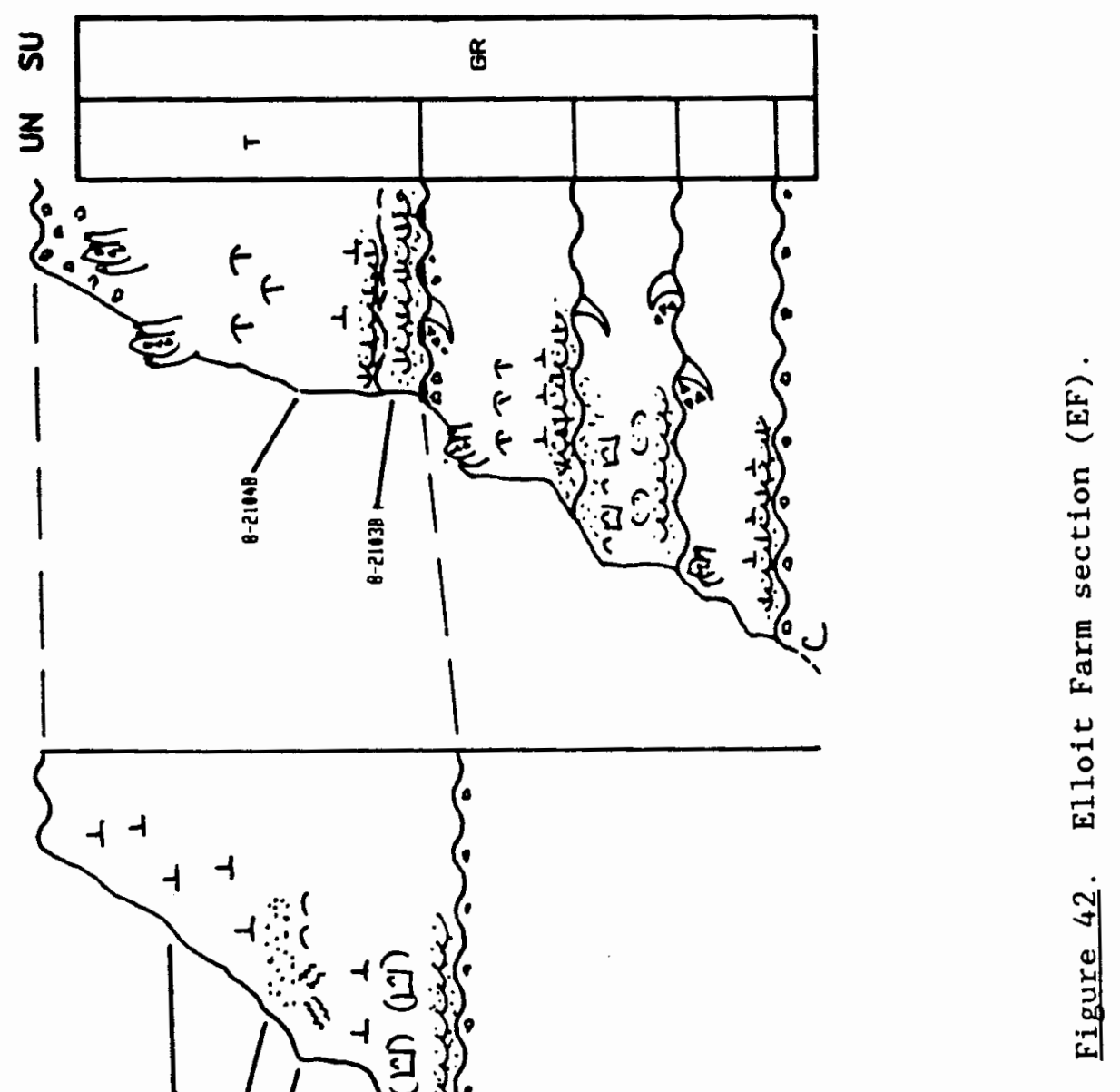




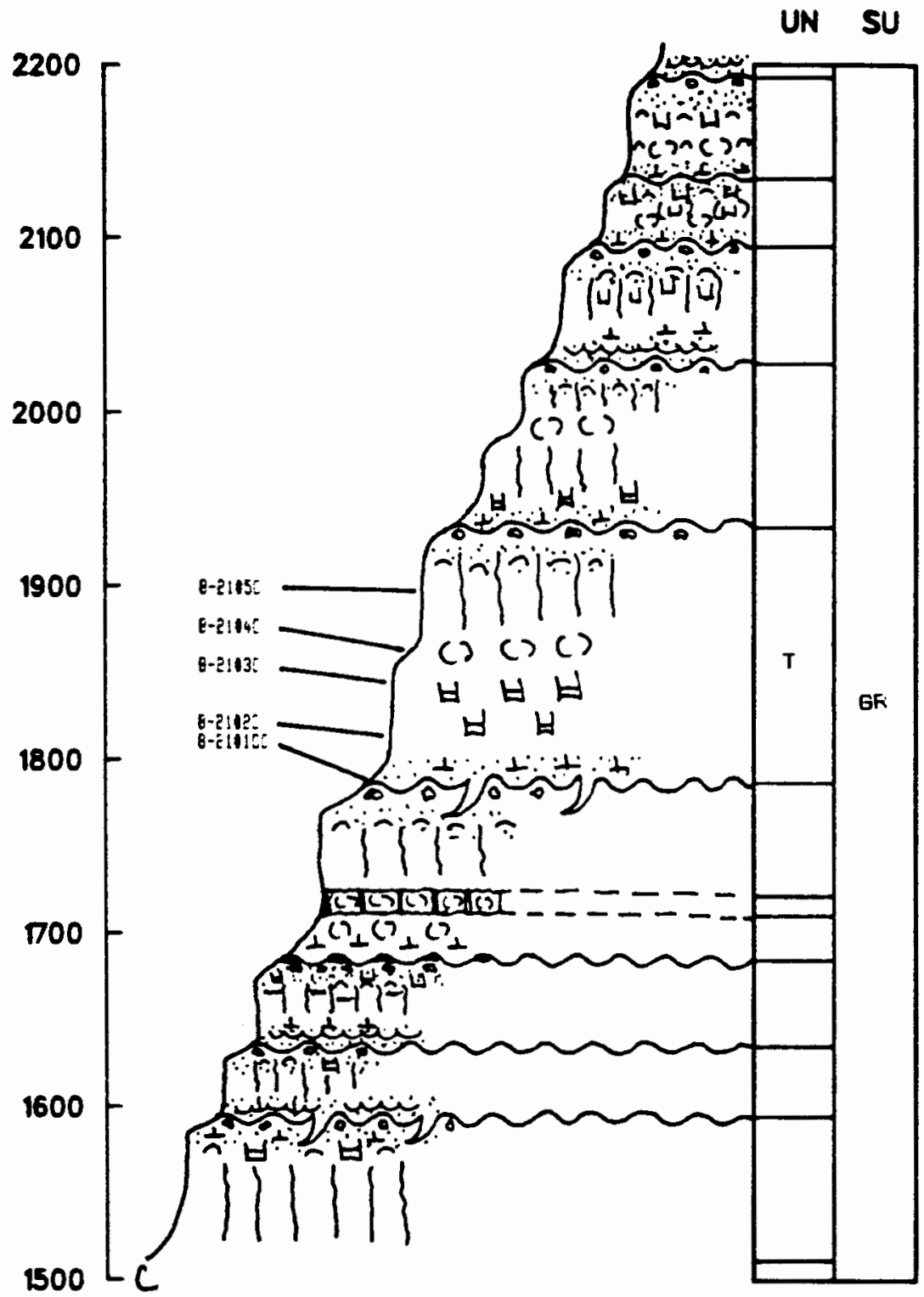

Figure 43. Grouse Creek section (GC). 


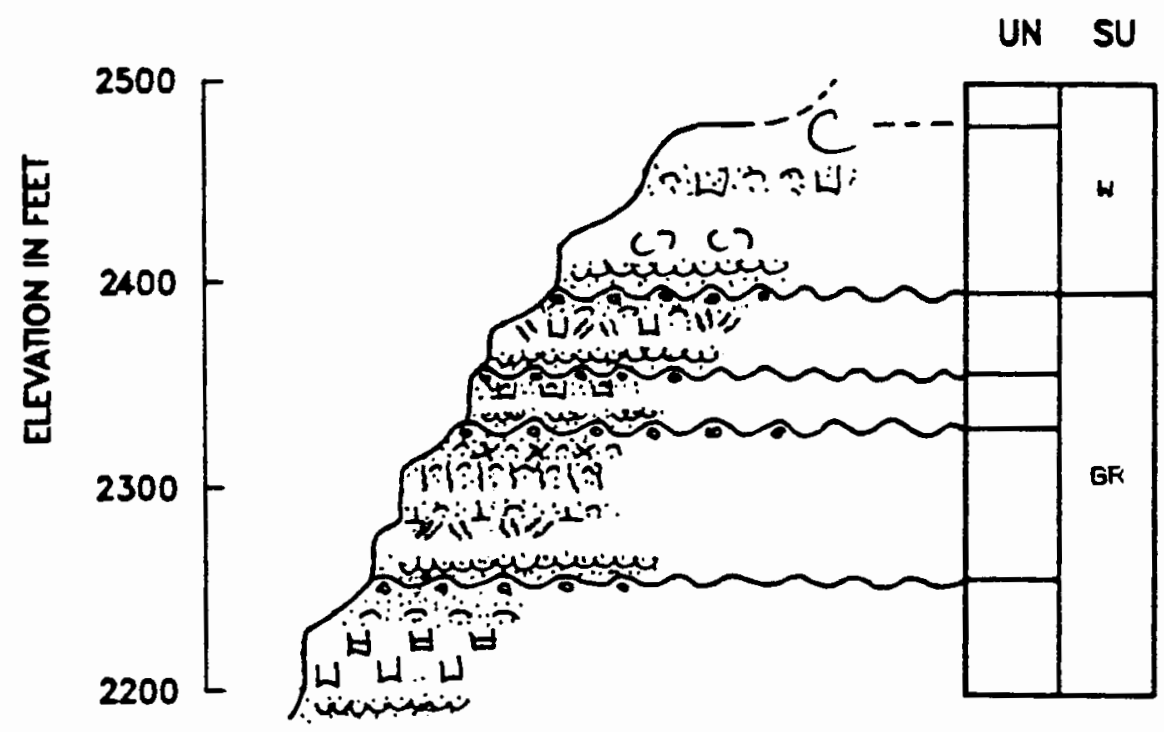

Figure 43. Grouse Creek section (GC). 


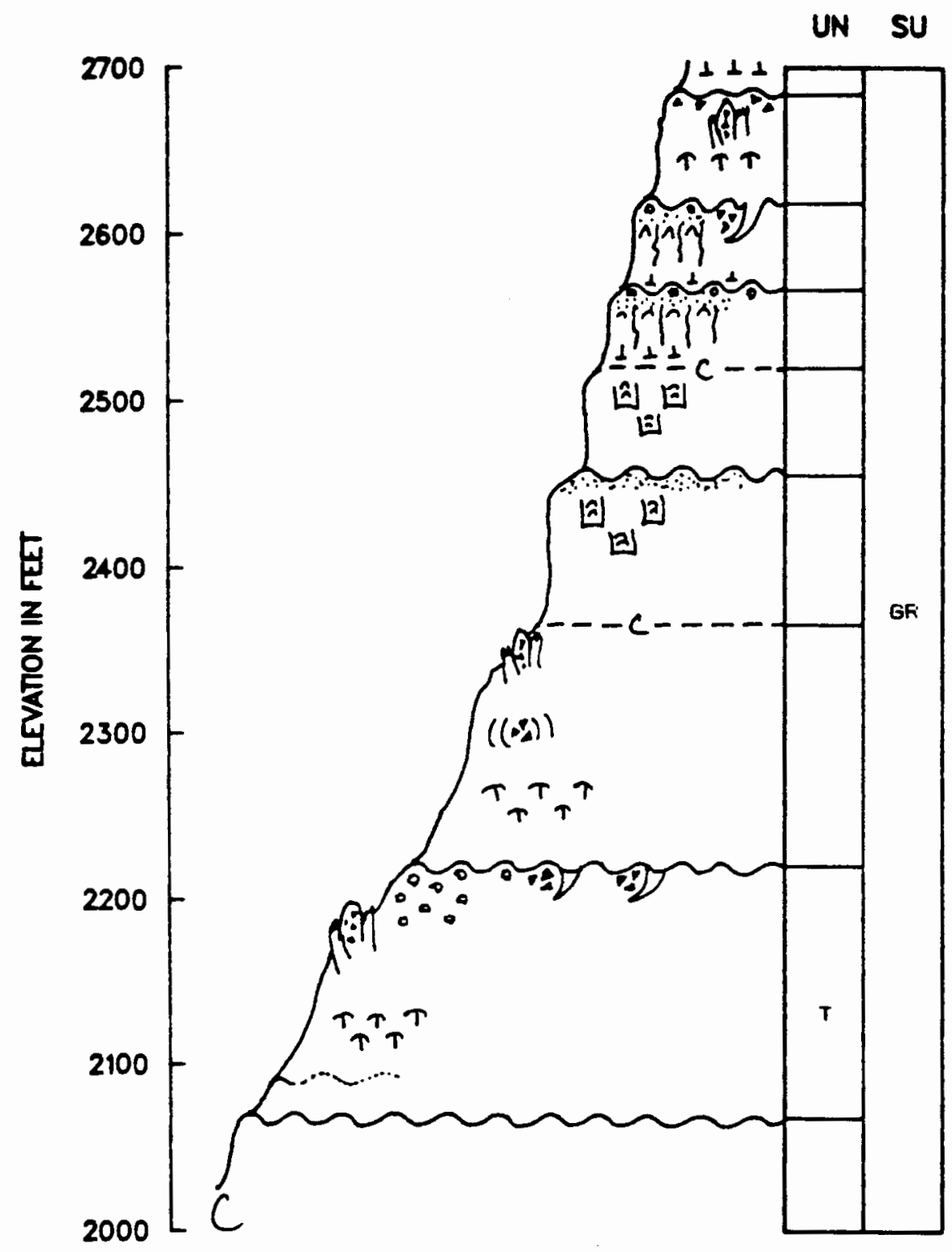

Figure 44. Hoodoo Trail section (H). 


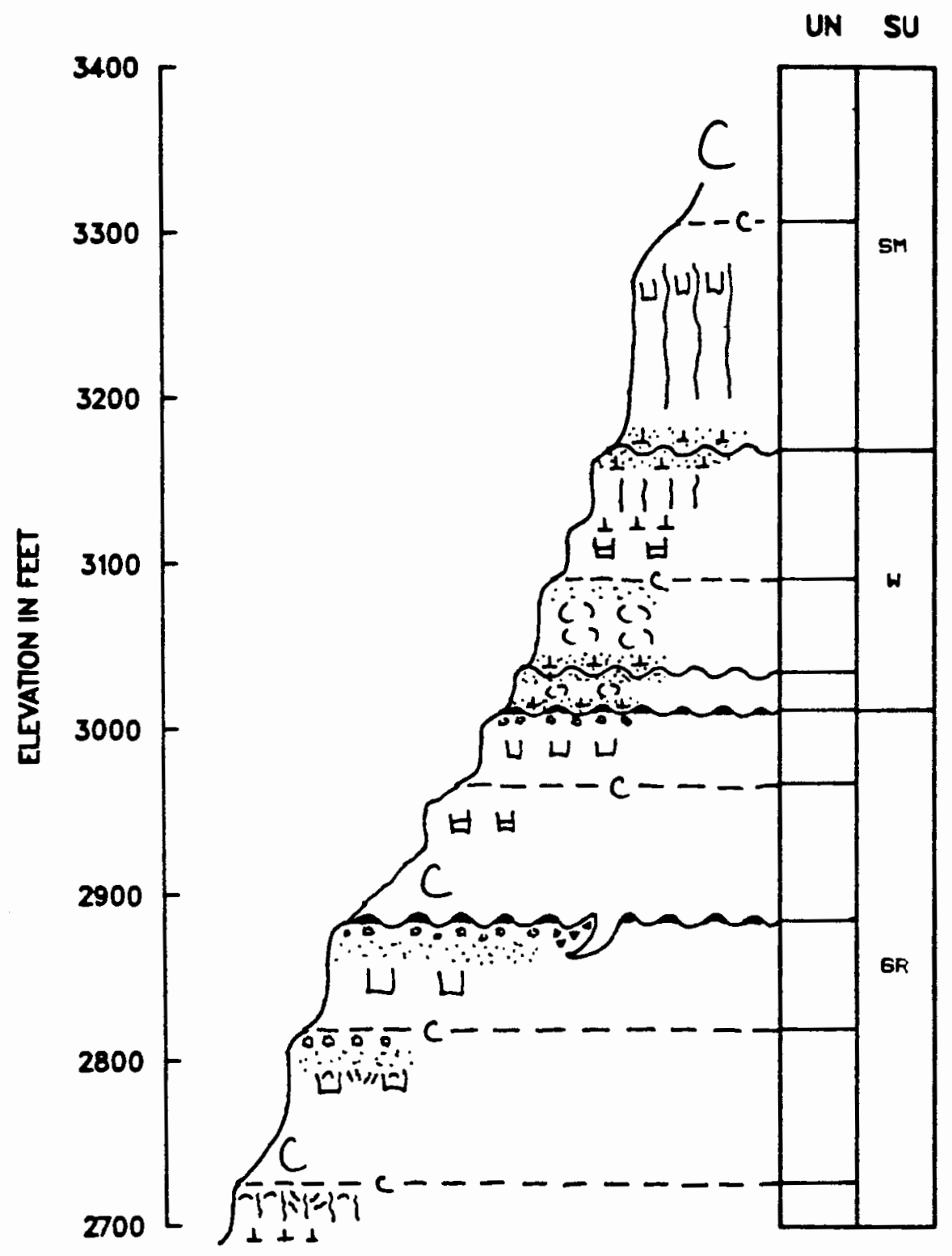

Figure 44. Hoodoo Trail section (H) continued. 


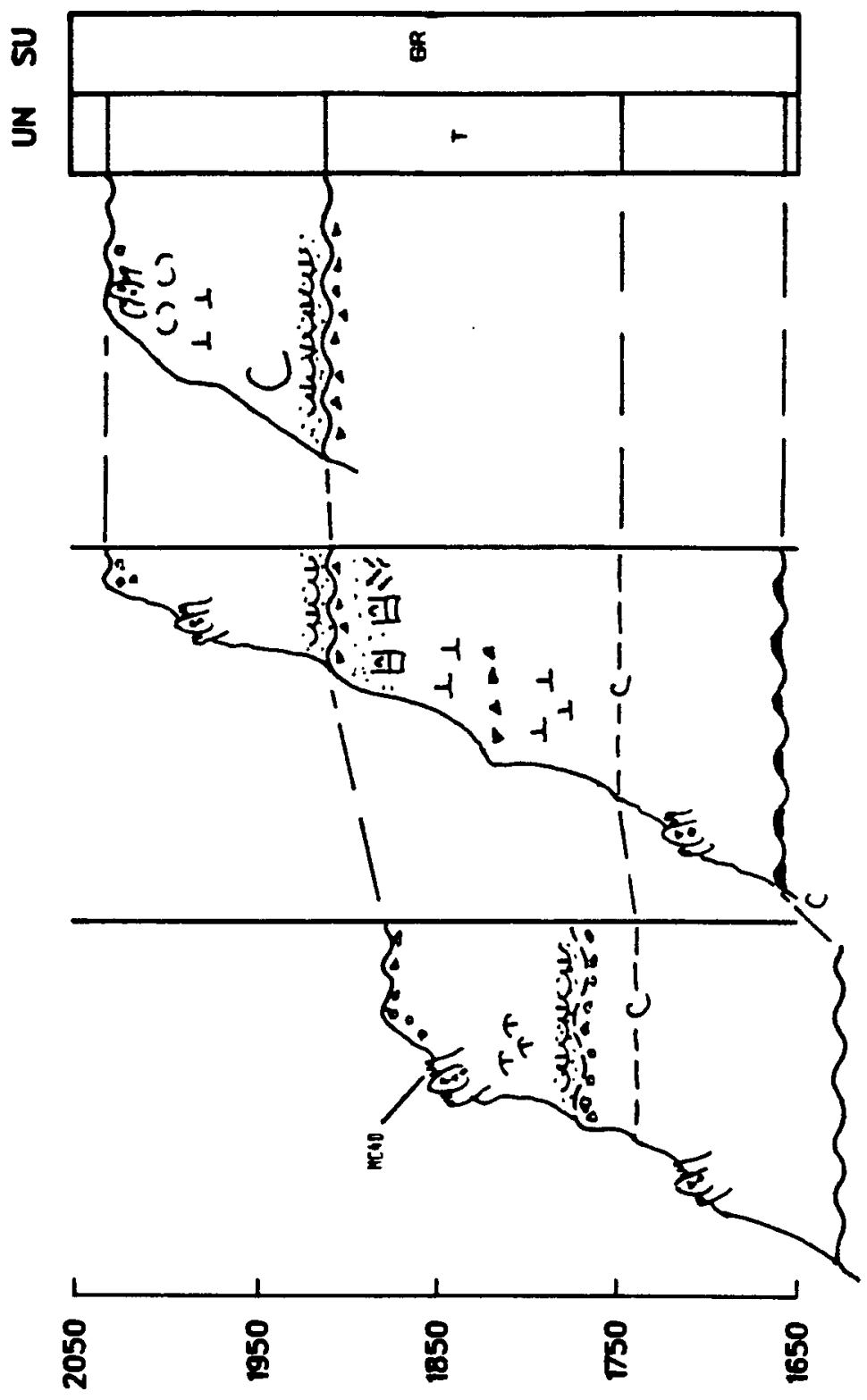

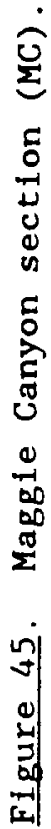

1334 NI NOLVAJI 


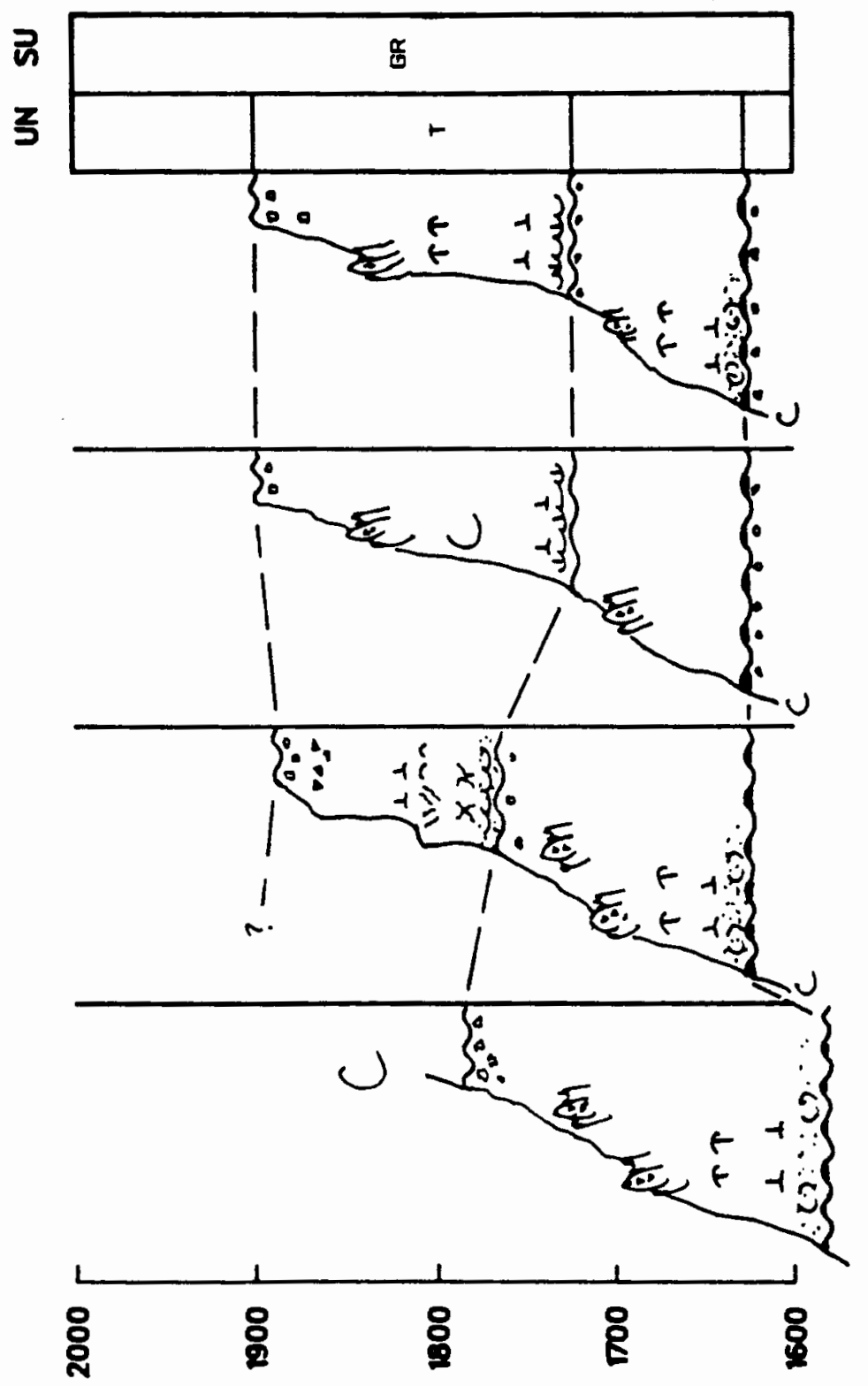

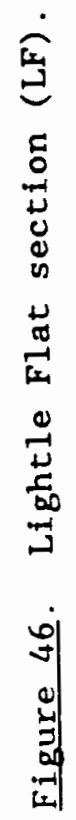

133 NI NOUVAT3 


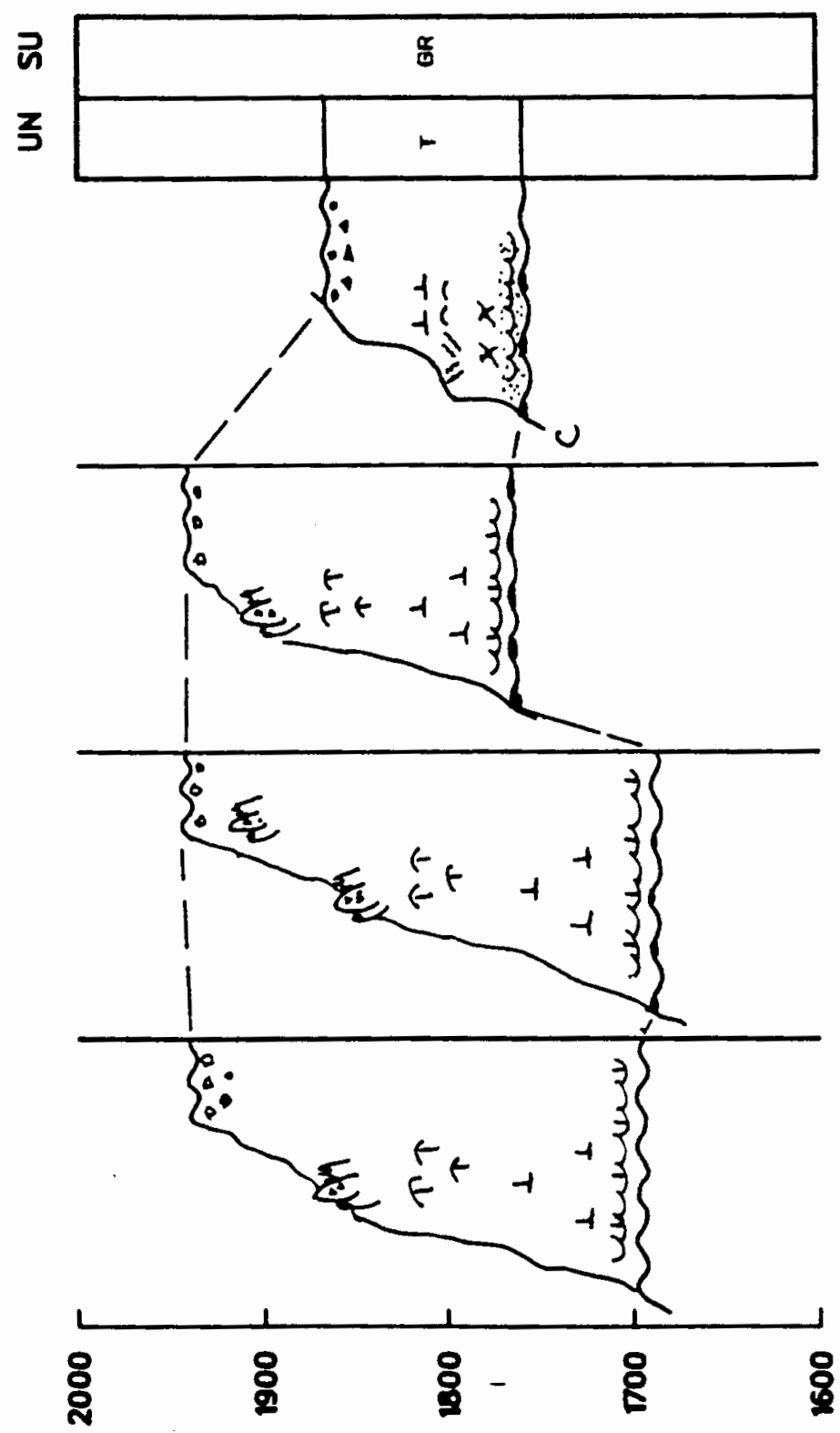

告

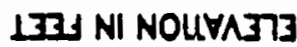



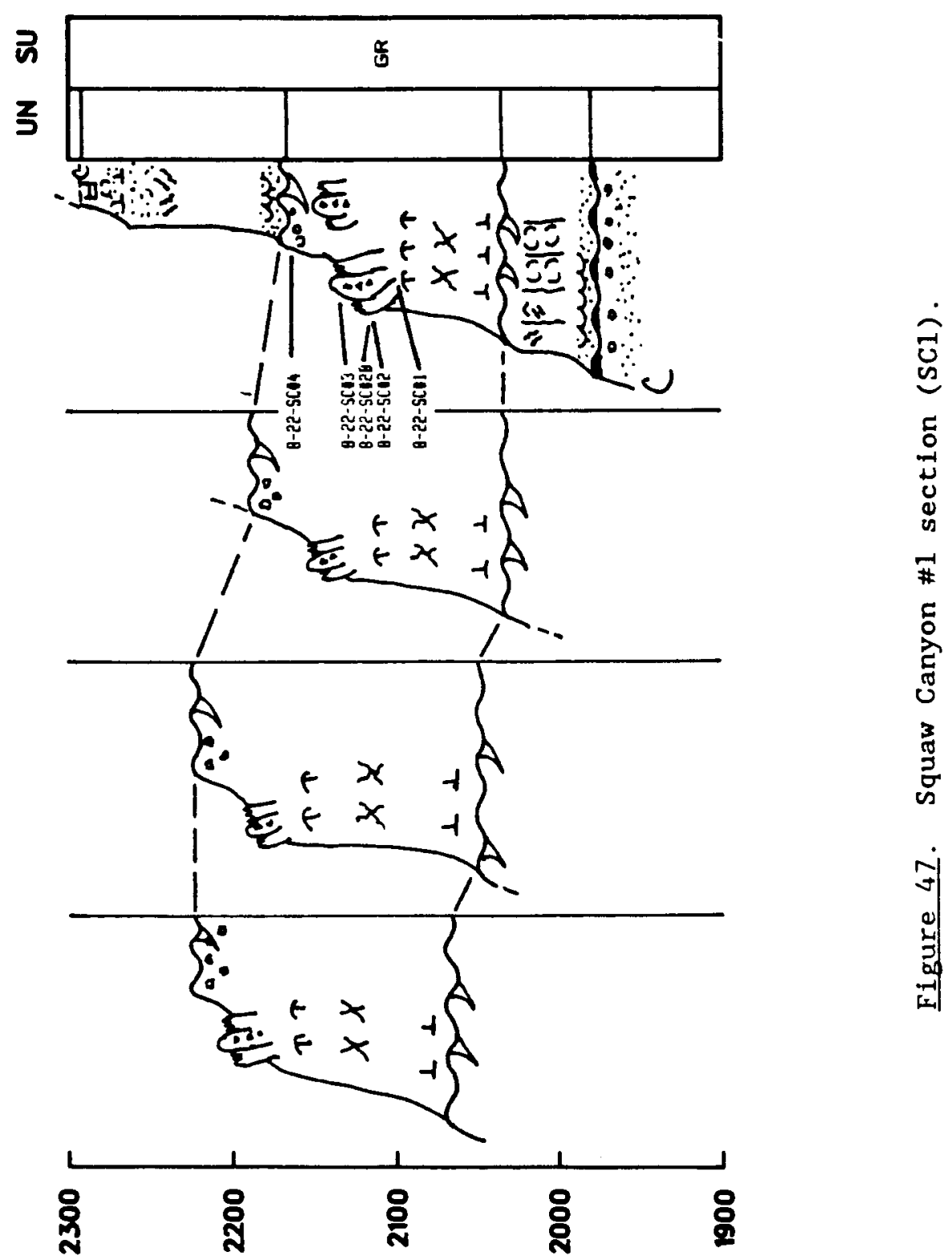

173] NI NOLYAJ73 


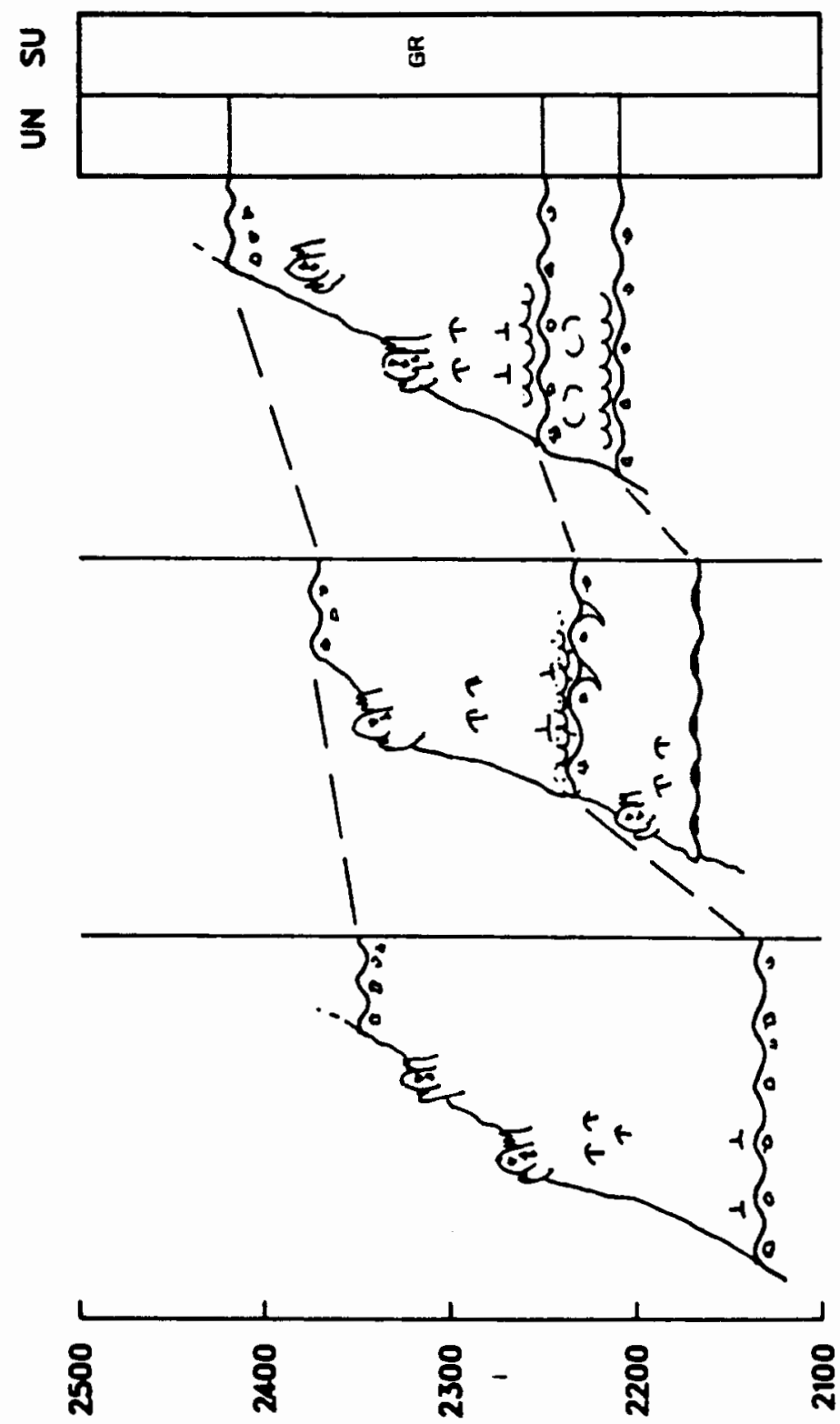

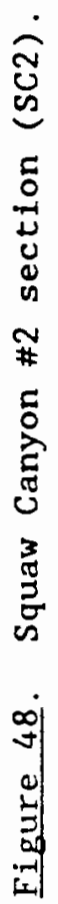

1335 NI NOLVAJ73 


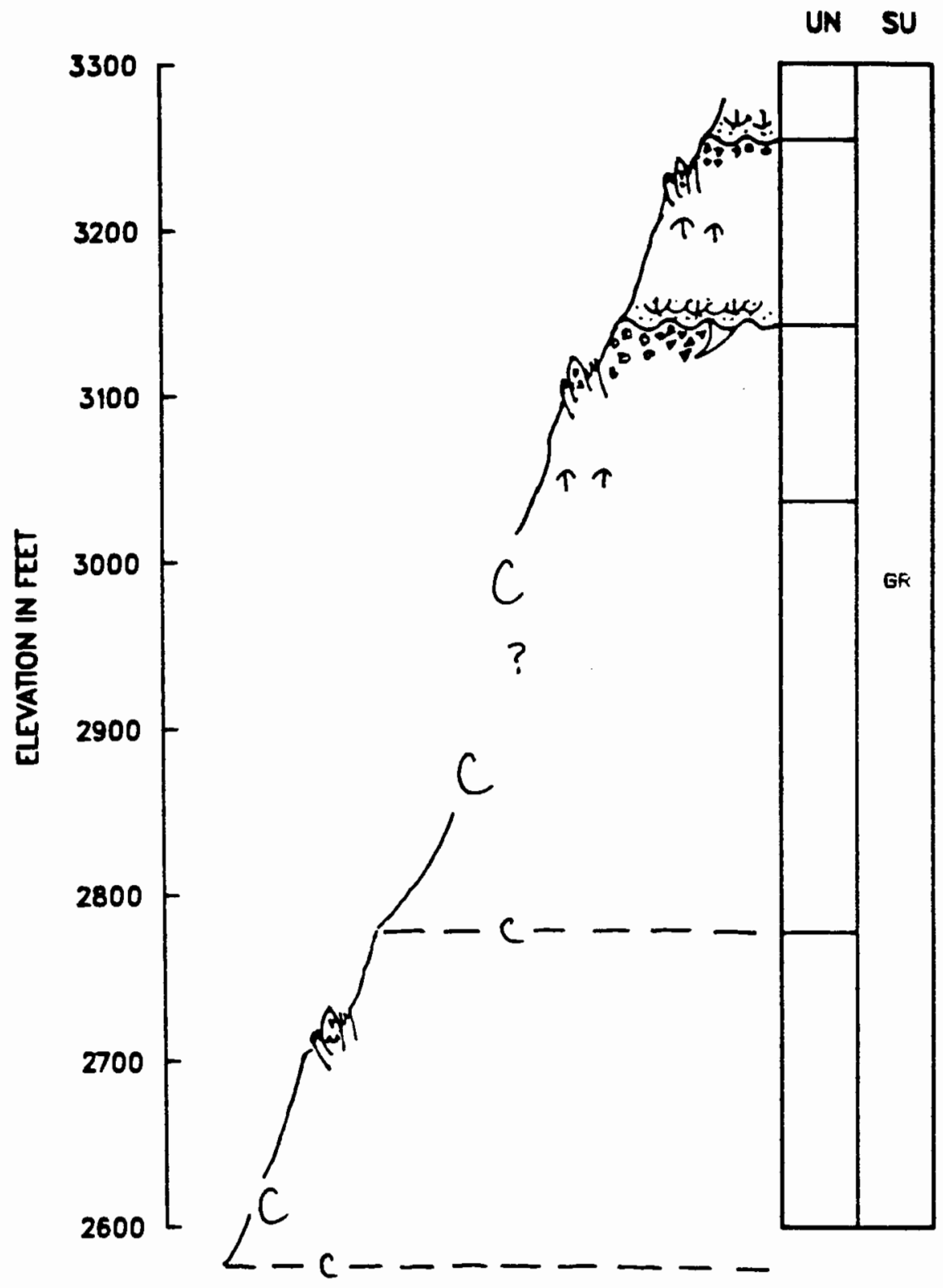

Figure 49. Flora Grade section (F). 


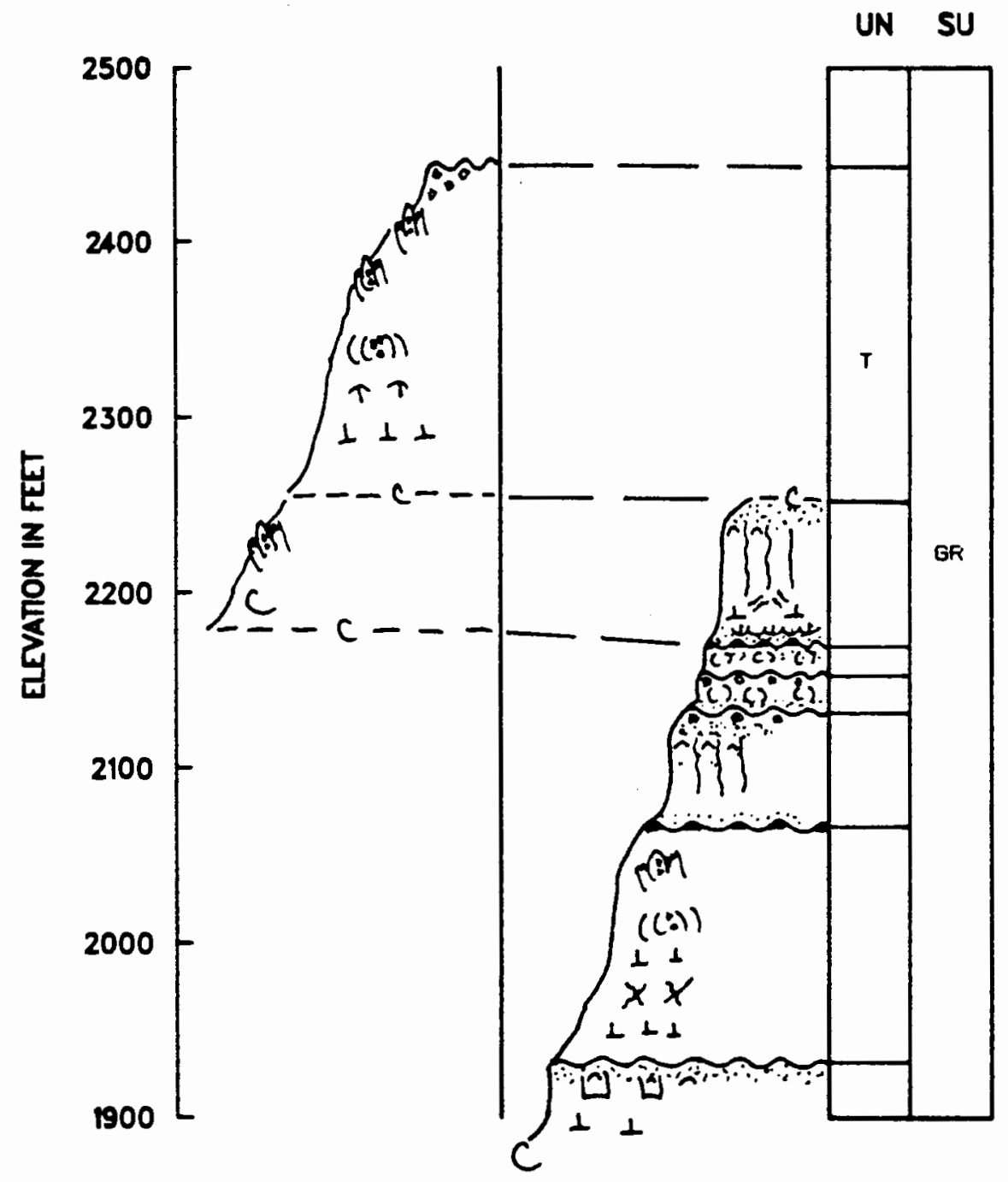

Figure 50. South Grande Ronde section (SG). 


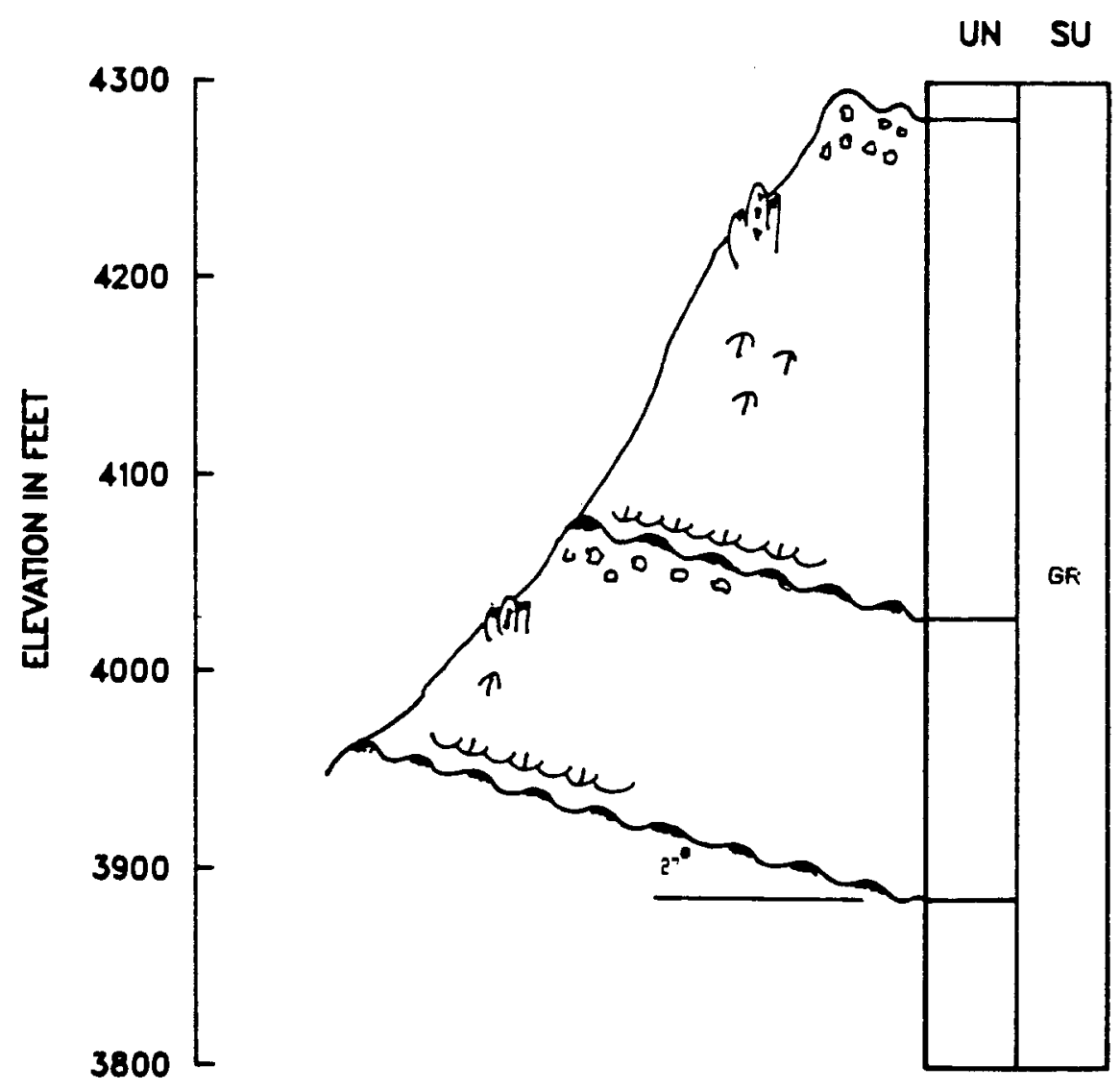

Figure 51. Saddle Mountain section (SM). 


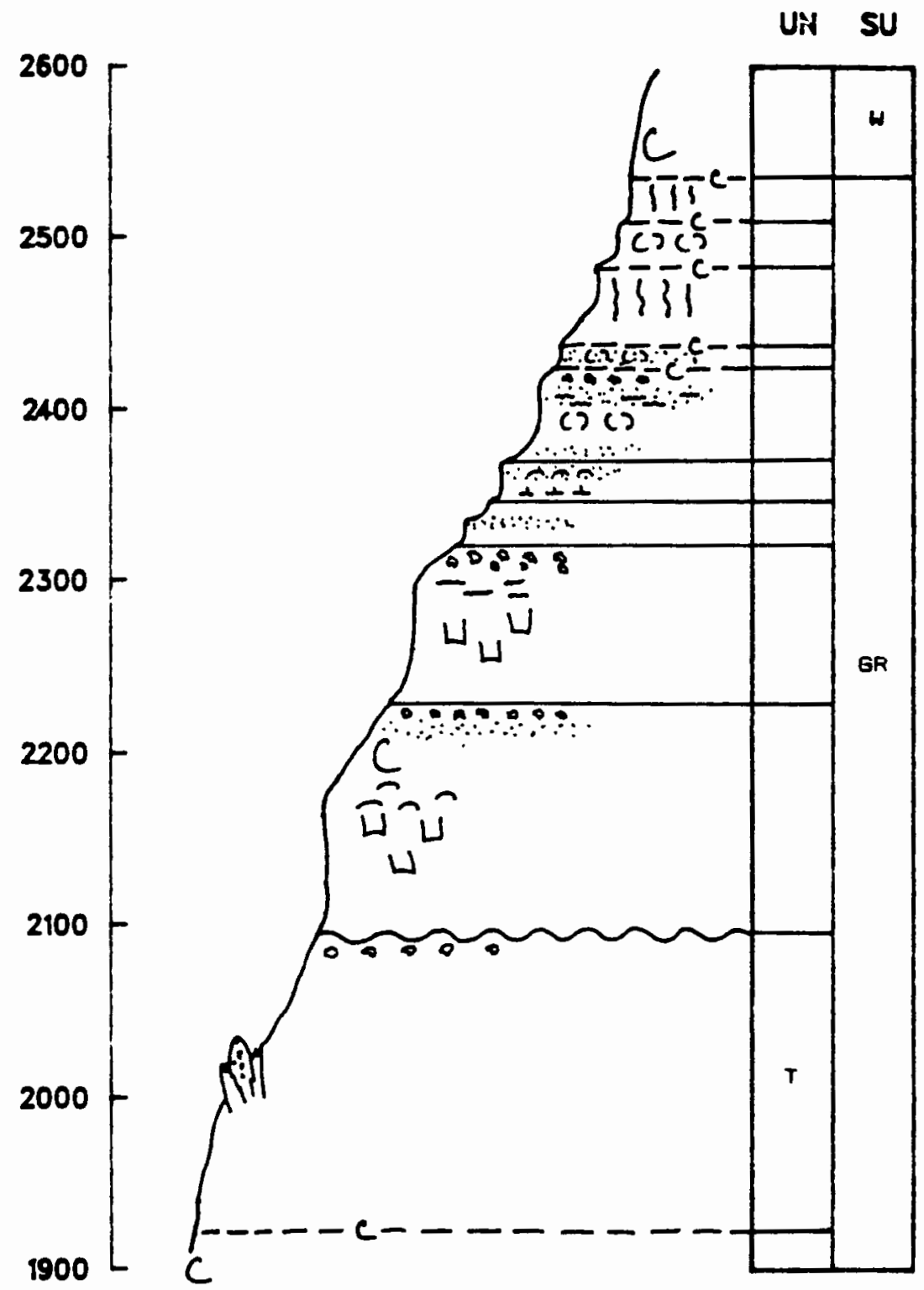

Figure 52. Wenaha River section (W). 

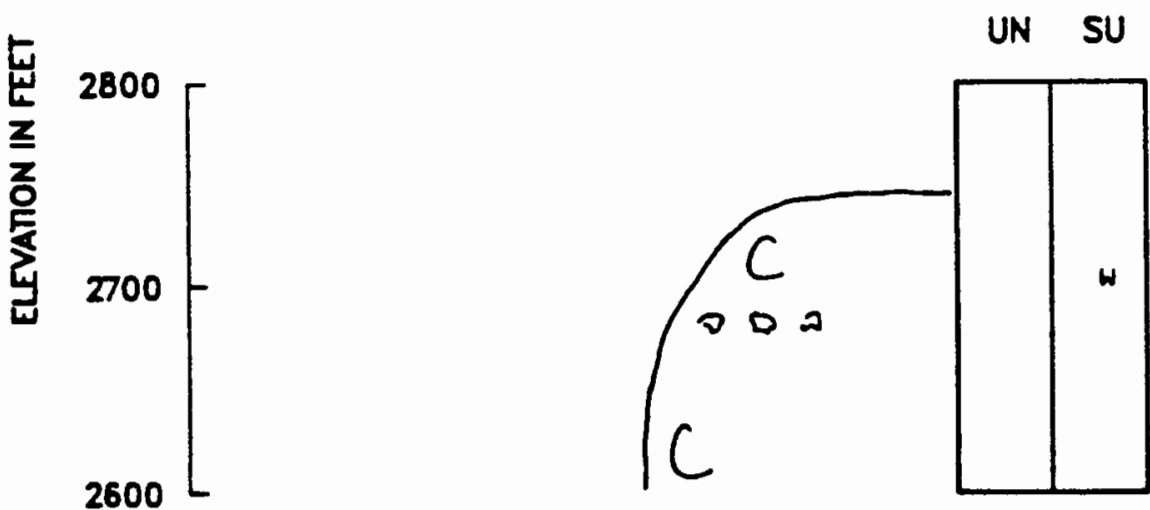

Figure 52. Wenaha River section (W) continued. 


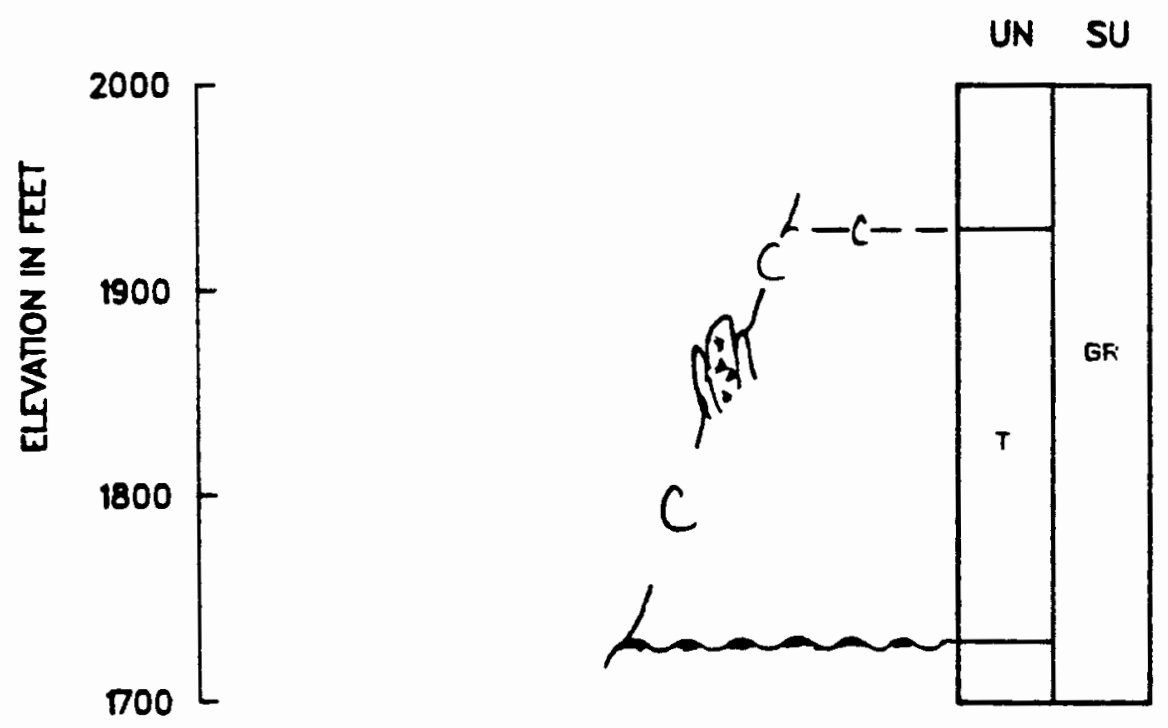

Figure 53. Cougar Creek section (C). 
APPENDIX B

SUMMARY OF PETROGRAPHIC INFORMATION 
TABLE XV

DEFINITIONS OF TERMS USED FOR GROUNDMASS TERMS

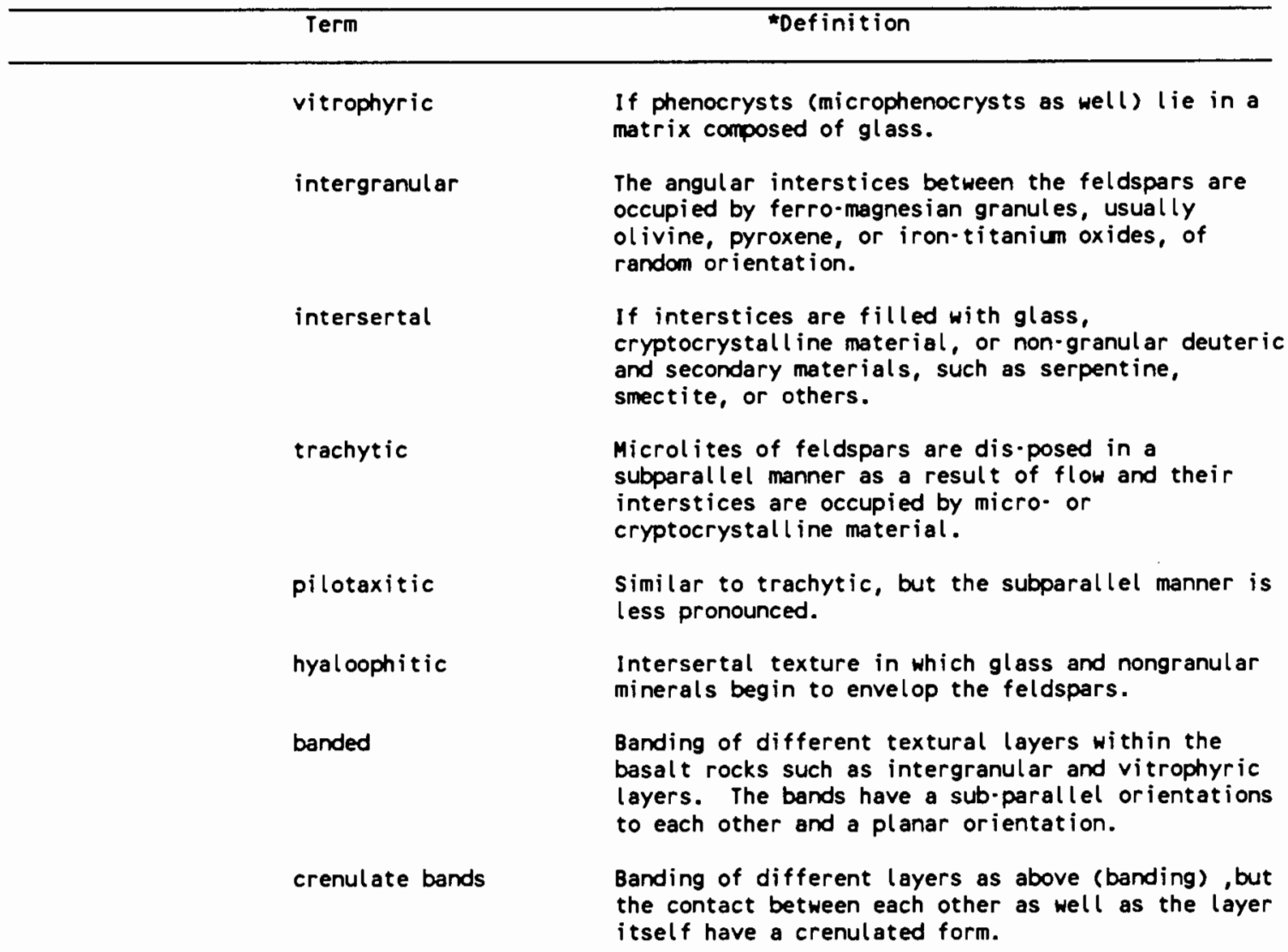

* Definitions taken from Williams, Gilbert, and Turner (1982). 
TABLE XVI

DEFINITIONS USED FOR PHENOCRYSTS AND MICROPHENOCRYSTS

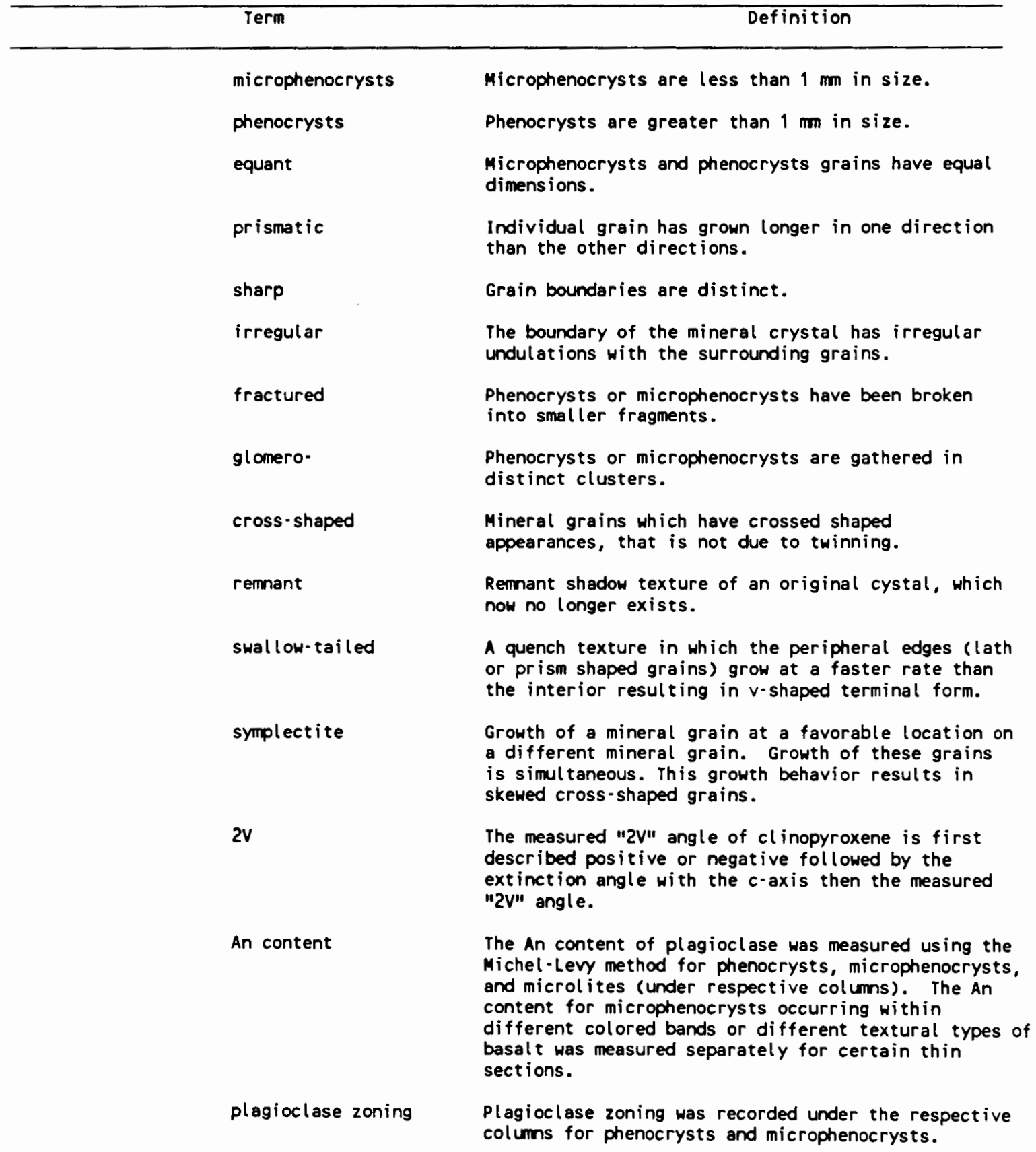


TABLE XVII

DEFINITIONS OF TERMS USED FOR VESICLES

Term

spherical

planar

enl ongated

irregular

crenulated

filled

large

random

zones
Definition

Spherical shaped vesicles.

Planar shaped vesicles, that the size of the length dimension is greater than 5 times the width dimension.

Elongated-shaped vesicles, that the size of the length dimension is less than 5 times its width dimension, but still is greater than its width.

Irregularly shaped vesicles where the peripheral surface is marked by sharp undulations of projecting crystalline material from the basalt.

Crenulated-shaped vesicles where the vesicles have been flattened, but the overall form has been crinkled.

These vesicles are filled with secondary materials such as zeolites or opal/quartz.

These vesicles are unusually large compared to the relative sizes (greater than $5 \mathrm{~mm}$ in diameter) found in other thin sections described in this section.

These vesicles are found in a random pattern with in the rock as observed in thin sections.

Concentrations of vesicles are found in zones across the thin section. 
TABLE XVIII

SYMBOLS AND DEFINITIONS FOR ADJECTIVES USED

\begin{tabular}{|c|c|c|}
\hline Symbol & Term & Definition \\
\hline N & not counted & $\begin{array}{l}\text { Phenocrysts or microphenocrysts were observed, but } \\
\text { were not included during the counting process. }\end{array}$ \\
\hline $\boldsymbol{H}$ & well developed & $\begin{array}{l}\text { The adjective emphasizes the texture term is } \\
\text { relatively better developed as compared to the same } \\
\text { texture in other thin sections. }\end{array}$ \\
\hline $\mathbf{P}$ & poorly developed & $\begin{array}{l}\text { The opposite of well-developed. The term is } \\
\text { relative to other thin sections. }\end{array}$ \\
\hline$R / R$ & specific banding & $\begin{array}{l}\text { A specific type of color banding in which the } \\
\text { layers are both red colored when observed with the } \\
\text { nake eye. }\end{array}$ \\
\hline$R / B$ & specific banding & $\begin{array}{l}\text { A specific type of color banding similar to the } \\
\text { above banding, but the layers vary from black } \\
\text { colored to red colored. }\end{array}$ \\
\hline$B / B$ & specific banding & $\begin{array}{l}\text { A specific type of color banding similar to the } \\
\text { above banding, but the layers colored black. }\end{array}$ \\
\hline $\mathbf{R}$ & rare & $\begin{array}{l}\text { A term which describes the relative proportion as } \\
\text { being rare compared to other thin sections. }\end{array}$ \\
\hline v & very & A prefix used to emphasize. \\
\hline$r$ & remant & $\begin{array}{l}\text { A term describing a feature observed within the } \\
\text { groundmass of the thin section consisting of a } \\
\text { concentration of microlitic plagioclase. The } \\
\text { microlitic concentration forms a shape resembling a } \\
\text { phenocryst lath of plagioclase. An eariler formed } \\
\text { plagioclase phenocrysts probably reacted with the } \\
\text { surrounding melt that resulted in these plagioclase } \\
\text { micolites. Ross (1978) noted similar remant } \\
\text { plagioclase features. }\end{array}$ \\
\hline
\end{tabular}


TABLE $X I X$

THIN SECTION DESCRIPTION FOR SAMPLE : M

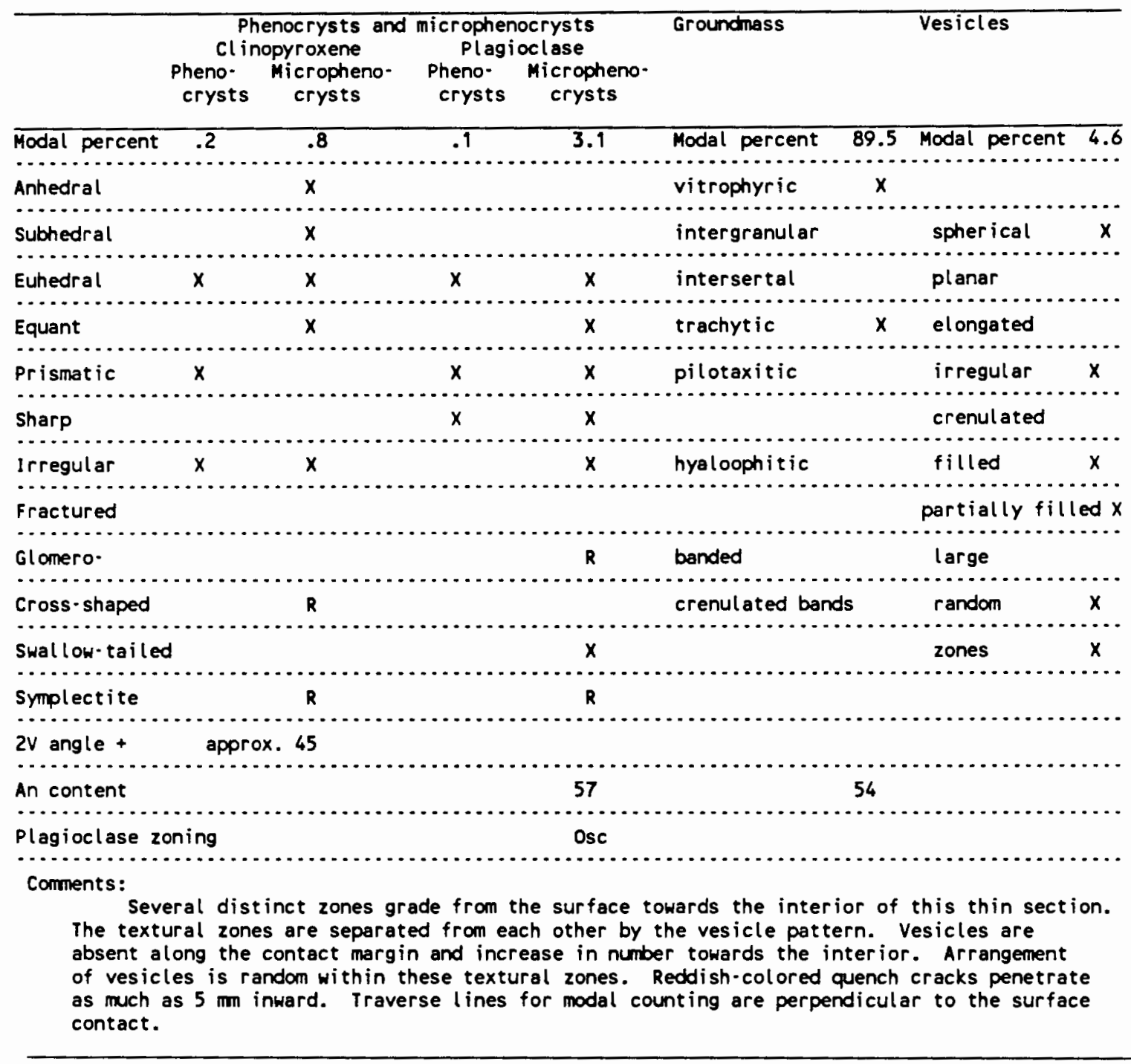


TABLE XX

THIN SECTION DESCRIPTION FOR SAMPLE : M1

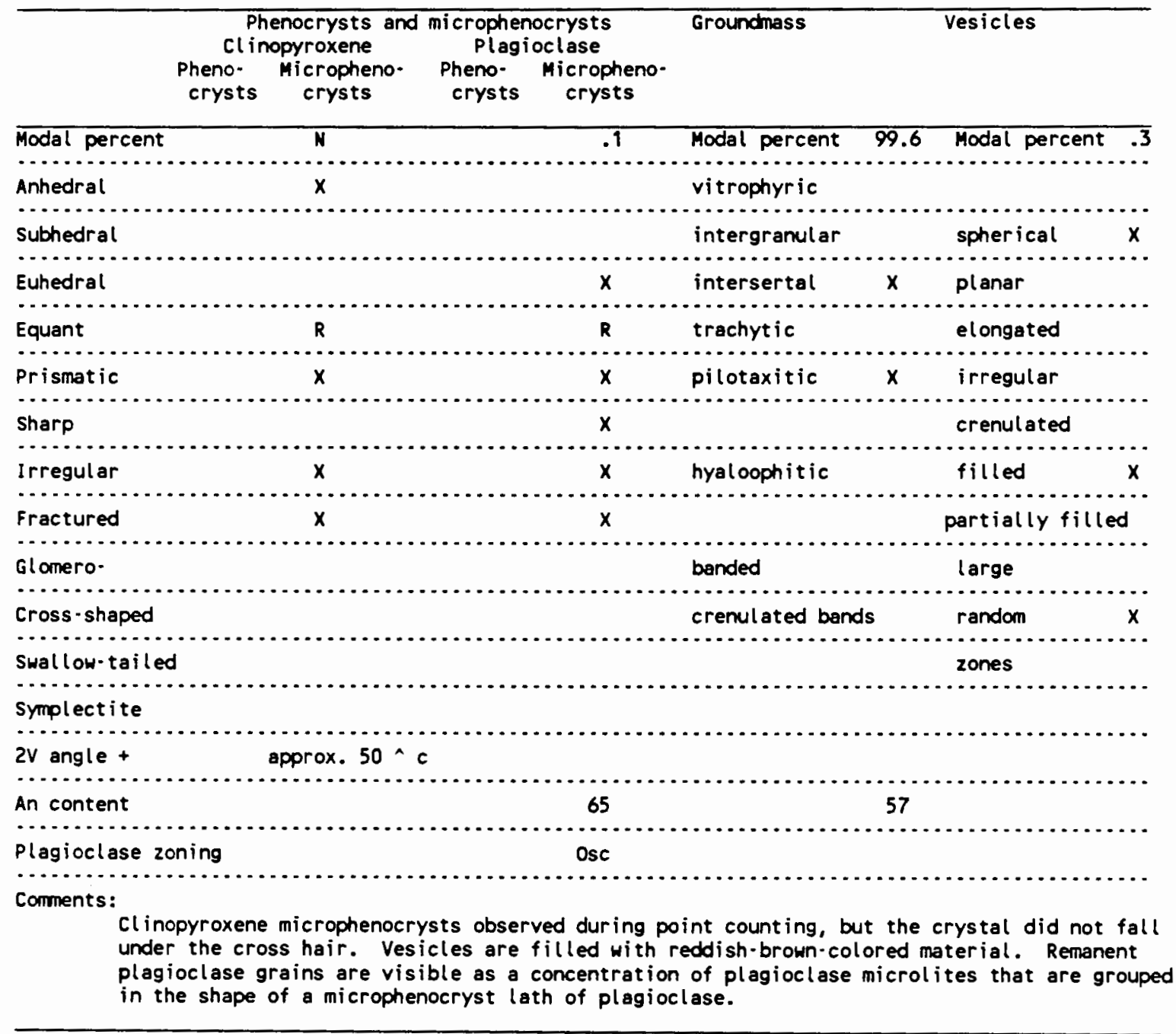


TABLE XXI

THIN SECTION DESCRIPTION FOR SAMPLE : M2

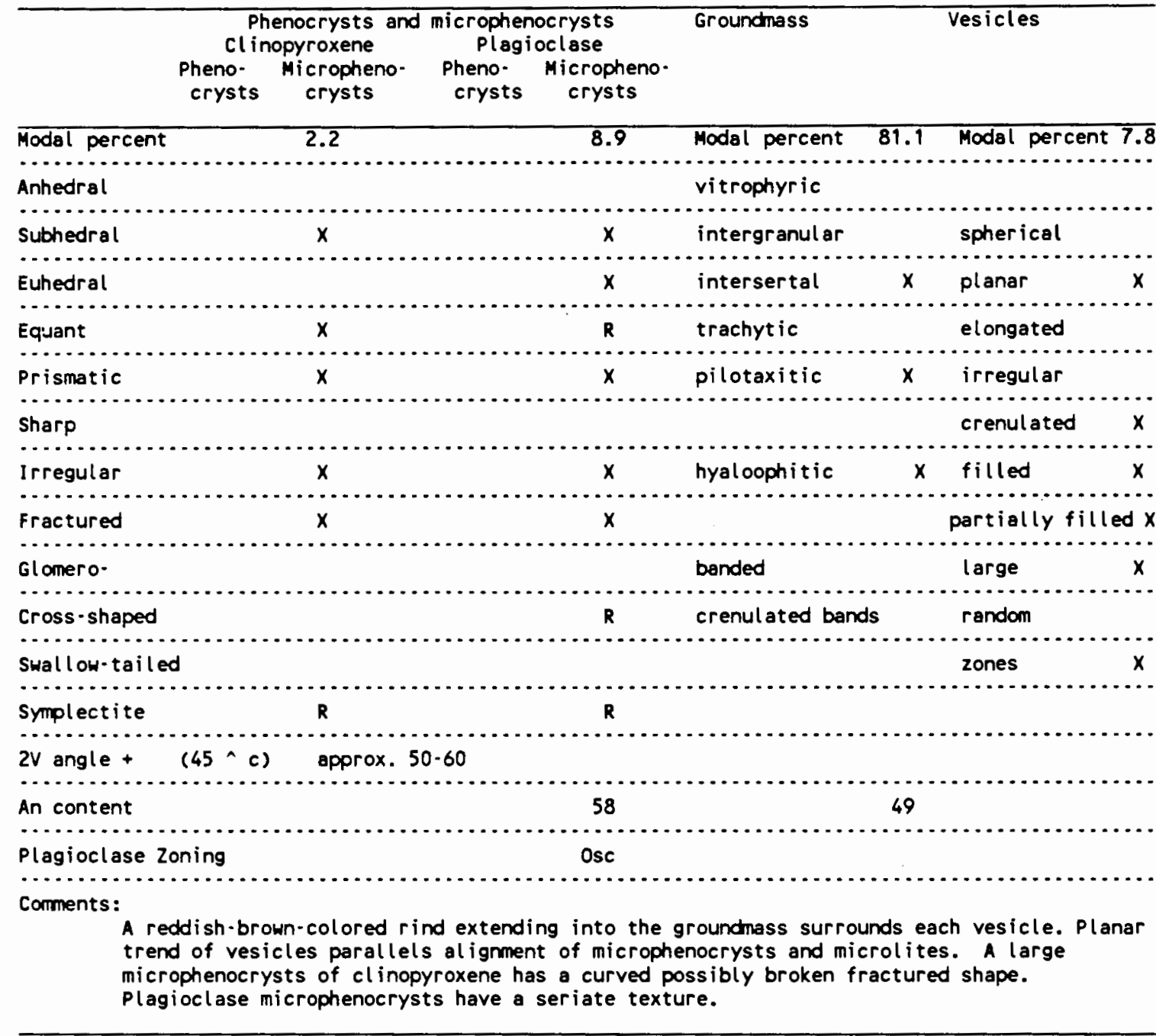


TABLE XXII

THIN SECTION DESCRIPTION FOR SAMPLE : M3

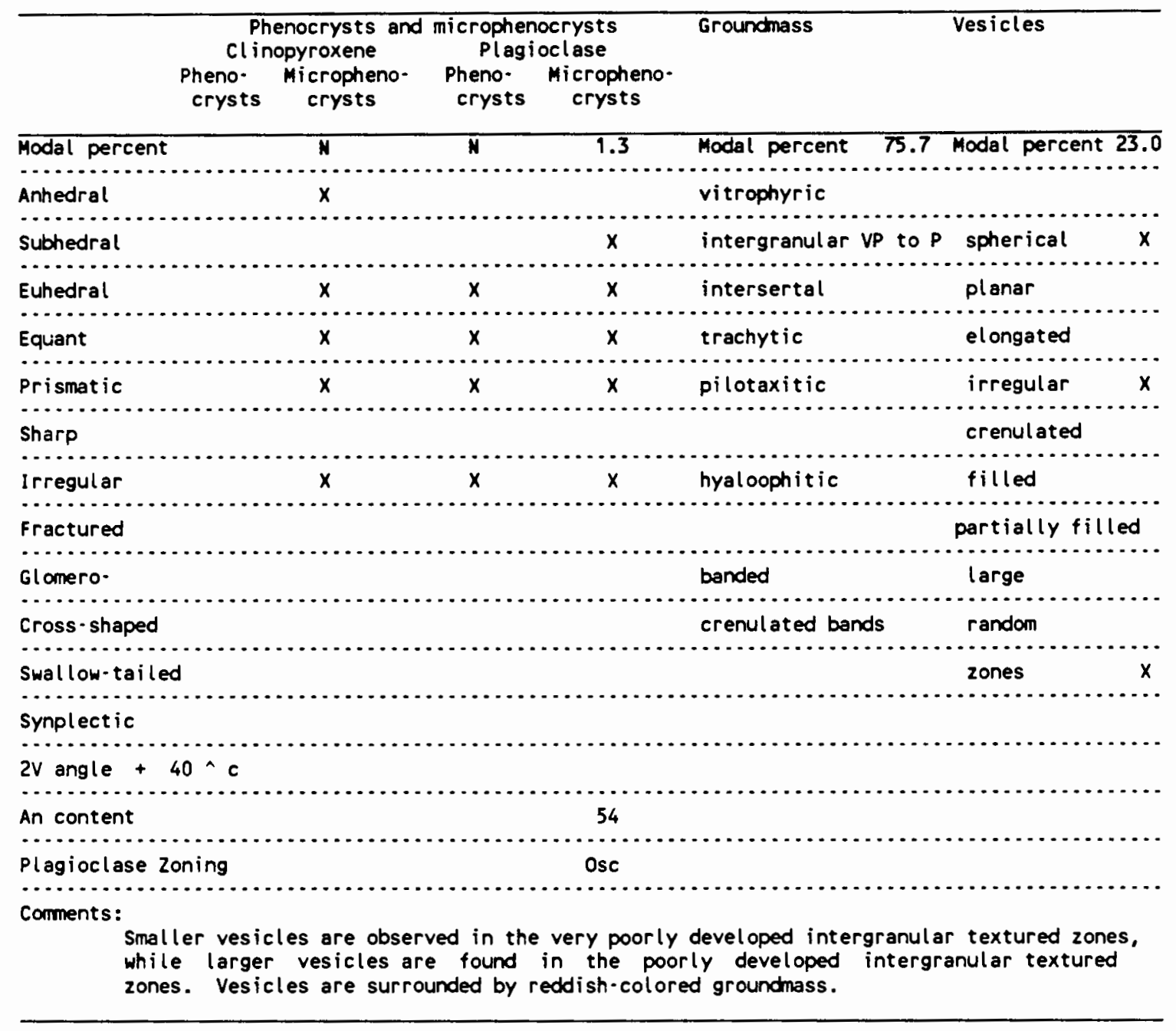


TABLE XXIV

THIN SECTION DESCRIPIION FOR SAMPLE : N

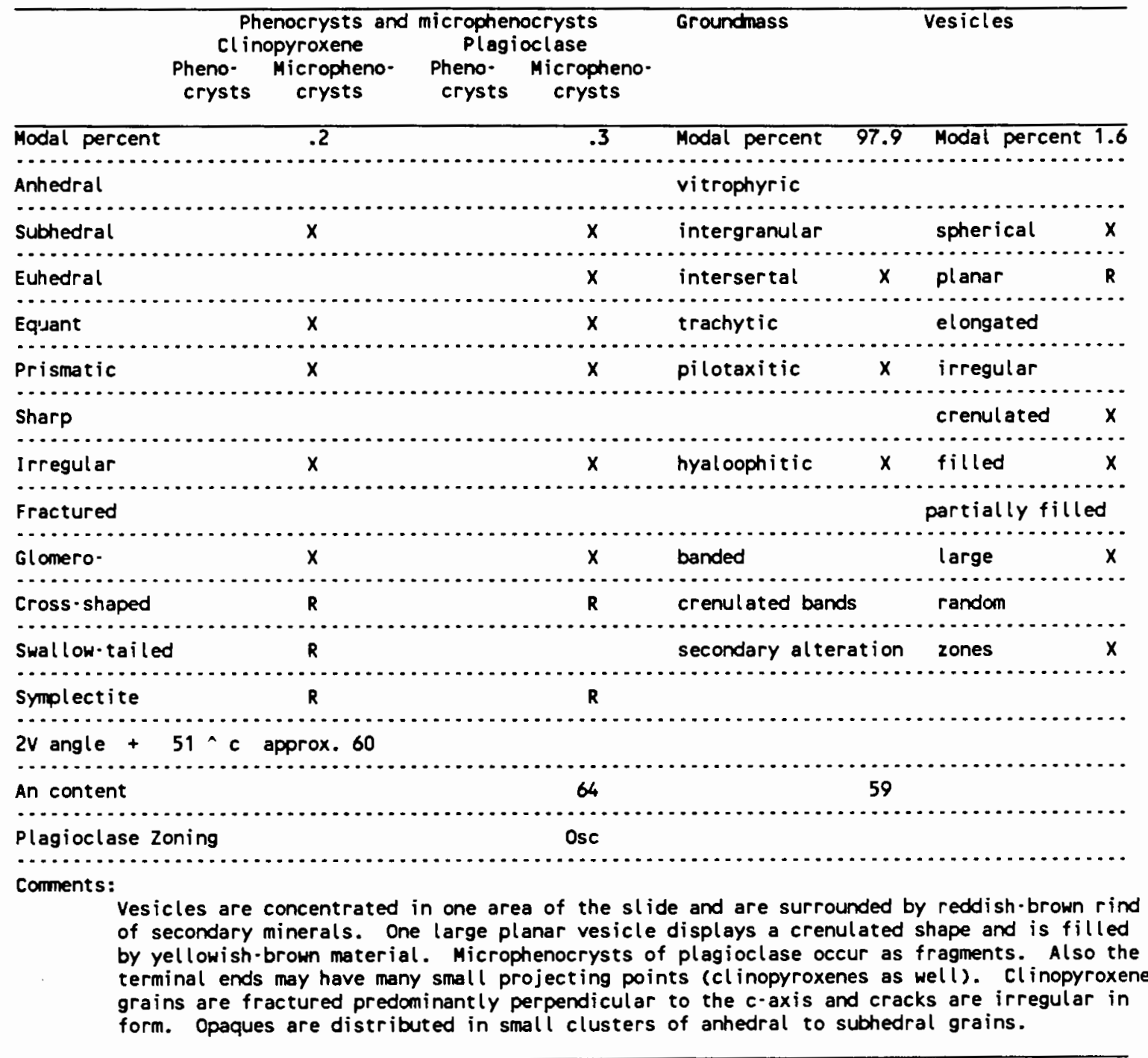


TABLE XXV

THIN SECTION DESCRIPTION FOR SAMPLE : $8-22 \# 4 C$

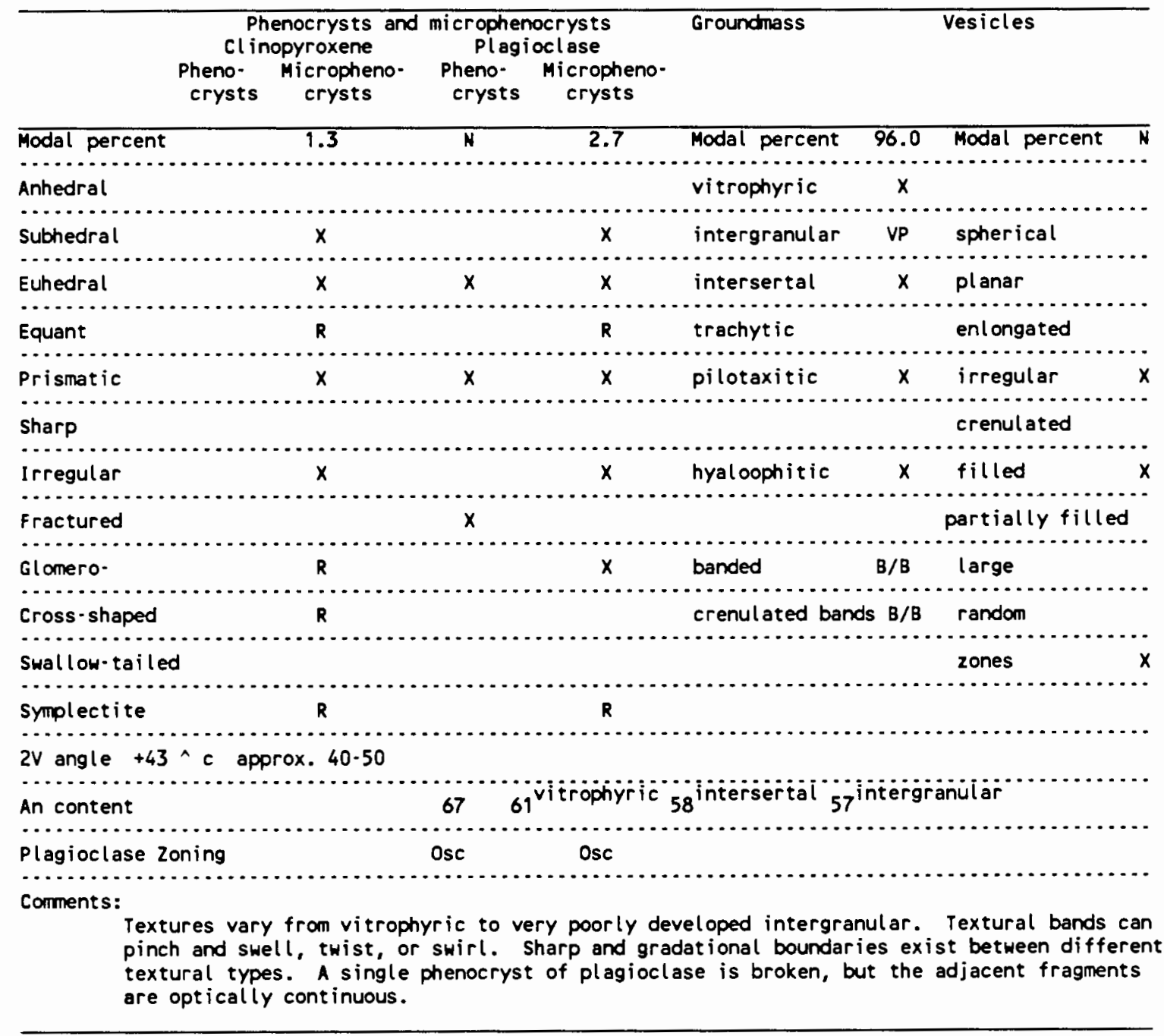


TABLE XXVI

THIN SECTION DESCRIPTION FOR SAMPLE : MC-4D

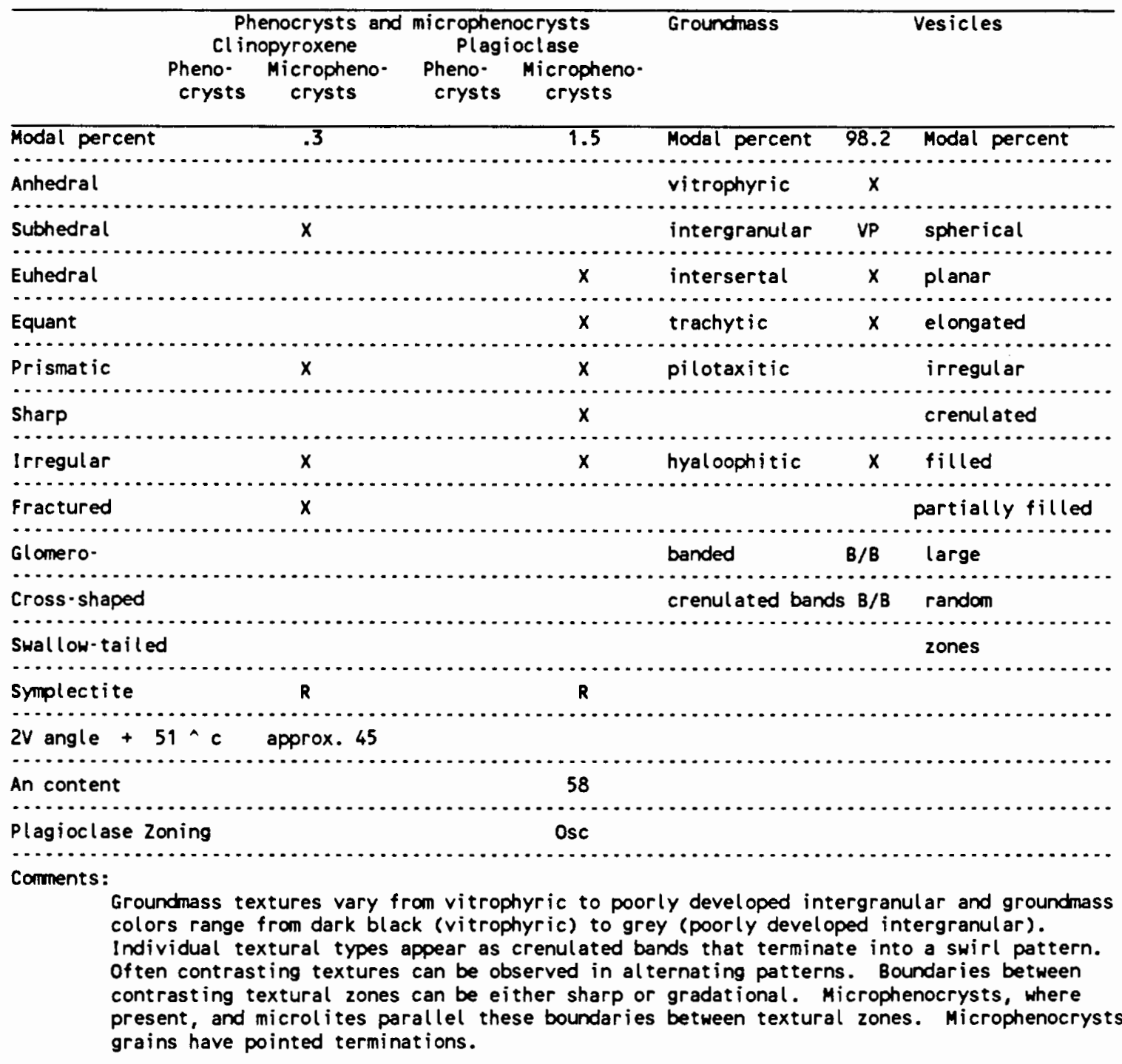


TABLE XXVII

THIN SECTION DESCRIPTION FOR SAMPLE : 8-22-T1A1

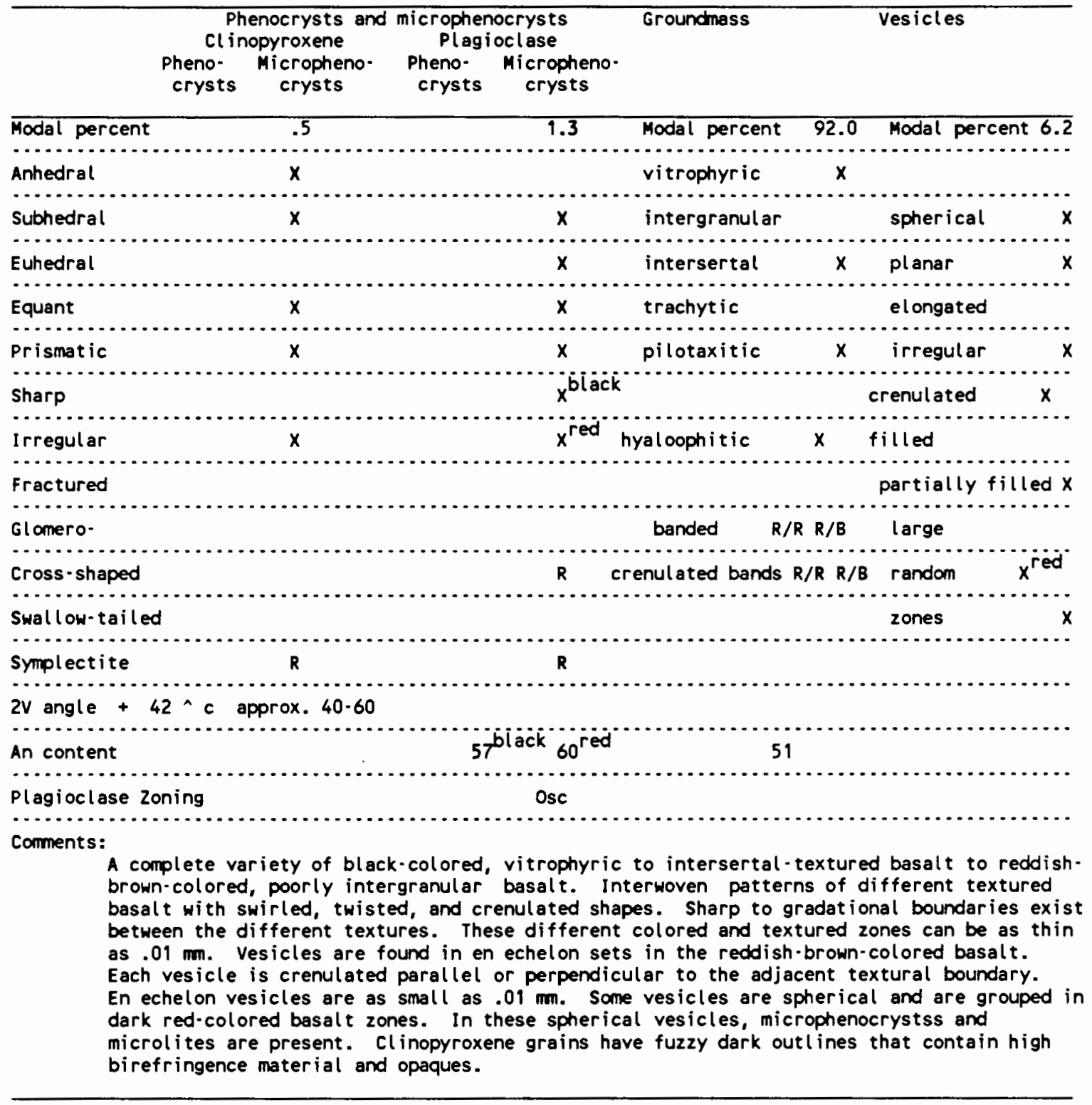


TABLE XXVIII

THIN SECTION DESCRIPTION FOR SAMPLE : 8-22-T1A2

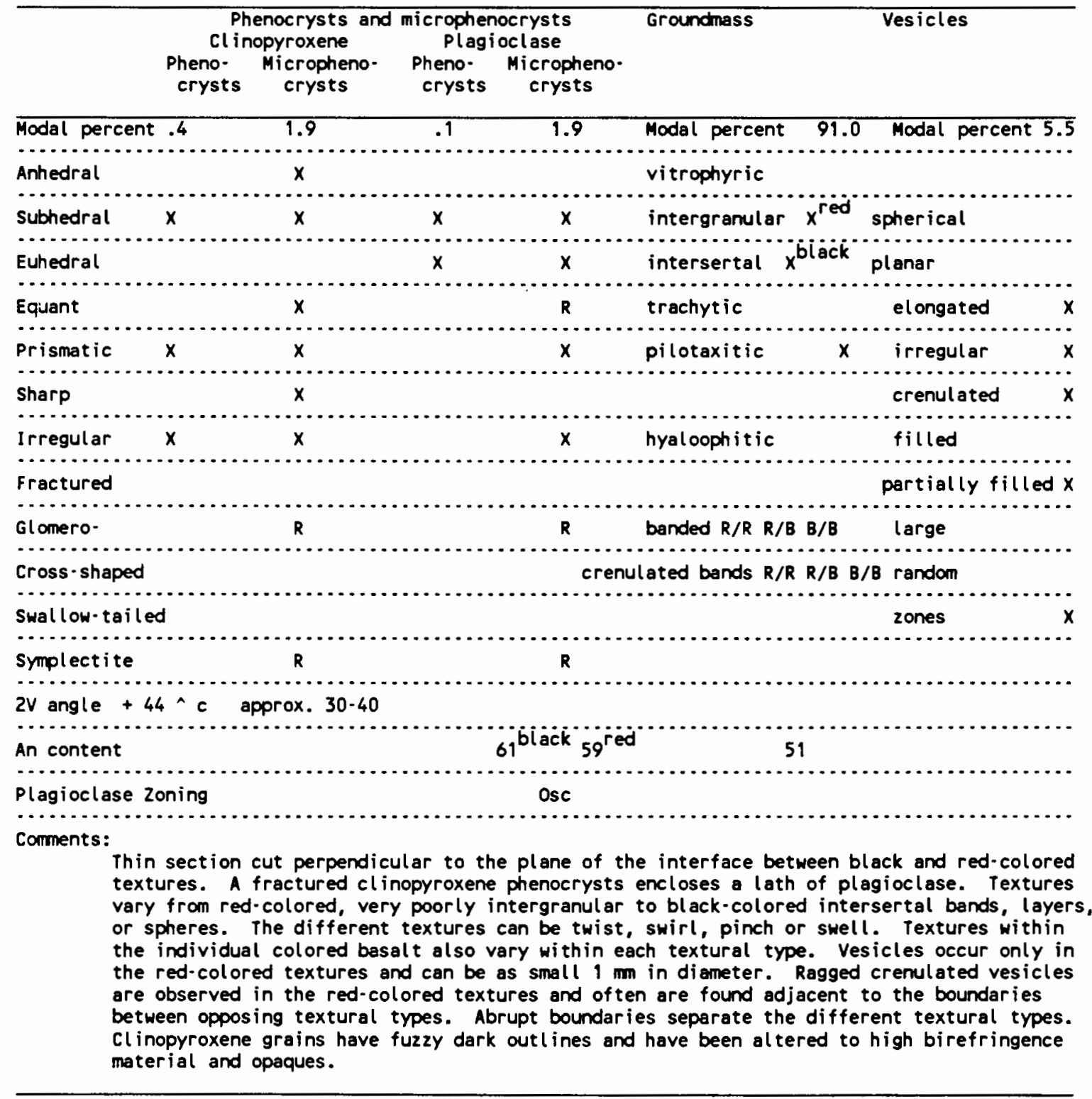


TABLE XXIX

THIN SECTION DESCRIPTION FOR SAMPLE : 8-22-T1A3

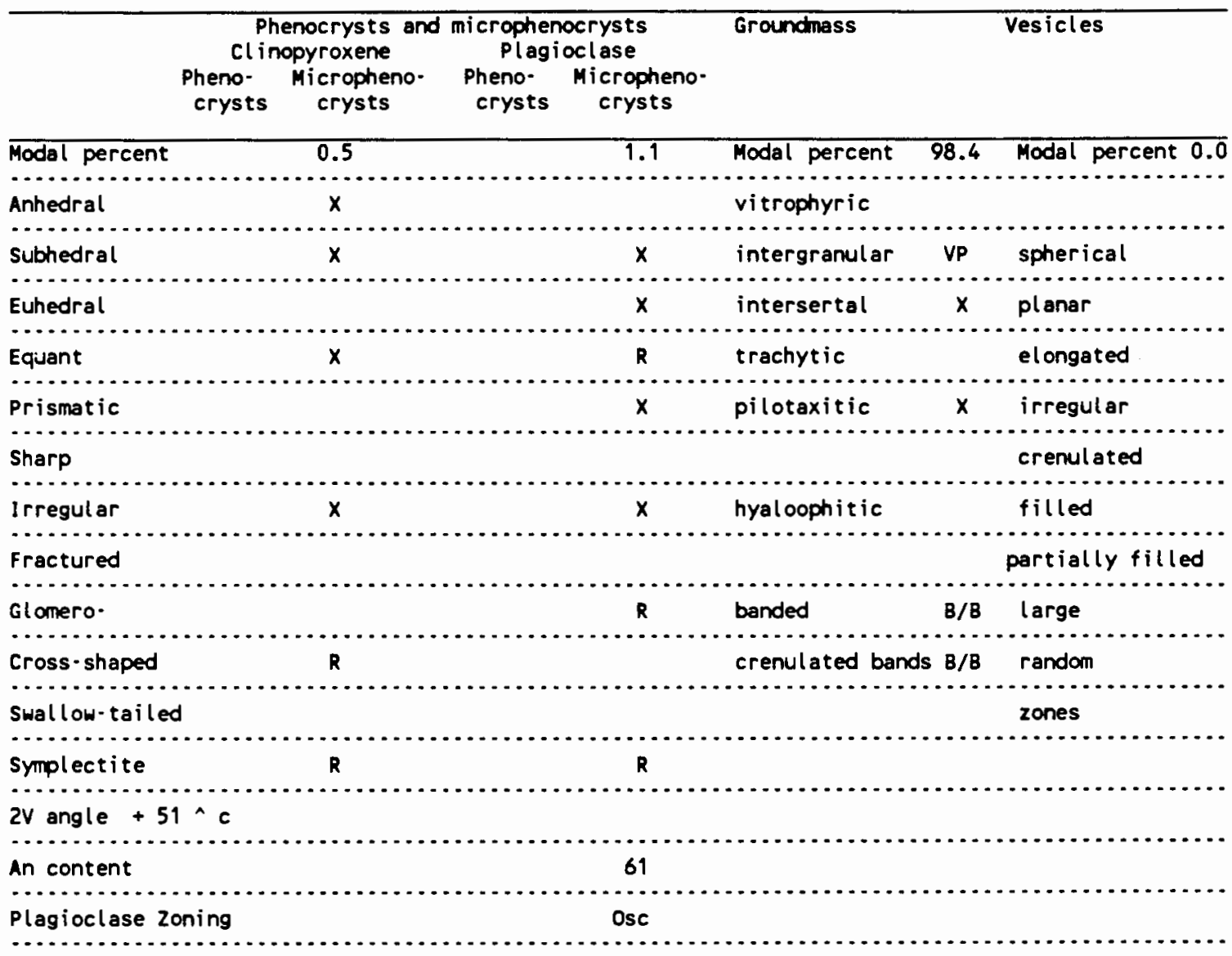

\section{Comments:}

Intercalated bands that have varying textures that are crenulated, twisted, or swirled. Textures vary from veryly poorly developed intergranular to intersertal. All textural bands or spheres are black in color. Some bands are truncated abruptly often by another set of bands at an acute angle. Some textures are observed in the form of a sphere around which the other textures pinch and swell. Microphenocrysts within the spherical textures have random orientations, while those in the adjacent bands are parallel the boundary between the textural types. 
TABLE $X X X$

THIN SECTION DESCRIPTION FOR SAMPLE : 8-22-T1B

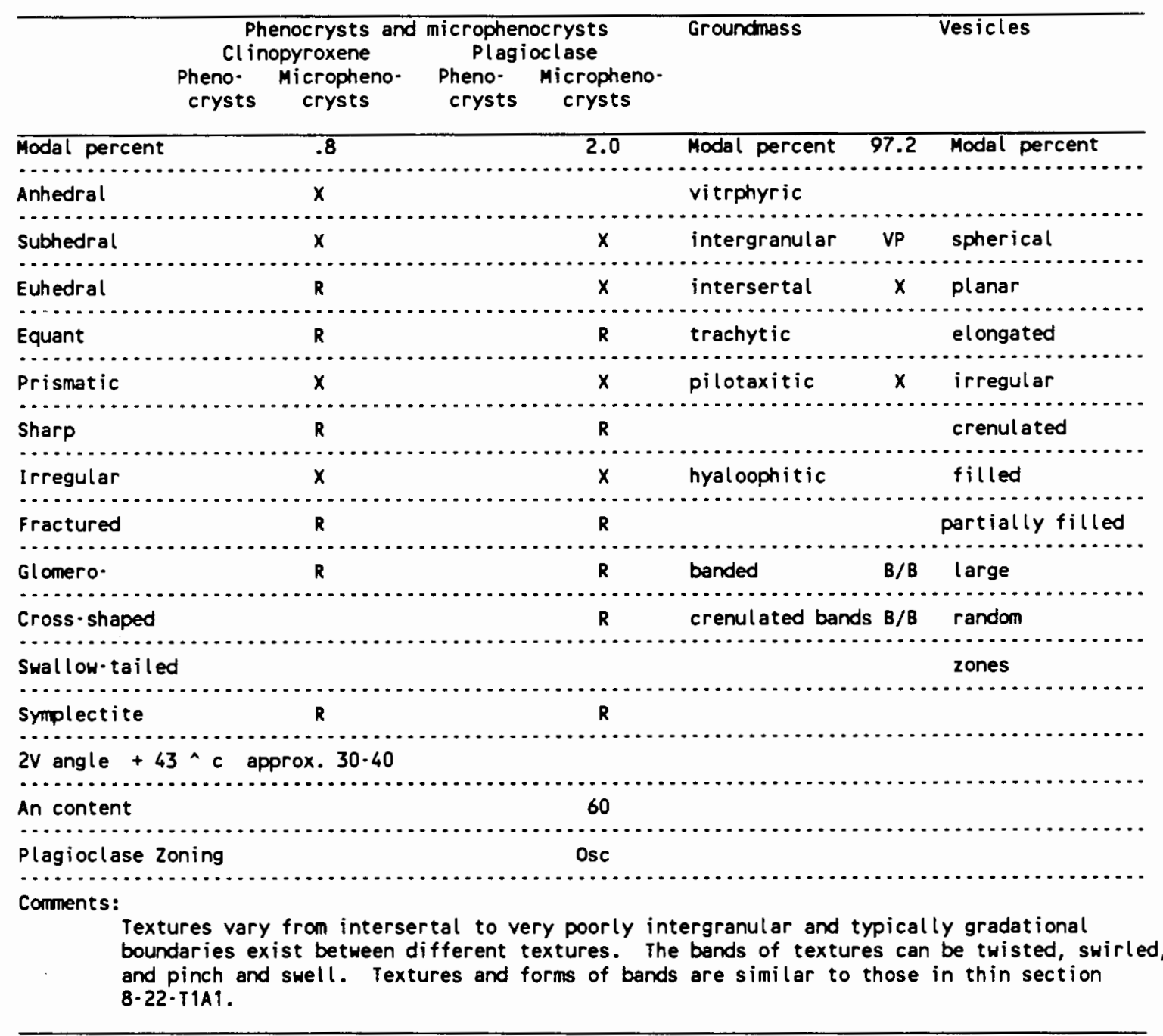


TABLE XXXI

THIN SECTION DESCRIPTION FOR SAMPLE : 8-22-T1C

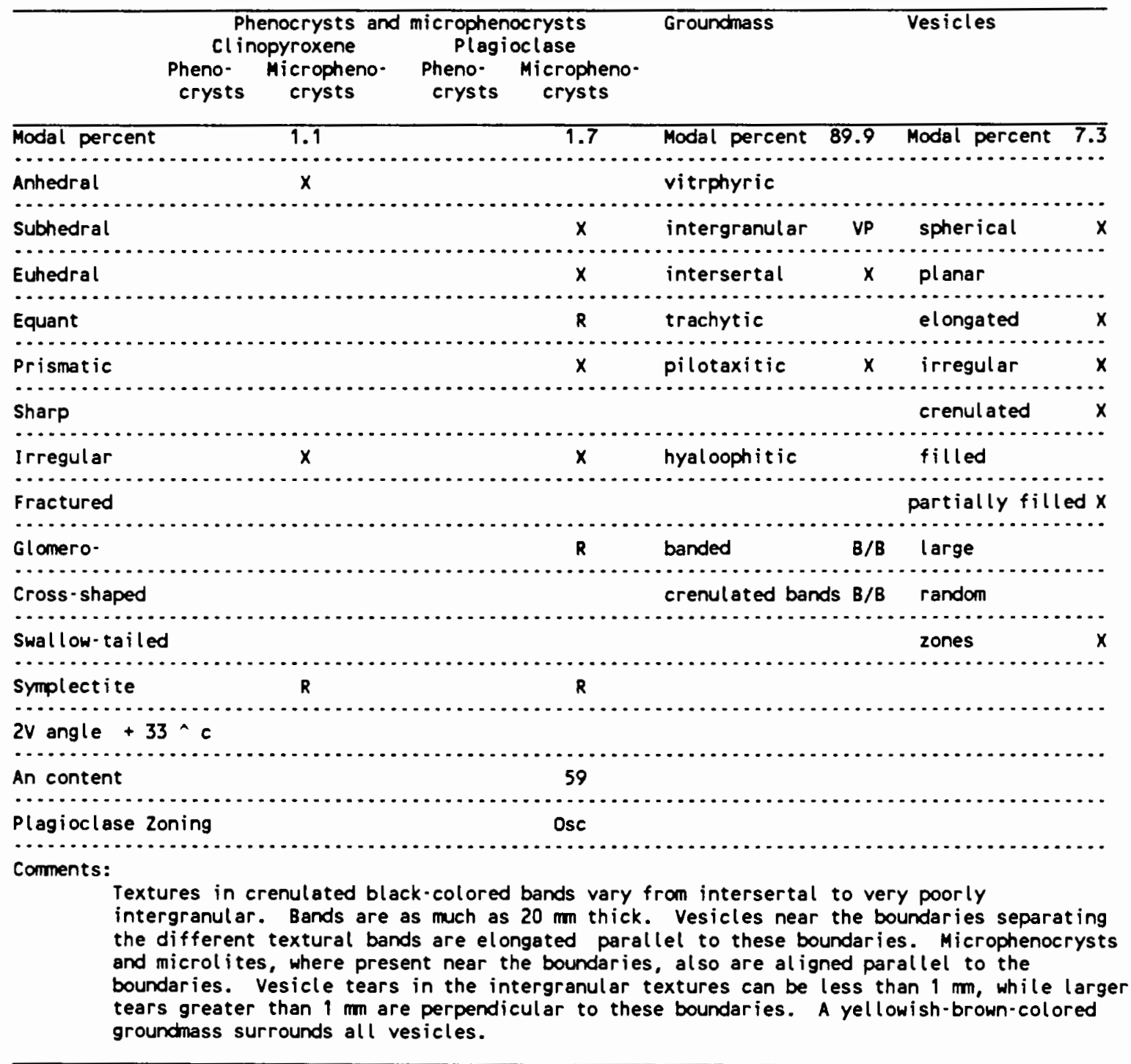


TABLE XXXII

THIN SECTION DESCRIPTION FOR SAMPLE : 8-22-SC\#1

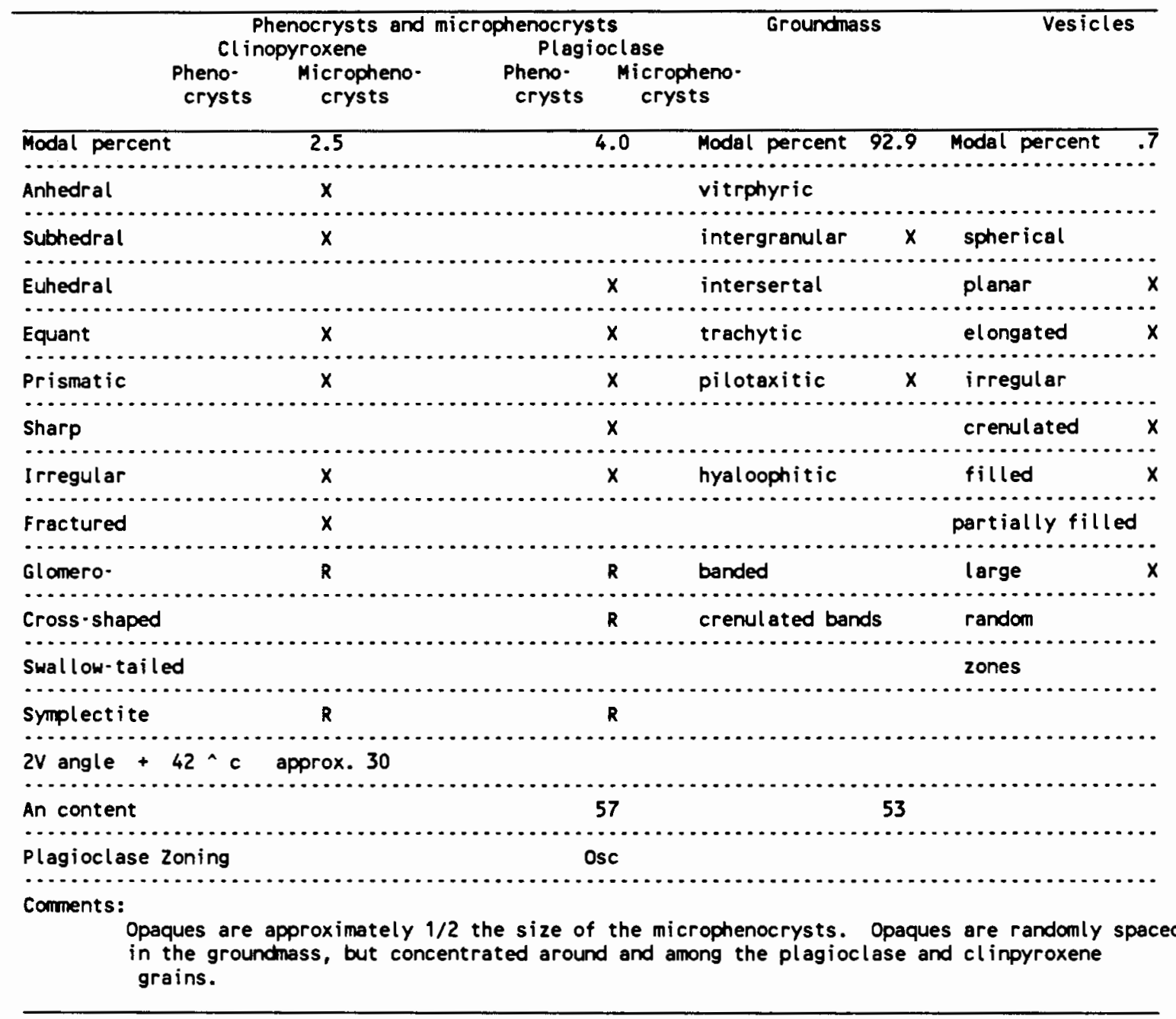


TABLE $X \times \times 111$

THIN SECTION DESCRIPTION FOR SAMPLE : 8-22-SC\$2

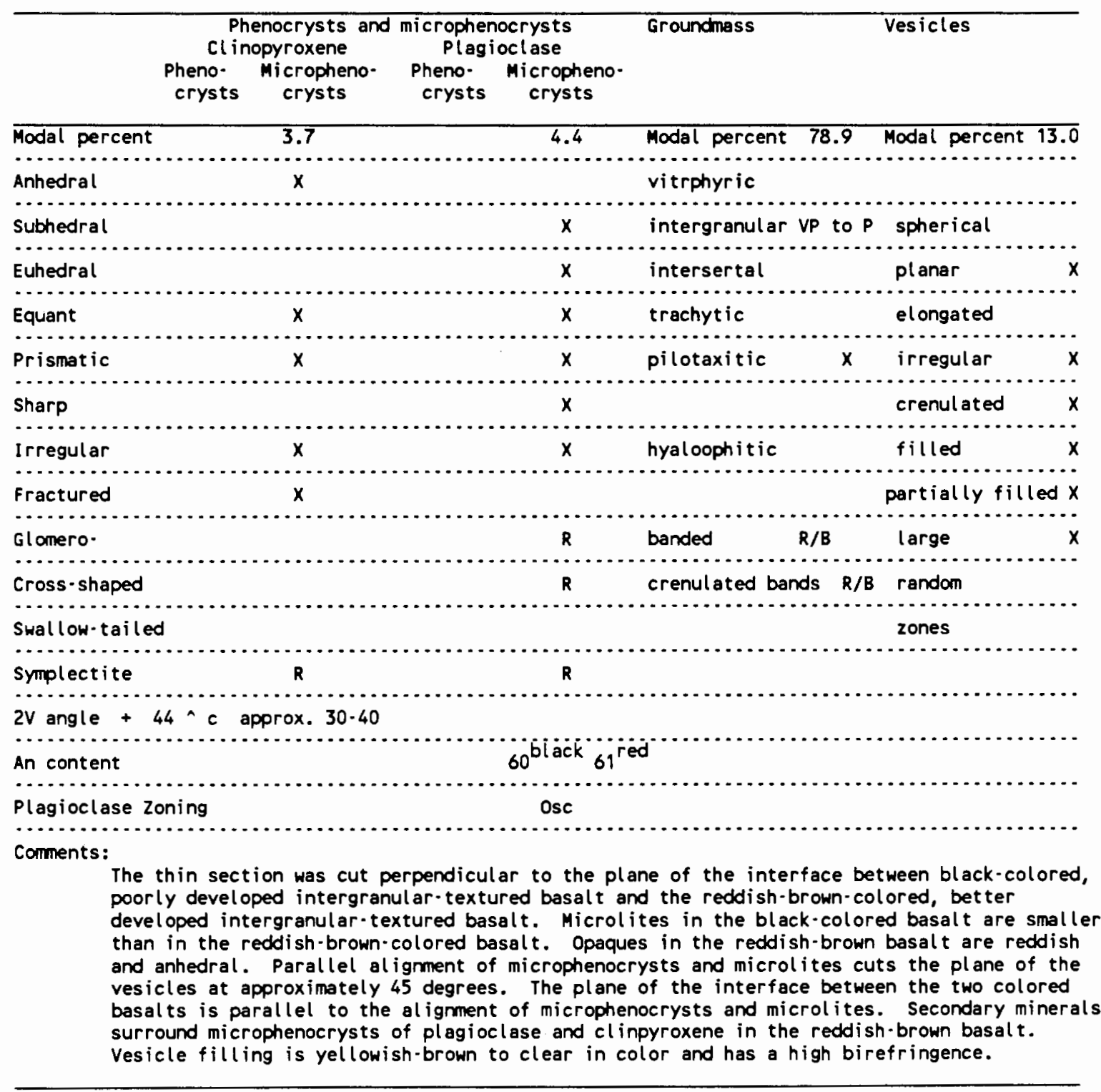


TABLE XXIV

THIN SECTION DESCRIPTION FOR SAMPLE : 8-22-SC\#3

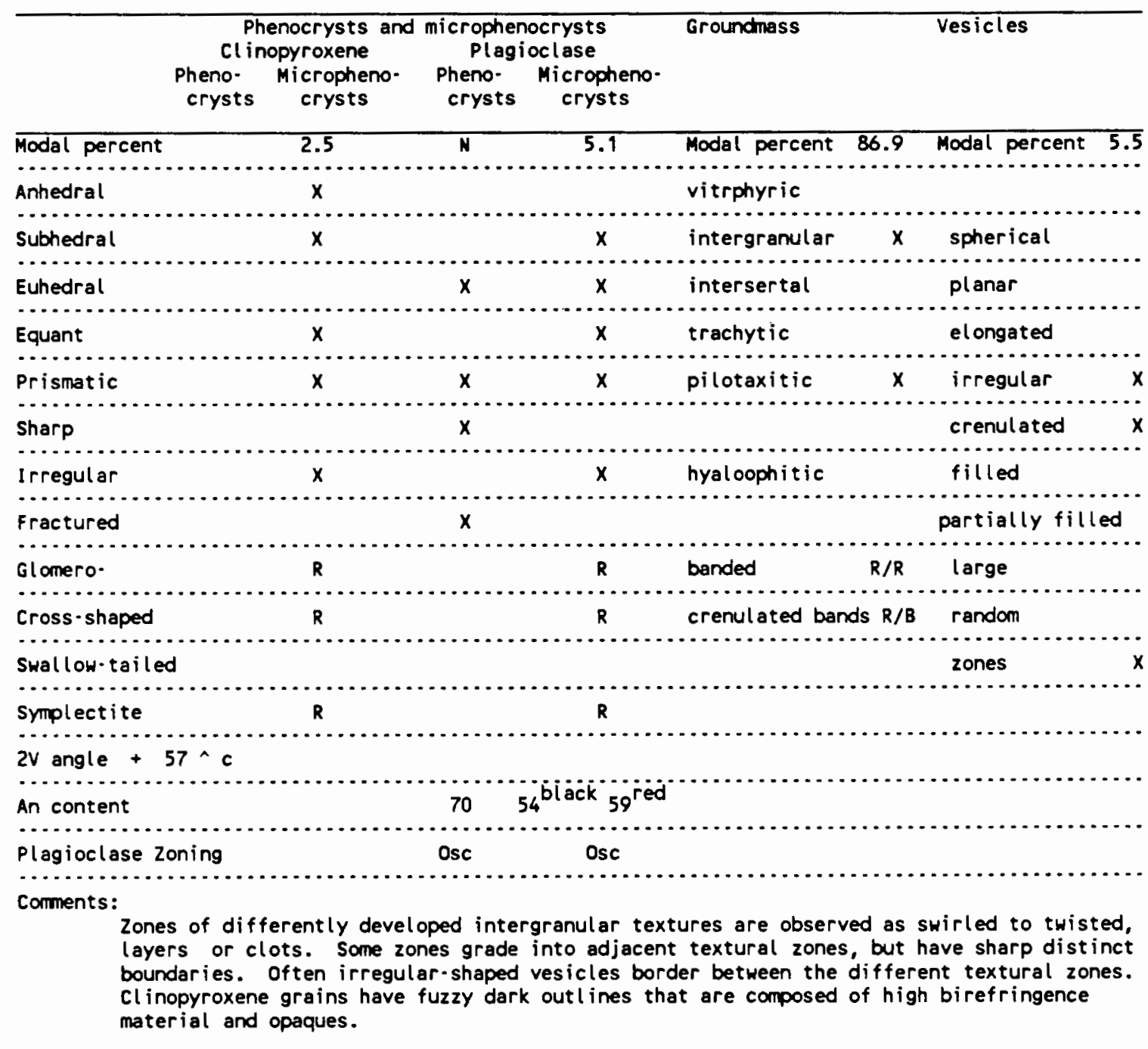


TABLE XXXV

THIN SECTION DESCRIPTION FOR SAMPLE : $8 \cdot 21 \$ 3 B$

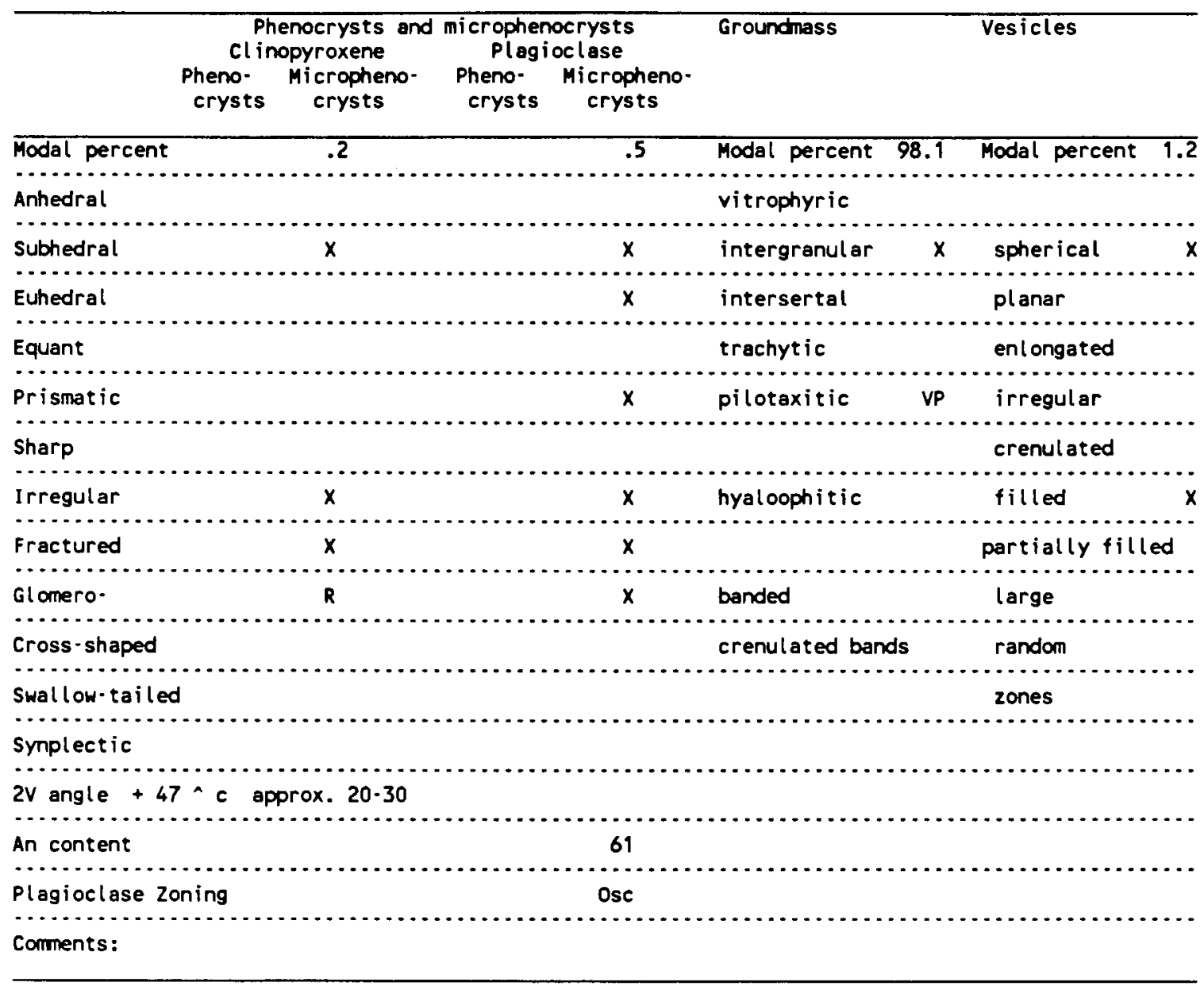


TABLE XXXVI

THIN SECTION DESCRIPTION FOR SAMPLE : $8-21 \# 4 B$

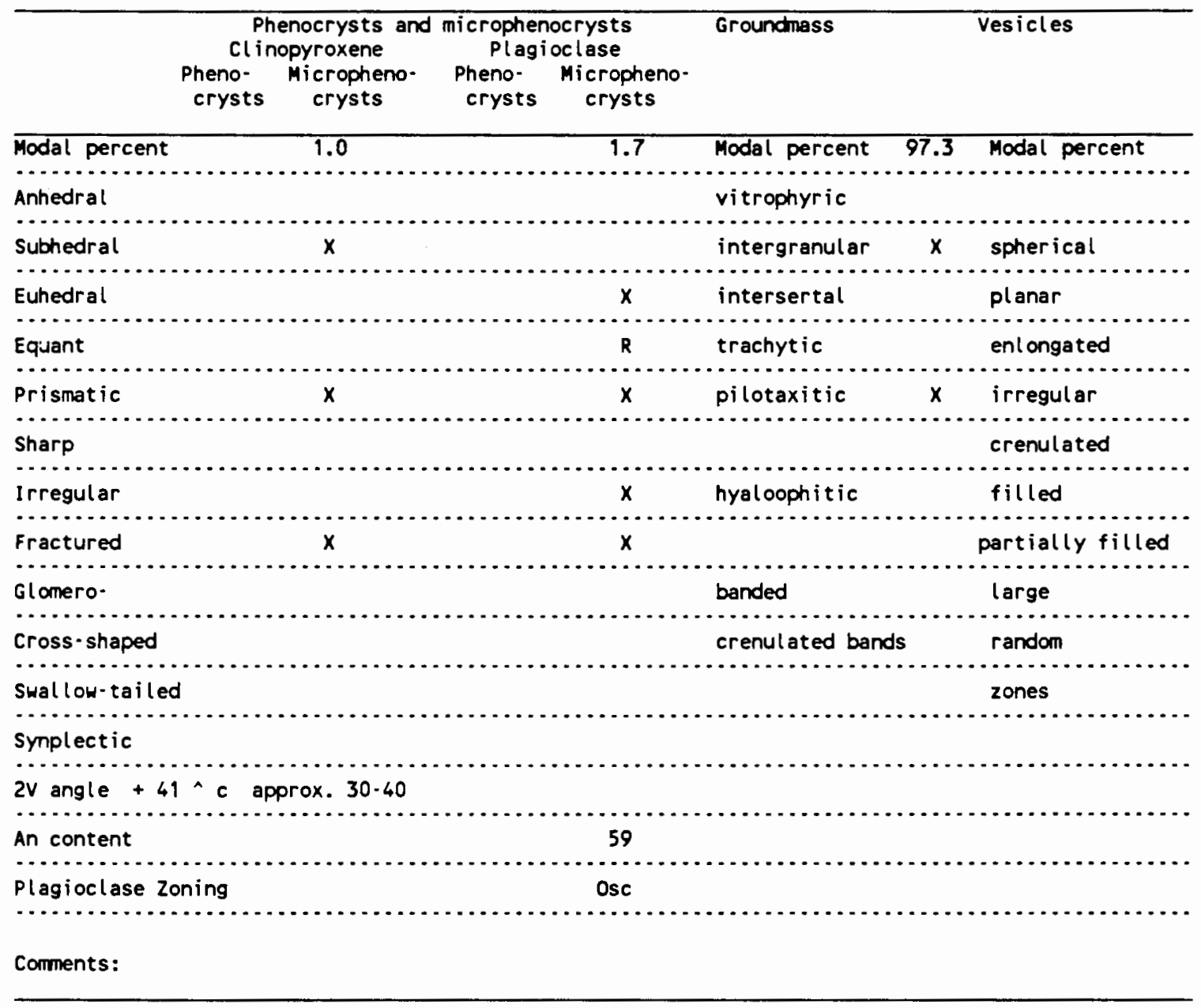


TABLE XXXYII

THIN SECTION DESCRIPTION FOR SAMPLE : $8-20 \# 2$

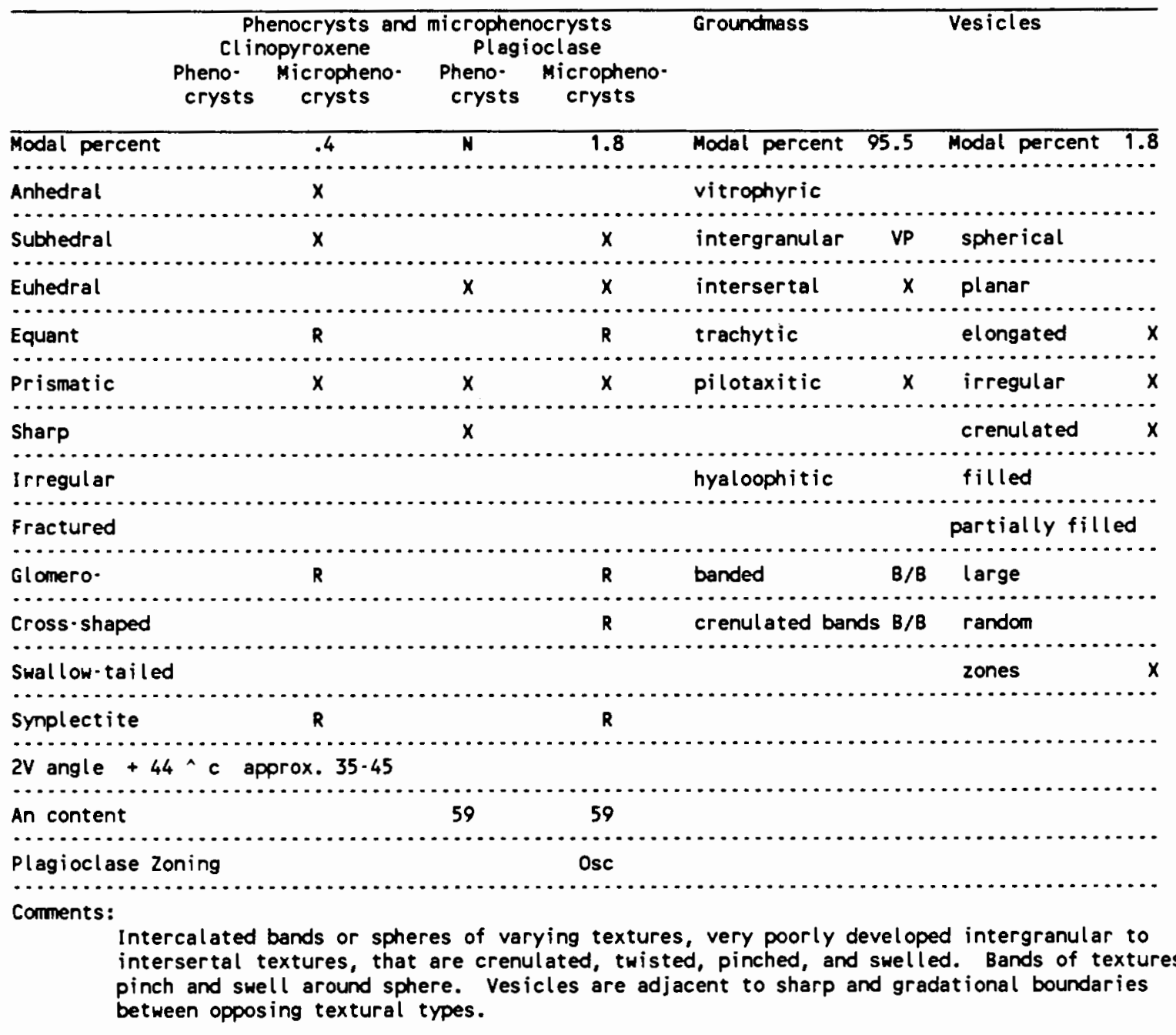


TABLE XXXVIII

THIN SECTION DESCRIPTION FOR SAMPLE : $8-20 \# 3$

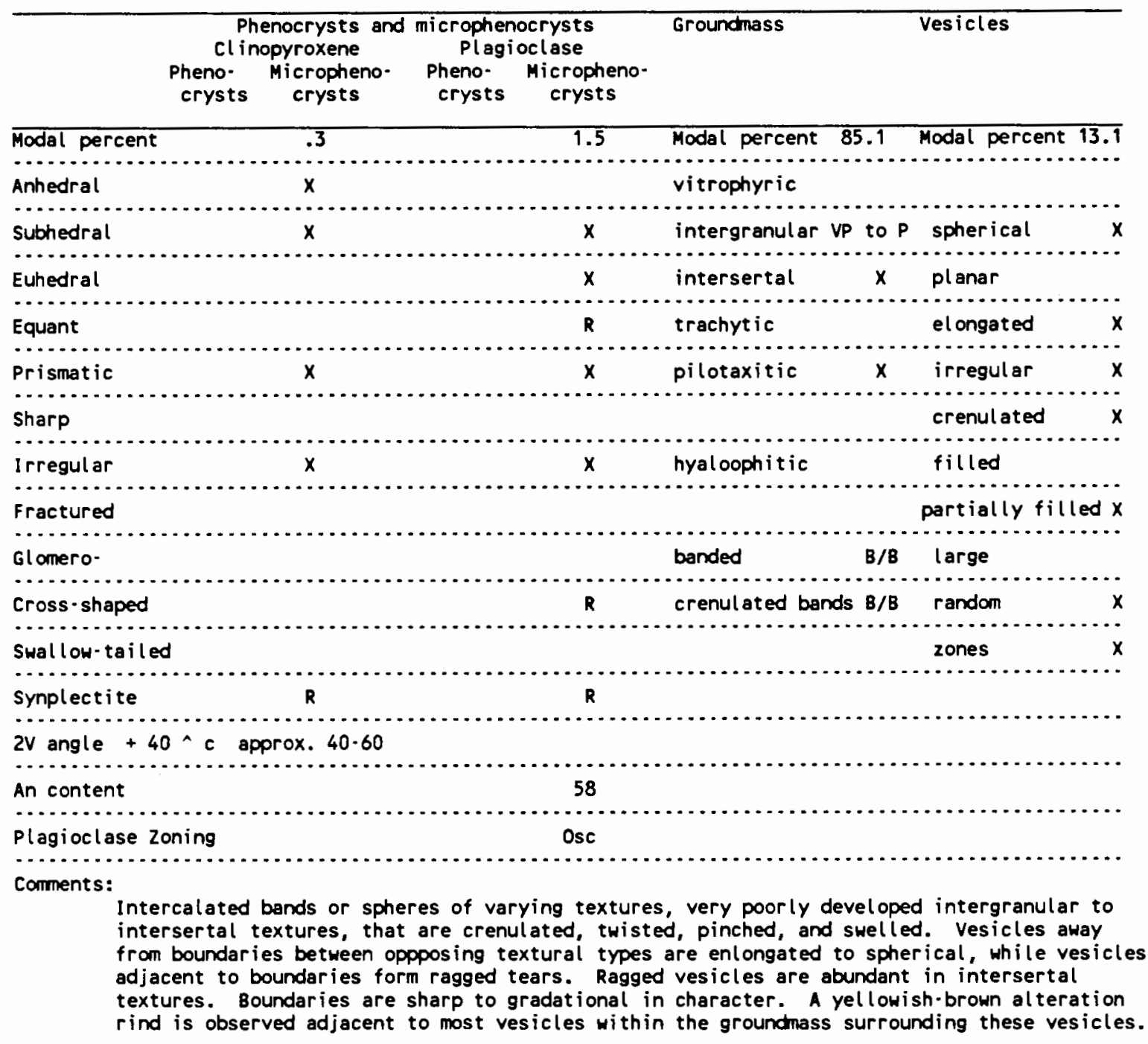


TABLE XXXIX

THIN SECTION DESCRIPTION FOR SAMPLE : $8-20 \# 4$

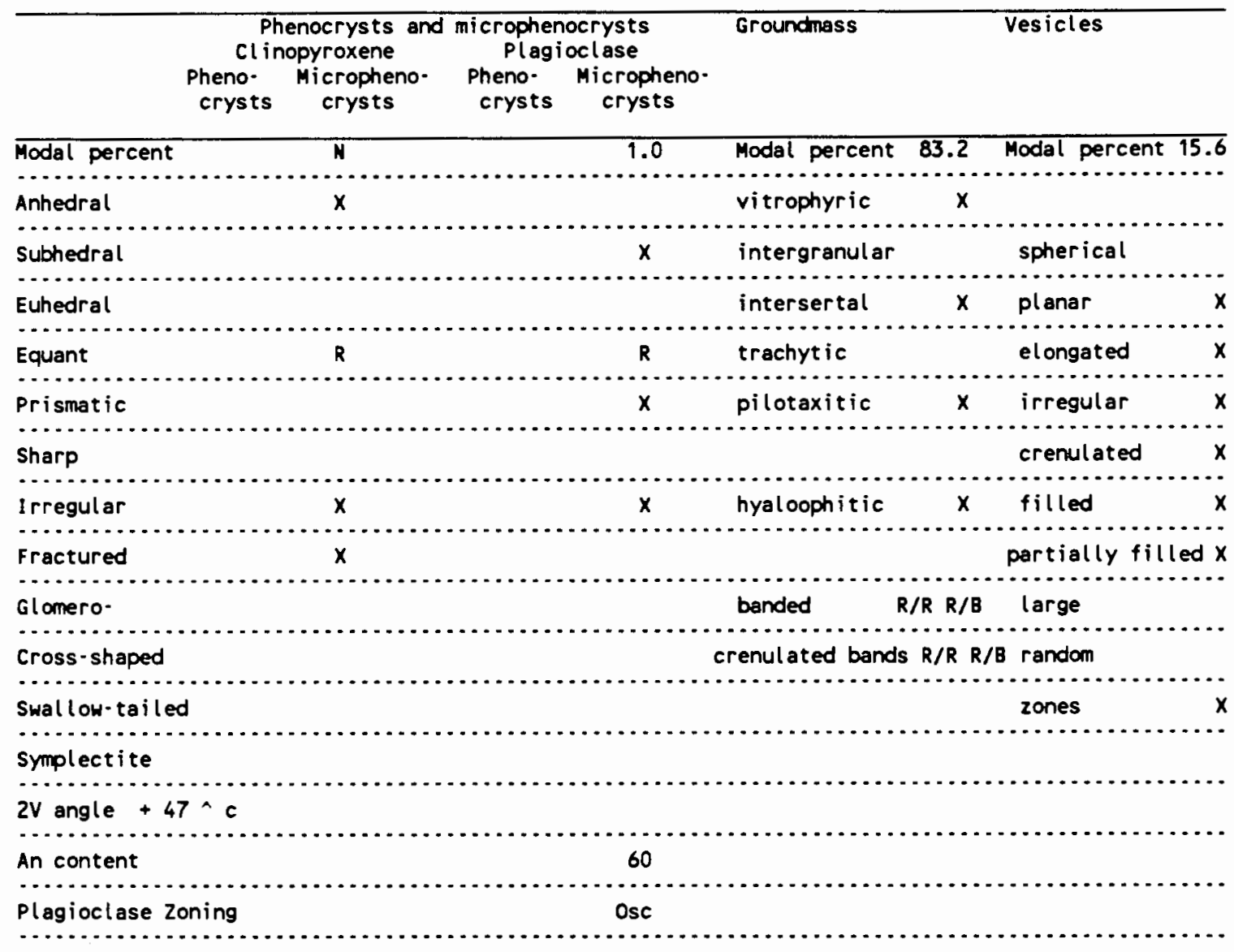

\section{Comments:}

Intercalated bands or spheres of varying textures that vary from intersertal to vitrophyric. Bands are crenulated, twisted, pinched and swelled, or swirled. Textural bands are colored from red for intersertal textures to black for vitrophyric basalt. Vesicular tears are concentrated in the red colored intersertal basalt. Vesicles are interlocked and are extremely ragged in appearances. Boundaries between opposing textures are abrupt. In the one area where vesicles tears are abundant, individual clasts are interwoven with one another in the center of a band. Rare clasts are broken into fragments. Vesicles are partly filled with a high birefringence material. The peripheral margins of this clastfilled band have small vesicle tears parallel to the adjacent boundaries of vitrophyric textures. This clast-filled band pinches and swell. Clast sizes range from $2 \mathrm{~mm}$ in diameter to $.5 \mathrm{~mm}$. Clast types vary from vesicular to nonvesicular basalt that are colored either black or organish-red. Larger vesicle tears occur in the vitrophyric bands. 
TABLE XL

THIN SECTION DESCRIPTION FOR SAMPLE : 8-20\#5

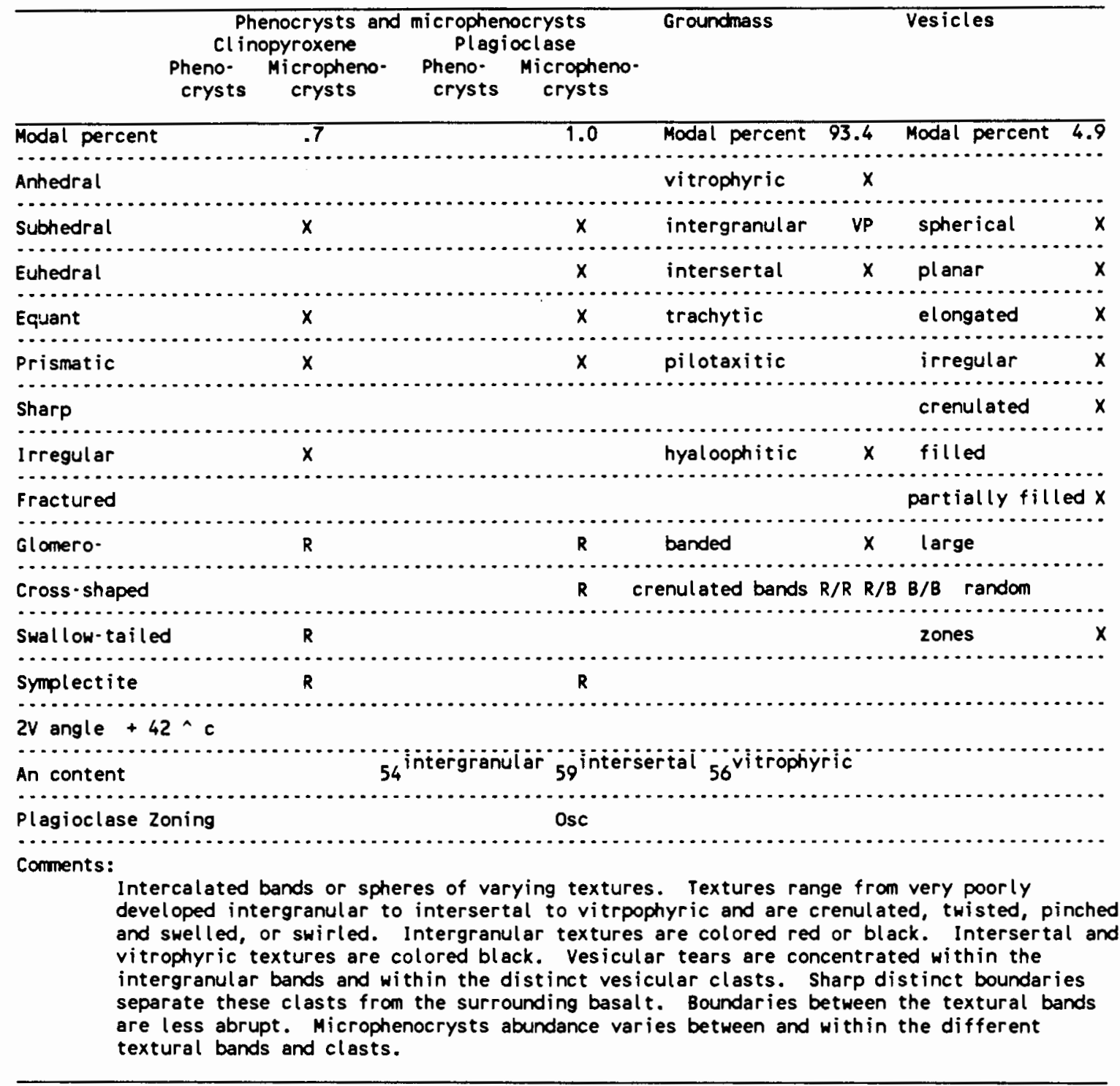


TABLE XLI

THIN SECTION OESCRIPTION FOR SAMPLE : 8-21\#2A

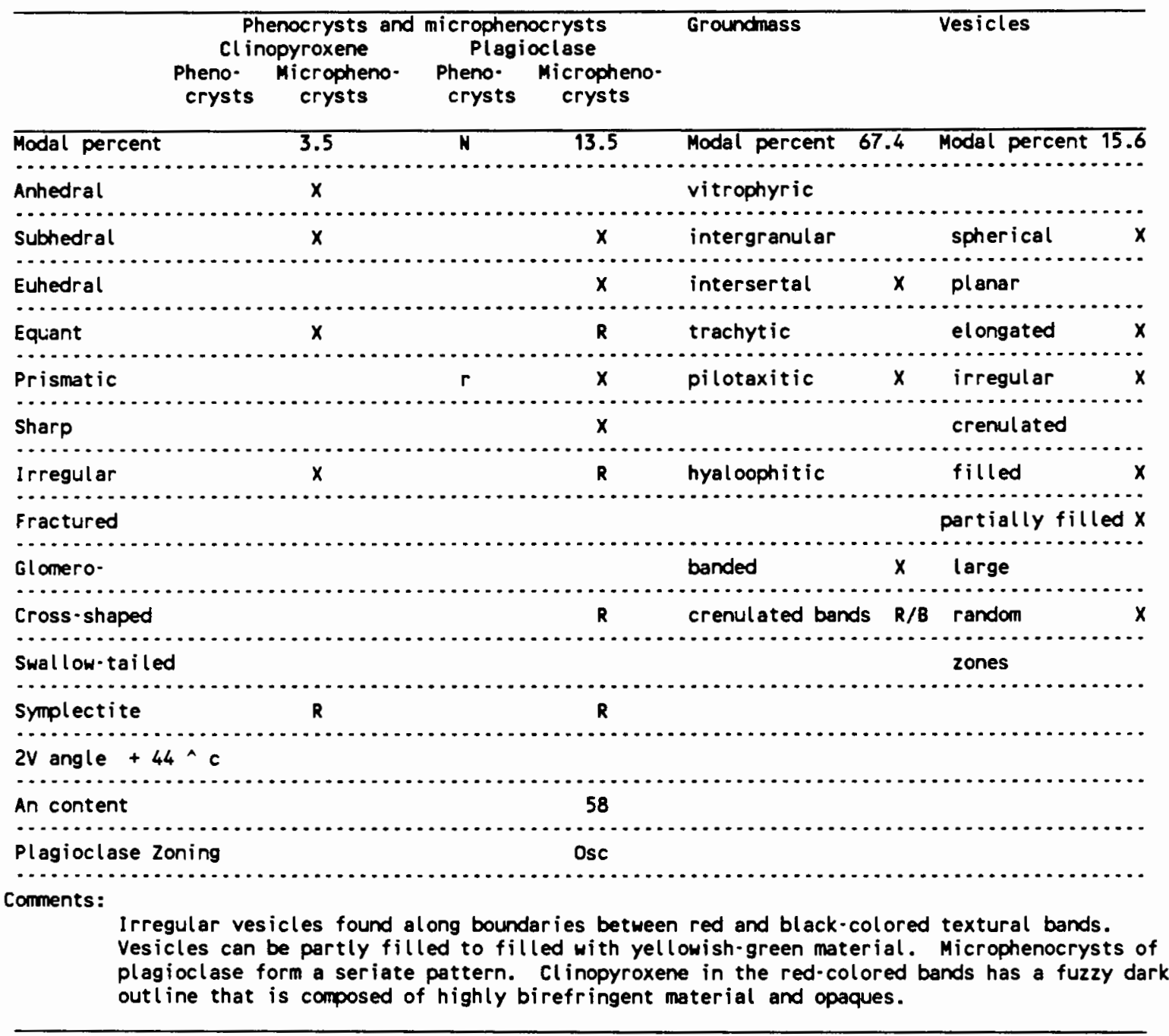


TABLE XLII

THIN SECTION DESCRIPTION FOR SAMPLE : $8 \cdot 21 \$ 3 A$

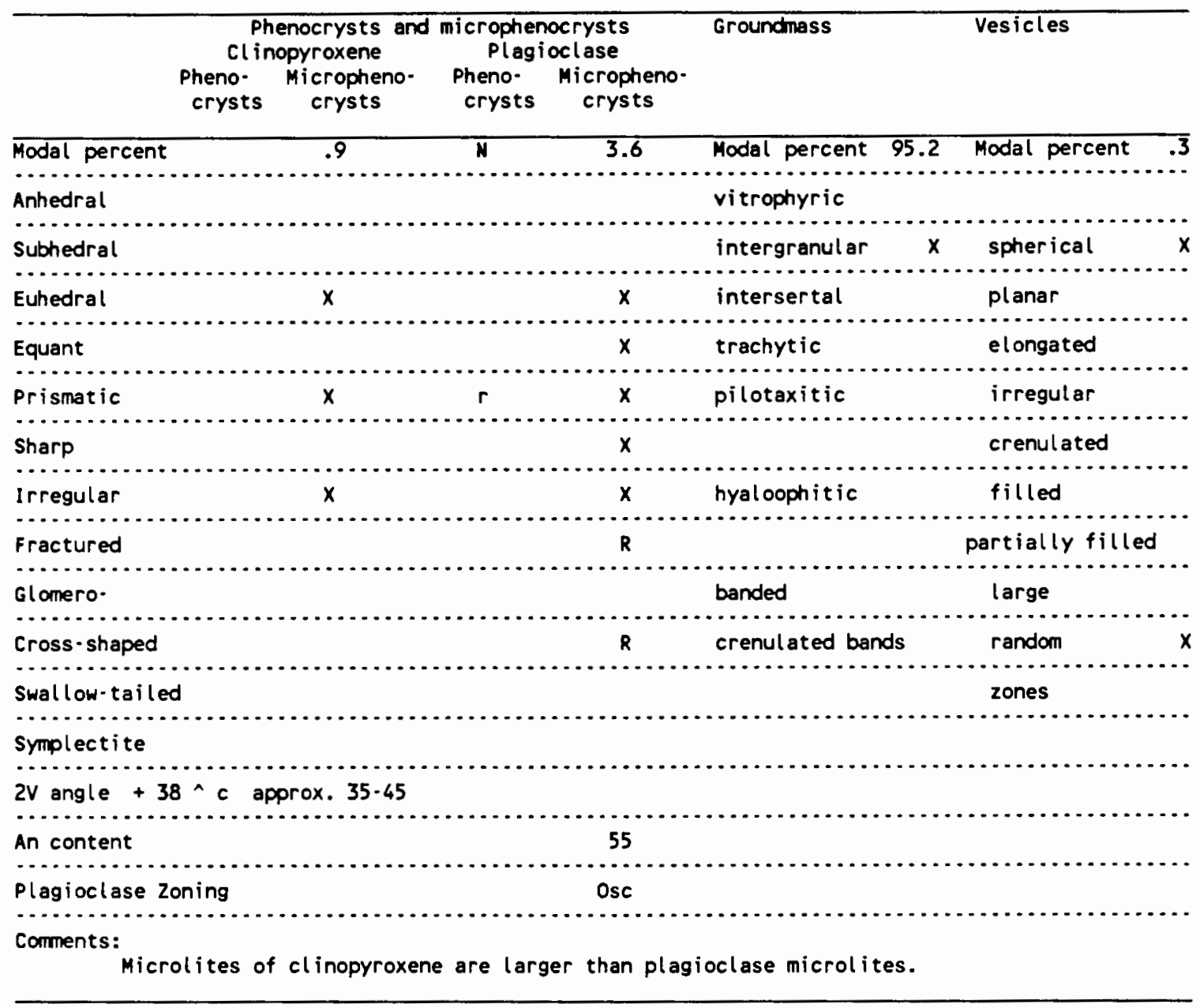


TABLE XLI II

THIN SECTION DESCRIPTION FOR SAMPLE : 8-21\#5A

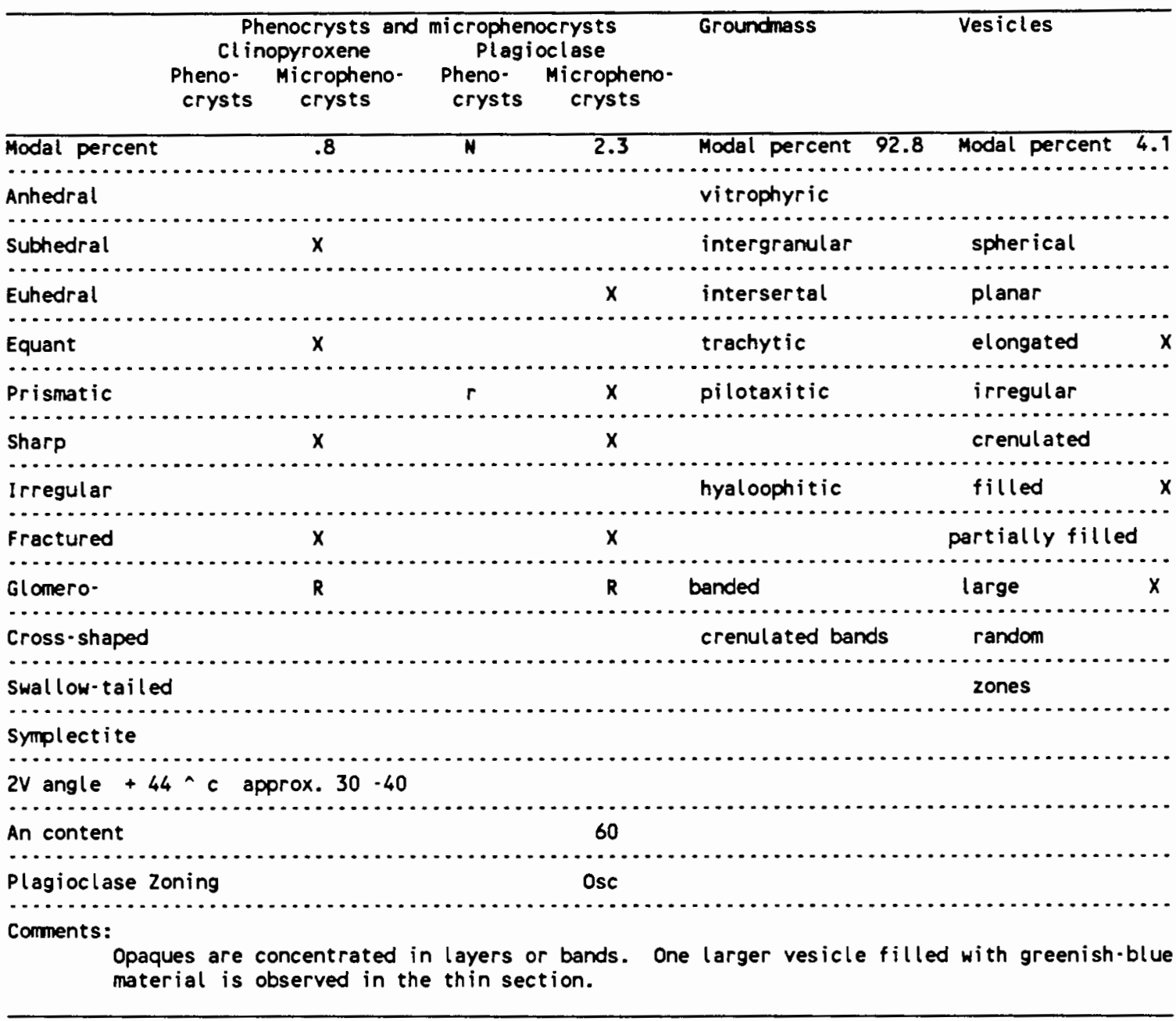


TABLE XLIV

THIN SECTION DESCRIPTION FOR SAMPLE : 8-21\#7A

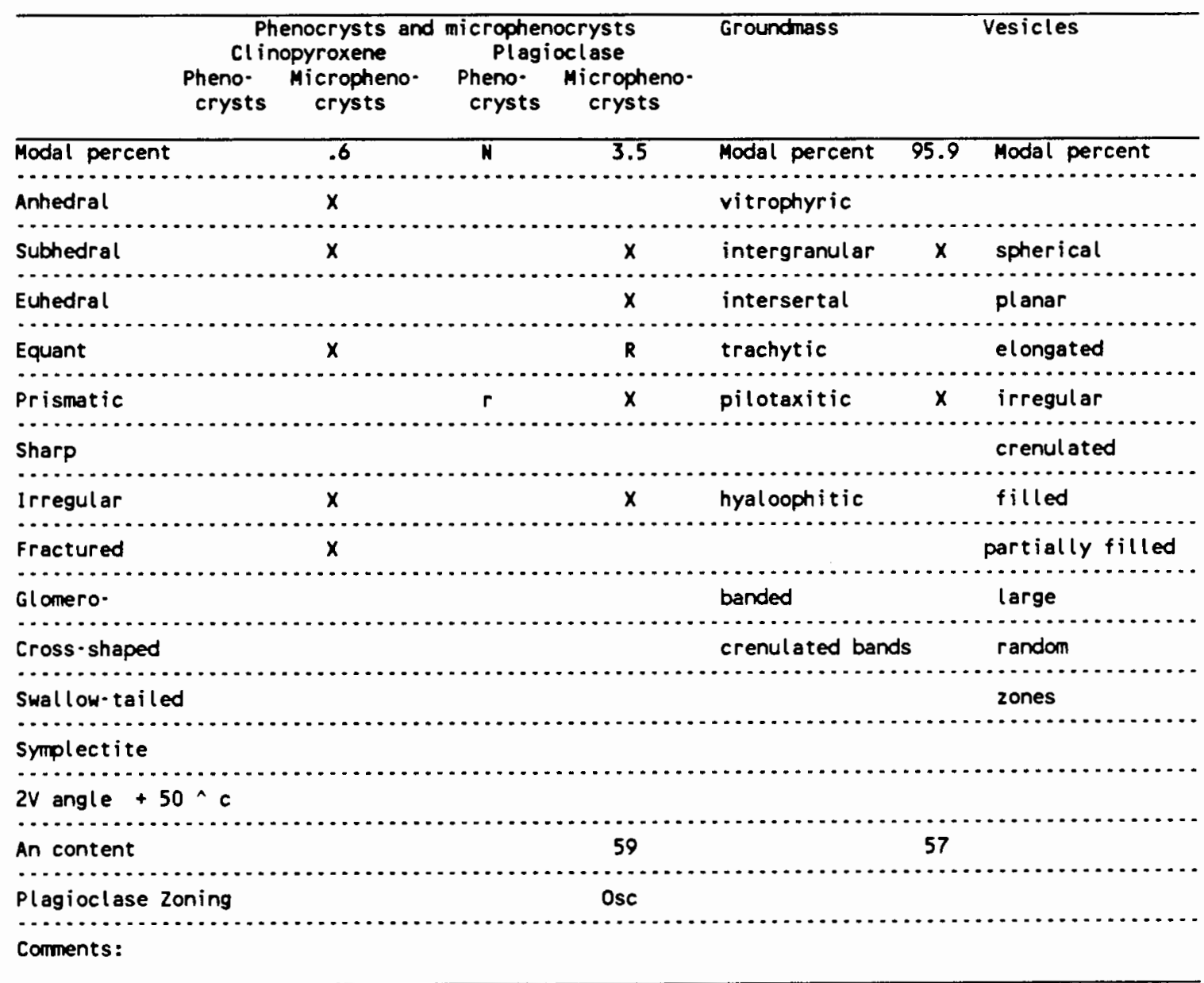


TABLE LXV

THIN SECTION DESCRIPTION FOR SAMPLE : $8 \cdot 21 \$ 3 \mathrm{C}$

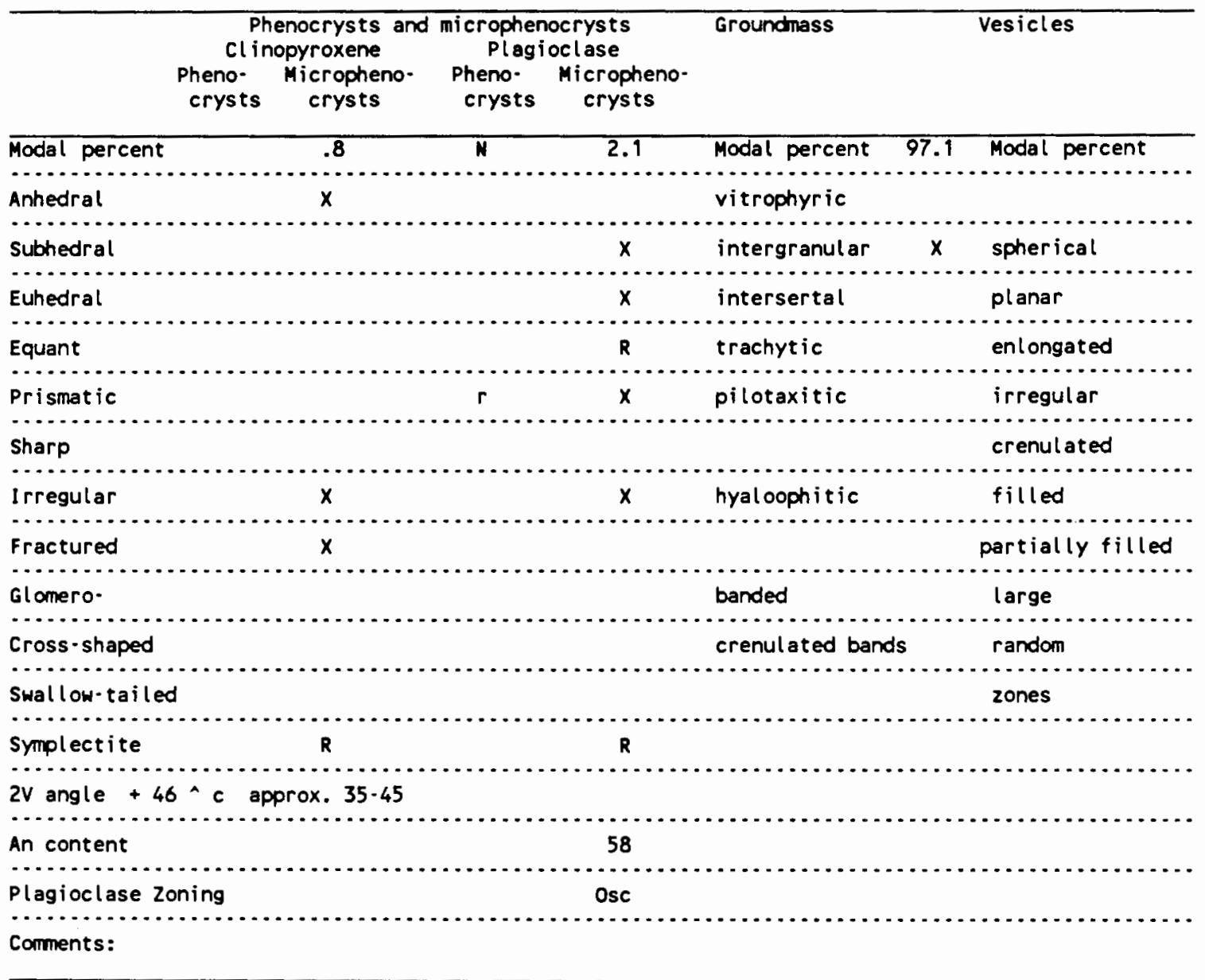


TABLE LXV

THIN SECTION DESCRIPTION FOR SAMPLE : 8-21\#3C

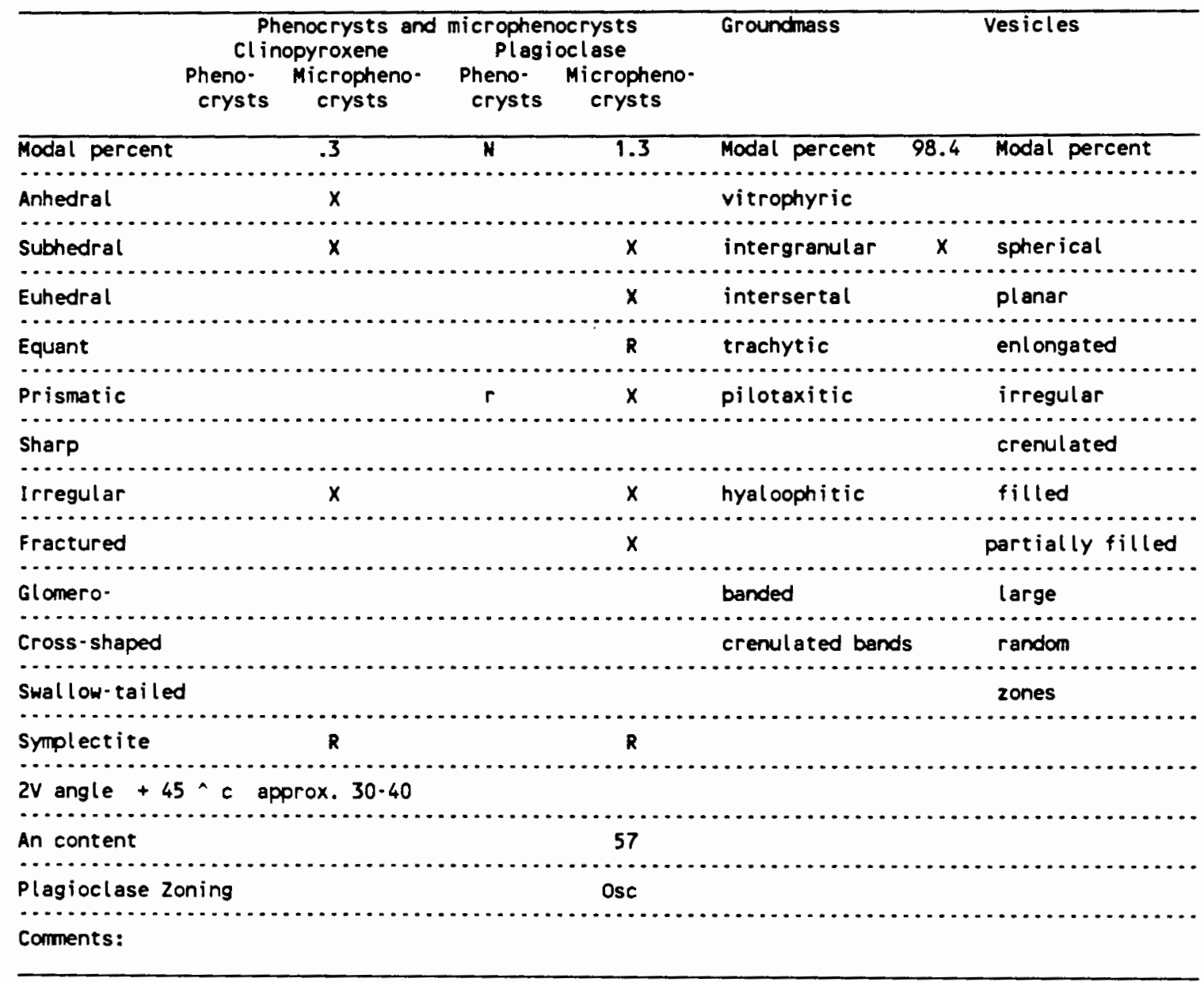


TABLE LXVI

THIN SECTION DESCRIPTION FOR SAMPLE : 8-21\#5C

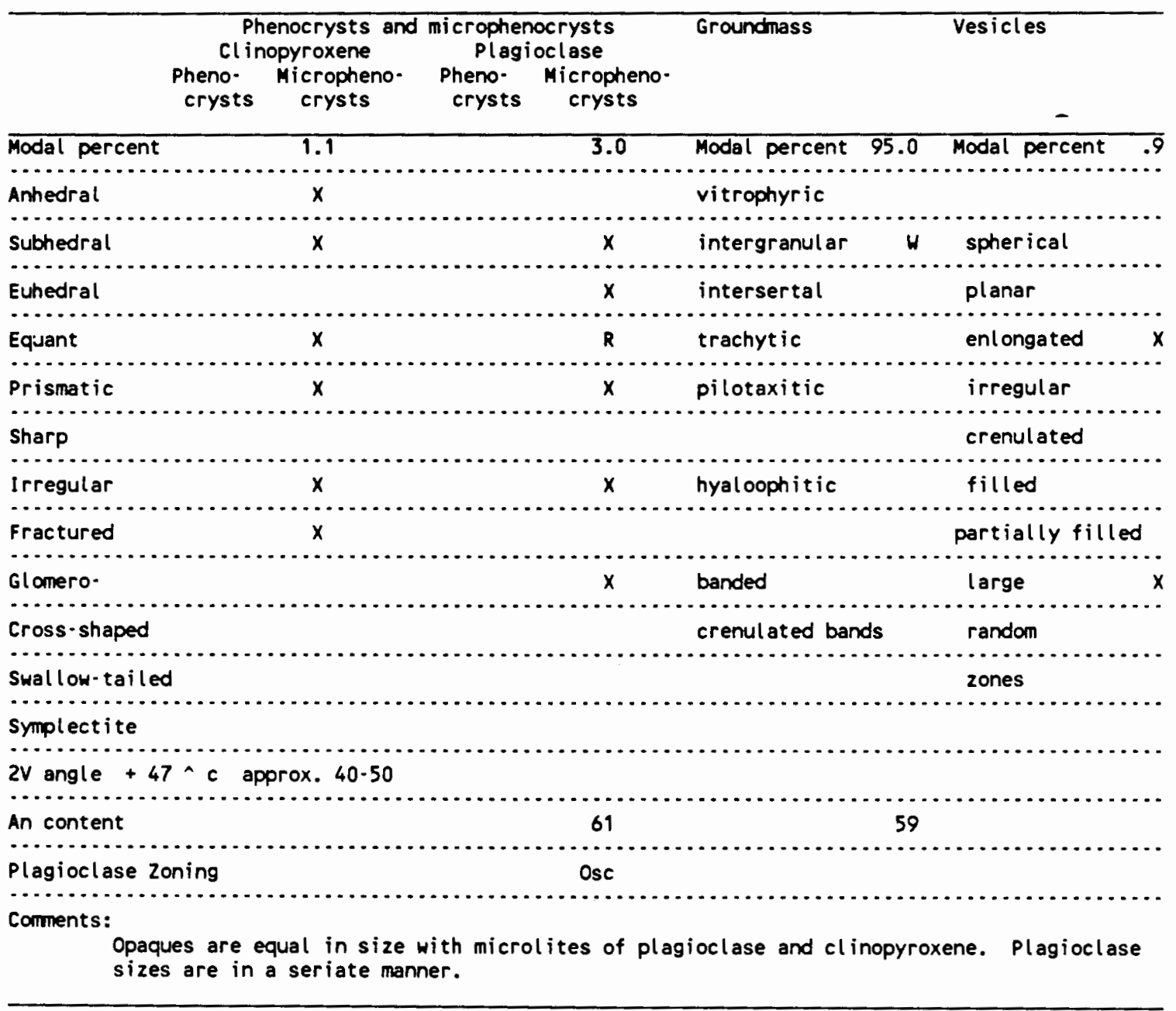


APPENDIX C

SUMMARY OF TRAVERSE INFORMATION 


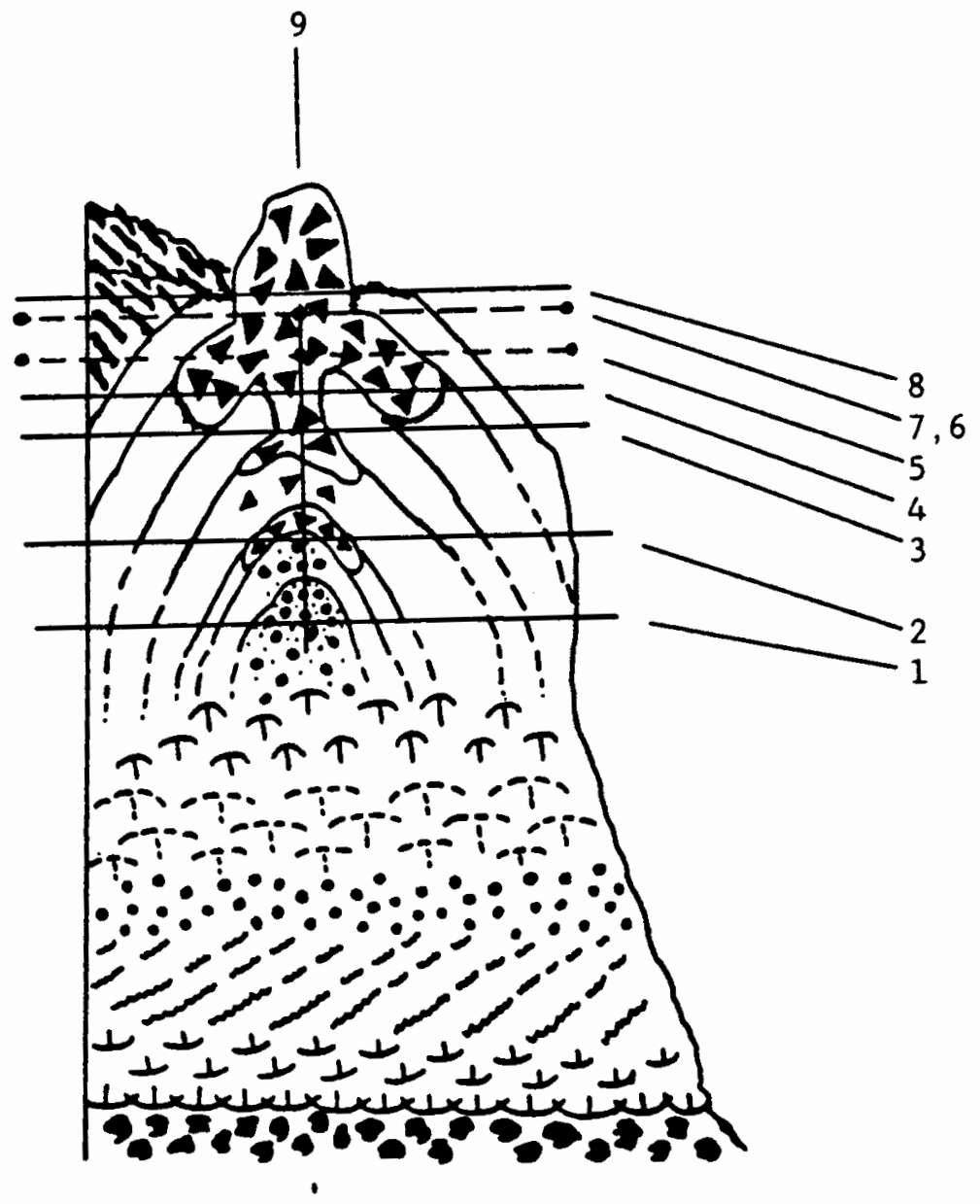

Figure 54. The position of each transverse are shown relative to the intraflow zones of the second cooling unit of the Troy flow. Each transverse label corresponds to a title label in the following tables of collected data. The solid circles at the ends of certain lines indicates the transverses were parallel to the plane of the central spine. 
TABLE XLVII

DEFINITIONS AND SYMBOLS FOR HORIZONTAL AND VERTICAL TRAVERSES

\section{Definitions and general characteristics :}

Region 1 - Region 1 consists of black, glassy-textured basalt, that is vertically jointed with joints spaced one or two per two foot interval. Differential weathering has accentuated the visible aligrment of microphenocrysts of plagioclase, which are parallel to the inner dipping breccia of the structure. Rock within this region fractures conchoidally. In the upper portions of an explosion structure, region 1 rock will form inward curving confining walls of black glassy-textured basalt that are parallel and surround region 2 rock and or the breccia of region 3 . The confining walls can narrow to a single projecting arm of region 1 besalt (called hereafter as a basaltic arm) that penetrates into region 2 basalt and or the breccia of region 3 . Typically an individual arm or basaltic arm can be traced back in a portion of the confining walls as a single layer of region 1 besalt separated by joint traces form the remaining basalt. Gradational contact with region 2 .

Region 2 - Region 2 is comprised of isolated vesicular clasts/pockets (see definitions section) or groups of vesicular clasts/pockets that are within a black glassy-textured basaltic matrix. Vesicles commonly compose less than $50 \%$ of the clasts/pockets and the vesicles can be stretched or spherical. Obvious boundaries are not visible in hand samples. clasts/pockets sizes increase towards region 3. A sharp visble contact exists against region 3 and the vertical joints begin to tilt towards the contact with region 3 .

Region 3 - Region 3 contains convex upward jointing with its margins continuing in common orientation with that within region 2 (comonly the trace of the joint can be followed from region 3 , where the trace is horizontal into and through regions 2 and 1, where the trace has swung to vertical). The rock is made up of $80.90 \%$ clasts of various types (see table $?$ for data) and are colored from black to reddish-purple. The sharp contact with region 2 is marked by stretched clasts; elongation is parallel to the trace of the contact. Clast sizes increase away from the trace of the contact with region 2 and breccia grades from a peripheral outer matrix-supported zone to an inner clast-supported zone.

Symbols : Used in the following transverse and vertical transverse tables

8 - Breccia count not made here.

G - Breccia clasts or vesicular clasts/pockets were counted by grid method, where a $2 \times 2 \mathrm{ft}$ square grid was centered on a selected point and the number of clasts/pockets were counted.

+ Center of a $2 \times 2$ square grid that concidence with a selected point on the 100 foot tape (hereafter called an interval mark).

C - Covered

N - Vesicular clasts/pockets were not counted. 
TABLE XLVIII

HORITZONTAL GRID TRAVERSE 1 THROUGH STRUCTURES

\begin{tabular}{|c|c|c|}
\hline $\begin{array}{l}\text { Distance from } \\
\text { starting point }\end{array}$ & $\begin{array}{l}1 \text { Number } ! \\
! \text { of clasts ! }\end{array}$ & Comments \\
\hline $0+$ & OG & Region 1: Joint trend N55E 82NW. \\
\hline $10+$ & OG & Region 1: Joint trending change to N55E $43 \mathrm{NW}$. \\
\hline $20+$ & 76 & Region 2: Largest vesicular clasts/pockets to $20 \mathrm{~mm}$ in size. \\
\hline $30+$ & $10 G$ & Region 2: \\
\hline $40+$ & 416 & $\begin{array}{l}\text { Region 3: Abrupt increase in the size of clasts that become up to } \\
40 \mathrm{~mm} \text { in diameter and matrix supported. }\end{array}$ \\
\hline $50+$ & 476 & $\begin{array}{l}\text { Region 3: Large clasts up to } 150 \mathrm{~mm} \text { in diameter, but commonly } 40 \mathrm{~mm} \\
\text { in diameter. Majority of clasts are colored black. }\end{array}$ \\
\hline $60+$ & C & Covered \\
\hline
\end{tabular}


TABLE XLIX

HORIZONTAL TRAVERSE 2 THROUGH AN EXPLOSIOH STRUCTURE

\begin{tabular}{|c|c|c|}
\hline $\begin{array}{l}\text { Distance from } \\
\text { starting point }\end{array}$ & $\begin{array}{l}\text { ! Number ! } \\
\text { ! of clasts ! }\end{array}$ & Comments \\
\hline $0-30$ & 0 & Region 1. \\
\hline $30-40$ & $N$ & $\begin{array}{l}\text { Region 2: Predominantly convex up joints and joint traces are } \\
\text { separated by } 40 \text { to } 150 \mathrm{~mm} \text {. Joint traces may pinch out towards } \\
\text { previous interval of region } 1 \text {-type rock. Joint traces undulate } \\
\text { similar to small ripple marks with amplitudes of } 10 \text { to } 20 \mathrm{~mm} \text { and } \\
\text { wavelengths of up to } 500 \mathrm{~mm} \text {. Vesicles are small in diameter, < } 1 \\
\mathrm{~mm} \text {, and filled with reddish brown material. }\end{array}$ \\
\hline 40.50 & $\mathbf{N}$ & $\begin{array}{l}\text { Region 2: Contains vesicular or scoriaceous clasts/pockets and the } \\
\text { vesicles may be filled with either brownish yellow to greenish } \\
\text { yellow, but commonly reddish brown material. clasts/pockets have } \\
\text { distinct boundaries of brownish red rims of } 1 \text { to } 2 \mathrm{~mm} \text { thick within } \\
\text { a black basaltic matrix. Larger-sized clasts/pockets often } \\
\text { consist of more than one vesicular to scoriaceous clasts/pockets } \\
\text { welded together as a single clast with reddish brown rims } \\
\text { separating each individual clast/pocket. Predominantly convex up } \\
\text { jointing with irregular thicknesses separating individual joint } \\
\text { traces by } 50 \text { to } 500 \mathrm{~mm} \text {. Similar small undulating surfaces are } \\
\text { observed as in interval } 30-40 \text {. }\end{array}$ \\
\hline
\end{tabular}

$50-60$

$60 \cdot 70$

$70-80$

$80+$
Region 2: Contains similar clasts/pockets patterns, except reddish brown rims were observed to surround nonvesicular basalt clasts as well. Number of clasts/pockets increases upward and grades into region 3. Similar jointing and surface patterns on joints as with interval $40-50$.

Region 3: Contains clasts of vesicular, scoriaceous, and aphyric basalt surrounded in a reddish-purple-colored basal tic matrix. Convex up jointing less pronounced and rock appears more massive (non-jointed).

Region 3: Grid count was performed on breccia face perpendicular to this interval. Clasts counts are complied in TABLE LII. Clasts counts: 13 clasts $>60 \mathrm{~mm}, 88+$ clasts $<60 \mathrm{~mm} ; 9 \mathrm{clasts}>60 \mathrm{~mm}$ and 1 clast > 400m, $50+$ clasts $<60 \mathrm{~mm} ; 9$ clasts $>60 \mathrm{~mm}, 80+$ clasts $<60 \mathrm{~mm}$; 5 clasts $>60 \mathrm{~mm}, 80+$ clasts $<60 \mathrm{~mm}$.

Section discontinued because of cliff. 
TABLE L

HORITZONTAL TRAVERSE 3 THROUGH AN EXPLOSION STRUCTURE

$\begin{array}{lll}\text { Distance from } \quad \text { Number ! } & \text { Comments } \\ \text { starting point } & \text { ! of clasts ! }\end{array}$

\begin{tabular}{|c|c|c|}
\hline 0.9 & 8 & $\begin{array}{l}\text { Region 2: Vesicular clasts/pockets up to } 150 \mathrm{~mm} \text { in diameter. } \\
\text { Abrupt contact trace with abjacent region } 3 .\end{array}$ \\
\hline $1-7$ & B & $\begin{array}{l}\text { Region 3: Grades inward to more open breccia and grades downward } \\
\text { into region } 2 \text { type rock with convex-up jointing. }\end{array}$ \\
\hline $7 \cdot 10$ & B & $\begin{array}{l}\text { Region 3: Composed of extremely small-sized clasts of breccia, less } \\
\text { than } 20 \mathrm{~mm} \text {. Rare vesicular clasts have milky-white to clear- } \\
\text { colored opal filled vesicles. Grades downward into region } 2 \text {-type } \\
\text { rock that consist of chaotic elongated plate-shaped fragments. } \\
\text { Vesicular clasts/pockets are in a black blasaltic matrix and } \\
\text { vesicles are filled by blue-green material. Isolated reddish- } \\
\text { purple-colored basalt surround open voids within this region } 2 \text {-type } \\
\text { rock. Region } 3 \text {-type rock grades upward into larger sized clasts } \\
\text { similar to the previous interval }(1-7) \text {. }\end{array}$ \\
\hline $11-15$ & B & $\begin{array}{l}\text { Region 3: Larger sized clasts of breccia similar to interval }(1-7) \text {. } \\
\text { This interval grades downward into elongated plate-shaped fragments } \\
\text { that are fractured along convex-up joints. Joints are coated with } \\
\text { clear-colored, mamillary-shaped material. Plate-shaped fragments } \\
\text { are commonly } 5 \text { to } 20 \mathrm{~mm} \text { thick, but may be up to } 70 \mathrm{~mm} \text { thick and } \\
\text { commonly } 50 \text { to } 60 \mathrm{~mm} \text { long, but may be up to } 250 \mathrm{~mm} \text { in length. } \\
\text { Plate-shaped fragments pinch and swell and the outer surfaces have } \\
\text { ripple-like patterns. }\end{array}$ \\
\hline $15 \cdot 32$ & N & $\begin{array}{l}\text { Region 2: Elongated plate-shaped fragments are observed, but the } \\
\text { prominance diminishes downward from this interval. }\end{array}$ \\
\hline $32 \cdot 35 c$ & B & Region 3. \\
\hline $35 \cdot 54$ & C & Covered section. \\
\hline $54-60$ & 31 & $\begin{array}{l}\text { Region 3: Grades into a clast-supported zone where clast size } \\
\text { increases and void space between clasts increases. Clast-supported } \\
\text { zone marked by a large v-shaped notch in the breccia spine, some } \\
100 \text { feet deep into slope of the valley walls and approximately } 50 \\
\text { feet wide at the opening of the } v \text { shaped mouth. clast-supported } \\
\text { zone is less resistant to weathering. Line count of this interval } \\
\text { resulted in } 27 \text { clasts less than } 60 \mathrm{~mm} \text { in size and } 4 \text { clasts over } 60 \\
\mathrm{~mm} \text { Clasts in the } v \text {-shaped notch of clasts-supported breccia } \\
\text { increase to rare blocks up to } 1 \mathrm{~m} \text { in diameter. A horizontal } \\
\text { transverse was completed along the western arm of this notch and is } \\
\text { horizontal transverse number } 4 \text { (see this transverse for details). }\end{array}$ \\
\hline
\end{tabular}


TABLE LI

HORITZONTAL TRAVERSE 4 THROUGH AN EXPLOSION STRUCTURE

\begin{tabular}{|c|c|c|}
\hline $\begin{array}{l}\text { Distance from } \\
\text { starting point }\end{array}$ & $\begin{array}{l}\text { ! Number ! } \\
\text { ! of clasts ! }\end{array}$ & Comments \\
\hline $0-13$ & 9 & $\begin{array}{l}\text { Region 2: Includes a } 4 \mathrm{ft} \text { thick interval of reddish purple } \\
\text { vesicular clasts. }\end{array}$ \\
\hline $13-15$ & 11 & Region 2: Jointed with dip of joints towards adjacent region 3 . \\
\hline $16-29$ & B & Region 3: Clasts have interlocking pattern and welded character. \\
\hline $29-39$ & 8 & Region 2: Jointed with dip towards last interval $(16.29)$. \\
\hline $39 \cdot 76$ & 0 & Region 1. \\
\hline $76-102$ & $37 \mathrm{G}$ & $\begin{array}{l}\text { Region 2: Grid counts at interval mark }{ }^{\star} 81 \text { were } 30 \text { vesicle } \\
\text { clasts/pockets, at interval mark } 86 \text { the total was } 11 \text {, and finally } \\
\text { at interval mark } 91 \text {, the total was } 12 \text {. }\end{array}$ \\
\hline $102 \cdot 148$ & 0 & $\begin{array}{l}\text { Region 1: An interval }(120-122) \text { that is colored reddish purple and } \\
\text { containes no clasts. Surface textures observed at intervals } 105 \\
\text { and } 134 \text { are rippled. Surface appearance is similar to small } \\
\text { sedimentary ripple marks (< } 2 \mathrm{~cm} \text { in amplitude). Three successive } \\
\text { layers of basalt with the rippled surface texture overlie each } \\
\text { other and each layer is } 30 \text { to } 40 \mathrm{~mm} \text { thick. }\end{array}$ \\
\hline $148-156$ & $26 G$ & $\begin{array}{l}\text { Region 2: Rare clasts/pockets up to } 120 \mathrm{~mm} \text { in diameter and the } \\
\text { number of clasts/pockets increases towards the next interval; } 156- \\
162 \text {. Grid count at interval mark } 152 \text { with total at } 39 \text { clasts. }\end{array}$ \\
\hline $156-162$ & B & $\begin{array}{l}\text { Region 3: Rare clasts up to } 200 \mathrm{~mm} \text { in diameter but commonly less } \\
\text { than } 40 \mathrm{~mm} \text { in diameter. }\end{array}$ \\
\hline $162 \cdot 169$ & 14 & $\begin{array}{l}\text { Region 2: Joints end abruptly into overlying region } 3 \text {. Clast sizes } \\
\text { increase towards overlying region } 3 \text {. }\end{array}$ \\
\hline $169 \cdot 178 \mathrm{c}$ & $\mathbf{B}$ & Region 3: Covered after interval mark 178. \\
\hline
\end{tabular}

* interval mark is at point along the 100 foot tape the 2 by 2 foot square grid was centered on. 
TABLE LII

DESCRIPTIONS FOR CLAST TYPES USED DURING COUNTING TRAVERSES

\section{CLAST TYPES :}

BVA - Clast is a composite of clasts or fragments of black vesicular or non-vesicular, vitrophyric to intergranular-textured besalt with a reddish purple colored basaltic matrix. The matrix can be twisted, swirled, or stretched into layers that can be cracked or fractured. The cracks can contain very small fragments of rock, $\leq 1 \mathrm{~mm}$ in size. Some block-sized clasts are coated with a fused layer, up to $1 \mathrm{~mm}$ thick, of finely brecciated black-colored basalt and reddish-purple-colored matrix. Shapes of clasts range from sharp angular to planar to agglutinated froms. Rare empty interclast voids.

S - Clast composed of black or reddish colored scoriaceous basalt. Scoriaceous clasts show two types of either randomly placed vesicles through the clast or vesicles are concentrated in inflated vesicular margins. Shapes of clasts range from subrounded forms for the random vesicle type to plate-shaped forms for the inflated type of clast.

PAH - Clast composed of vesicular basalt with vesicles that are elongated and twisted parallel to the surface shape of the clast. Vesicles are up to $50 \mathrm{~mm}$ long, 2 to $3 \mathrm{~mm}$ thick, and up to $20 \mathrm{~mm}$ wide with vesicles often filled along the peripheral surface by dark green material. Clasts are colored blue gray internally and grade outward from yellow green to an orange-brown rim. Clasts have ropy surface texture. Clast shapes have generally plate-like forms.

SP - Measurement of void space difficult to measure with 100 foot line method.

\section{TABLE LVII}

CLAST COUNTING GRID FOR HORITZONTAL TRAVERSE 2

THROUGH A CENTRAL SPINE

\begin{tabular}{|c|c|c|}
\hline$! \quad !$ & & \\
\hline ! Position !- & $\cdots$ & \\
\hline ! Label ! & & \\
\hline$!$ & $<64 \mathrm{~mm}$ & $>64 \mathrm{~mm}$ \\
\hline 1 & 88 & 13 \\
\hline 2 & 50 & 9 \\
\hline 3 & 80 & 9 \\
\hline 4 & 80 & 5 \\
\hline TOTALS: & 278 & 36 \\
\hline Percentage $(x)$ & 89 & 11 \\
\hline
\end{tabular}


TABLE LIV

HORITZONTAL TRAVERSE 5 CLAST GRID COUNTING THROUGH A STEEPLY DIPPING BRECCIA ZONE

\begin{tabular}{|c|c|c|c|c|c|c|c|c|c|c|c|c|}
\hline \multirow{3}{*}{$\begin{array}{l}\text { Position } \\
! \quad \text { Label } \\
\end{array}$} & \multicolumn{12}{|c|}{ Type of clast } \\
\hline & ! & & & $!$ & $s$ & & ! & & & 1 & & $\mathrm{P}$ \\
\hline & ! & $<64 \pi m$ & $>64 \mathrm{~mm}$ & $!$ & $<64 \pi m$ & $>64 m m$ & $!$ & $<64 \mathrm{~mm}$ & $>64 \pi m$ & $!$ & $<64 \pi m$ & $>64 \mathrm{~mm}$ \\
\hline 1 & & $\cdots$ & 8 & & -. & 2 & & $\cdots$ & 0 & & $\cdots$ & -. \\
\hline 2 & & 220 & 6 & & 12 & 9 & & 0 & 1 & & $\cdots$ & $\cdots$ \\
\hline 3 & & 176 & 10 & & 12 & 2 & & 0 & 1 & & $\cdots$ & $\cdots$ \\
\hline 4 & & 248 & 7 & & 28 & 13 & & 0 & 0 & & $\cdots$ & $\cdots$ \\
\hline 5 & & 200 & 6 & & 8 & 8 & & 0 & 4 & & $\cdots$ & $\cdots$ \\
\hline 6 & & 140 & 8 & & 8 & 7 & & 0 & 0 & & $\cdots$ & -. \\
\hline TOTALS: & & 984 & 45 & & 68 & 41 & & 0 & 6 & & $\cdots$ & $\cdots$ \\
\hline Percentage(\% & & 86 & 4 & & 6 & 4 & & 0 & 1 & & $\cdots$ & $\cdots$ \\
\hline
\end{tabular}

TABLE LV

HORITZONTAL LINE COUNTING TRAVERSES 6 AND 7 IN A CENTRAL SPINE

\begin{tabular}{|c|c|c|c|c|c|c|c|c|c|c|c|c|}
\hline & $!$ & & & & & Type & $f c$ & & & & & \\
\hline ! Label & $i$ & B & & $!$ & $s$ & & $!$ & & & $!$ & & SP \\
\hline$!$ & $!$ & $<64 \mathrm{~mm}$ & $>64 \mathrm{~mm}$ & $!$ & $<64 \mathrm{~mm}$ & $>64 \mathrm{~mm}$ & $!$ & $<64 \mathrm{~mm}$ & $>64 \mathrm{~mm}$ & $!$ & $<64 \mathrm{~mm}$ & $>64 \mathrm{~mm}$ \\
\hline 5 & & 89 & 22 & & 29 & 3 & & 0 & 1 & & 5 & 1 \\
\hline 6 & & 141 & 11 & & 42 & 17 & & 1 & 8 & & 0 & 2 \\
\hline TOTALS: & & 230 & 33 & & 71 & 20 & & 1 & 9 & & 5 & 3 \\
\hline Percentage ( $x$ & & 62 & 9 & & 19 & 5 & & 0 & 2 & & 1 & 1 \\
\hline
\end{tabular}


TABLE LVI

HORIZONTAL GRID TRAVERSE 8 THROUGH AN EXPLOSION STRUCTURE

$\begin{array}{ll}\text { Distance from } & \text { Comments } \\ \text { starting point ! of clasts ! } & \end{array}$

\begin{tabular}{|c|c|c|}
\hline $\mathrm{CO}-5$ & B & $\begin{array}{l}\text { Region 3: no horizontal or vertical jointing pattern (massive) as } \\
\text { observed in other region } 3 \text {-type rock. Clast types range from blac } \\
\text { nonvesicular to vesicular basalt to scoriaceous clasts in a } \\
\text { reddish-purple basaltic matrix. Further upslope, approximately } 15 \\
\text { to } 30 \text { feet, an isolated outcrop of region } 1 \text { basalt is exposed. } \\
\text { This region } 1 \text { has no dominant jointing pattern but has fractures } \\
\text { that weather spheroidally into irregular-sized cobbles and pebbles }\end{array}$ \\
\hline $5-7$ & 0 & $\begin{array}{l}\text { Region 1: a sharp contact trace with region } 3 \text { and is vertically } \\
\text { jointed. No region } 2 \cdot \text { type rock was seen here, but instead a } \\
\text { transformation between region } 1 \text { and region } 3-\text { type rocks. }\end{array}$ \\
\hline $7 \cdot 19$ & B & Region 3: forms resistant ridges between intervening cover. \\
\hline $19-34$ & 0 & $\begin{array}{l}\text { Region 1: vertical joints that, where fractured, break along } \\
\text { spherical fractures into small spheres or fluted spheroids, \10 } \\
\text { in diameter. Distinct, darker black matrix surrounds broken } \\
\text { spheres. }\end{array}$ \\
\hline $34 \cdot 40$ & 0 & $\begin{array}{l}\text { Region 2: similar fracture patterns of spheres, but with diameters } \\
\text { only up to } 5 \mathrm{~mm} \text {. Streaks of reddish-purple-colored basalt } \\
\text { intermixed within black basalt and vesicular clasts/pockets } \\
\text { observed within these colored streaks. vesicles of clasts/pockets } \\
\text { can be filled with greenish-yellow material and vesicle shapes } \\
\text { range from circular to elongated and } \leq 2 \mathrm{~mm} \text { in diameter. }\end{array}$ \\
\hline $40 \cdot 66$ & C & Covered interval overlies region 3 of transverse 2 field number. \\
\hline $66-78$ & 0 & $\begin{array}{l}\text { Region 1: similar spheroidal fracture pattern, but breaks into } \\
\text { sharp angular forms. Poorly developed vertical joints. }\end{array}$ \\
\hline $78-98 \mathrm{C}$ & B & Region 3 for 2 feet then covered. \\
\hline $98-118$ & 0 & $\begin{array}{l}\text { Region 1: irregular wavy vertical and platy joints, that fracture } \\
\text { into spheroidal forms commonly } \leq 20 \mathrm{~mm} \text { in diameter, but may be up } \\
\text { to } 30 \mathrm{~mm} \text { in diameter. }\end{array}$ \\
\hline $18-131$ & B & $\begin{array}{l}\text { Region 3: individual clasts composed of single clasts or a fused } \\
\text { group of clasts that form one welded, distinct individual clast. } \\
\text { Breccia is clast-supported with a thin coating of black aphyric } \\
\text { basalt or reddish-purple-colored basalt. }\end{array}$ \\
\hline
\end{tabular}

$131+$

Intervening cliff ended transverse. 
TABLE LVII

VERTICAL LINE TRAVERSE 9 THROUGH AN EXPLOSION STRUCTURE

$\begin{array}{ll}\text { Distance from } & \text { Mumber ! Comments } \\ \text { starting point } & \text { of clasts ! }\end{array}$

\begin{tabular}{|c|c|c|}
\hline $0-10$ & 0 & $\begin{array}{l}\text { Region 1: lrregular wavy platy jointing, spaced up to } 250 \mathrm{~mm} \text {, but } \\
\text { commonly less than } 70 \mathrm{~mm} \text {. Strong NH joint pattern. No breccia or } \\
\text { vesicular clasts/pockets observed. }\end{array}$ \\
\hline $10-20$ & 0 & $\begin{array}{l}\text { Region 1: Containing random microphenocrysts. Platy jointed with } \\
\text { large plates, up to } 400 \mathrm{~mm} \text { in length but commonly } 100 \mathrm{~mm} \text {. }\end{array}$ \\
\hline $20-30$ & 0 & Region 1: Predominant vertical joints lacking horizontal jointing. \\
\hline $30-40$ & 0 & $\begin{array}{l}\text { Region 1: Containing vertically jointed basalt that breaks into } \\
\text { small irregular fragments. Greenish-colored streaks produced by } \\
\text { deuteric alteration. }\end{array}$ \\
\hline $40-50$ & 0 & $\begin{array}{l}\text { Region 1: Tilted joints towards near adjacent breccia zone. } \\
\text { Similar deuteric alteration observed. }\end{array}$ \\
\hline $50-60$ & C & $\begin{array}{l}\text { Region 1: For approximately } 1 \mathrm{~m} \text { with tilted vertical joints toward } \\
\text { superjacent region } 2 \text {. Region } 2 \text { for approximately } 2.5 \mathrm{~m} \text { with } \\
\text { horitzonal joints and vesicular clasts/pockets. Vesicular } \\
\text { clasts/pockets commonly one or two per foot and increasing in } \\
\text { number upwards. Vesicles filled with reddish brown material. }\end{array}$ \\
\hline $60 \cdot 70$ & C & $\begin{array}{l}\text { Region 2: Horizontal joints and increasing number of } \\
\text { clasts/pockets. Vesicles filled with reddish-brown material. }\end{array}$ \\
\hline $70-80$ & $\mathrm{C}$ & $\begin{array}{l}\text { Region 2: Breaks into very angular fragments. Vesicular } \\
\text { clasts/pockets in black basalt with microphenocrysts of } \\
\text { plagioclase. Individual layers of basalt separated by joints } \\
\text { (basalt arms) that tilt towards horizontal as each arm nears the } \\
\text { trace of the region } 3 \text { breccia. }\end{array}$ \\
\hline $80 \cdot 90+$ & B & $\begin{array}{l}\text { Region 3: Basalt arms of region } 2 \text { penetrate and fragment within the } \\
\text { breccia layers. }\end{array}$ \\
\hline
\end{tabular}


TABLE LVIII

SUMMARY OF BRECCIA TRENDS AND LOCATIONS

\begin{tabular}{|c|c|c|}
\hline Location or stratigraphic label & Flow & Measurement of bearings \\
\hline $\begin{array}{l}\text { NE } 1 / 4, \text { SE } 1 / 4, \text { SE } 1 / 4 \text { Sect } 31 \\
\text { T5N R43E TroY } 71 / 2\end{array}$ & Troy & $\begin{array}{l}\text { N30E, N25E, N45E, N60E, N32E, N45E, N60E, N32E, N25E, N30E } \\
\text { N55E, N32E, N28E, N23E, N20E, N45E, N45E }\end{array}$ \\
\hline $\begin{array}{l}\text { WR } \\
\text { WR }\end{array}$ & $\begin{array}{l}\text { Troy } \\
\text { LGR }\end{array}$ & $\begin{array}{l}\text { N87W, N70E, N80W, N82W, N70E } \\
\text { N55W }\end{array}$ \\
\hline $\begin{array}{l}U \\
U \\
U\end{array}$ & $\begin{array}{l}\text { UGR } \\
\text { TrOY } \\
\text { LGR }\end{array}$ & $\begin{array}{l}\text { N3OH, N10H } \\
\text { N32H, N14H } \\
\text { N32H, N15H, N14H }\end{array}$ \\
\hline HC & Troy & N30E, N35E \\
\hline $\begin{array}{l}M C \\
M C \\
M C\end{array}$ & $\begin{array}{r}\text { UGR } \\
\text { TrOY } \\
\text { LGR }\end{array}$ & $\begin{array}{l}\text { N5E, N7E, N5E, N40E } \\
\text { N78E, N60E, N64E, N70E, N65E, N65E, N85E } \\
\text { N60E, N80E, N70E, N72E, N62E, N70E, N30E, N35E }\end{array}$ \\
\hline LF & $\begin{array}{l}\text { Troy } \\
\text { LGR }\end{array}$ & $\begin{array}{l}\text { N5E, N10E } \\
\text { N55H, N38H }\end{array}$ \\
\hline$E F$ & $\begin{array}{l}\text { Troy } \\
\text { LGR }\end{array}$ & $\begin{array}{l}\text { N10E, N25E, N38E, N22E, N47E, N36E, N38E, N45E, N27E, N37E } \\
N 16 E, N 37 E, N 18 E, N 15 E, N 43 E, N 7 E, N 5 H, N 12 H, N 2 H, N 55 E, N 29 \\
N 35 H, N 49 H, N 36 H, N 38 H, N 28 H, N 56 H\end{array}$ \\
\hline $\mathbf{F}$ & UGR & N60E, N45E, N20E, N38E \\
\hline SG & Troy & N3OE, N4OE \\
\hline SC1 & UGR 1 & \\
\hline SC1 & UGR2 & 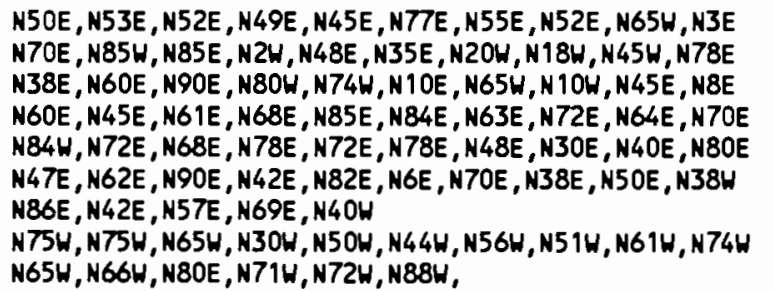 \\
\hline
\end{tabular}


TABLE LVIII CONTINUED

SUMMARY OF BRECCIA TRENDS AND LOCATIONS

\begin{tabular}{|c|c|c|}
\hline Location or stratigraphic label & FloH & Measurement of bearings \\
\hline SC2 & $\begin{array}{l}\text { UGR1 } \\
\text { UGR2 }\end{array}$ & $\begin{array}{l}\text { N55E, N71E, N51E, N71E, N87W, N8E, N68H, N67H, N88W, N88E } \\
\text { N60E, N60W, N78H, N80W, N85W, N79W, N78W, N89W, N74E, N67E } \\
\text { N80W, N88E, N80E } \\
\text { N88W,N64W,N74W, N6OW.N90W }\end{array}$ \\
\hline $\begin{array}{l}\text { NW } 1 / 4, \text { SE } 1 / 4, \text { NE } 1 / 4 \text { Sect } 9 \\
\text { T5N R } 43 E \text { Troy QUAD }\end{array}$ & LGR & N4TW, N4OW, N22W, N2OW \\
\hline $\begin{array}{l}\text { SW1 } 14, \text { NW } 1 / 4, \text { NE } 1 / 4 \text { Sect } 9 \\
\text { T5N R43E Troy Quad }\end{array}$ & Troy & N2OE \\
\hline $\begin{array}{l}\text { NE1/4, NE } 1 / 4 \text {, NW1/4 Sect } 9 \\
\text { T5N R43E Troy Quad }\end{array}$ & Troy & N2E \\
\hline $\begin{array}{l}\text { NE1/4, NW1/4, NW } 1 / 4 \text { Sect } 9 \\
\text { T5N R43E Troy Quad }\end{array}$ & Troy & N20E, N57E, N4OE, N65E, N55E \\
\hline $\begin{array}{l}\text { NW1 } 1 / 4, \text { SE } 1 / 4, \text { NW1/4 Sect } 10 \\
\text { T5N R43E Troy Quad }\end{array}$ & Troy & $N 41 E, N 23 E, N 47 E, N 15 E, N 29 E, N 7 E, N 31 E$ \\
\hline $\begin{array}{l}\text { SE } 1 / 4, \text { SE } 1 / 4, N E 1 / 4 \text { Sect } 15 \\
\text { TSN R43E TroY Quad }\end{array}$ & $\begin{array}{l}\text { LGR1 } \\
\text { LGR2 }\end{array}$ & $\begin{array}{l}\text { N35E, N28E, N33E, N19E, N23E, N30E, N25E, N31E } \\
\text { N42E, N21E }\end{array}$ \\
\hline
\end{tabular}


APPENDIX D

SUMMARY OF GEOCHEMICAL INFORMATION 
Summary of sample preparation

Each selective sample was treated in the following manner:

1) A sample was broken into several fragments and one fragment selected for thin section (to avoid any containation from cutting oils or water during the cutting/polishing operation).

2) Remaining fragments were separated in two groups. The first group of fragments was saved and the second group was then chipped (rock chipper).

3) Any chips with possible hammer marks or crusher marks were removed. Also precautions for special samples listed in TABLE LIX were initiated at this point. Sample chips marked by symbol ( $\$$ ) were separated from altered or weathered chips. Sample chips marked by symbol (*) were separated, because these chips were red in color and were samples containing breccia.

4) Next, the chips were randomly separated into three splits (approximately equal) and each split went to one of the three following analyzes: INAA, XRF, Mossbauer. 
TABLE LIX

SUMMARY OF SAMPLE LOCATION AND SAMPLE LABORATORY ANALYTICAL METHOOS

\begin{tabular}{|c|c|c|c|c|c|c|}
\hline \multirow{2}{*}{$\begin{array}{l}\text { stratigraphic } \\
\text { section label } \\
\text { sc1 }\end{array}$} & \multirow{2}{*}{$\begin{array}{l}\text { Location } \\
71 / 2 \text { minute quadrangle } \\
\text { NW1/4SE } 1 / 4 N W 1 / 4 \\
\text { Sect } 35 \text { T6N R43E } \\
\text { Troy }\end{array}$} & \multirow{2}{*}{$\begin{array}{l}\text { Sample } \\
\text { label } \\
8-22 \cdot \text { SC\#1 } \\
8-22 \cdot \text { SC\#2 } \\
\star 8-22 \cdot \text { SC } \# 2 B \\
8 \cdot 22 \cdot S C \# 3 \\
8-22 \cdot S C \# 4\end{array}$} & \multicolumn{4}{|c|}{$\begin{array}{l}\text { Labatory analytical method } \\
\text { Thin section INAA XRF Mossbaurer }\end{array}$} \\
\hline & & & $\begin{array}{l}Y \\
Y \\
Y\end{array}$ & $\begin{array}{l}Y \\
Y \\
Y \\
Y \\
Y\end{array}$ & & \\
\hline Wenaha.c & $\begin{array}{l}\text { SE1/4SE 1/4SE } 1 / 4 \\
\text { Sect } 31 \text { T6N R43E } \\
\text { TroY }\end{array}$ & $\begin{array}{l}8-20 \# 1 \\
8-20 \# 2 \\
8-20 \# 3 \\
8-20 \# 4 \\
8-20 \# 5\end{array}$ & $\begin{array}{l}Y \\
Y \\
Y \\
Y\end{array}$ & $\begin{array}{l}Y \\
Y \\
Y \\
Y \\
Y\end{array}$ & & \\
\hline Wenaha.B & $\begin{array}{l}\text { NE } 1 / 4 \text { SE } 1 / 4 \text { SE } 1 / 4 \\
\text { Sect } 31 \text { T6N R43E } \\
\text { TroY }\end{array}$ & $\begin{array}{l}8-22-T 1 A 1 \\
\star 8-22-T 1 A R \\
8-22-T 1 A 2 \\
8-22-T 1 A 3 \\
8-22-T 1 B \\
8-22-T 1 C\end{array}$ & $\begin{array}{l}Y \\
Y \\
Y \\
Y \\
Y\end{array}$ & $\begin{array}{l}Y \\
Y \\
Y \\
Y \\
Y\end{array}$ & & $\begin{array}{l}Y \\
Y \\
Y\end{array}$ \\
\hline WR & $\begin{array}{l}\text { SE } 1 / 4 N W 1 / 4 N E 1 / 4 \\
\text { Sect } 5 \text { T5N R } 43 E \\
\text { TroY }\end{array}$ & $\begin{array}{l}M M \\
M 1 \\
M 2 \\
M 3 \\
M 4 \\
S N \\
8 \cdot 22 \# 1 C \\
8-22 \# 3 C \\
8-22 \# 4 C\end{array}$ & $\begin{array}{l}Y \\
Y \\
Y \\
Y \\
Y \\
Y\end{array}$ & $\begin{array}{l}Y \\
Y \\
Y \\
Y \\
Y \\
Y \\
Y \\
Y \\
Y\end{array}$ & $\begin{array}{l}Y \\
Y \\
Y\end{array}$ & \\
\hline MC & $\begin{array}{l}\text { NW1/4SE } 1 / 4 N W 1 / 4 \\
\text { Sect } 3 \text { T5N R43E } \\
\text { Troy }\end{array}$ & \&MC4D & $Y$ & $Y$ & & \\
\hline$G C$ & $\begin{array}{l}\text { NE } 1 / 4 \text { SW1/4SW1/4 } \\
\text { Sect } 24 \text { TSN R43E } \\
\text { Troy }\end{array}$ & $\begin{array}{l}8 \cdot 21 \# 1 C C \\
8-21 \# 2 C \\
8 \cdot 21 \# 3 C \\
8-21 \# 4 C \\
8-21 \# 5 C\end{array}$ & $\begin{array}{l}Y \\
Y\end{array}$ & $\begin{array}{l}Y \\
Y \\
Y \\
Y \\
Y\end{array}$ & & \\
\hline$E F$ & $\begin{array}{l}\text { NW1/4NW1/4SE } 1 / 4 \\
\text { Sect } 9 \text { T5N R43E } \\
\text { Troy }\end{array}$ & $\begin{array}{r}\$ 8-21 \# 2 A \\
8-21 \# 3 A \\
8-21 \# 5 A \\
8-21 \# 6 A \\
8-21 \# 7 A\end{array}$ & $\begin{array}{l}Y \\
Y \\
Y \\
Y\end{array}$ & $\begin{array}{l}Y \\
Y \\
Y \\
Y \\
Y\end{array}$ & $\begin{array}{l}Y \\
Y \\
Y \\
Y \\
Y\end{array}$ & \\
\hline$E F$ & $\begin{array}{l}\text { NH1/4NH1/4SE } 1 / 4 \\
\text { Sect } 9 \text { TSN R } 43 E \\
\text { Troy }\end{array}$ & $\begin{array}{l}8-21 \# 3 B \\
8-21 \# 4 B\end{array}$ & & $\begin{array}{l}Y \\
Y\end{array}$ & & \\
\hline 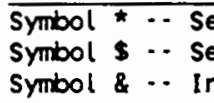 & $\begin{array}{l}\text { lected red colored chips } \\
\text { lected fresh chips } \\
\text { cluded in WR sample set }\end{array}$ & within breccia & sample & & & \\
\hline
\end{tabular}


TABLE LX

INAA VALUES, EQUIVALENT DEPTHS, DEPTH IN FLOW, ELEVATION OF

SAMPLES FROM SAMPLE SET ELLOIT FARM (EF)

\begin{tabular}{|c|c|c|c|c|c|}
\hline $\begin{array}{l}\overline{\text { SAMPLE }} \\
\text { LABELS }\end{array}$ & $\begin{array}{l}\text { *DEPTH } \\
\text { IN FLOW }\end{array}$ & $\begin{array}{l}\text { SELEVVATION } \\
\text { IN FLOW }\end{array}$ & LA & $\mathrm{CE}$ & SM \\
\hline $\begin{array}{l}8-21 \# 2 A \\
8 \cdot 21 \# 3 A \\
8-21 \# 5 A \\
8-21 \# 6 A \\
8-21 \# 7 A\end{array}$ & $\begin{array}{r}\&(100) 330.00 \\
(98) 325.00 \\
(83) 320.00 \\
(67) 315.00 \\
(19) 260.00\end{array}$ & $\begin{array}{l}2095 \\
2110 \\
2122 \\
2127 \\
2179\end{array}$ & $\begin{array}{l}36.10 \\
32.60 \\
31.00 \\
30.70 \\
30.60\end{array}$ & $\begin{array}{l}70.00 \\
68.00 \\
67.00 \\
65.00 \\
66.00\end{array}$ & $\begin{array}{l}9.59 \\
8.40 \\
8.35 \\
8.40 \\
7.83\end{array}$ \\
\hline LABELS & & & EU & TB & YB \\
\hline $\begin{array}{l}8-21 \# 2 A \\
8-21 \# 3 A \\
8-21 \# 5 A \\
8-21 \# 6 A \\
8-21 \# 7 A\end{array}$ & & & $\begin{array}{l}2.85 \\
2.63 \\
2.54 \\
2.52 \\
2.43\end{array}$ & $\begin{array}{l}1.70 \\
1.50 \\
1.70 \\
1.70 \\
1.40\end{array}$ & $\begin{array}{l}5.70 \\
5.40 \\
5.10 \\
5.00 \\
4.80\end{array}$ \\
\hline LABELS & & & LU & BA & co \\
\hline $\begin{array}{l}8 \cdot 21 \# 2 A \\
8-21 \# 3 A \\
8-21 \# 5 A \\
8 \cdot 21 \# 6 A \\
8 \cdot 21 \# 7 A\end{array}$ & & & $\begin{array}{l}0.66 \\
0.61 \\
0.61 \\
0.60 \\
0.59\end{array}$ & $\begin{array}{l}720.00 \\
500.00 \\
620.00 \\
550.00 \\
520.00\end{array}$ & $\begin{array}{r}0.00 \\
24.00 \\
22.00 \\
20.00 \\
19.00\end{array}$ \\
\hline LABELLS & & & +FEO & $+k_{2} 0$ & HF \\
\hline $\begin{array}{l}8-21 \# 2 A \\
8-21 \# 3 A \\
8-21 \# 5 A \\
8-21 \# 6 A \\
8 \cdot 21 \# 7 A\end{array}$ & & & $\begin{array}{l}8.19 \\
11.63 \\
11.13 \\
10.99 \\
11.63\end{array}$ & $\begin{array}{l}3.30 \\
1.60 \\
2.10 \\
2.50 \\
2.30\end{array}$ & $\begin{array}{l}6.80 \\
6.20 \\
6.40 \\
5.90 \\
6.20\end{array}$ \\
\hline LABELS & & & $+\mathrm{NA}_{2} \mathrm{O}$ & RB & SC \\
\hline $\begin{array}{l}8-21 \# 2 A \\
8-21 \# 3 A \\
8-21 \# 5 A \\
8-21 \# 6 A \\
8-21 \# 7 A\end{array}$ & & & $\begin{array}{l}3.69 \\
3.64 \\
3.52 \\
3.59 \\
3.48\end{array}$ & $\begin{array}{l}73.00 \\
48.00 \\
61.00 \\
49.00 \\
63.00\end{array}$ & $\begin{array}{l}34.79 \\
31.98 \\
32.41 \\
31.38 \\
31.69\end{array}$ \\
\hline LABELS & & & TA & TH & \\
\hline $\begin{array}{l}8 \cdot 21 \# 2 A \\
8-21 \# 3 A \\
8 \cdot 21 \# 5 A \\
8 \cdot 21 \# 6 A \\
8 \cdot 21 \# 7 A\end{array}$ & & & $\begin{array}{l}0.58 \\
0.51 \\
0.53 \\
0.55 \\
0.48\end{array}$ & $\begin{array}{l}6.90 \\
6.60 \\
6.60 \\
6.20 \\
7.20\end{array}$ & \\
\hline \multicolumn{6}{|c|}{$\begin{array}{l}\bar{Q}(\bar{x} x) \text { enclose equivalent depths used to compare concentrations against another sample se } \\
\text { in a hypothet ical flow of } 100 \text { feet thick. } \\
\text { * Depth in flow is calculated from field elevations during measurement of stratigraphic } \\
\text { section } \\
\text { s Elevation of the sample within the flow was measured during stratigraphic section or } \\
\text { traverse measurements } \\
+ \text { Oxides concentrations in weight percent (iron is in total feo) and remaining } \\
\text { concentrations in part per million }\end{array}$} \\
\hline
\end{tabular}


TABLE LXI

IMAA VALUES, EQUIVALENT DEPTHS, DEPTH IN FLOW, ELEVATION OF SAMPLES FROM SAMPLE SET GROUSE CREEK (GC)

\begin{tabular}{|c|c|c|c|c|c|}
\hline $\begin{array}{l}\text { SAMPLE } \\
\text { LABELS }\end{array}$ & $\begin{array}{l}\text { \#DEPTH } \\
\text { IN FLOW }\end{array}$ & $\begin{array}{l}\text { SELEVATION } \\
\text { IN FLOW }\end{array}$ & LA & CE & SM \\
\hline $\begin{array}{l}8.21 \# 1 c c \\
8-21 \# 2 c \\
8-21 \# 3 c \\
8-21 \# 4 C \\
8-21 \# 5 c\end{array}$ & $\begin{array}{r}8(100) 170.00 \\
(98) 165.00 \\
(83) 142.00 \\
(67) 115.00 \\
(19) 33.00\end{array}$ & $\begin{array}{l}1784 \\
1787 \\
1814 \\
1841 \\
1923\end{array}$ & $\begin{array}{l}33.00 \\
31.80 \\
29.50 \\
30.30 \\
29.40\end{array}$ & $\begin{array}{l}68.00 \\
68.00 \\
65.00 \\
63.00 \\
61.00\end{array}$ & $\begin{array}{l}8.47 \\
8.26 \\
7.83 \\
7.76 \\
7.66\end{array}$ \\
\hline LABELS & & & EU & TB & $Y 8$ \\
\hline $\begin{array}{l}8-21 \# 1 c c \\
8-21 \# 2 c \\
8 \cdot 21 \# 3 c \\
8-21 \# 4 c \\
8 \cdot 21 \# 5 c\end{array}$ & & & $\begin{array}{l}2.59 \\
2.61 \\
2.34 \\
2.41 \\
2.28\end{array}$ & $\begin{array}{l}1.50 \\
1.70 \\
1.50 \\
1.40 \\
1.60\end{array}$ & $\begin{array}{l}4.20 \\
5.60 \\
4.10 \\
4.80 \\
5.40\end{array}$ \\
\hline LABELS & & & LU & $B A$ & Co \\
\hline $\begin{array}{l}8-21 \# 1 c c \\
8-21 \# 2 c \\
8-21 \# 3 c \\
8-21 \# 4 c \\
8-21 \# 5 c\end{array}$ & & & $\begin{array}{l}0.46 \\
0.62 \\
0.57 \\
0.57 \\
0.61\end{array}$ & $\begin{array}{l}600.00 \\
540.00 \\
600.00 \\
630.00 \\
590.00\end{array}$ & $\begin{array}{l}15.00 \\
20.00 \\
29.00 \\
25.00 \\
28.00\end{array}$ \\
\hline LABELS & & & +FEO & $+K_{2} O$ & HF \\
\hline $\begin{array}{l}8 \cdot 21 \# 1 c c \\
8-21 \# 2 c \\
8-21 \# 3 c \\
8-21 \# 4 c \\
8-21 \# 5 c\end{array}$ & & & $\begin{array}{r}9.48 \\
11.65 \\
11.93 \\
12.08 \\
11.76\end{array}$ & $\begin{array}{l}2.70 \\
2.30 \\
2.00 \\
2.20 \\
1.90\end{array}$ & $\begin{array}{l}6.30 \\
6.30 \\
5.70 \\
6.10 \\
5.90\end{array}$ \\
\hline LABELS & & & $+\mathrm{HA}_{2} \mathrm{O}$ & $R B$ & sc \\
\hline $\begin{array}{l}8 \cdot 21 \# 1 C c \\
8 \cdot 21 \# 2 c \\
8 \cdot 21 \# 3 C \\
8 \cdot 21 \# 4 C \\
8 \cdot 21 \# 5 C\end{array}$ & & & $\begin{array}{l}3.45 \\
3.51 \\
3.47 \\
3.47 \\
3.47\end{array}$ & $\begin{array}{l}90.00 \\
64.00 \\
54.00 \\
41.00 \\
48.00\end{array}$ & $\begin{array}{l}32.77 \\
32.20 \\
32.47 \\
33.17 \\
33.32\end{array}$ \\
\hline LABELS & & & TA & TH & \\
\hline $\begin{array}{l}8-21 \# 1 C C \\
8-21 \# 2 C \\
8 \cdot 21 \# 3 C \\
8 \cdot 21 \# 4 C \\
8-21 \# 5 C\end{array}$ & & & $\begin{array}{l}0.52 \\
0.49 \\
0.43 \\
0.51 \\
0.34\end{array}$ & $\begin{array}{l}6.30 \\
6.10 \\
6.70 \\
6.80 \\
6.90\end{array}$ & \\
\hline \multicolumn{6}{|c|}{$\begin{array}{l}\text { \&(xx) enclose equivalent depths used to compare concentrations against another sample set } \\
\text { in a hypothetical flow of } 100 \text { feet thick. } \\
\text { - Depth in flow is calculated from field elevations during measurement of stratigraphic } \\
\text { section } \\
\text { s Elevation of the sample with in the flow was measured during stratigraphic section or } \\
\text { traverse measurements } \\
+ \text { Oxides concentrations in weight percent (iron is in total feo) and remaining } \\
\text { concentrations in part per million }\end{array}$} \\
\hline
\end{tabular}


TABLE LXII

INAA VALUES, EQUIVALENT DEPTHS, DEPTH IN FLOH, ELEVATION OF

SAMPLES FROM SAMPLE SET WENAHA RAVINE (UR)

\begin{tabular}{|c|c|c|c|c|c|}
\hline $\begin{array}{l}\text { SAMPLE } \\
\text { LABELS }\end{array}$ & $\begin{array}{l}\text { \#DEPTH } \\
\text { IN FLOU }\end{array}$ & $\begin{array}{l}\text { SELEVATION } \\
\text { IN FLOW }\end{array}$ & LA & CE & SM \\
\hline $\begin{array}{l}8 \cdot 22 \# 1 C \\
M \\
M 1 \\
M 2 \\
M 3 \\
M 4 \\
N \\
8 \cdot 22 \# 3 C \\
8 \cdot 22 \# 4 C \\
M C 4 D\end{array}$ & $\begin{array}{r}8(98) 284.00 \\
(83) 235.00 \\
(81) 230.00 \\
(80) 228.00 \\
(78) 221.00 \\
(76) 214.00 \\
(73) 206.00 \\
(36) 92.00 \\
(30) 85.00 \\
(6) 0.00\end{array}$ & $\begin{array}{l}1830 \\
1879 \\
1884 \\
1886 \\
1893 \\
1900 \\
1908 \\
2022 \\
2029 \\
2114\end{array}$ & $\begin{array}{l}32.30 \\
31.60 \\
31.00 \\
32.70 \\
32.30 \\
31.80 \\
37.30 \\
30.60 \\
31.90 \\
30.10\end{array}$ & $\begin{array}{l}65.00 \\
69.00 \\
66.00 \\
67.00 \\
64.00 \\
68.00 \\
66.00 \\
62.00 \\
64.00 \\
63.00\end{array}$ & $\begin{array}{r}8.53 \\
8.63 \\
8.30 \\
8.47 \\
8.19 \\
8.27 \\
10.10 \\
8.05 \\
8.25 \\
7.71\end{array}$ \\
\hline LABELS & & & EU & TB & YB \\
\hline $\begin{array}{l}8-22 \# 1 C \\
M \\
M 1 \\
M 2 \\
M 3 \\
M 4 \\
N \\
8 \cdot 22 \# 3 C \\
8 \cdot 22 \# 4 C \\
M C 40\end{array}$ & & & $\begin{array}{l}2.67 \\
2.65 \\
2.63 \\
2.55 \\
2.49 \\
2.50 \\
2.88 \\
2.47 \\
2.49 \\
2.48\end{array}$ & $\begin{array}{l}1.80 \\
1.80 \\
1.50 \\
1.50 \\
1.70 \\
1.60 \\
2.20 \\
1.50 \\
1.60 \\
1.60\end{array}$ & $\begin{array}{l}5.50 \\
5.50 \\
5.00 \\
5.90 \\
4.60 \\
5.80 \\
5.60 \\
5.10 \\
6.00 \\
4.00\end{array}$ \\
\hline LABELS & & & LU & $B A$ & co \\
\hline $\begin{array}{l}8 \cdot 22 \# 1 C \\
M \\
M 1 \\
M 2 \\
M 3 \\
M 4 \\
N \\
8 \cdot 22 \# 3 C \\
8 \cdot 22 \# 4 C \\
M C 4 D\end{array}$ & & & $\begin{array}{l}0.62 \\
0.57 \\
0.58 \\
0.74 \\
0.60 \\
0.59 \\
0.71 \\
0.55 \\
0.61 \\
0.55\end{array}$ & $\begin{array}{l}640.00 \\
570.00 \\
590.00 \\
680.00 \\
620.00 \\
630.00 \\
750.00 \\
550.00 \\
640.00 \\
540.00\end{array}$ & $\begin{array}{l}14.00 \\
13.00 \\
25.00 \\
20.00 \\
16.00 \\
20.00 \\
19.00 \\
25.00 \\
23.00 \\
27.00\end{array}$ \\
\hline \multicolumn{6}{|c|}{$\begin{array}{l}\text { (xx) enclose equivalent depths used to compare concentrations against another sample s } \\
\text { in a hypothetical flow of } 100 \text { feet thick. } \\
\text { * Depth in flow is calculated from field elevations during measurement of stratigraphic } \\
\text { section } \\
\text { s Elevation of the sample within the flow was measured during stratigraphic section or } \\
\text { traverse measurements } \\
+ \text { Oxides concentrations in weight percent (iron is in total } F e 0 \text { ) and remaining } \\
\text { concentrations in part per million }\end{array}$} \\
\hline
\end{tabular}


TABLE LXII CONTINUED

INAA VALUES, EQUIVALENT DEPTHS, DEPTH IN FLOW, ELEVATION OF

SAMPLES FROM SAMPLE SET HENAHA RAVINE (UR)

\begin{tabular}{|c|c|c|c|}
\hline LABELS & +FEO & $+K_{2} O$ & HF \\
\hline $\begin{array}{l}8-22 \# 1 C \\
M \\
M 1 \\
M 2 \\
M 3 \\
M 4 \\
M \\
8-22 \# 3 C \\
8 \cdot 22 \# 4 C \\
M C 4 D\end{array}$ & $\begin{array}{l}11.56 \\
10.45 \\
11.82 \\
11.29 \\
11.16 \\
11.49 \\
10.67 \\
11.03 \\
11.30 \\
11.60\end{array}$ & $\begin{array}{l}2.50 \\
2.30 \\
2.40 \\
2.30 \\
2.00 \\
1.90 \\
2.30 \\
1.80 \\
2.80 \\
2.00\end{array}$ & $\begin{array}{l}6.50 \\
6.40 \\
6.60 \\
6.50 \\
6.00 \\
6.30 \\
6.60 \\
6.20 \\
6.20 \\
5.90\end{array}$ \\
\hline LABELS & $+\mathrm{HA}_{2} \mathrm{O}$ & RB & SC \\
\hline $\begin{array}{l}8-22 \# 1 C \\
M \\
M 1 \\
M 2 \\
M 3 \\
M 4 \\
M \\
8 \cdot 22 \# 3 C \\
8-22 \# 4 C \\
M C 4 D\end{array}$ & $\begin{array}{l}3.49 \\
3.59 \\
3.57 \\
3.48 \\
3.45 \\
3.53 \\
3.23 \\
3.56 \\
3.61 \\
3.27\end{array}$ & $\begin{array}{l}48.00 \\
54.00 \\
40.00 \\
52.00 \\
69.00 \\
58.00 \\
68.00 \\
53.00 \\
70.00 \\
42.00\end{array}$ & $\begin{array}{l}31.96 \\
33.06 \\
26.41 \\
31.66 \\
30.72 \\
30.81 \\
31.95 \\
32.28 \\
31.61 \\
32.46\end{array}$ \\
\hline LABELS & TA & TH & \\
\hline $\begin{array}{l}8-22 \# 1 C \\
M \\
M 1 \\
M 2 \\
M 3 \\
M 4 \\
N \\
8-22 \# 3 C \\
8-22 \# 4 C \\
M C 4 D\end{array}$ & $\begin{array}{l}0.50 \\
0.54 \\
0.55 \\
0.51 \\
0.36 \\
0.54 \\
0.53 \\
0.49 \\
0.49 \\
0.46\end{array}$ & $\begin{array}{l}6.40 \\
6.40 \\
6.70 \\
6.80 \\
6.50 \\
6.20 \\
6.70 \\
6.30 \\
6.90 \\
6.60\end{array}$ & \\
\hline \multicolumn{4}{|c|}{$\begin{array}{l}\text { \&(xx) enclose equivalent depths used to compare concentrations against another sample set } \\
\text { in a hypothetical flow of } 100 \text { feet thick. } \\
\text { * Depth in flow is calculated from field elevations during measurement of stratigraphic } \\
\text { section } \\
\text { \$ Elevation of the sample within the flow was measured during stratigraphic section or } \\
\text { traverse measurements } \\
+ \text { Oxides concentrations in weight percent (iron is in total feo) and remaining } \\
\text { concentrations in part per million }\end{array}$} \\
\hline
\end{tabular}


TABLE LXIII

INAA VALUES, EQUIVALENT DEPTHS, DEPTH IN FLON, ELEVATION OF SAMPLES FROM SAMPLE SET WENAHA RAVINE (UR)

\begin{tabular}{|c|c|c|c|c|c|}
\hline $\begin{array}{l}\text { SAMPLE } \\
\text { LABELS }\end{array}$ & $\begin{array}{l}\text { ॠDEPTH } \\
\text { IN FLON }\end{array}$ & $\begin{array}{l}\text { SELEVATION } \\
\text { IN FLON }\end{array}$ & LA & CE & SM \\
\hline $\begin{array}{l}8-22-T 1 A 1 \\
8-22-T 1 A 1 R \\
8-22-T 1 A 2 \\
8-22-T 1 A 3 \\
8-22-T 1 B \\
8-22-T 1 C\end{array}$ & $\begin{array}{l}1.00 \\
2.00 \\
3.00 \\
4.00 \\
5.00 \\
6.00\end{array}$ & $\begin{array}{l}2200 \\
2199 \\
2198 \\
2197 \\
2196 \\
2195\end{array}$ & $\begin{array}{l}30.40 \\
31.40 \\
30.90 \\
31.40 \\
30.20 \\
30.50\end{array}$ & $\begin{array}{l}62.00 \\
63.00 \\
65.00 \\
61.00 \\
65.00 \\
62.00\end{array}$ & $\begin{array}{l}7.71 \\
7.80 \\
7.97 \\
8.04 \\
7.87 \\
7.77\end{array}$ \\
\hline LABELS & & & EU & TB & YB \\
\hline $\begin{array}{l}8-22-T 1 A 1 \\
8-22-T 1 A 1 R \\
8-22-T 1 A 2 \\
8-22-T 1 A 3 \\
8-22-T 1 B \\
8-22-T 1 C\end{array}$ & & & $\begin{array}{l}2.31 \\
2.33 \\
2.45 \\
2.39 \\
2.45 \\
2.44\end{array}$ & $\begin{array}{l}1.60 \\
1.40 \\
1.80 \\
1.60 \\
1.40 \\
1.60\end{array}$ & $\begin{array}{l}4.50 \\
4.50 \\
5.20 \\
5.20 \\
5.10 \\
4.90\end{array}$ \\
\hline LABELS & & & LU & BA & $\mathrm{CO}$ \\
\hline $\begin{array}{l}8-22-T 1 A 1 \\
8-22-T 1 A 1 R \\
8-22-T 1 A 2 \\
8-22-T 1 A 3 \\
8-22-T 1 B \\
8-22-T 1 C\end{array}$ & & & $\begin{array}{l}0.56 \\
0.63 \\
0.54 \\
0.60 \\
0.68 \\
0.56\end{array}$ & $\begin{array}{l}500.00 \\
640.00 \\
630.00 \\
720.00 \\
660.00 \\
550.00\end{array}$ & $\begin{array}{l}19.00 \\
20.00 \\
23.00 \\
30.00 \\
17.00 \\
24.00\end{array}$ \\
\hline \multicolumn{6}{|c|}{$\begin{array}{l}(x x) \text { enclose equivalent depths used to compare values against another sample set in a } \\
\text { hypothetical flow of } 100 \text { feet thick. } \\
\text { - Depth in flow was not measured for this sample set. } \\
\text { Elevation of the sample within the flow was measured during stratigraphic section or } \\
\text { traverse measurements } \\
+ \text { Oxides concentrations in weight percent (iron is in total feo) and remaining } \\
\text { concentrations in part per million }\end{array}$} \\
\hline
\end{tabular}


TABLE LXIII CONTINUED

INAA VALUES, EQUiVALENT DEPTHS, DEPTH IN FLOW, ELEVATION OF

SAMPLES FROM SAMPLE SET WENAHA RAVINE (WR)

\begin{tabular}{|c|c|c|c|}
\hline LABELS & +FEO & $+K_{2} O$ & HF \\
\hline $\begin{array}{l}8-22-T 1 A 1 \\
8-22-T 1 A 1 R \\
8-22-T 1 A 2 \\
8-22-T 1 A 3 \\
8-22-T 1 B \\
8-22-T 1 C\end{array}$ & $\begin{array}{l}11.52 \\
11.39 \\
11.78 \\
11.01 \\
11.27 \\
10.56\end{array}$ & $\begin{array}{l}2.60 \\
2.40 \\
2.20 \\
2.60 \\
2.00 \\
2.10\end{array}$ & $\begin{array}{l}5.80 \\
5.70 \\
6.40 \\
5.80 \\
6.00 \\
5.70\end{array}$ \\
\hline LABELS & $+\mathrm{NA}_{2} \mathrm{O}$ & RB & SC \\
\hline $\begin{array}{l}8-22-T 1 A 1 \\
8-22-T 1 A 1 R \\
8-22-T 1 A 2 \\
8-22-T 1 A 3 \\
8-22-T 1 B \\
8-22-T 1 C\end{array}$ & $\begin{array}{l}3.48 \\
3.75 \\
3.45 \\
3.47 \\
3.47 \\
3.32\end{array}$ & $\begin{array}{l}59.00 \\
54.00 \\
66.00 \\
56.00 \\
66.00 \\
39.00\end{array}$ & $\begin{array}{l}30.07 \\
30.20 \\
31.80 \\
25.05 \\
31.18 \\
30.19\end{array}$ \\
\hline LABELS & TA & TH & \\
\hline $\begin{array}{l}8 \cdot 22-T 1 A T \\
8-22-T 1 A 1 R \\
8-22-T 1 A 2 \\
8-22 \cdot T 1 A 3 \\
8-22-T 1 B \\
8-22-T 1 C\end{array}$ & $\begin{array}{l}0.46 \\
0.52 \\
0.51 \\
0.37 \\
0.48 \\
0.47\end{array}$ & $\begin{array}{l}6.60 \\
6.20 \\
7.10 \\
6.40 \\
6.80 \\
6.50\end{array}$ & \\
\hline \multicolumn{4}{|c|}{$\begin{array}{l}8(x x) \text { enclose equivalent depths used to compare values against another sample set in a } \\
\text { hypothetical flow of } 100 \text { feet thick. } \\
\text { * Depth in flow was not measured for this sample set. } \\
\text { s Elevation of the sample within the flow was measured during stratigraphic section or } \\
\text { traverse measurements } \\
+ \text { Oxides concentrations in weight percent (iron is in total feo) and remaining } \\
\text { concentrations in part per million }\end{array}$} \\
\hline
\end{tabular}


TABLE LXIV

inaA Values, equivalent Depths, Depth in FLOW, Elevation of SAMPLES FROM SAMPLE SET WENAHA RAVINE (WR)

\begin{tabular}{|c|c|c|c|c|c|}
\hline $\begin{array}{l}\text { SAMPLE } \\
\text { LABELS }\end{array}$ & $\begin{array}{c}\text { *DEPTH } \\
\text { IN FLOH }\end{array}$ & $\begin{array}{l}\text { SELEVATION } \\
\text { IN FLON }\end{array}$ & LA & $\mathrm{CE}$ & SM \\
\hline $\begin{array}{l}8 \cdot 20 \# 1 \\
8 \cdot 20 \# 2 \\
8 \cdot 20 \# 5 \\
8 \cdot 20 \# 4 \\
8 \cdot 20 \# 3\end{array}$ & $\begin{array}{l}\&(6) 325.00 \\
(15) 300.00 \\
(20) 290.00 \\
(25) 240.00 \\
(30) 250.00\end{array}$ & $\begin{array}{l}2158 \\
2133 \\
2123 \\
2073 \\
2083\end{array}$ & $\begin{array}{l}32.30 \\
30.50 \\
31.50 \\
31.90 \\
31.40\end{array}$ & $\begin{array}{l}68.00 \\
62.00 \\
63.00 \\
62.00 \\
64.00\end{array}$ & $\begin{array}{l}8.15 \\
8.00 \\
8.08 \\
8.10 \\
8.09\end{array}$ \\
\hline LABELS & & & EU & $T B$ & YB \\
\hline $\begin{array}{l}8-20 \# 1 \\
8-20 \# 2 \\
8-20 \# 5 \\
8-20 \# 4 \\
8-20 \# 3\end{array}$ & 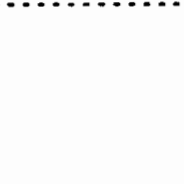 & . & $\begin{array}{l}2.44 \\
2.44 \\
2.42 \\
2.39 \\
2.46\end{array}$ & $\begin{array}{l}1.60 \\
1.60 \\
1.40 \\
1.70 \\
1.70\end{array}$ & $\begin{array}{l}5.90 \\
5.70 \\
5.10 \\
6.10 \\
4.80\end{array}$ \\
\hline LABELS & & & LU & BA & co \\
\hline $\begin{array}{l}8-20 \# 1 \\
8-20 \# 2 \\
8-20 \# 5 \\
8-20 \# 4 \\
8-20 \# 3\end{array}$ & & & $\begin{array}{l}0.55 \\
0.52 \\
0.54 \\
0.60 \\
0.53\end{array}$ & $\begin{array}{l}570.00 \\
610.00 \\
570.00 \\
490.00 \\
610.00\end{array}$ & $\begin{array}{l}32.00 \\
29.00 \\
20.00 \\
17.00 \\
16.00\end{array}$ \\
\hline LABELS & & & +FEO & $+K_{2} O$ & HF \\
\hline $\begin{array}{l}8 \cdot 20 \# 1 \\
8 \cdot 20 \# 2 \\
8 \cdot 20 \# 5 \\
8 \cdot 20 \# 4 \\
8 \cdot 20 \# 3\end{array}$ & & & $\begin{array}{l}11.07 \\
11.62 \\
11.68 \\
10.89 \\
11.06\end{array}$ & $\begin{array}{l}1.90 \\
2.30 \\
2.10 \\
2.20 \\
2.30\end{array}$ & $\begin{array}{l}6.60 \\
6.10 \\
6.40 \\
5.70 \\
6.40\end{array}$ \\
\hline LABELS & & & $+\mathrm{NA}_{2} \mathrm{O}$ & RB & SC \\
\hline $\begin{array}{l}8 \cdot 20 \# 1 \\
8 \cdot 20 \# 2 \\
8 \cdot 20 \# 5 \\
8-20 \# 4 \\
8 \cdot 20 \# 3\end{array}$ & & & $\begin{array}{l}3.22 \\
3.41 \\
3.28 \\
3.37 \\
3.47\end{array}$ & $\begin{array}{l}41.00 \\
47.00 \\
64.00 \\
46.00 \\
49.00\end{array}$ & $\begin{array}{l}31.45 \\
31.83 \\
31.84 \\
29.00 \\
32.77\end{array}$ \\
\hline LABELS & & & TA & TH & \\
\hline $\begin{array}{l}8 \cdot 20 \# 1 \\
8 \cdot 20 \# 2 \\
8 \cdot 20 \# 5 \\
8-20 \# 4 \\
8 \cdot 20 \# 3\end{array}$ & & & $\begin{array}{l}0.61 \\
0.49 \\
0.55 \\
0.47 \\
0.54\end{array}$ & $\begin{array}{l}7.10 \\
7.00 \\
6.90 \\
6.20 \\
7.20\end{array}$ & \\
\hline
\end{tabular}

$\overline{G(x x)}$ enclose equivalent depths used to compare values against another sample set in a hypothetical flow of 100 feet thick.

* Depth in flow was not measured for this sample set.

S Elevation of the sample within the flow was measured during stratigraphic section or traverse measurements

+ Oxides concentrations in weight percent (iron is in total feO) and remaining concentrations in part per million 
TABLE LXV

INAA VALUES, EOUIVALENT DEPTHS, DEPTH IN FLOW, ELEVATION OF

SAMPLES FROM SAMPLE SET UENAHA RAVINE (UR)

\begin{tabular}{|c|c|c|c|c|c|}
\hline $\begin{array}{l}\text { SAMPLE } \\
\text { LABELS }\end{array}$ & $\begin{array}{l}\text { DEPTH } \\
\text { IN FLOW }\end{array}$ & $\begin{array}{l}\text { SELEVATION } \\
\text { IN FLOW }\end{array}$ & LA & CE & SM \\
\hline $\begin{array}{l}8-22-S C H 1 \\
8-22 \cdot S C H 2 \\
8-22-S C \# 2 B \\
8-22-S C \# 3 \\
8-20-S C \# 4\end{array}$ & $\begin{array}{r}(33) 82.00 \\
(30) 72.00 \\
(28) 71.50 \\
(25) 71.00 \\
(6) 0.00\end{array}$ & $\begin{array}{l}2087 \\
2097 \\
2097.5 \\
2098 \\
2169\end{array}$ & $\begin{array}{l}26.90 \\
26.60 \\
25.80 \\
24.00 \\
26.40\end{array}$ & $\begin{array}{l}58.00 \\
56.00 \\
52.00 \\
50.00 \\
56.00\end{array}$ & $\begin{array}{l}7.18 \\
6.83 \\
7.08 \\
6.38 \\
7.10\end{array}$ \\
\hline
\end{tabular}

\begin{tabular}{|c|c|c|c|}
\hline LABELS & EU & TB & YB \\
\hline $\begin{array}{l}8-22-S C \# 1 \\
8-22 \cdot S C \# 2 \\
8-22-S C \# 2 B \\
8-22-S C \# 3 \\
8-20-S C \# 4\end{array}$ & $\begin{array}{l}2.32 \\
2.24 \\
2.30 \\
2.01 \\
2.38\end{array}$ & $\begin{array}{l}1.50 \\
1.40 \\
1.20 \\
1.20 \\
1.30\end{array}$ & $\begin{array}{l}5.00 \\
6.10 \\
4.70 \\
4.20 \\
4.90\end{array}$ \\
\hline
\end{tabular}

LABELS

\begin{tabular}{|c|c|c|c|}
\hline $\begin{array}{l}8-22-s C \# 1 \\
8-22-s C \# 2 \\
8-22-s C \# 2 B \\
8-22-S C \# 3 \\
8-20-s C \# 4\end{array}$ & $\begin{array}{l}0.54 \\
0.53 \\
0.59 \\
0.45 \\
0.53\end{array}$ & $\begin{array}{l}550.00 \\
480.00 \\
660.00 \\
470.00 \\
610.00\end{array}$ & $\begin{array}{l}28.00 \\
24.00 \\
25.00 \\
20.00 \\
27.00\end{array}$ \\
\hline
\end{tabular}

\begin{tabular}{|c|c|c|c|}
\hline LABELS & +FEO & $+K_{2} \mathrm{O}$ & HF \\
\hline $\begin{array}{l}8-22-S C \# 1 \\
8-22-S C H 2 \\
8-22-S C \# 2 B \\
8-22 \cdot S C \# 3 \\
8-20-S C \# 4\end{array}$ & $\begin{array}{l}12.45 \\
12.12 \\
12.73 \\
10.89 \\
11.77\end{array}$ & $\begin{array}{l}1.80 \\
1.80 \\
1.70 \\
1.80 \\
2.00\end{array}$ & $\begin{array}{l}5.20 \\
5.20 \\
5.20 \\
5.10 \\
5.40\end{array}$ \\
\hline LABELS & $+\mathrm{NA}_{2} \mathrm{O}$ & RB & sc \\
\hline $\begin{array}{l}8 \cdot 22 \cdot S C \# 1 \\
8 \cdot 22 \cdot S C \# 2 \\
8 \cdot 22 \cdot S C \# 2 B \\
8 \cdot 22 \cdot S C \# 3 \\
8 \cdot 20 \cdot S C \# 4\end{array}$ & $\begin{array}{l}3.44 \\
4.21 \\
3.07 \\
3.09 \\
2.98\end{array}$ & $\begin{array}{l}47.00 \\
47.00 \\
32.00 \\
42.00 \\
60.00\end{array}$ & $\begin{array}{l}36.32 \\
33.19 \\
34.98 \\
31.76 \\
34.71\end{array}$ \\
\hline
\end{tabular}

\begin{tabular}{|c|c|c|}
\hline LABELS & TA & TH \\
\hline $\begin{array}{l}8-22-s C \# 1 \\
8-22-s C \# 2 \\
8-22-s C \# 2 B \\
8-22-s C \# 3 \\
8-20-s C \# 4\end{array}$ & $\begin{array}{l}0.49 \\
0.44 \\
0.51 \\
0.29 \\
0.51\end{array}$ & $\begin{array}{l}5.70 \\
5.20 \\
5.30 \\
5.40 \\
5.60\end{array}$ \\
\hline
\end{tabular}

$\&(x x)$ enclose equivalent depths used to compare values against another sample set in a hypothetical flow of 100 feet thick.

- Depth in flow was not measured for this sample set.

s Elevation of the sample within the flow was measured during stratigraphic section or traverse measurements

+ Oxides concentrations in weight percent (iron is in total feo) and remaining concentrations in part per million 


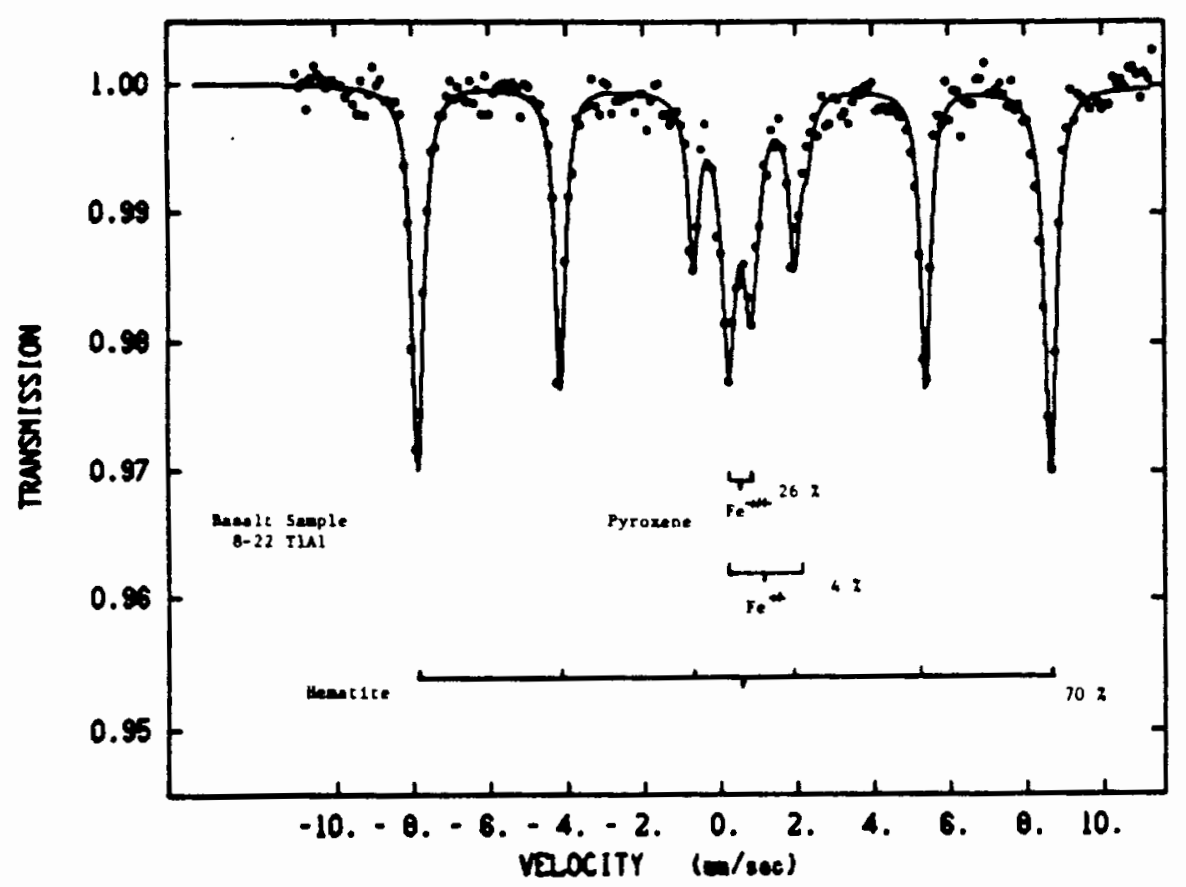

Figure 55. Mossbauer spectrum of sample 8-22-T1A1. The minerals containing ferric and ferrous iron are indicated on the spectrum with their appropriate percentage of the sample. 


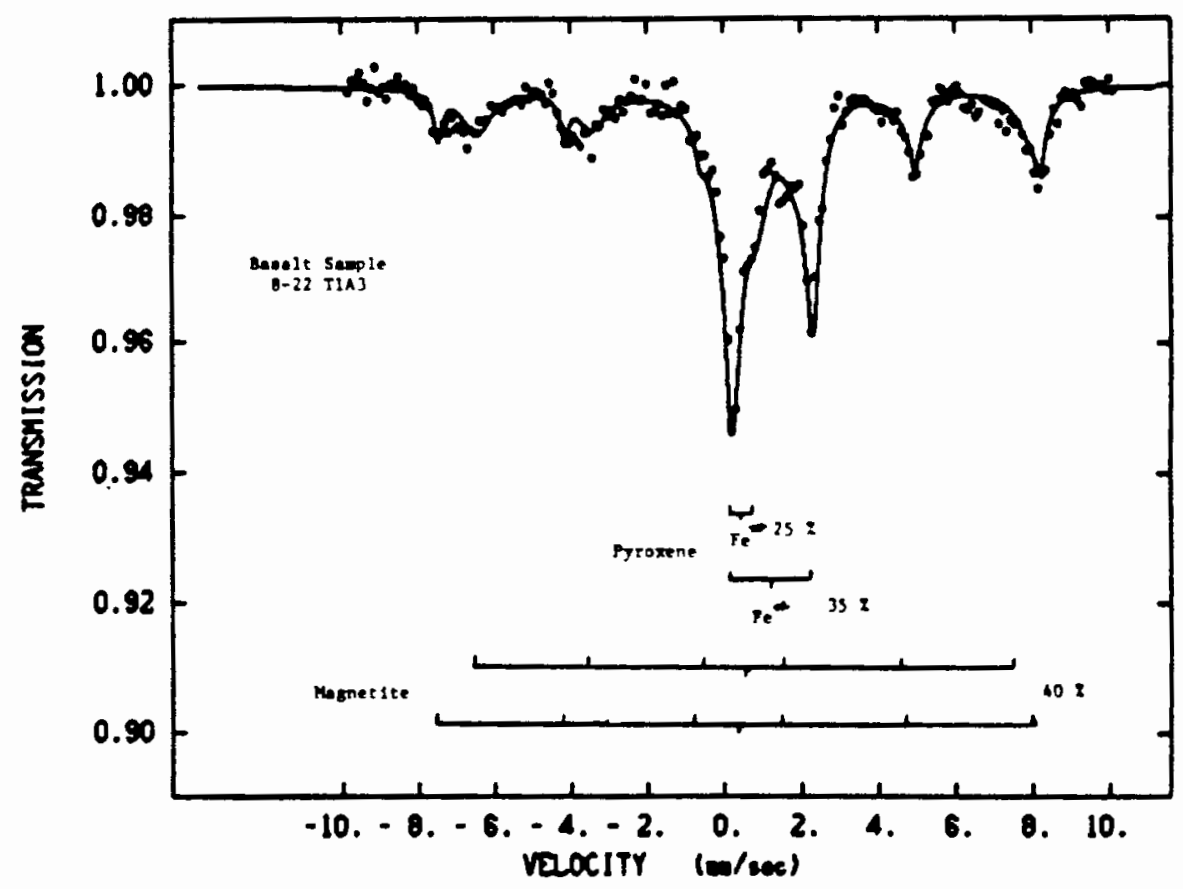

Figure 56. Mossbauer spectrum of sample 8-22-T1A3. The minerals containing ferric and ferrous iron are indicated on the spectrum with their appropriate percentage of the sample. 


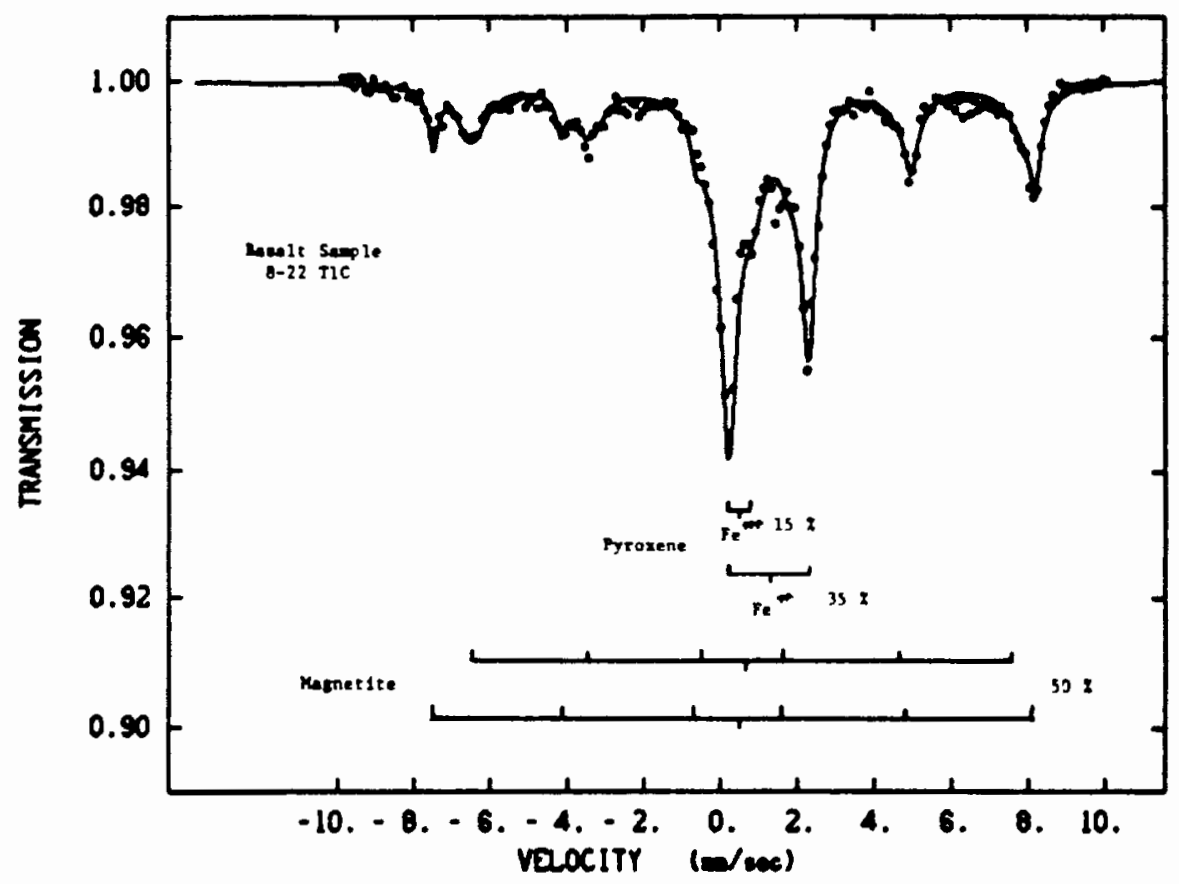

Figure 57. Mossbauer spectrum of sample 8-22-T1C.

The minerals containing ferric and ferrous iron are indicated on the spectrum with their appropriate percentage of the sample. 
TABLE LVI

INMA DATA FROM 1ST COUNT FOR CERTAIN ELEMENTS FOLLOWED BY ITS ERROR

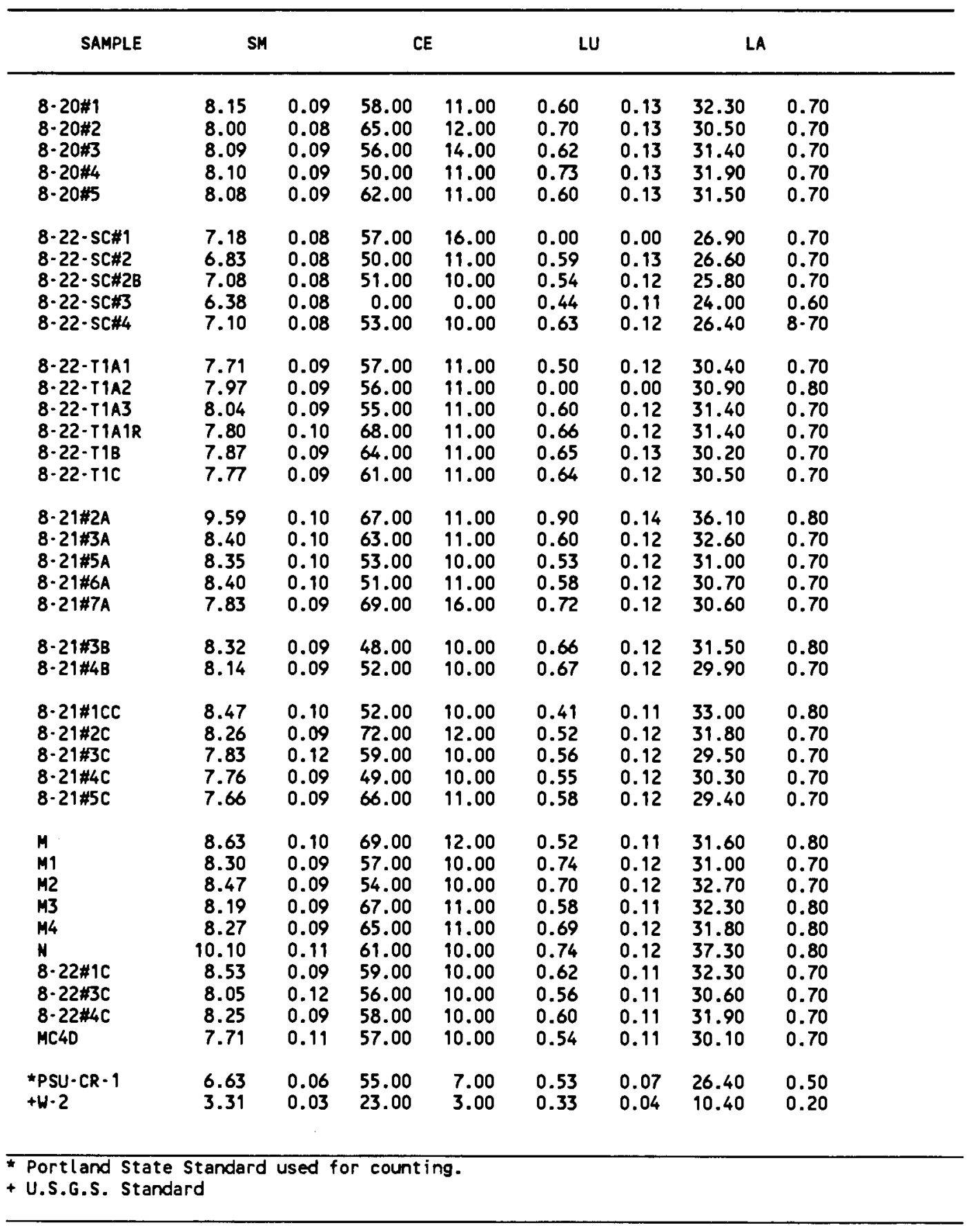


TABLE LXVI CONTINUED

INNA DATA FROM IST COUNT FOR CERTAIN ELEMENTS FOLLOWED BY ITS ERROR

\begin{tabular}{|c|c|c|c|c|c|c|c|c|}
\hline \multirow{2}{*}{$\begin{array}{l}\text { SAMPLE } \\
8-20 \# 1 \\
8-20 \# 2 \\
8-20 \# 3 \\
8-20 \# 4 \\
8-20 \# 5\end{array}$} & \multicolumn{2}{|c|}{ SC } & \multicolumn{2}{|c|}{ FE } & \multicolumn{2}{|c|}{ Co } & \multicolumn{2}{|c|}{$N A$} \\
\hline & $\begin{array}{l}31.10 \\
30.90 \\
32.20 \\
28.90 \\
31.60\end{array}$ & $\begin{array}{l}0.50 \\
0.40 \\
0.40 \\
0.40 \\
0.40\end{array}$ & $\begin{array}{l}11.20 \\
11.20 \\
10.40 \\
10.30 \\
11.50\end{array}$ & $\begin{array}{l}0.50 \\
0.50 \\
0.50 \\
0.40 \\
0.50\end{array}$ & $\begin{array}{l}32.00 \\
29.00 \\
16.00 \\
17.00 \\
20.00\end{array}$ & $\begin{array}{l}4.00 \\
4.00 \\
4.00 \\
4.00 \\
4.00\end{array}$ & $\begin{array}{l}3.22 \\
3.49 \\
3.47 \\
3.37 \\
3.28\end{array}$ & $\begin{array}{l}0.01 \\
0.01 \\
0.01 \\
0.01 \\
0.01\end{array}$ \\
\hline $\begin{array}{l}8 \cdot 22-S C \# 1 \\
8-22-S C \# 2 \\
8 \cdot 22-s C \# 2 B \\
8-22 \cdot S C \# 3 \\
8-22-s C \# 4\end{array}$ & $\begin{array}{l}35.50 \\
32.50 \\
34.00 \\
31.00 \\
34.30\end{array}$ & $\begin{array}{l}0.40 \\
0.40 \\
0.40 \\
0.40 \\
0.40\end{array}$ & $\begin{array}{l}12.30 \\
11.70 \\
12.00 \\
10.90 \\
12.00\end{array}$ & $\begin{array}{l}0.40 \\
0.50 \\
0.40 \\
0.40 \\
0.40\end{array}$ & $\begin{array}{l}28.00 \\
24.00 \\
25.00 \\
20.00 \\
27.00\end{array}$ & $\begin{array}{l}4.00 \\
4.00 \\
4.00 \\
4.00 \\
4.00\end{array}$ & $\begin{array}{l}3.44 \\
4.21 \\
3.07 \\
3.09 \\
2.98\end{array}$ & $\begin{array}{l}0.01 \\
0.01 \\
0.01 \\
0.01 \\
0.01\end{array}$ \\
\hline $\begin{array}{l}8 \cdot 22-T_{1 A 1} \\
8-22-T_{1 A 2} \\
8 \cdot 22-T_{1 A 3} \\
8-22 \cdot T_{1 A 1 R} \\
8 \cdot 22-T_{1} \\
8-22-T_{1} \mathrm{C}\end{array}$ & $\begin{array}{l}30.60 \\
31.00 \\
31.00 \\
29.90 \\
30.40 \\
30.20\end{array}$ & $\begin{array}{l}0.40 \\
0.40 \\
0.40 \\
0.40 \\
0.50 \\
0.40\end{array}$ & $\begin{array}{l}11.70 \\
11.60 \\
10.70 \\
11.20 \\
10.60 \\
10.70\end{array}$ & $\begin{array}{l}0.40 \\
0.40 \\
0.40 \\
0.40 \\
0.40 \\
0.40\end{array}$ & $\begin{array}{l}19.00 \\
23.00 \\
30.00 \\
20.00 \\
17.00 \\
24.00\end{array}$ & $\begin{array}{l}4.00 \\
5.00 \\
4.00 \\
3.00 \\
4.00 \\
5.00\end{array}$ & $\begin{array}{l}3.48 \\
3.45 \\
3.47 \\
3.75 \\
3.47 \\
3.32\end{array}$ & $\begin{array}{l}0.01 \\
0.01 \\
0.01 \\
0.01 \\
0.01 \\
0.01\end{array}$ \\
\hline $\begin{array}{l}8-21 \# 2 A \\
8-21 \# 3 A \\
8-21 \# 5 A \\
8 \cdot 21 \# 6 A \\
8-21 \# 7 A\end{array}$ & $\begin{array}{l}34.40 \\
31.60 \\
31.80 \\
31.80 \\
31.20\end{array}$ & $\begin{array}{l}0.40 \\
0.40 \\
0.50 \\
0.40 \\
0.40\end{array}$ & $\begin{array}{r}8.50 \\
11.50 \\
11.00 \\
10.50 \\
11.20\end{array}$ & $\begin{array}{l}0.40 \\
0.40 \\
0.40 \\
0.40 \\
0.40\end{array}$ & $\begin{array}{r}0.00 \\
24.00 \\
22.00 \\
20.00 \\
19.00\end{array}$ & $\begin{array}{l}0.00 \\
4.00 \\
4.00 \\
4.00 \\
4.00\end{array}$ & $\begin{array}{l}3.69 \\
3.64 \\
3.52 \\
3.59 \\
3.48\end{array}$ & $\begin{array}{l}0.01 \\
0.01 \\
0.01 \\
0.01 \\
0.01\end{array}$ \\
\hline $\begin{array}{l}8-21 \# 3 B \\
8-21 \# 4 B\end{array}$ & $\begin{array}{l}31.50 \\
31.30\end{array}$ & $\begin{array}{l}0.40 \\
0.40\end{array}$ & $\begin{array}{l}10.90 \\
11.10\end{array}$ & $\begin{array}{l}0.40 \\
0.40\end{array}$ & $\begin{array}{l}26.00 \\
17.00\end{array}$ & $\begin{array}{l}4.00 \\
4.00\end{array}$ & $\begin{array}{l}3.52 \\
3.51\end{array}$ & $\begin{array}{l}0.01 \\
0.01\end{array}$ \\
\hline $\begin{array}{l}8-21 \# 1 C C \\
8-21 \# 2 C \\
8-21 \# 3 C \\
8-21 \# 4 C \\
8-21 \# 5 C\end{array}$ & $\begin{array}{l}32.50 \\
31.10 \\
30.70 \\
32.00 \\
32.30\end{array}$ & $\begin{array}{l}0.40 \\
0.40 \\
0.40 \\
0.50 \\
0.40\end{array}$ & $\begin{array}{r}9.30 \\
11.30 \\
11.20 \\
11.40 \\
11.40\end{array}$ & $\begin{array}{l}0.40 \\
0.40 \\
0.40 \\
0.40 \\
0.40\end{array}$ & $\begin{array}{l}15.00 \\
20.00 \\
29.00 \\
25.00 \\
28.00\end{array}$ & $\begin{array}{l}3.00 \\
5.00 \\
3.00 \\
3.00 \\
3.00\end{array}$ & $\begin{array}{l}3.45 \\
3.51 \\
3.47 \\
3.47 \\
3.47\end{array}$ & $\begin{array}{l}0.01 \\
0.01 \\
0.01 \\
0.01 \\
0.01\end{array}$ \\
\hline $\begin{array}{l}M \\
M 1 \\
M 2 \\
M 3 \\
M 4 \\
N \\
8-22 \# 1 C \\
8-22 \# 3 C \\
8 \cdot 22 \# 4 C \\
M C 4 D\end{array}$ & $\begin{array}{l}32.50 \\
31.10 \\
31.10 \\
30.10 \\
30.40 \\
32.00 \\
32.20 \\
32.30 \\
30.50 \\
31.40\end{array}$ & $\begin{array}{l}0.40 \\
0.50 \\
0.40 \\
0.40 \\
0.40 \\
0.40 \\
0.40 \\
0.40 \\
0.40 \\
0.40\end{array}$ & $\begin{array}{l}10.20 \\
11.70 \\
11.60 \\
11.00 \\
11.20 \\
10.70 \\
11.50 \\
10.40 \\
11.10 \\
11.80\end{array}$ & $\begin{array}{l}0.40 \\
0.40 \\
0.40 \\
0.40 \\
0.40 \\
0.40 \\
0.40 \\
0.40 \\
0.40 \\
0.40\end{array}$ & $\begin{array}{l}13.00 \\
25.00 \\
20.00 \\
16.00 \\
20.00 \\
19.00 \\
14.00 \\
25.00 \\
23.00 \\
27.00\end{array}$ & $\begin{array}{l}3.00 \\
4.00 \\
3.00 \\
3.00 \\
3.00 \\
3.00 \\
3.00 \\
4.00 \\
3.00 \\
3.00\end{array}$ & $\begin{array}{l}3.59 \\
3.57 \\
3.48 \\
3.45 \\
3.53 \\
3.23 \\
3.49 \\
3.56 \\
3.61 \\
3.27\end{array}$ & $\begin{array}{l}0.01 \\
0.01 \\
0.01 \\
0.01 \\
0.01 \\
0.01 \\
0.01 \\
0.01 \\
0.01 \\
0.01\end{array}$ \\
\hline $\begin{array}{l}* P S U-C R-1 \\
+H-2\end{array}$ & $\begin{array}{l}33.70 \\
35.70\end{array}$ & $\begin{array}{l}0.20 \\
0.15\end{array}$ & $\begin{array}{r}19.80 \\
9.03\end{array}$ & $\begin{array}{l}0.20 \\
0.14\end{array}$ & $\begin{array}{l}24.20 \\
43.10\end{array}$ & $\begin{array}{l}1.90 \\
1.20\end{array}$ & $\begin{array}{l}3.32 \\
2.20\end{array}$ & $\begin{array}{l}0.01 \\
0.00\end{array}$ \\
\hline
\end{tabular}


TABLE LXVI CONTINUED

INMA DATA FROM IST COUNT FOR CERTAIN ELEMENTS FOLLOWED BY ITS ERROR

\begin{tabular}{|c|c|c|}
\hline SAMPLE & K & \\
\hline $\begin{array}{l}8-20 \# 1 \\
8-20 \# 2 \\
8-20 * 3 \\
8-20 \# 4 \\
8-20 \# 5\end{array}$ & $\begin{array}{l}1.90 \\
2.30 \\
2.30 \\
2.20 \\
2.10\end{array}$ & $\begin{array}{l}0.30 \\
0.30 \\
0.40 \\
0.40 \\
0.40\end{array}$ \\
\hline $\begin{array}{l}8-22-S C \# 1 \\
8-22-S C \# 2 \\
8-22-S C \# 2 B \\
8-22-S C \# 3 \\
8-22-S C \# 4\end{array}$ & $\begin{array}{l}1.80 \\
1.80 \\
1.70 \\
1.80 \\
2.00\end{array}$ & $\begin{array}{l}0.30 \\
0.30 \\
0.30 \\
0.30 \\
0.40\end{array}$ \\
\hline $\begin{array}{l}8-22-T 1 A 1 \\
8-22-T 1 A 2 \\
8-22-T 1 A 3 \\
8-22-T 1 A 1 R \\
8-22-T 1 B \\
8-22-T 1 C\end{array}$ & $\begin{array}{l}2.60 \\
2.20 \\
2.60 \\
2.40 \\
2.00 \\
2.10\end{array}$ & $\begin{array}{l}0.40 \\
0.40 \\
0.40 \\
0.40 \\
0.30 \\
0.40\end{array}$ \\
\hline $\begin{array}{l}8 \cdot 21 \# 2 A \\
8-21 \# 3 A \\
8-21 \# 5 A \\
8 \cdot 21 \# 6 A \\
8-21 \# 7 A\end{array}$ & $\begin{array}{l}3.30 \\
1.60 \\
2.10 \\
2.50 \\
2.30\end{array}$ & $\begin{array}{l}0.50 \\
0.30 \\
0.40 \\
0.40 \\
0.40\end{array}$ \\
\hline $\begin{array}{l}8-21 \# 3 B \\
8-21 \# 4 B\end{array}$ & $\begin{array}{l}2.10 \\
2.30\end{array}$ & $\begin{array}{l}0.40 \\
0.40\end{array}$ \\
\hline $\begin{array}{l}8-21 \# 1 C C \\
8-21 \# 2 C \\
8-21 \# 3 C \\
8-21 \# 4 C \\
8-21 \# 5 C\end{array}$ & $\begin{array}{l}2.70 \\
2.30 \\
2.00 \\
2.20 \\
1.90\end{array}$ & $\begin{array}{l}0.40 \\
0.40 \\
0.40 \\
0.40 \\
0.40\end{array}$ \\
\hline $\begin{array}{l}M \\
M 1 \\
M 2 \\
M 3 \\
M 4 \\
M \\
8 \cdot 22 \# 1 C \\
8 \cdot 22 \# 3 C \\
8 \cdot 22 \# 4 C \\
M C 4 D\end{array}$ & $\begin{array}{l}2.30 \\
2.40 \\
2.30 \\
2.00 \\
1.90 \\
2.30 \\
2.50 \\
9.80 \\
2.80 \\
2.00\end{array}$ & $\begin{array}{l}0.40 \\
0.40 \\
0.40 \\
0.40 \\
0.40 \\
0.40 \\
0.40 \\
0.40 \\
0.50 \\
0.40\end{array}$ \\
\hline $\begin{array}{l}\text { \#PSU-CR-1 } \\
+H-2\end{array}$ & $\begin{array}{l}1.70 \\
0.63\end{array}$ & $\begin{array}{l}0.30 \\
0.11\end{array}$ \\
\hline
\end{tabular}


TABLE LXVII

INMA DATA FROM 2ND COUNT FOR CERTAIN ELEMENTS FOLLONED BY ITS ERROR

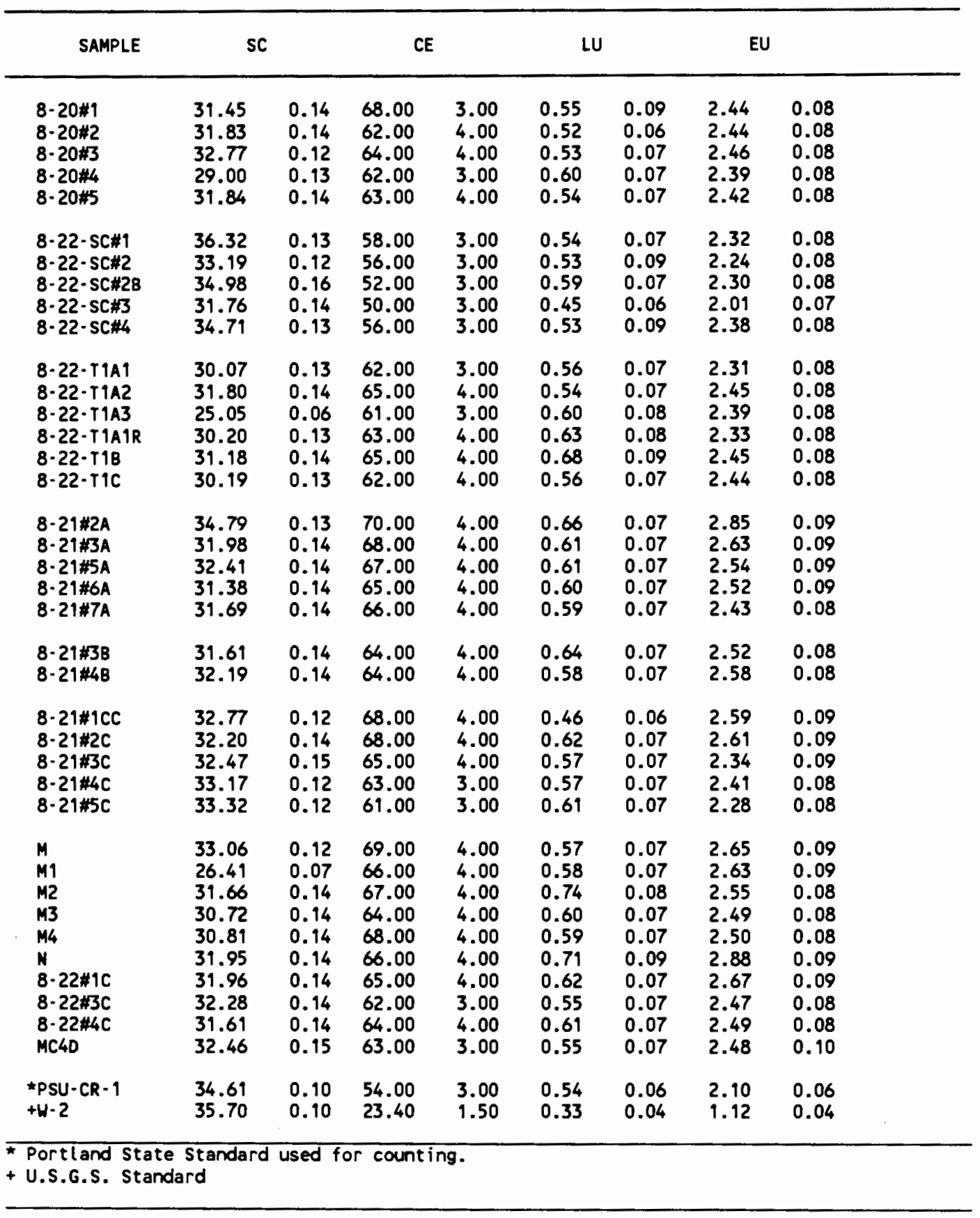


TABLE LXVII CONTINUED

INNA DATA FROM 2ND COUNT FOR CERTAIN ELEMENTS FOLLONED BY ITS ERROR

\begin{tabular}{|c|c|c|c|c|c|c|c|c|}
\hline \multirow{2}{*}{$\begin{array}{c}\text { SAMPLE } \\
8 \cdot 20 \# 1 \\
8-20 \# 2 \\
8-20 \# 3 \\
8 \cdot 20 \# 4 \\
8-20 \# 5\end{array}$} & \multicolumn{2}{|c|}{$\mathrm{HF}$} & \multicolumn{2}{|c|}{ FE } & \multicolumn{2}{|c|}{ TA } & \multicolumn{2}{|c|}{ TB } \\
\hline & $\begin{array}{l}6.60 \\
6.10 \\
6.40 \\
5.70 \\
6.40\end{array}$ & $\begin{array}{l}0.50 \\
0.50 \\
0.50 \\
0.50 \\
0.50\end{array}$ & $\begin{array}{l}11.07 \\
11.62 \\
11.06 \\
10.89 \\
11.68\end{array}$ & $\begin{array}{l}0.09 \\
0.09 \\
0.09 \\
0.09 \\
0.09\end{array}$ & $\begin{array}{l}0.61 \\
0.49 \\
0.54 \\
0.47 \\
0.55\end{array}$ & $\begin{array}{l}0.07 \\
0.07 \\
0.07 \\
0.06 \\
0.07\end{array}$ & $\begin{array}{l}1.60 \\
1.60 \\
1.70 \\
1.70 \\
1.40\end{array}$ & $\begin{array}{l}0.20 \\
0.20 \\
0.30 \\
0.20 \\
0.20\end{array}$ \\
\hline $\begin{array}{l}8-22-S C \# 1 \\
8-22-S C \# 2 \\
8-22-S C \# 2 B \\
8-22-S C \# 3 \\
8-22-S C \# 4\end{array}$ & $\begin{array}{l}5.20 \\
5.20 \\
5.20 \\
5.10 \\
5.40\end{array}$ & $\begin{array}{l}0.50 \\
0.50 \\
0.40 \\
0.40 \\
0.50\end{array}$ & $\begin{array}{l}12.45 \\
12.12 \\
12.73 \\
10.89 \\
11.77\end{array}$ & $\begin{array}{l}0.09 \\
0.10 \\
0.09 \\
0.09 \\
0.10\end{array}$ & $\begin{array}{l}0.49 \\
0.44 \\
0.51 \\
0.29 \\
0.51\end{array}$ & $\begin{array}{l}0.07 \\
0.06 \\
0.07 \\
0.06 \\
0.06\end{array}$ & $\begin{array}{l}1.50 \\
1.40 \\
1.20 \\
1.20 \\
1.30\end{array}$ & $\begin{array}{l}0.20 \\
0.20 \\
0.20 \\
0.20 \\
0.20\end{array}$ \\
\hline $\begin{array}{l}8 \cdot 22-T 1 A 1 \\
8 \cdot 22-T 1 A 2 \\
8-22-T 1 A 3 \\
8 \cdot 22-T 1 A 1 R \\
8-22-T 1 B \\
8-22-T 1 C\end{array}$ & $\begin{array}{l}5.80 \\
6.40 \\
5.80 \\
5.70 \\
6.00 \\
5.70\end{array}$ & $\begin{array}{l}0.50 \\
0.50 \\
0.50 \\
0.50 \\
0.50 \\
0.50\end{array}$ & $\begin{array}{l}11.52 \\
11.78 \\
11.01 \\
11.39 \\
11.27 \\
10.56\end{array}$ & $\begin{array}{l}0.08 \\
0.10 \\
0.09 \\
0.09 \\
0.09 \\
0.08\end{array}$ & $\begin{array}{l}0.46 \\
0.51 \\
0.37 \\
0.52 \\
0.48 \\
0.47\end{array}$ & $\begin{array}{l}0.06 \\
0.07 \\
0.07 \\
0.06 \\
0.07 \\
0.06\end{array}$ & $\begin{array}{l}1.60 \\
1.80 \\
1.60 \\
1.40 \\
1.40 \\
1.60\end{array}$ & $\begin{array}{l}0.20 \\
0.30 \\
0.20 \\
0.20 \\
0.20 \\
0.20\end{array}$ \\
\hline $\begin{array}{l}8-21 \# 2 A \\
8-21 \# 3 A \\
8-21 \# 5 A \\
8-21 \# 6 A \\
8-21 \# 7 A\end{array}$ & $\begin{array}{l}6.80 \\
6.20 \\
6.40 \\
5.90 \\
6.20\end{array}$ & $\begin{array}{l}0.50 \\
0.50 \\
0.50 \\
0.50 \\
0.50\end{array}$ & $\begin{array}{r}8.19 \\
11.63 \\
11.13 \\
10.99 \\
11.63\end{array}$ & $\begin{array}{l}0.07 \\
0.09 \\
0.09 \\
0.09 \\
0.09\end{array}$ & $\begin{array}{l}0.58 \\
0.51 \\
0.53 \\
0.55 \\
0.48\end{array}$ & $\begin{array}{l}0.07 \\
0.07 \\
0.07 \\
0.07 \\
0.07\end{array}$ & $\begin{array}{l}1.70 \\
1.50 \\
1.70 \\
1.70 \\
1.40\end{array}$ & $\begin{array}{l}0.20 \\
0.20 \\
0.20 \\
0.20 \\
0.20\end{array}$ \\
\hline $\begin{array}{l}8 \cdot 21 \# 3 B \\
8 \cdot 21 \# B B\end{array}$ & $\begin{array}{l}6.20 \\
6.50\end{array}$ & $\begin{array}{l}0.50 \\
0.50\end{array}$ & $\begin{array}{l}11.26 \\
11.54\end{array}$ & $\begin{array}{l}0.09 \\
0.09\end{array}$ & $\begin{array}{l}0.47 \\
0.39\end{array}$ & $\begin{array}{l}0.07 \\
0.07\end{array}$ & $\begin{array}{l}1.60 \\
1.90\end{array}$ & $\begin{array}{l}0.20 \\
0.30\end{array}$ \\
\hline $\begin{array}{l}8-21 \# 1 C C \\
8-21 \# 2 C \\
8-21 \# 3 C \\
8-21 \# 4 C \\
8-21 \# 5 C\end{array}$ & $\begin{array}{l}6.30 \\
6.30 \\
5.70 \\
6.10 \\
5.90\end{array}$ & $\begin{array}{l}0.50 \\
0.50 \\
0.50 \\
0.50 \\
0.50\end{array}$ & $\begin{array}{r}9.48 \\
11.65 \\
11.93 \\
12.08 \\
11.76\end{array}$ & $\begin{array}{l}0.08 \\
0.09 \\
0.10 \\
0.09 \\
0.09\end{array}$ & $\begin{array}{l}0.52 \\
0.49 \\
0.43 \\
0.51 \\
0.34\end{array}$ & $\begin{array}{l}0.07 \\
0.07 \\
0.06 \\
0.07 \\
0.07\end{array}$ & $\begin{array}{l}1.50 \\
1.70 \\
1.50 \\
1.40 \\
1.60\end{array}$ & $\begin{array}{l}0.20 \\
0.20 \\
0.20 \\
0.20 \\
0.20\end{array}$ \\
\hline $\begin{array}{l}M \\
M 1 \\
M 2 \\
M 3 \\
M 4 \\
M \\
8 \cdot 22 \# 1 C \\
8-22 \# 3 C \\
8 \cdot 22 \# 4 C \\
M C 4 D\end{array}$ & $\begin{array}{l}6.40 \\
6.60 \\
6.50 \\
6.00 \\
6.30 \\
6.60 \\
6.50 \\
6.20 \\
6.20 \\
5.90\end{array}$ & $\begin{array}{l}0.50 \\
0.50 \\
0.50 \\
0.50 \\
0.50 \\
0.50 \\
0.50 \\
0.50 \\
0.50 \\
0.50\end{array}$ & $\begin{array}{l}10.45 \\
11.82 \\
11.29 \\
11.16 \\
11.49 \\
10.67 \\
11.56 \\
11.03 \\
11.30 \\
11.60\end{array}$ & $\begin{array}{l}0.08 \\
0.10 \\
0.09 \\
0.09 \\
0.09 \\
0.09 \\
0.09 \\
0.09 \\
0.09 \\
0.09\end{array}$ & $\begin{array}{l}0.54 \\
0.55 \\
0.51 \\
0.36 \\
0.54 \\
0.53 \\
0.50 \\
0.49 \\
0.49 \\
0.46\end{array}$ & $\begin{array}{l}0.07 \\
0.07 \\
0.07 \\
0.07 \\
0.07 \\
0.07 \\
0.07 \\
0.06 \\
0.07 \\
0.06\end{array}$ & $\begin{array}{l}1.80 \\
1.50 \\
1.50 \\
1.70 \\
1.60 \\
2.20 \\
1.80 \\
1.50 \\
1.60 \\
1.60\end{array}$ & $\begin{array}{l}0.30 \\
0.20 \\
0.20 \\
0.20 \\
0.20 \\
0.30 \\
0.30 \\
0.20 \\
0.20 \\
0.20\end{array}$ \\
\hline $\begin{array}{l}8 P S U-C R-1 \\
+W-2\end{array}$ & $\begin{array}{l}5.20 \\
2.60\end{array}$ & $\begin{array}{l}0.40 \\
0.20\end{array}$ & $\begin{array}{r}12.21 \\
9.03\end{array}$ & $\begin{array}{l}0.07 \\
0.05\end{array}$ & $\begin{array}{l}0.41 \\
0.52\end{array}$ & $\begin{array}{l}0.04 \\
0.04\end{array}$ & $\begin{array}{l}1.27 \\
0.66\end{array}$ & $\begin{array}{l}0.17 \\
0.10\end{array}$ \\
\hline
\end{tabular}


TABLE LXVII CONTINUED

INNA DATA FROM 2ND COUNT FOR CERTAIN ELEMENTS FOLLOWED BY ITS ERROR

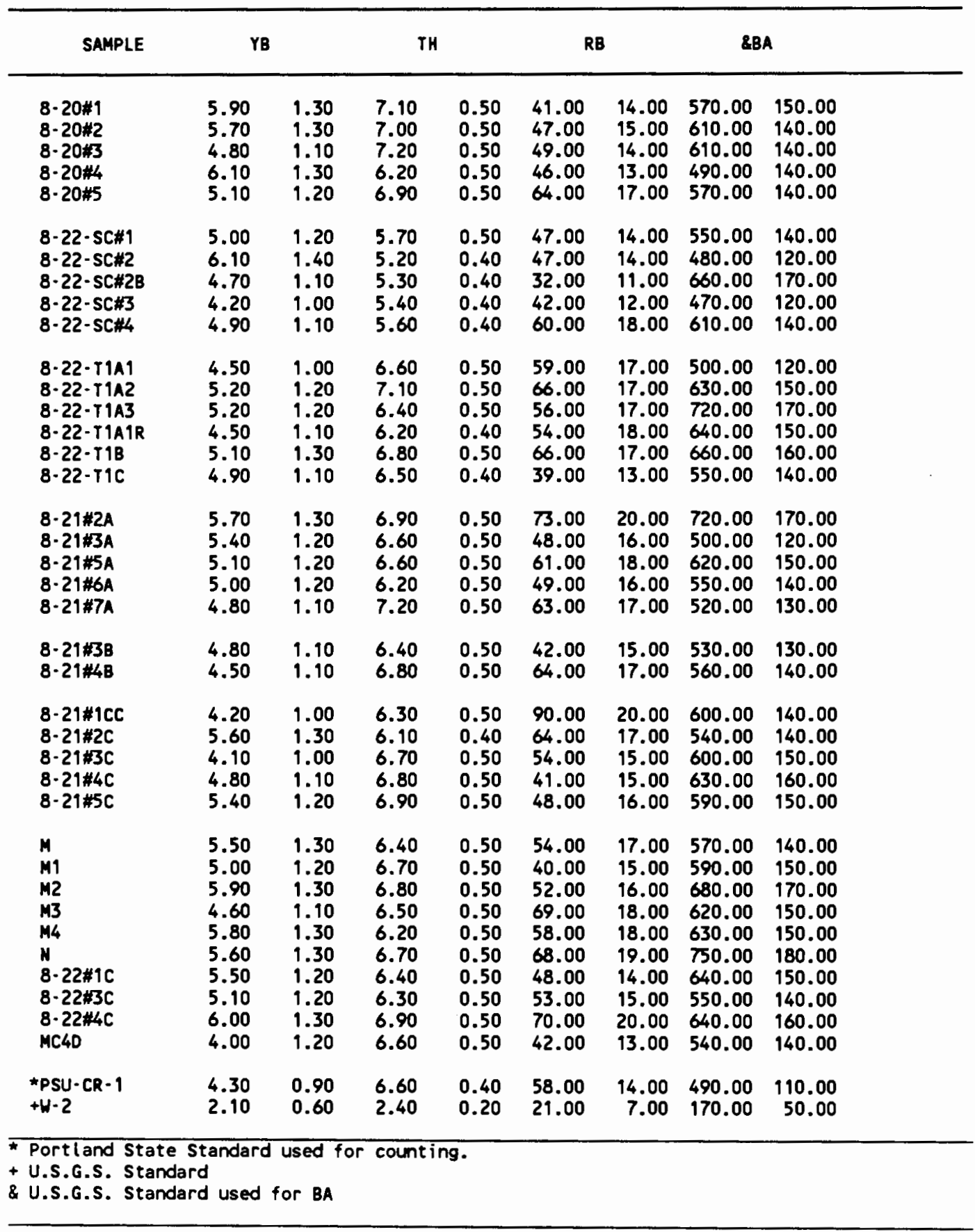


TABLE LXVII CONTINUED

INNA DATA FROM 2ND COUNT FOR CERTAIN ELEMENTS FOLLONED BY ITS ERROR

\begin{tabular}{|c|c|c|}
\hline SAMPLE & SBA & \\
\hline $\begin{array}{l}8-20 \# 1 \\
8-20 \# 2 \\
8-20 \# 3 \\
8-20 \# 4 \\
8-20 \# 5\end{array}$ & $\begin{array}{l}820.00 \\
830.00 \\
900.00 \\
820.00 \\
770.00\end{array}$ & $\begin{array}{l}130.00 \\
120.00 \\
130.00 \\
120.00 \\
140.00\end{array}$ \\
\hline $\begin{array}{l}8-22 \cdot S C \# 1 \\
8-22-S C \# 2 \\
8-22-S C \# 2 B \\
8-22 \cdot S C \# 3 \\
8-22-S C \# 4\end{array}$ & $\begin{array}{l}690.00 \\
590.00 \\
870.00 \\
670.00 \\
820.00\end{array}$ & $\begin{array}{l}110.00 \\
100.00 \\
120.00 \\
110.00 \\
120.00\end{array}$ \\
\hline $\begin{array}{l}8-22-T 1 A 1 \\
8-22-T 1 A 2 \\
8-22-T 1 A 3 \\
8-22-T 1 A 1 R \\
8-22-T 1 B \\
8-22-T 1 C\end{array}$ & $\begin{array}{l}770.00 \\
850.00 \\
900.00 \\
840.00 \\
820.00 \\
720.00\end{array}$ & $\begin{array}{l}110.00 \\
120.00 \\
120.00 \\
130.00 \\
110.00 \\
110.00\end{array}$ \\
\hline $\begin{array}{l}8-21 \# 2 A \\
8-21 \# 3 A \\
8-21 \# 5 A \\
8-21 \# 6 A \\
8-21 \# 7 A\end{array}$ & $\begin{array}{l}940.00 \\
730.00 \\
780.00 \\
720.00 \\
670.00\end{array}$ & $\begin{array}{l}130.00 \\
120.00 \\
190.00 \\
110.00 \\
110.00\end{array}$ \\
\hline $\begin{array}{l}8 \cdot 21 \$ 3 B \\
8-21 \# 4 B\end{array}$ & $\begin{array}{l}750.00 \\
750.00\end{array}$ & $\begin{array}{l}110.00 \\
140.00\end{array}$ \\
\hline $\begin{array}{l}8-21 \# 1 c c \\
8-21 \# 2 c \\
8-21 \# 3 c \\
8-21 \# 4 c \\
8-21 \# 5 c\end{array}$ & $\begin{array}{l}790.00 \\
770.00 \\
750.00 \\
750.00 \\
830.00\end{array}$ & $\begin{array}{l}130.00 \\
120.00 \\
110.00 \\
130.00 \\
120.00\end{array}$ \\
\hline $\begin{array}{l}M \\
M 1 \\
M 2 \\
M 3 \\
M 4 \\
N \\
8-22 \# 1 C \\
8-22 \# 3 C \\
8-22 \# 4 C \\
M C 40\end{array}$ & $\begin{array}{l}800.00 \\
780.00 \\
870.00 \\
820.00 \\
830.00 \\
920.00 \\
800.00 \\
760.00 \\
780.00 \\
720.00\end{array}$ & $\begin{array}{l}120.00 \\
120.00 \\
130.00 \\
120.00 \\
120.00 \\
160.00 \\
120.00 \\
140.00 \\
150.00 \\
110.00\end{array}$ \\
\hline $\begin{array}{l}\text { सPSU-CR-1 } \\
+H-2\end{array}$ & $\begin{array}{l}670.00 \\
240.00\end{array}$ & $\begin{array}{r}100.00 \\
60.00\end{array}$ \\
\hline \multicolumn{3}{|c|}{$\begin{array}{l}\text { * Portland State Standard used for counting. } \\
+ \text { U.S.G.S. Standard } \\
\text { Portlan State Standard used for BA }\end{array}$} \\
\hline
\end{tabular}


TABLE XII

XRF DATA FOR CERTAIN ELEMENTS

\begin{tabular}{|c|c|c|c|c|c|c|c|}
\hline SAMPLE & $\mathrm{SiO}_{2}$ & $\mathrm{Al}_{2} \mathrm{O}_{3}$ & $\mathrm{TiO}_{2}$ & $\mathrm{Fe}_{2} \mathrm{O}_{3}$ & FeO & Mno & $\mathrm{CaO}$ \\
\hline $\begin{array}{l}N \\
M 4 \\
M\end{array}$ & $\begin{array}{l}56.90 \\
56.22 \\
57.02\end{array}$ & $\begin{array}{l}15.90 \\
15.29 \\
15.76\end{array}$ & $\begin{array}{l}2.69 \\
2.55 \\
2.63\end{array}$ & $\begin{array}{l}2.00 \\
2.00 \\
2.00\end{array}$ & $\begin{array}{r}10.39 \\
10.98 \\
9.49\end{array}$ & $\begin{array}{l}0.14 \\
0.18 \\
0.19\end{array}$ & $\begin{array}{l}5.25 \\
5.37 \\
5.55\end{array}$ \\
\hline $\begin{array}{l}8-21 \# 7 A \\
8-21 \# 6 A \\
8-21 \# 5 A \\
8-21 \# 3 A \\
8-21 \# 2 A\end{array}$ & $\begin{array}{l}55.63 \\
55.67 \\
56.25 \\
55.78 \\
58.55\end{array}$ & $\begin{array}{l}15.08 \\
15.25 \\
15.30 \\
15.08 \\
16.55\end{array}$ & $\begin{array}{l}2.46 \\
2.57 \\
2.61 \\
2.52 \\
2.87\end{array}$ & $\begin{array}{l}2.00 \\
2.00 \\
2.00 \\
2.00 \\
2.00\end{array}$ & $\begin{array}{r}10.26 \\
9.84 \\
10.06 \\
10.25 \\
7.94\end{array}$ & $\begin{array}{l}0.17 \\
0.18 \\
0.18 \\
0.21 \\
0.31\end{array}$ & $\begin{array}{l}6.14 \\
6.40 \\
5.75 \\
6.10 \\
4.56\end{array}$ \\
\hline $\begin{array}{l}8-22 \# 4 C \\
8 \cdot 22 \# 3 C\end{array}$ & $\begin{array}{l}56.34 \\
55.84\end{array}$ & $\begin{array}{l}15.15 \\
15.16\end{array}$ & $\begin{array}{l}2.48 \\
2.49\end{array}$ & $\begin{array}{l}2.00 \\
2.00\end{array}$ & $\begin{array}{l}9.96 \\
9.94\end{array}$ & $\begin{array}{l}0.23 \\
0.24\end{array}$ & $\begin{array}{l}6.01 \\
6.39\end{array}$ \\
\hline
\end{tabular}

\begin{tabular}{lllll}
\hline \multicolumn{1}{c}{ SAMPLE } & $M g O$ & $K_{2} \mathrm{O}$ & $\mathrm{Na}_{2} \mathrm{O}$ & $\mathrm{P}_{2} \mathrm{O}_{5}$ \\
\hline $\mathrm{N}$ & 1.93 & 2.07 & 2.22 & 0.51 \\
$M 4$ & 2.56 & 2.04 & 2.39 & 0.43 \\
$M$ & 2.35 & 2.04 & 2.48 & 0.49 \\
$8-21 \# 7 \mathrm{~A}$ & 3.48 & 1.79 & 2.54 & 0.44 \\
$8-21 \# 6 \mathrm{~A}$ & 3.08 & 1.94 & 2.59 & 0.48 \\
$8-21 \# 5 \mathrm{~A}$ & 2.84 & 2.10 & 2.41 & 0.48 \\
$8-21 \# 3 \mathrm{~A}$ & 3.36 & 1.80 & 2.45 & 0.47 \\
$8-21 \# 2 \mathrm{~A}$ & 1.29 & 2.90 & 2.49 & 0.57 \\
$8-22 \# 4 \mathrm{C}$ & 2.64 & 2.20 & 2.51 & 0.48 \\
$8-22 \# 3 \mathrm{C}$ & 3.19 & 1.85 & 2.48 & 0.42 \\
& & & & \\
\hline Analyzed at Washington State University by P. R. Hooper, 1986. \\
\hline
\end{tabular}


APPENDIX E

DEFINITIONS 
Basaltic arm is a single layer of basalt separated by joint traces and collectively with other layers form the confining walls of an explosion structure.

Brecciated flows are flows containing explosion structures at a stratigraphic section site and generally consist of two cooling units .

Breciated flow areas consist of the areas within the same flow where explosion structures are located and immediate adjacent of the same flow that were effective by the formation of explosion structures (both cooling units) (Figure 3 ). Confining walls are the collection of jointed basalt layers that form an nested arch of an explosion structure. Individual layer are composed of different textured basalt and textures range from vitrophyric to intergranular.

Explosion structures consist of confining walls that form nested arches that surround a steeply dipping breccia spine and vesicular clasts/pockets intraflow zones. The confining walls are composed of banded textures of basalt that are separated by joint traces.

Nonbrecciated flow areas are areas in the same flow that are located between nearby explosion structures (Figure 3 ). Unbrecclated flows are flows lacking explosion structures within the flow at a stratigraphic section sites and typically consist of a single cooling unit (Figure 3 ).

Unbrecciated flow areas are areas within the same flow that lack nearby explosion structures completely. 
APPENDIX F

SUMMARY OF FIELD AND LABORATORY TECHNIQUES 
TABLE LXIX

DETAILED SUMMARY OF FIELD TECHMIQUES AMD EOUIPMENT

\begin{tabular}{lcc}
\hline $\begin{array}{l}\text { Operation or } \\
\text { Measurement }\end{array}$ & $\begin{array}{c}\text { Equipment } \\
\text { Used }\end{array}$ & Comments on Process \\
\hline
\end{tabular}

plotting

sample numbering

flow sampling

elevations

strike, dips,

stratigraphic measured section

horizontal and vertical transverses

Counting of breccia clasts and clasts/pockets
$71 / 2$ minute topographic quadrangles

rock hammer

Model M-1 "Micro" surveying altimeter

Brunton compass

Model M- 1 altimeter and hammer

100 foot tape

100 foot tape or

4 bu 4 foot square grid
Portions of Troy, Eden Flora, Saddle Mountain, Mountain View, Diamond Peak, and Field Spring quadrangles.

Samples were prefixed either by date, location, or letters.

Samples were taken at key field locations and freshest possible rock was taken.

Large altimeter used primarily for measured and collection of both rock samples and stratigraphic stratigraphic. Altimeter was calibrated at U.S.G.S. benchmarks before and after use.

Used primarily for structures breccia trends of the plane of bearing the steeply dipping breccia.

Elevations of both the superjacent and subjacent contacts were investigated and measured by the $M-1$ altimeter. Jointing, vesicles, vesicular or scoriaceous zones, morphological profile and subjacent basal behavior were recorded in the field notes. If an explosion structure was being measured, the breccia and compact intervals were measured for each brecciated flow.

The tape was stretched across an explosion structure exposure and the three different regions of rock were measured and significant remarks were recorded as field notes (Appendix C).

Distribution of clast types was found by using two different methods: 1) line method used a 100 foot tape wich was stretch across an outcrop and 2) a square wooden grid was placed on the outcrop at particular points along the tape or a succession of horizontal intervals covering the width of an outcrop. Each outcrop was selected, because the outcrop face lacked extensive litchen coverage, was occessable, and safe since the best exposures were on steep slopes. The line method was used in conjunction with the measurement of the three regions of rock types of an explosion structure (Appendix C). A clasts was counted when the tape concided with its position on the rock face and its width was measured. 
TABLE LXX

DETAILED SUMMARY OF LABORATORY TECHNIQUES AND EQUIPMENT

\begin{tabular}{|c|c|c|}
\hline $\begin{array}{l}\text { Operation or } \\
\text { Measurement }\end{array}$ & $\begin{array}{l}\text { Equipment } \\
\text { Used }\end{array}$ & Comments \\
\hline INAA & $\begin{array}{l}\text { INAA equipment: balance, plastic vials, } \\
\text { etc. }\end{array}$ & $\begin{array}{l}\text { Preparation used has been } \\
\text { learned from G } 501 \\
\text { Advanced Geochemistry. }\end{array}$ \\
\hline XRF & send to Hooper at Washington st. University & $\begin{array}{l}\text { Same chips, but a } \\
\text { different split. }\end{array}$ \\
\hline Mossbauer & Don Howard PSU Physics Dept. & $\begin{array}{l}\text { Powdered splits from } \\
\text { remaining splits left over } \\
\text { from INAA process. }\end{array}$ \\
\hline Thin section & send out to Rockwell, Richland UA & Polished sections. \\
\hline Modal Analys is & Zweiss microscope & $\begin{array}{l}1,000 \text { counts per thin } \\
\text { section. }\end{array}$ \\
\hline Textures: grain sizes & Zweiss microscope with ocular micrometer & \\
\hline Optical measurements & Zwe iss microscope & $\begin{array}{l}\text { Optical angles were done } \\
\text { for proxenes by direct } \\
\text { rotation }\end{array}$ \\
\hline Plagioclase An content & Zweiss microscope & $\begin{array}{l}\text { Michel-Levy method for } \\
\text { phenocrysts, microphenos } \\
\text { and for microltic } \\
\text { plagioclase. }\end{array}$ \\
\hline
\end{tabular}


APPENDIX G

SUMMARY OF STATISTICAL ANALYSIS OF GEOCHEMICAL DATA 
TABLE LXXI

INDIVIOUAL VARIANCES FOR EACH ELEMENT

\begin{tabular}{|c|c|c|c|}
\hline Elements & $\begin{array}{l}\text { Variances for } \\
\text { Grouse Creek (GC) }\end{array}$ & $\begin{array}{l}\text { Variances for } \\
\text { Wenahe Ravine (UR) }\end{array}$ & $\begin{array}{l}f \text {-test } \\
\text { value }\end{array}$ \\
\hline LA & 2.43524 & 6.88557 & 2.83 \\
\hline CE & 9.50000 & 7.20000 & 1.32 \\
\hline SM & 0.12264 & 0.65628 & 5.35 \\
\hline EU & 0.02193 & 0.02745 & 1.25 \\
\hline TB & 0.01300 & 0.08700 & 6.69 \\
\hline YB & 0.46200 & 0.09700 & 4.76 \\
\hline LU & 0.00398 & 0.00763 & 1.92 \\
\hline BA & 1370.00000 & 380.00000 & 3.61 \\
\hline co & 34.30000 & 18.30000 & 1.87 \\
\hline FE & 1.15498 & 0.18389 & 6.28 \\
\hline K & 0.09700 & 0.06200 & 1.56 \\
\hline HF & 0.06799 & 0.02500 & 2.72 \\
\hline NA & 0.00048 & 0.02088 & 43.50 \\
\hline RB & 309.19995 & 43.00000 & 7.19 \\
\hline sc & 0.25227 & 0.68120 & 2.70 \\
\hline TA & 0.00557 & 0.00047 & 11.85 \\
\hline TH & 0.11800 & 0.06699 & 1.76 \\
\hline $\begin{array}{l}\text { Degrees of freedom } \\
\text { The critical value } \\
6.00 \text { for Wehana Rav }\end{array}$ & $\begin{array}{l}\text { Creek is 4, while } \\
\text { est with a } 0.05 \text { si }\end{array}$ & $\begin{array}{l}\text { reedom for Wenaha } \\
3.63 \text { for Grouse }\end{array}$ & 9. \\
\hline
\end{tabular}

